Historic, Archive Document

Do not assume content reflects current scientific knowledge, policies, or practices. 



\subsection{1}

TIAEARS

SEEE REPORT:WE 8EAT ATE.

NOV I \& 1924

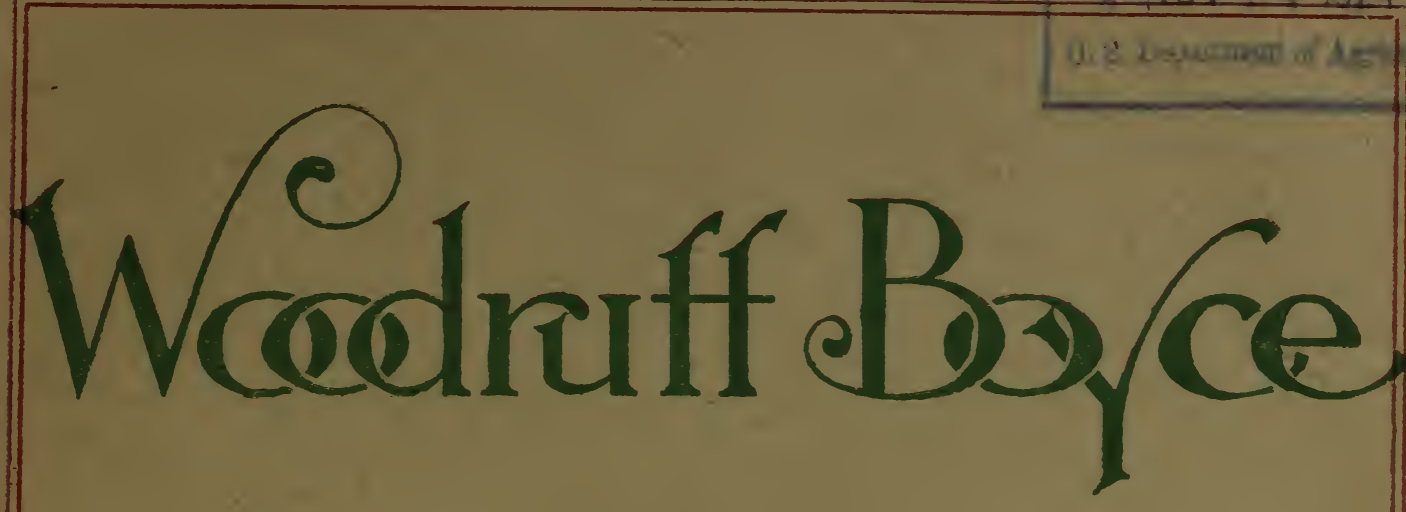

A N NU A L

1920

VEGETABLE, FIELD, FLOWER AND

GARDEN SEED

NURSERY STOCK

ORNAMENTAL SHRUBS

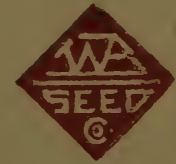

WOODRUFF- BOYCE

89 Pike Street

SEATTLE 


\section{Our Special $\$ 1.00$ Collection of}

\section{SWEET PEAS}

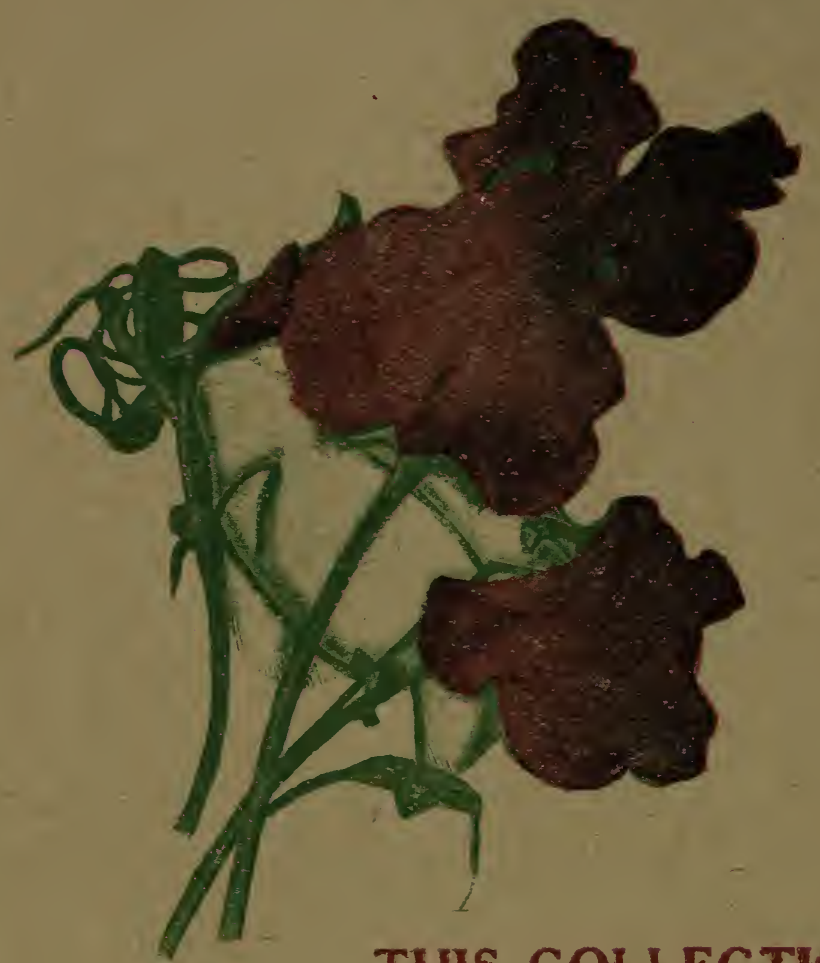

We are offering this year a very choice collection of ten different colored

\section{SWEET PEAS}

which at the regular price would cost you $\$ 2.00$.

\section{$\$ 1.00$}

Our Special Offer

$\$ 1.00$

THIS COLLECTION

consists of the following varieties:

DOBIE'S CREAM

Pest cream Spencer

WEDGEWOOD

Porcelain Blue

ILLUMINATOR

Brilliant salmon cerise

KING EDWARD VII

Best red

KING WHITE

Best pure white
MARGARET ATLEE

Best deep cream pink MARION BEAVER

Best light cream pink ORCHID

Best lavender

ROBERT SYDENHAM

Orange

ROYAL PURPLE

A rich deep purple

We have a special NTH PEAS. By its use NIII GN you are certain to increase the size and the brilliancy of the bloom and the length of stem. Price 30 cents. 


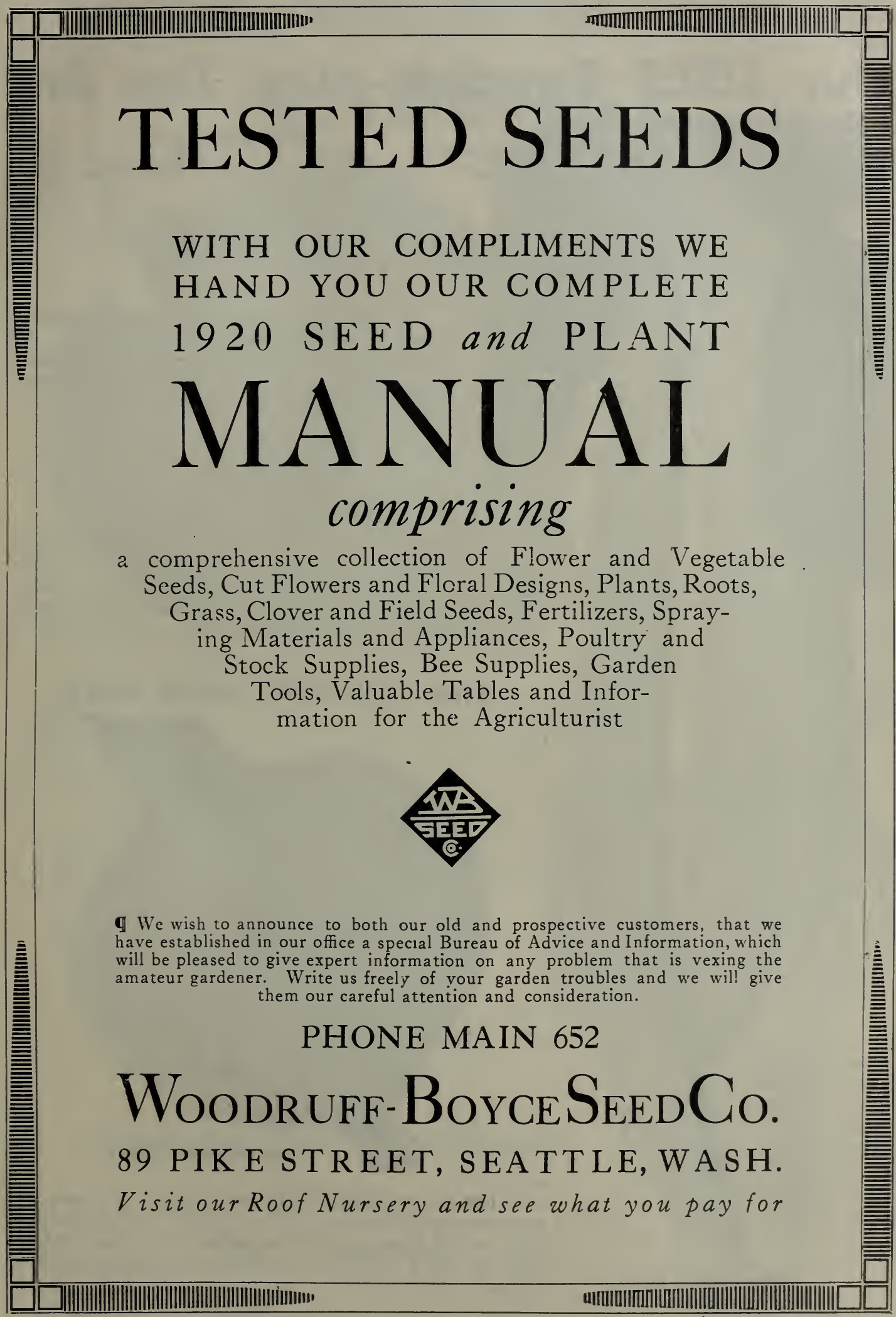




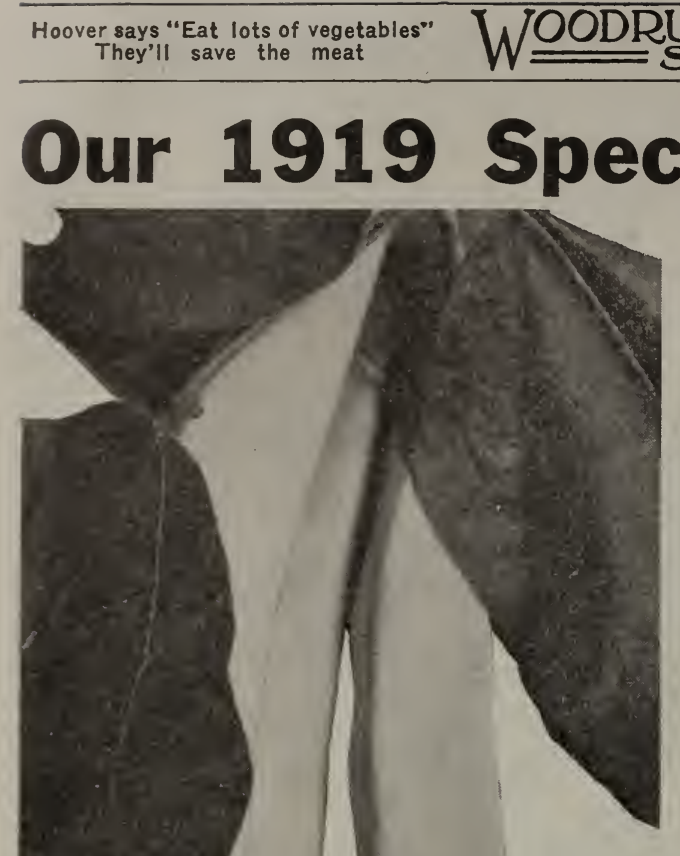

\section{Our 1919 Specials-Look Them Over \\ ASPARAGUS Extra Early Palmetto}

Larger, earlier, more uniform in size; more prolific and disease-resisting than any other Asparagus grown. Seeds, pkt. 10c, oz. 25c, 1 lb. $\$ 1.00$.

We would suggest that you purchase two-year-old plants of this variety ; in this way you get away from the trouble of raising and gain two years in the growing. Doz. 50c, 100 for $\$ .300$.

\section{WAX BEAN Washington Davis}

An unrivaled Wax Dwarf or Bush Bean grown locally and the earliest wax podded variety we have. Symmetrical in shape, stringless, prolific, attractive color and a favorite with the gardeners. It is thoroughly acclimated and it is our opinion that it will be quite a favorite. Pkt., 10c; lb., 35c, postpaid.

\section{FINE CRIMSON GLOBE BEET}

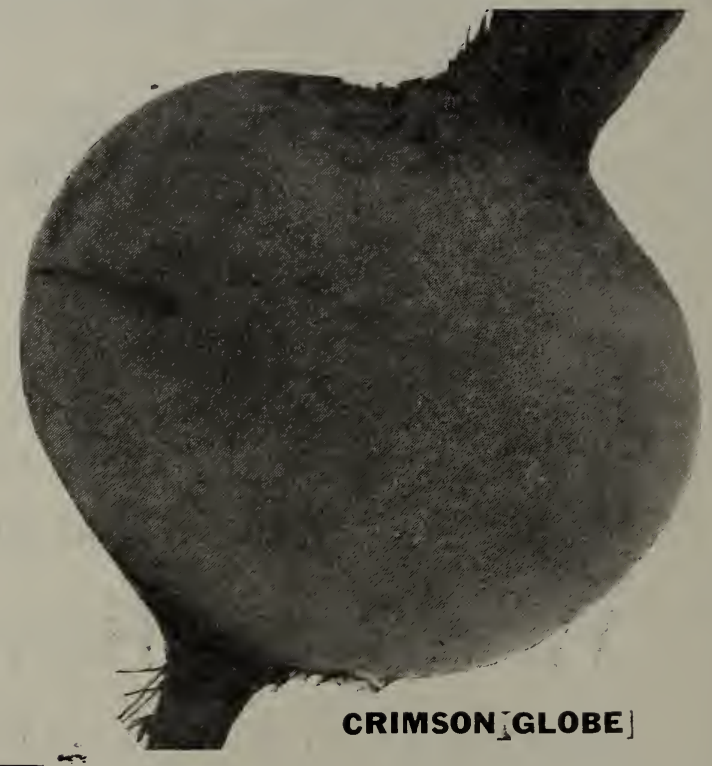

This is a local grown seed and is a consistent producer of early wax beans. An excellent bean to can.

A fine shaped beet that is very popular amongst the gardeners in all sections of the country. It is medium size, with a smooth and even surface. The flesh is deep crimson and a fine color, tender and fine flavored when cooked. Pkt., 10c; 1 oz., 20c; $\frac{1}{4}$ lb., 50c; 1 lb., $\$ 1.50$. 


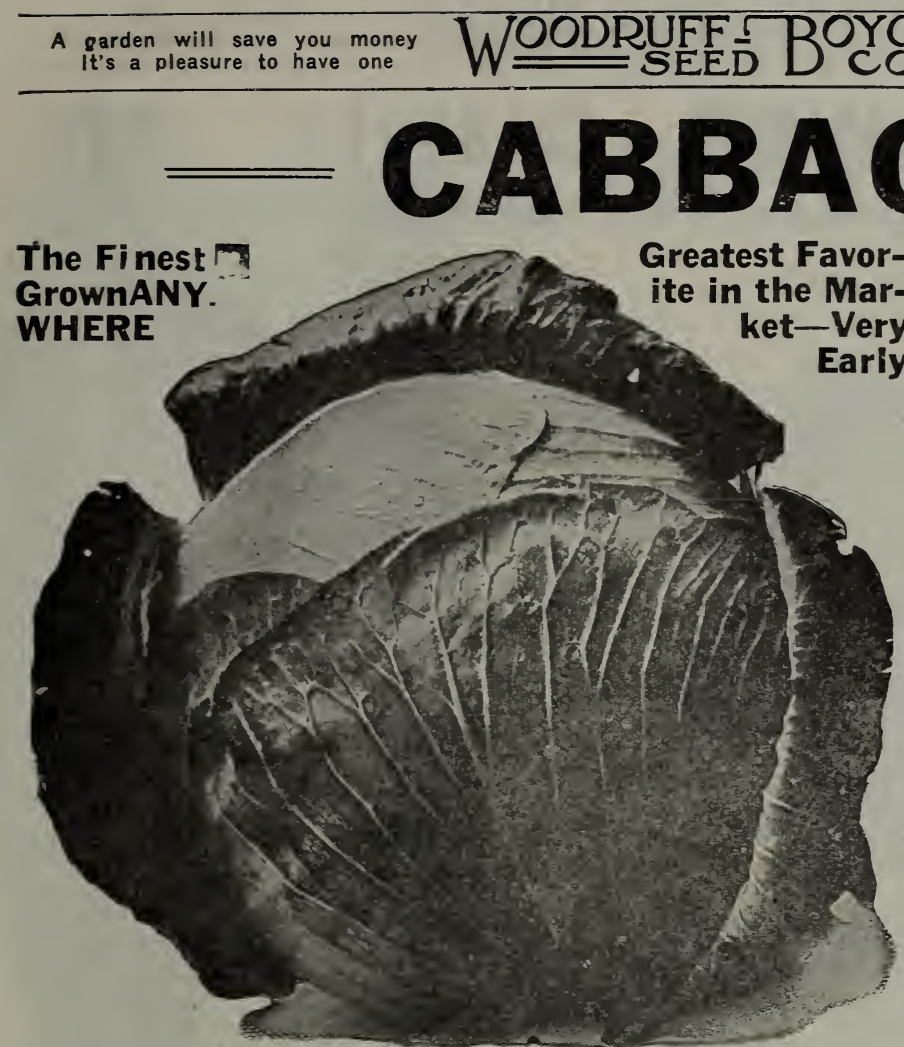

\section{COPENHAGEN MARKET}

Sold under a variety of names, but the original stock is unexcelled for an early, round-headed cabbage. It is the earliest of its shape, exceptionally large and heads uniform; has a short. stem and but few outer leaves. It is recommended for the house and market gardeners' use. Pkt., $10 \mathrm{c}$; oz., 50c 1-quarter lb., $\$ 1.50$.

\section{DANISH BALL HEAD CABBAGE}

Selected stock seed, needs very little introduction, but it can't be beat for late cabbage. A fine keeper, heads large, solid, and when trimmed weighs at least onequarter more than any other cabbage its size. Pkt., 10c; oz., 50c; 1-quarter lb., \$1.50.

\section{For Prices and}

Culture of

\section{Cabbage and Cauliflower \\ Plants See Page 33}

\section{An Importation of Great Merit. Try It.}

The culture for Chinese Cabbage is the same as for Winter Cabbage. The seed should be sown in July or early August, and early in September the plants should be transplanted. They should be set one foot apart in the row and pushed down one and one-half inches in the ground. When well grown the plants should be blanched by tying closely with burlap. Any good soil is sufficient, but they seem to head up best on rich black adobe soil.

This is an importation from China that is greatly relished by most Americans. It was formerly only to be oidtained from the Chinese gardener, but on account of the popular demand for it, is now grown by most of the progressive gardeners on the coast. It is cooked as greens, being tender and succulent and very delicious. Pkt., 10c; oz., 30c; 1-quarter lb., \$1.00. 


\section{All of our seeds are tested \\ CAULIFLOWER}

SNOWBALL_Par Excellent

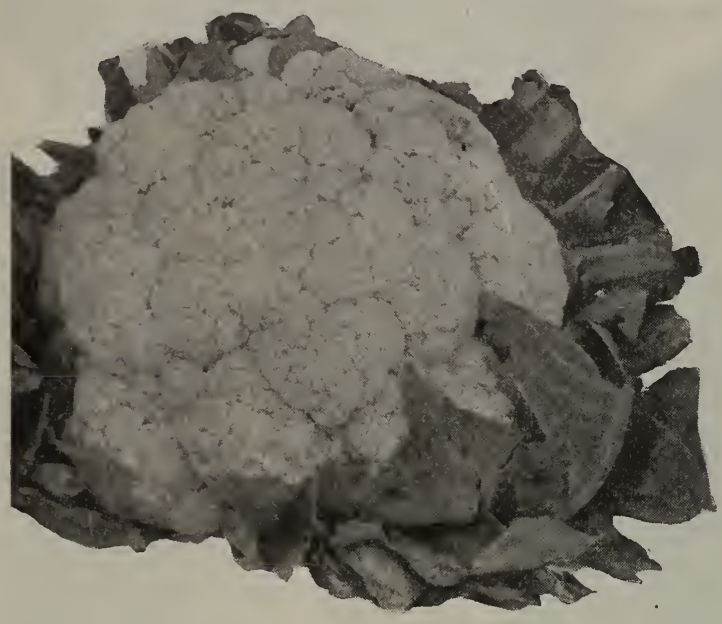

The demand for this seed with us is enormous, because the market gardeners have found out that our selected strain of Danish Snowball seed is as good as can be had. There is none its equal by reason of its compact, upright habit, quick growth and sure heading quality. This is not a summer or dry weather variety and must be sown early to get the best results. Pkt., 25c; 1-quarter oz., 75c; oz., $\$ 2.00$.

\section{CELERY}

GOLDEN, SELF-BLANCHING

Stalks, thick, crisp and brittle. Blanches a beautiul waxen yellow. An excellent variety of French origin.

This is the variety grown largely for market, but it is equally valuable for the private garden. It is very early, blanches quickly and its rich color makes it quite attractive. The habit of the plant is short and stocky; the stalks are broad, thick and very solid. It develops a large heart quite early in its growth, which makes the greater part of the plant edible. It is fit for use early in September, and remains in use until the later winter sorts mature. Pkt., 10c; 1quarter oz., 35c; oz., \$1.00.

\section{CELERY PLANTS}

White Plume and Golden Self-blanching, during May, June and July.
CARROTS CHANTENAY

\section{A Rich Bright Orange Carrot}

We have always specialized on this particular carrot and have always used a selected strain of imported seed, thus assuring the rich, bright orange colored, juicy, sweet, crisp carrot much unlike the tough variety that is so common. It is a half-long variety, broad at the neck and tapers to a blunt base. Pkt., 10c; oz., 20c; 1-quarter lb., $50 \mathrm{c} ; 1$ lb., $\$ 1.50$.

Parisian-or French forcing; extremely early, a small round carrot, sweet, tender and an excellent table variety. Pkt., $10 \mathrm{c}$; oz., 20c; 1-quarter lb., 40c; $1 \mathrm{lb}$., $\$ 1.00$.
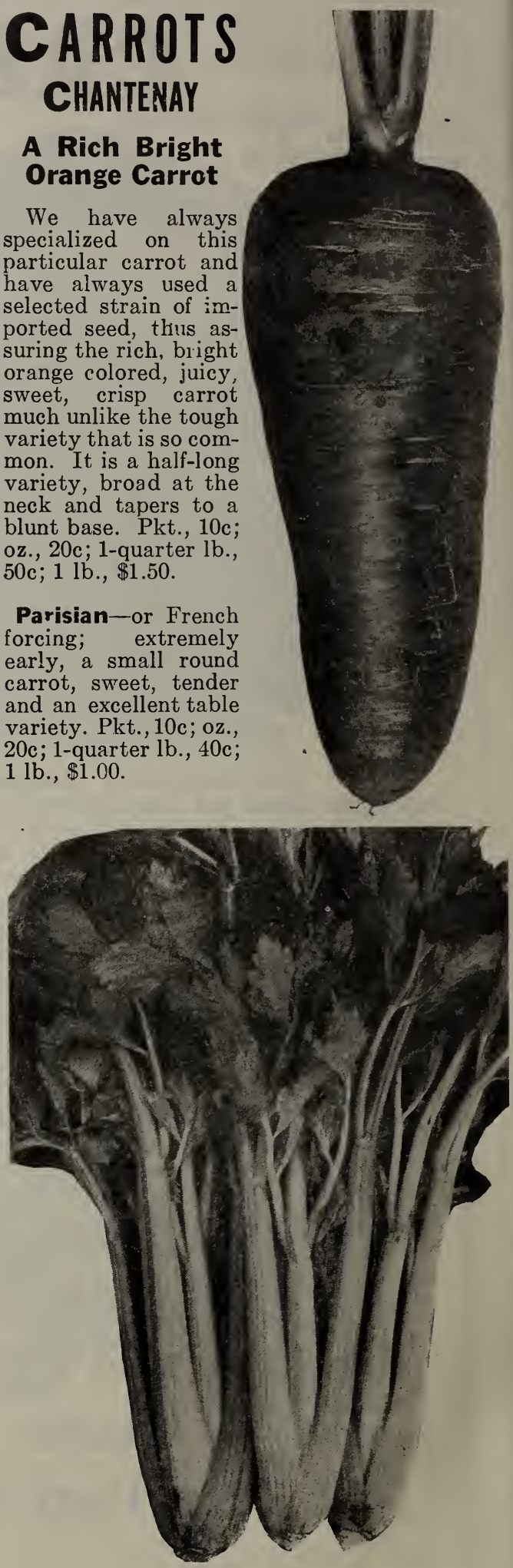


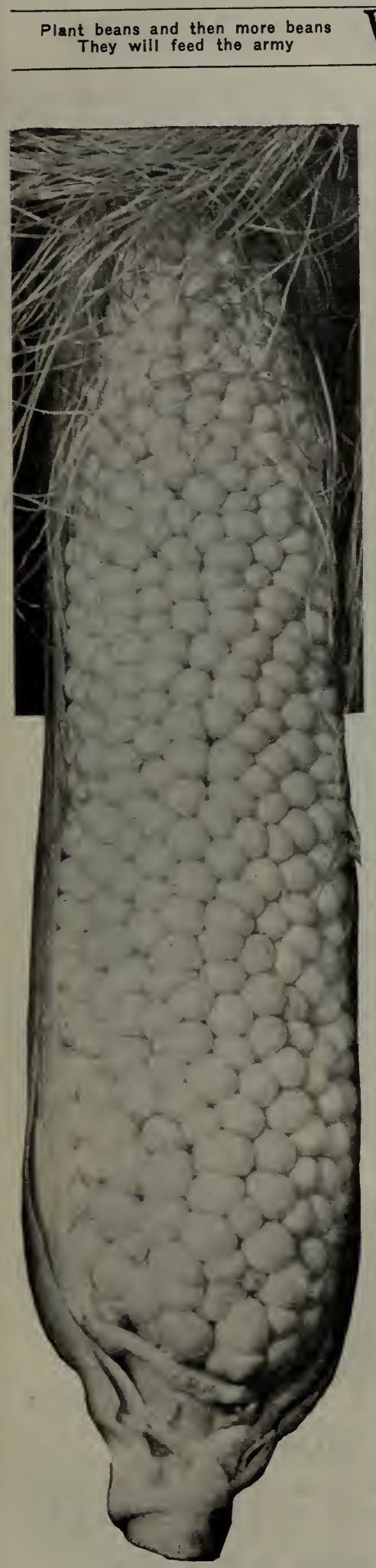

\section{CDTwo of the Most Popular Va- rieties for Table Use. : : :}

\section{GOLDEN BANTAM}

Our stock will be the same selected strain we always have and it can't be beat for a garden corn. For sweetness or yield these two varieties will give you corn all season. Pkt., 15c; 1 lb., 35c.

\section{GOLDEN CREAM}

This is the most delicious sweet corn known, large ears, luscious, tender and milky, and remains "in the milk" longer than any other variety. Resembles the Golden Bantam in color but is a late variety and a fine one to end the season with. Pkt., 15c; 1 lb., 35̃c.

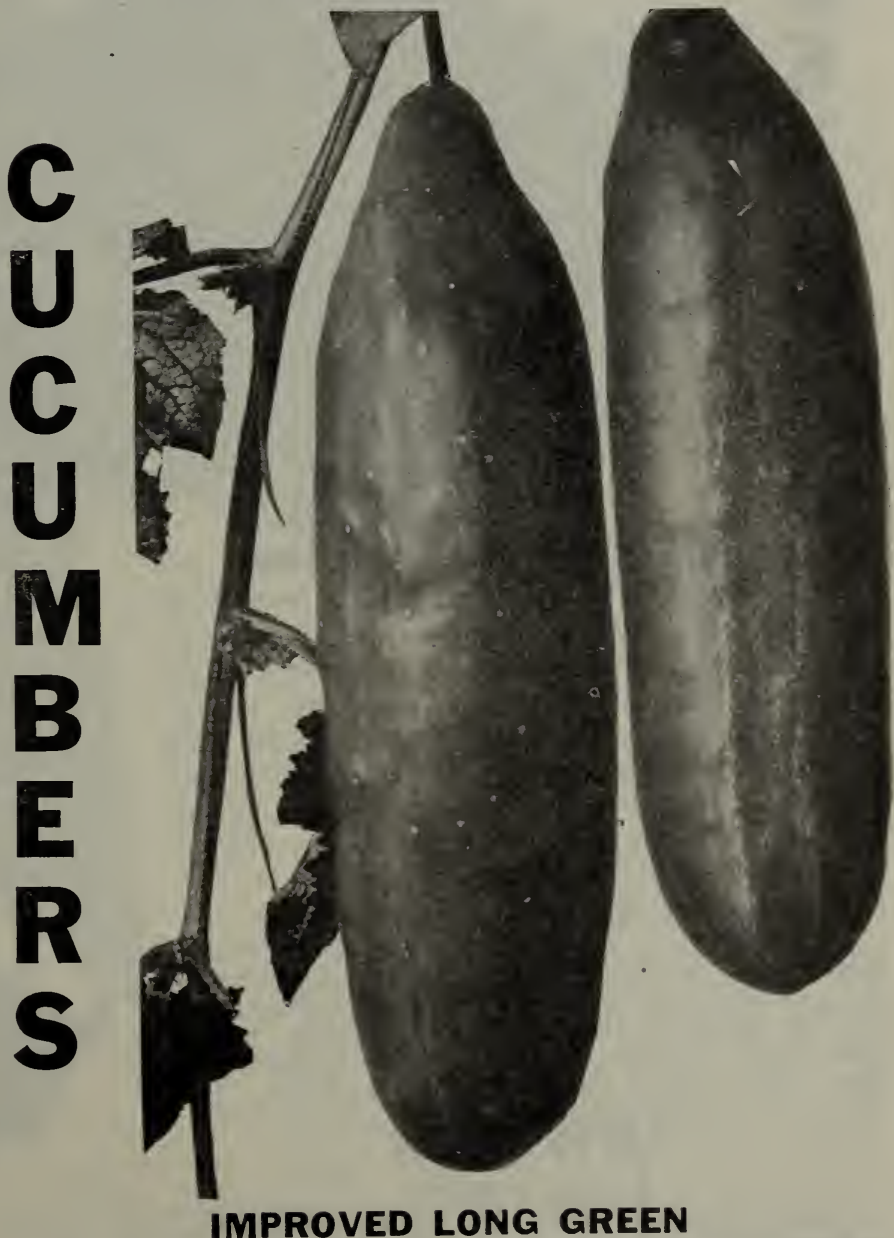

If you have had any trouble in raising cucumbers in the past, order a few pot grown plants. We find that by using them much better results are obtained. Plants $15 \mathrm{c}$ each. Pkt.. 10c; oz., 20c; $\frac{1}{4}$ lb., 35c. 


\section{We will gladly send you
samples of grass seed $\quad$ WODRUFF $\frac{5}{2}$ OYCE $\quad$ We want your business

\section{CUCUMBERS-Continued}

IMPROVED LONG GREEN

Grows 10 to 12 inches long, but makes fine pickles when young; the full sized fruits are best for sweet pickles and slicing. Dark green in color, firm and crisp; quality excellent. A prolific bearer. Pkt., 10c; oz., 20c; 1-quarter lb. 35c, 1 lb. $\$ 1.00$

\section{BOSTON PICKLING CUCUMBER}

Short, smooth and pointed; bright green; great yielder; one of the best for pickling. Pkt., 10c; oz., 20c; 1-4 lb., 35c; 1 lb., \$1.00.

\section{YELLOW GLOBE DANVERS}

An onion of the largest size and nearly globular in form. Skin is yellowish brown; flesh is white, mild and tender. It is one of the best of the large European sorts. If started very early in hotbeds, it will produce a mammoth onion the first season. Pkt., 10c; oz., 30c; 1-quarter lb., 75c 1 lb., $\$ 2.50 ; 10$ lbs. $\$ 22.50$.

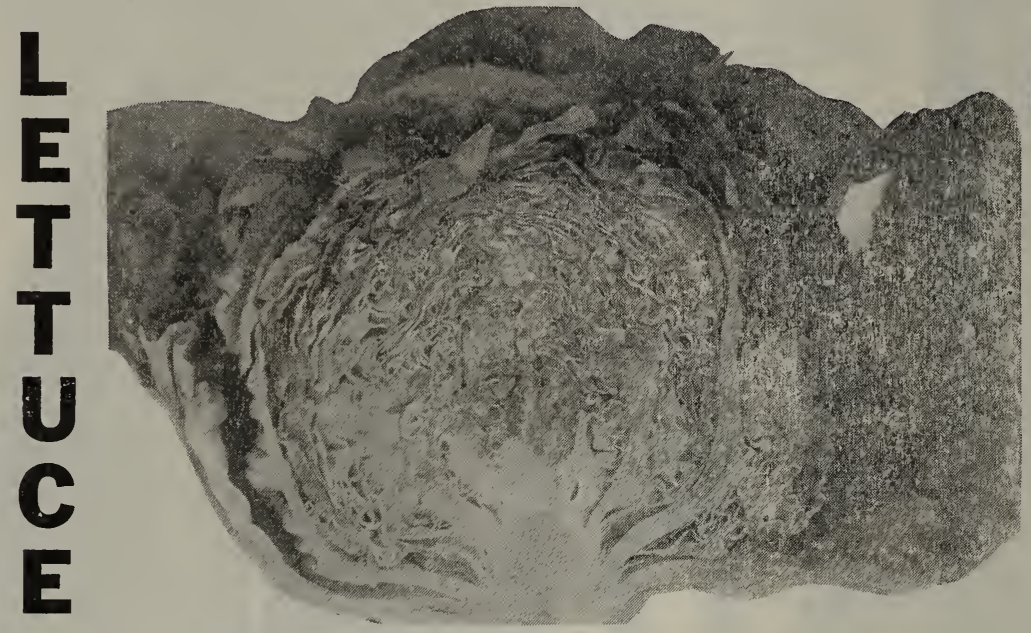

WONDERFUL OR NEW YORK

This is the finest variety of head lettuce in the market and rapidly taking the place of all others grown by the market gardeners. The heart bleaches beautifully and is crisp, tender and delicious. It roots deep and is thus able to resist hot, dry weather. It is grown extensively in all sections of the country as a standard summer variety. Pkt., 10c; oz., 75c; 1quarter lb., $\$ 2.50$.

\section{GRAND RAPIDS FORCING STRAIN}

The well-known forcing variety for the Middle West, where butter-headed or cabbage varieties do not grow well under glass. Is a loose-bunching variety forming no definite head. Is extremely curly, and its light yellowish-green color makes it very attractive. Pkt., 10c; nz., 20c; 1-quarter lb., 50c; lb., $\$ 1.50$.

\section{ONIONS}

\section{AILSA CRAIG}

A very large imported variety, rapidly gaining popularity in America. This is one of the largest of all varieties of onions which is used very extensively in private gardens for ordinary use and for exhibition purposes. It is a little flattened at the base and slightly pointed at the top. The skin when ripe is rather dark straw color, the flesh pure white, very mild in flavor and always quite tender. Pkt., 10c; oz., 50c.

\section{YELLOW ONION SETS}

If you want to have early onions in your garden, use our Yellow Onion Sets. The trouble is much less than if seed is used and the crop more certain, as the danger from insects is reduced to a minimum. When grown for family use, only, the difference in expense is a trifle compared to the advantages gained. Lb., 30c; 10 lbs., $\$ 2.50$.

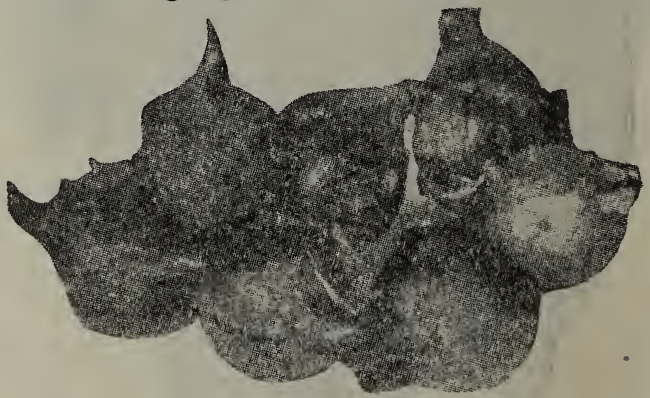

SILVER SKIN

This is the leading variety for table or bunching onion; sweet, mild flavor; matures very early. The best pickling variety. Pkt., 10c; oz., 35c; 1-quarter lb., $\$ 1.00 \cdot$ lb., $\$ 3.00$. 


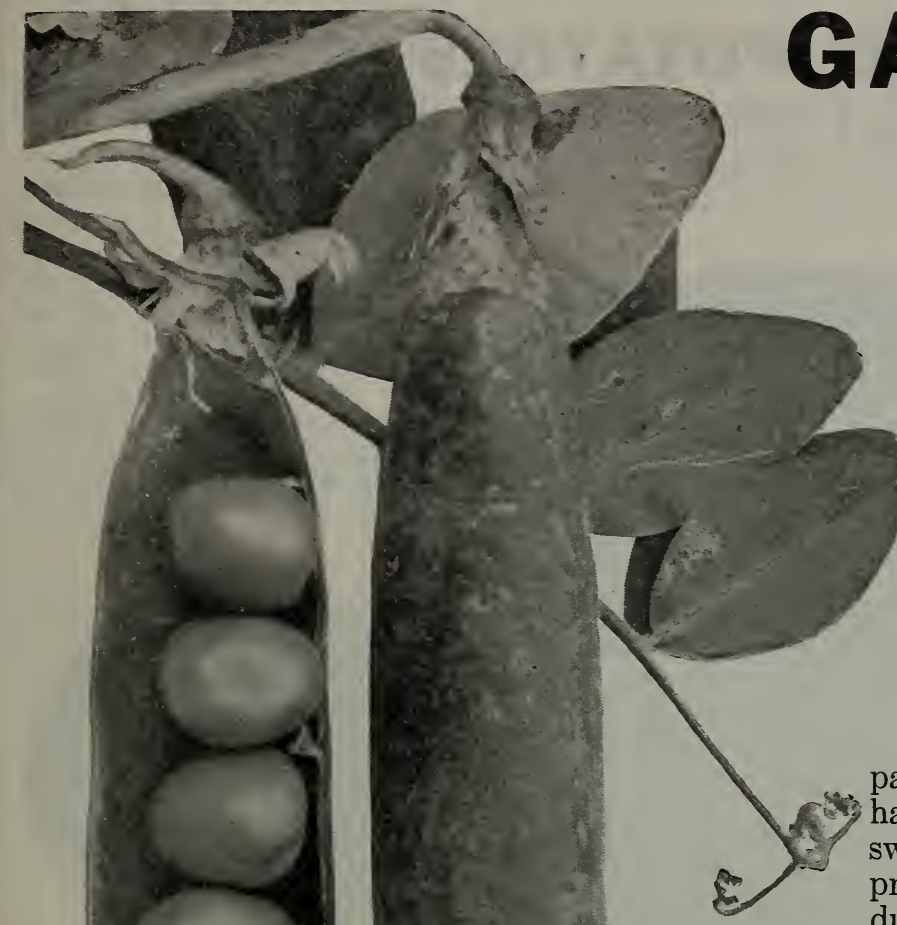

\section{LATE VARIETY ALDERMAN}

An improvement over the Telephone. The vine is a large quick grower with well filled pods. Probably the best of the tall varieties. Large wrinkled peas of fine flavor. Pkt., $15 \mathrm{c}$; lb., 35c, postpaid; 10 lbs., $\$ 2.75$.

\section{EARLY VARIETIES} AMERICAN WONDER

The first variety of dwarf, compact growth and early maturity, having a wrinkled seed and rich, sweet flavor. While a number of improved varieties have been introduced since, this still remains a leading favorite for home and market. The vines grow only 8 to 10 inches high, and pods mature in quick succession to the Extra Early. Pkt., 15c; lb., 35c; postpaid. $10 \mathrm{lbs}$, $\$ 2.75$.

\section{GRADUS OR PROSPERITY}

The earliest, largest, highly flavored pea grown. We have some extra fine local grown seed that will produce wonderful results. This, together with a later variety, should be planted in every garden.

The vine is vigorous, robust, heavy stemmed, and grows only two and onehalf to three feet high. The pods are large and are filled with six to ten very large, wrinkled, marrow peas of the most delicious flavor; as large, sweet, and tender as the finest late peas. Our seed is grown from the original strain, acclimated in the Northwest. Pkt., 15c; lb., 35c; 10 lbs., \$2.75.

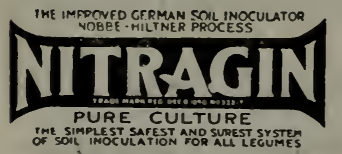

AWAROD COD MEDU ST LOUIS, ISOA is nature's own fertilizer for the legumes. Increase your yield of Peas two fold by using Nitragin. It will pay you even on a small patch. Garden size, 50c per can. Postpaid when included with an order. 


Our seeds insure you a
prolifio orop

\title{
SEED POTATOES
}

Our seed is specially selected from True to Type Stock and when grown under favorable conditions will produce abundantly proving one of the most profitable crops that can be grown in the Northwest. It is just as important to exercise care in selecting potato seed as it is in breeding stock.

\begin{abstract}
"SENSATION" is a fine potato and is a favorite with all who have grown it. Try it this season and you will agree with us that it is one of the best.
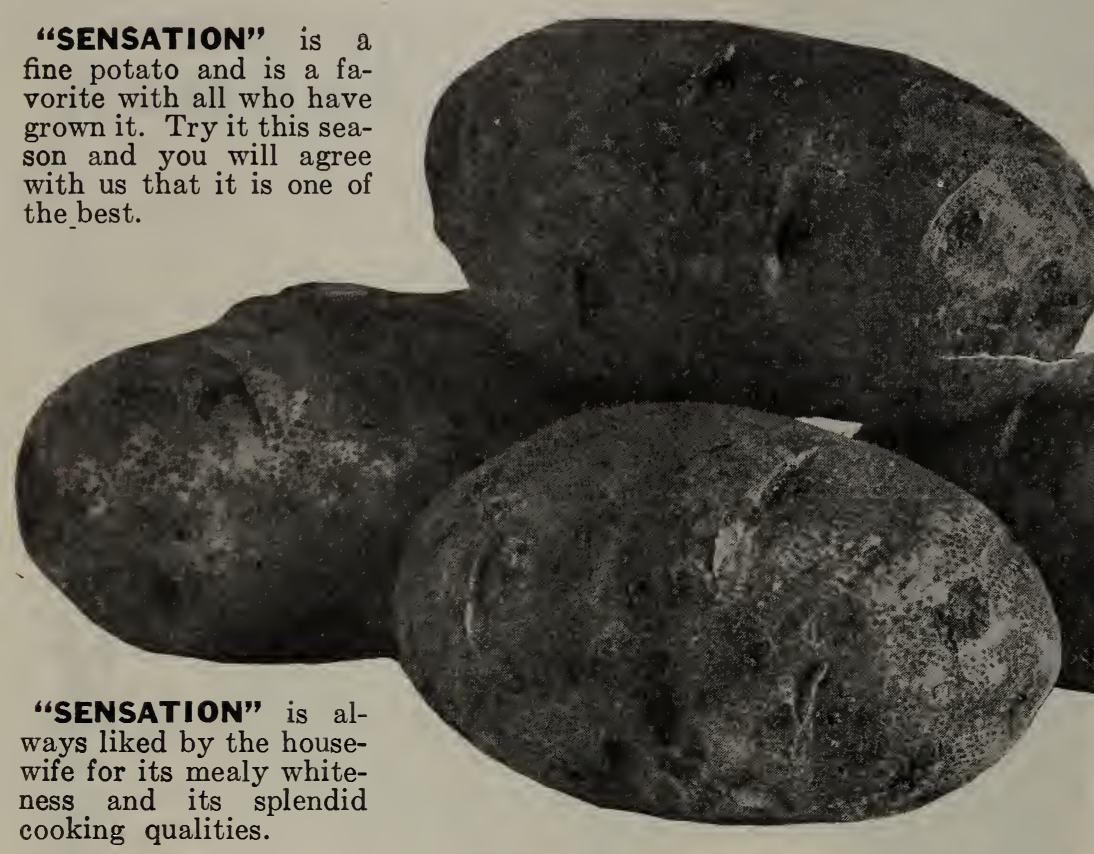
cooking qualities.

"SENSATION" is a phenomenal cropper and one of the finest looking potatoes ever grown. The looks of a potato has much to do with its marketable qualities and "SENSATION" is surely a winner.

\section{SENSATION}

Our leading variety for the last four years has been the Sensation. It is by far the best early variety we know of. It produces an extremely heavy crop of heavy large, slightly flattened tubers, smooth, white skinned and very attractive in appearance. Per lb., $10 \mathrm{c} ; 25$ bs., $\$ 2.50 ; 100$ lbs., $\$ 6.00$.

Notice.-We do not pay postage, express or freight charges on potatoes and where postage is not included will deduct the charge from the money sent.
\end{abstract}

\section{EARLY ROSE}

We have been fortunate in being able to buy up some Early Rose seed grown from stock recently imported from Maine, the best potato state in the country. Early Rose is too well known to need much description. It is one of the best of the early varieties and one of the old standbys. Good seed has been scarce of late years and we are fortunate in being able to offer you this strictly thoroughbred seed. Per lb.,10c; 25 lbs., $\$ 2.00 ; 100$ lbs., $\$ 5.50$.

Notice.-We do not pay postage, express or freight charges on potatoes and where postage is not included will deduct the charges from the money sent.

\section{GOLD COIN}

The Gold Coin is rapidly becoming a favorite in this locality. It is a medium early white potato; it is an exceedingly heavy cropper of large, smooth skinned, oval shaped tubers. 'The eyes are very shallow and distinct. It is a very healthy and vigorous variety as is attested by the vine and solidity of the tubers. Per lb., 10c; 25 lbs., $\$ 2.00 ; 100$ lbs., $\$ 5.50$.

Notice.-We do not pay postage, express or freight charges on potatoes, and where postage is not included will deduct the charges from money sent.

Formaldehyde for scab, scale, etc. 1 pt. will treat $100 \mathrm{lbs}$. of seed; 60c. Cannot be mailed.

You can produce all the potatoes you can use and sell some to your neighbor. A sack of fertilizer will produce the surplus. 


\section{PARSLEY}

\section{No Garden. Is Complete Without a Few Plants}

Densely crimpled and curled, dark green leaves; beautiful for garnishing; a very select and productive stock. Pkt., $10 \mathrm{c} ;$ oz., 20c;1-quarter lb., 50c; 1 lb., $\$ 1.50$.

\section{PUMPKINS \\ Monmouth Tours}

This strain produces the biggest Pumpkins grown, sometimes measuring 6 feet in circumference and weighing 200 to 250 pounds; outside color, deep orange yellow; flesh very thick, fine grained, tender, of bright yellow color, and of excellent quality for pies and other uses. Pkt., 10c; oz., 20c; 1-quarter lb., 50c; 1 lb., \$1.50.

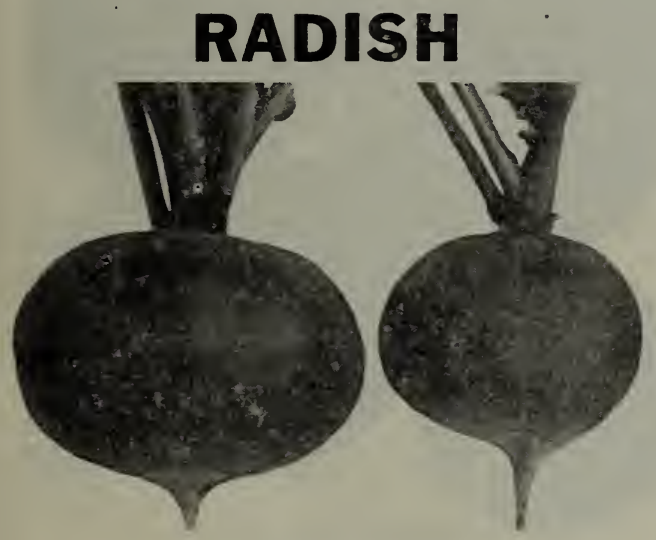

\section{Scarlet, White Tipped}

This is the most popular variety of all amongst private gardeners. It is a most satisfactory sort in every respect and surpasses as a table radish. The flesh is crisp, white and tender, and very mild. Pkt., 10c; oz., 20c; 1-quarter lb., 35c; 1 lb., $\$ 1.00$.

\section{A Japanese Radish Sakurajima}

A Japanese variety, grown to enormous size, often 12 inches long. Pure white and flesh is always mild, crisp and tender. The Japanese gardeners make a specialty of growing them. Pkt., $10 \mathrm{c}$; oz., $30 \mathrm{c} ; 1$ quarter lb., $75 \mathrm{c}$.

\footnotetext{
All our specials are a little better than the standard varieties.
}

\section{RHUBARB SEED}

Should be sown during April or May in drills one foot apart, covering the seed about onehalf inch. Later thin out the seedlings to four inches apart and in the fall transplant to permanent beds of well enriched soil, setting plants not less than three feet apart. They will be in condition for use the following year. Per pkt., 10c; oz., 35c.

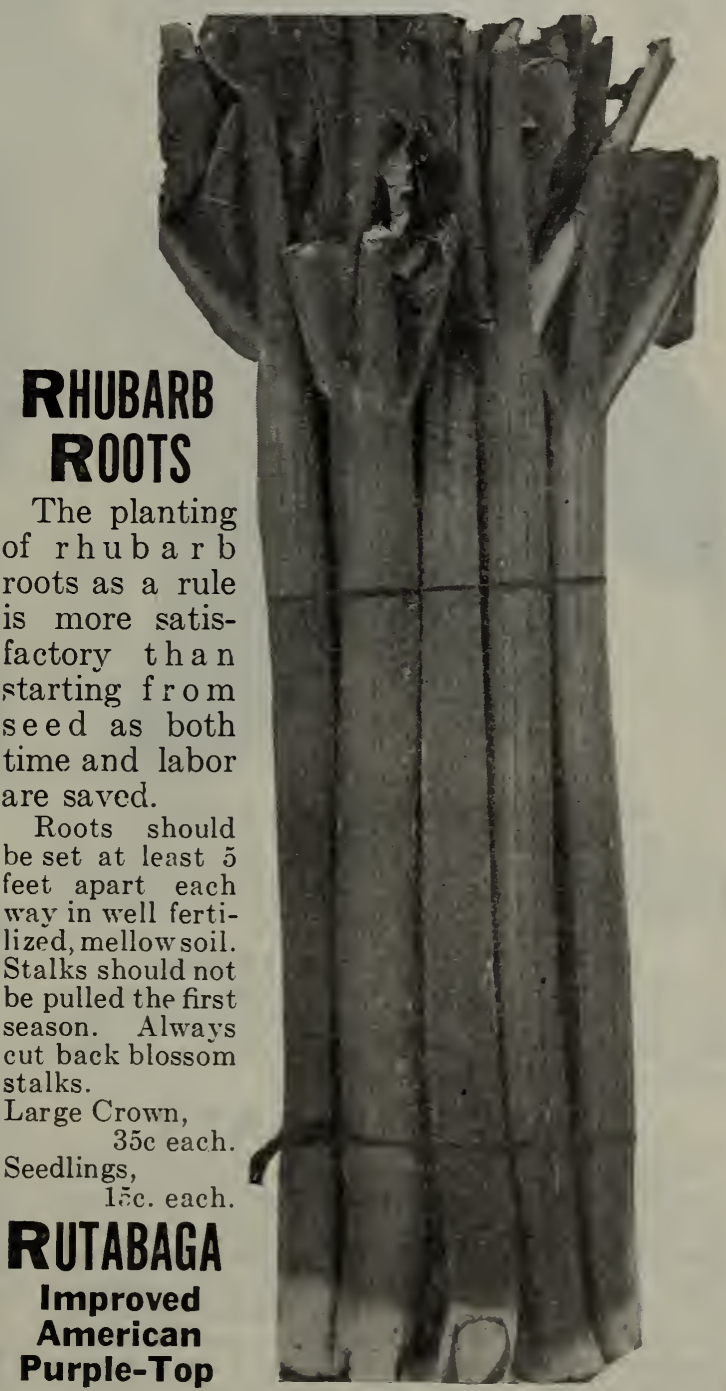

This strain is of American origin, bred to a smaller top and short neck. The bulbs are of great size, yellow-fleshed and purple crown; one of the most desirable varieties now cultivated. Pkt., 10c; oz., 20c; 1-quarter lb., 35c; 1 lb., $\$ 1.00$. 


To plant too early
causes failures

\section{SQUASH-HUBBARD}

This new fall and winter squash resembles the old Hubbard; average weight is between five and ten pounds. Seed cavity small; flesh exceedingly thick, compact, fine grained; color, golden orange. The flesh is meaty, granulated, tender and almost of mealy dryness, cooking sweet and rich, whether steamed, baked, boiled or made into pies. Pkt., 10c; oz., 20c; 1-quarter lb., 50c; lb. $\$ 1.50$.

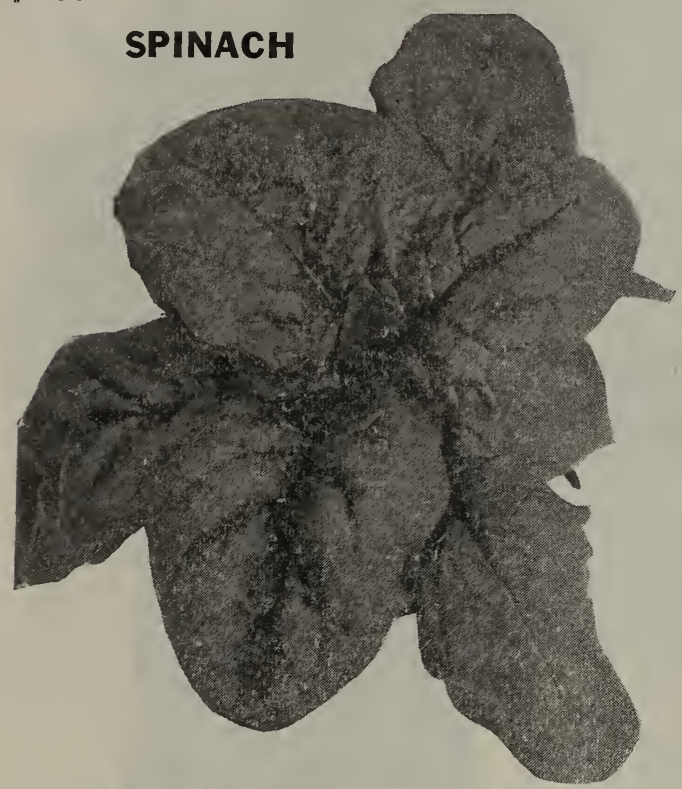

EARLY GIANT THICK-LEAVED

A quick growing sort and one of the best for wintering over. It is of large size, rich green color and excellent quality. Pkt., 10c; oz., 20c; 1-quarter lb., 30c, lb., $75 \mathrm{c}$.

\section{BLOOMSDALE SAVOY LEAVED}

The popular fall Spinach so largely grown for market. Grows upright, the leaves being crumpled, dark green and very thick. Pkt., 10c; oz., 20c; 1-quarter lb., 30c 1 lb., $75 \mathrm{c}$.

\section{TOMATO PLANTS}

For early varieties set plants 4 feet apart each way in warm, mellow soil of fair fertility as soon as danger from belated frost is past. For main crop plant in fairly warm soil, 5 feet apart each way. A very ornamental show can be made in the home garden by training tomato plants to stakes, poles or trellis. Applications of superphosphate, or of some good complete (vegetable) fertilizer of ten have a very happy effect on Tomatoes in hastening maturity and increasing the yield.

Leading varieties. Transplanted into flats. Doz., 35c, 100, $\$ 2.2 .5$ postpaid; $1,000, \$ 17.50$ by freight or express. Pot grown, doz., $\$ 2.00$, postpaid.

\section{TOMATO SEED}

\section{Early Sunshine Tomato}

The very earliest and best variety for outdoor culture. The plant is strong in constitution and is the heaviest cropper of all the new sorts. It produces bunches of ten to fourteen tomatoes freely. The fruits are of medium size, perfectly round, smooth, and of the finest quality. Trade pkt., 25c.

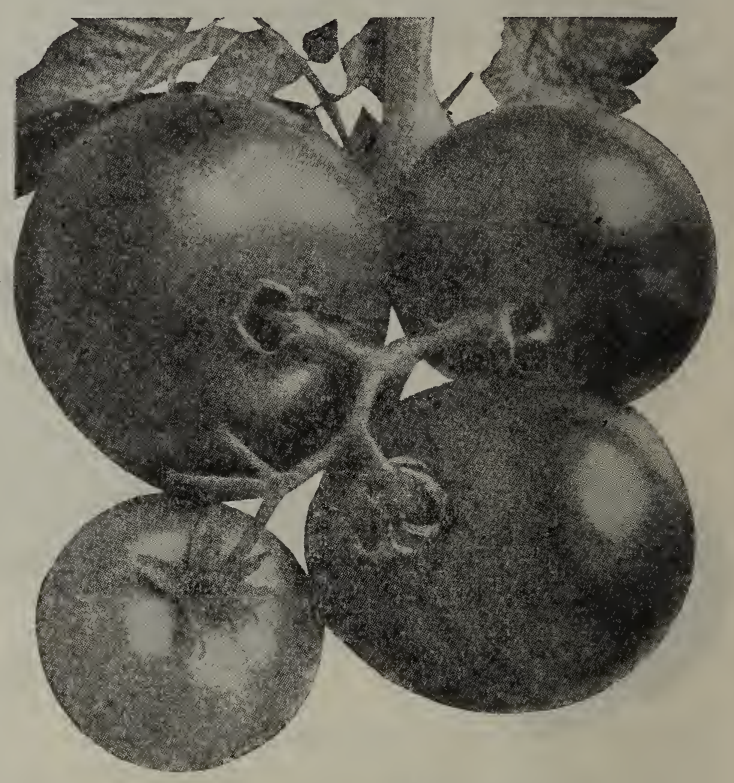

\section{SPARKS' EARLIANA}

The tomatoes are bright red and grow close together in clusters; all of medium size, averaging two and one-half inches in diameter. They are smooth and solid, quite thick through and free from rough ribs or cracks. The flesh is a deep red, with solid center and small cells; slightly acid flavor. Best for this vicinity. Pkt., 10c; oz., 20c.

\section{TURNIPS (Petroski)}

The earliest and best golden yellow turnip. Resembles the Golden Ball, but is sweeter and comes earlier. Pkt., 10c; oz., $20 \mathrm{c} ; 1$-quarter lb., 50c; 1 lb., $\$ 1.50$. 


\section{REMEMBER---OUR Seeds are TESTED SEEDS}

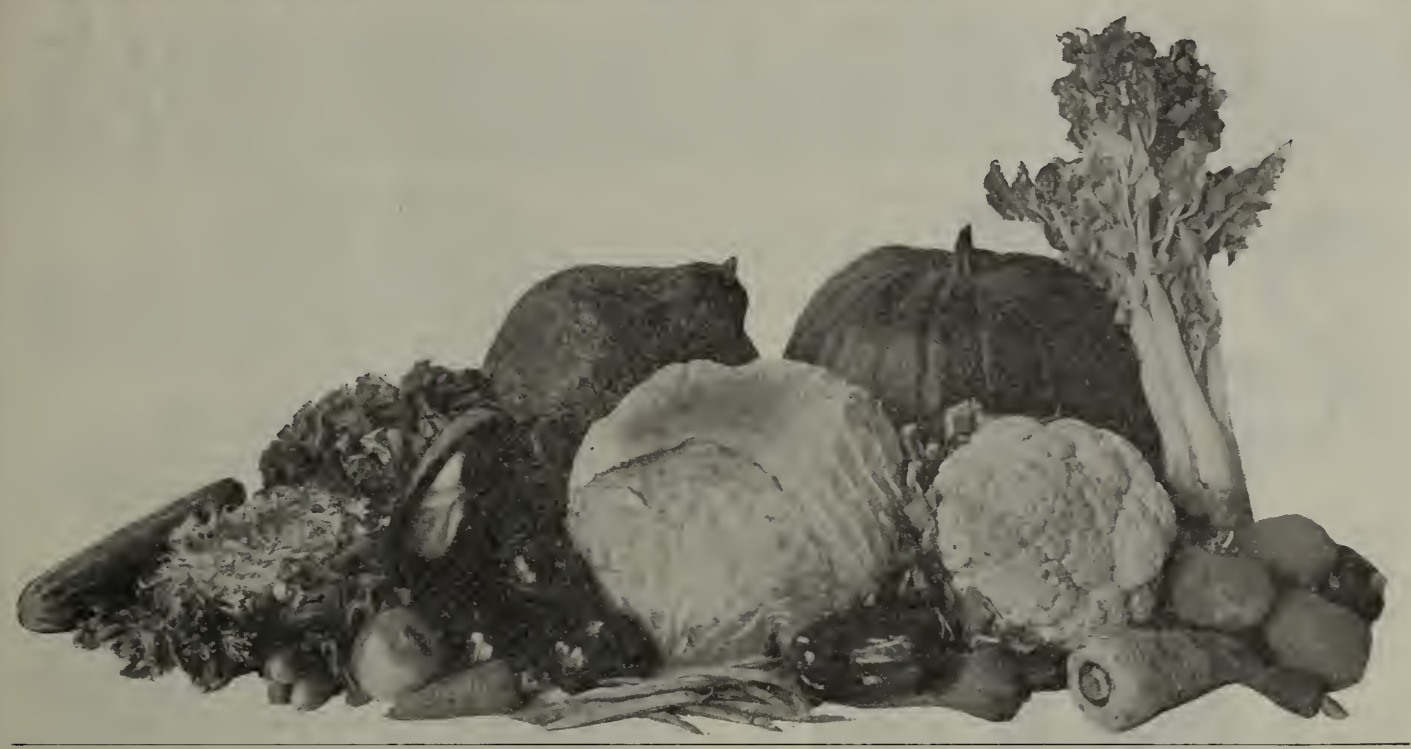

POT, SWEET AND MEDICINAL SEEDS

NAME OF SEED

ANISE. Seeds aromatic.

BORAGE. Leaves used as salad.

BASII. Sweet for flavoring

CATAWAY For flavoring

CFrRVIr. Double Curled

CORIANDER. For flavoring.

CATIIP. Cat mint.

DII. For flavoring

IAVINDER. Fragrance...

MARJORAM. Sweet._...

MINT. Peppermint, $100^{\circ}$ seeds_._.

\section{ARTICHOKE}

Sow the seed early in May and transplant into rows 3 feet apart in deep, rich soil. Protect during winter.

\section{FRENCH GREEN GLOBE.}

Pkg., 5c; oz., 3 כ̃c.

JERUSALEM, OR TUBEROUS ROOTED.

Grown especially for hog feed and often yields 20 tons to the acre. Per 1b., $10 \mathrm{c}$ postpaid; 100 lbs., $\$ 5.00$ by freight.

\section{ASPARAGUS}

Sow one ounce for 60 feet of drill. When two years old transplant into permanent beds which hould be well and deeply manured to the depth of two feet. Set the plants from 3 to 4 feet apart and 2 feet in the row, spreading out the roots and covering from 6 to 8 inches. On the approach of winter cover with manure. Fork the bed early in the spring and apply a dressing of salt. Cut for use the second year after planting in permanent bed.

COLUMBIA MAMMOTH WHITE.

Producing large white shonts in abundance of extra fine quality. Pkt., $5 \mathrm{c}$; oz., $25 \mathrm{c}$.

\section{CONOVER'S COLOSSAL.}

A standard white variety that is used exclusively for canning. Pkt., 5c; oz., $25 \mathrm{c}$.

PALMETTO.

A very large early and prolific green variety. The one mostly planted. Pkt., 5c; oz., $25 \mathrm{c}$.

\section{ASPARAGUS ROOTS}

Large vigorous, two-year-old roots of Palmetto and Colossal varieties always on hand. Best results are obtained by planting in February. For prices see page 32 .

\section{GOOD SEEDS are essential, but to obtain the best} results your soil must be good. Use our fertilizers and note the difference in results. 


\section{BEANS}

\section{CULTURE.}

Beans require a light friable soil, with plenty $n t^{+}$moisture, and they are sensitive to frost. They should not be sown earlier than April. In the garden the soil should be made mellow and rich, and all pole varieties should be provided with poles or a trellis on which to climb. For a garden crop plant string beans in a succession every four weeks throughout the season. Sow in rows 18 to 24 inches apart and cover them from one to two inches deep but not more. Keep the pods picked and the vines well watered and the beans will continue bearing much longer than if vines aro allowed to become dry.

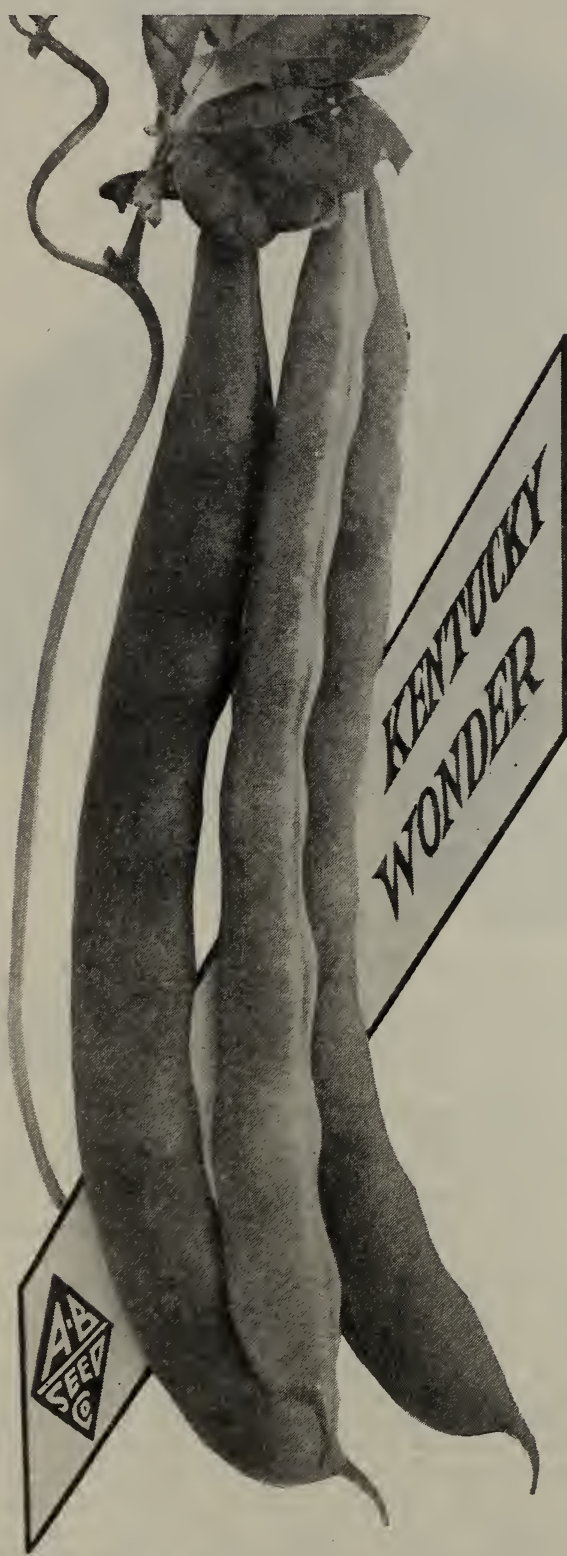

KENTUCKY WONDER.

The Most Popular of All Pole Beans.

\section{POLE BEANS} KENTUCKY WONDER.

The vine is vigorous, climbing well and very productive bearing, its pods in large clusters of ten reaching nine to ten inches in length. They are nearly round and very crisp when young. Pkt. $15 \mathrm{c}$; lb., $35 \mathrm{c}$, postpaid. $30 \mathrm{c}$ lb.; 10 lbs., $\$ 2.50$, by rreight or express.

\section{KENTUCKY WONDER WAX.}

This is the same as the Kentucky Wonder except the pods, which are wax instead of green. Price, pkt., $15 \mathrm{c}$; 1b., 35c, postpaid. 1 lb., $30 \mathrm{c} ; 10$ lbs., $\$ 2.50$, by express or freight.

\section{TALL HORTICULTURE OR CRANBERRY.}

An old favorite. Pods short, pale green, becoming splashed with brownish red. Valuable either green or dry shelled. Pkt., $15 \mathrm{c}$; $1 \mathrm{~b} ., 35 \mathrm{c}$ postpaid. $30 \mathrm{c}$ lb.; 10 lbs., $\$ 2.50$, by freight or express.

\section{DUTCH CASE KNIFE.}

A climbing variety with long, flat, irregular pods, which become creamy white as they mature. Seeds broad, flat and clear white. Pkt.. $15 \mathrm{c}$; lb., $35 \mathrm{c}$, postpaid. $30 \mathrm{c}$ lb.; 10 lbs., $\$ 2.50$, by freight or express.

\section{LAZY WIFE.}

This sort is very popular, as its name indicates. A handful of choice stringless beans at a grab. The beans ar 3 white and make a fine bean for winter use. Pkt., 15c; 1b., 35c, postpaid. 30c lb.; $10 \mathrm{lbs}$., $\$ 2.50$, by freight or express.

\section{WHITE CREASBACK.}

An early green podded variety. Pods five to six inches in length, deeply creased or saddle backed and borne in clusters. Are very fleshy and stringless. Pkt., $15 \mathrm{c}$; lb., $35 \mathrm{c}$, postpaid. $30 \mathrm{c}$ lb.; 10 lbs., $\$ 2.50$, by freight or express.

LARGE WHITE LIMA OR BUTTER.

A splendid pole variety, quite early, rich and fine flavored. Pkt., $15 \mathrm{c}$; lb., 30c.

CLIMBING FLOWERING BEAN, SCARLET RUNNER.

Erpecially used as a flowering bean. Pkt., 15c; 1 lb., $30 \mathrm{c}$

\section{FIELD OR DRY BEANS}

\section{LADY WASHINGTON FIELD BEAN.}

This white field bean is an improvement over the old Navy Bean; is earlier, larger, and more productive. Especially adapted to the West. Pkt., $15 \mathrm{c}$; lb., $35 \mathrm{c}$, postpaid. $30 \mathrm{c}$ lb.; $10 \mathrm{lbs}$., $\$ 2.50$, express or freight.

WHITE NAVY BEAN.

The well-known small white field bean. It is of little use as a snip bean, and is grown for the dry shelled beans only. Pkt., $15 \mathrm{c}$; 1b. $35 \mathrm{c}$, postpaid. $25 \mathrm{c}$ lb.; 10 lbs., $\$ 2.50$, express or freight.

\section{VINELESS MARROW.}

A most prolific and valuable bean for fleld culture. Plants large. strong and vigorous and without runners. The dry beans are medium large, oval and very white and of exceptionally fine ruality. Price. pkt., 15c; 1b., $35 \mathrm{c}$, postpaid. ih., $30 \mathrm{c}$ : 10 ibs., $\$ 2.5 n$, bv express or freight.

\section{We Carry a Complete Line of Garden Tools. A Planet Junior Cultivator




\section{BEANS-Dwarf or Bush}

\section{WAX PODDED}

WARDWELL'S KIDNEY WAX.

Most popular of all varieties for either market or home use. Matures in five to six weeks. A strong, vigorous grower and bearing heavy crops. Pkt., 15c; lb., $35 \mathrm{c}$, postpaid. $30 \mathrm{c}$ lb.; $10 \mathrm{lbs} .,-\$ 2.50$. by freight or express.

\section{DAVIS' WHITE KIDNEY WAX.}

This rariety is the most hardy and productive of the wax beans. The one the market gardeners plant the most of and the finest flavored bean we know. Pkt., $15 \mathrm{c}$; lb., 35c, postpaid. 30c lb.; 10 lbs., $\$ 2.50$, by freight or express.

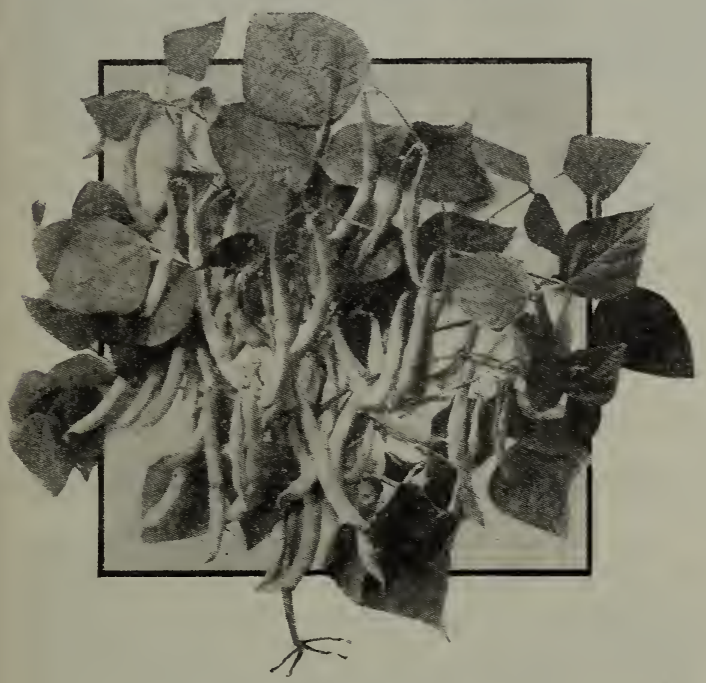

SUPERIOR GOLDEN WAX.

An old, well-known variety that does especially well in this section of the country. Pods long. semi-round, golden yellow in color. Pks., $15 \mathrm{c}$; lb., $35 \mathrm{c}$, postpaid. $30 \mathrm{c}$ lb.; 10 lbs., $\$ 2.50$, by freight or express.

\section{PROLIFIC WAX, BLACK SEEDED.}

A favorite main crop wax variety. They are solid and tender. A great producer and one of the varieties we recommend for the home gardens. Pkt., 15c; lb., 35c, postpaid. 30c lb.; 10 lbs., $\$ 2.50$, by freight or express.

\section{SCARLET RUST PROOF WAX.}

This handsome variety of intermediate season seems to do especially well in the south and is a favorite with many truckers. The plants are large, strong growing, erect and produce very long, flat, rather coarse, deep rellow wax-like pods seven to eight inches in length. Seed very large, flat, bright red changing to plum-violet. Pkt., 15c: lb., 35c, postpaid. $30 \mathrm{c}$ lb.; 10 lbs., $\$ 2.50$, by express or freight.

\section{GREEN PODDED}

\section{BURPEE STRINGLESS}

This variety produces an abundance of large. green pods, which are very tender and of excellent flavor. One of the earlier sort Pods are long and slender. Pkt., $15 \mathrm{c}$; 1b., $35 \mathrm{c}$, postpaid. $30 \mathrm{c}$ ?b.; 10 lbs., \$2.5c, by express or freight.

EARLY LONG YELLOW-SIX WEEKS.

A long podded green variety. Plants strong and vigorous. Seeds long kidney shaped, light vellow. Pkt., 15c: lb., $35 \mathrm{c}$, postpaid. $30 \mathrm{c}$ jb.; 10 ibs., $\$ 2.50$, by express or freight.

\section{REFUGEE, OR 1000 TO 1}

A variety much later than other green pods. Plants large, strong, very hardy and a heavy yielder. Seeds yellowish heavily splashed with bluish-black. Plit., $15 \mathrm{c} ; 1$ lb., $3 \check{\mathrm{c}}$, postpaid. $30 \mathrm{c}$ lb.; 10 lbs., $\$ 2.50$, by express or freight.

\section{EARLY RED VALENTINE.}

A popular variety. Pods of medium size and length, practically stringless. Seed pink marked with red. Pkt., $15 \mathrm{c}$; $1 \mathrm{~b} ., 35 \mathrm{c}$, postpaid. $30 \mathrm{c}$ lb., 10 lbs., $\$ 2.50$, by express or freight.

\section{BLACK VALENTINE.}

A very hardy and green podded variety. Pods are nearly round or slightly flattened and matures medium early. A large crop can be depended on and it is on of the best shipping varieties that we have. Pkt., 15c; 1b., 35c.

\section{DWARF HORTICULTURAL.}

A very vigorous variety with large leaves; used as a shell bean, green or dried. Pods are of medium length, slightly curved, and when nearly ripe are striped and splashed with crimson on yellowish-brown; seed pale pink, splashed with bright red. Pkt., $15 \mathrm{c}$; 1b., $35 \mathrm{c}$, postpaid. By express or freight, $1 \mathrm{~b} ., 30 \mathrm{c} ; 10$ lbs., $\$ 2.50$.

\section{HOOVER'S SPECIAL.}

We have discovered a local grown bean which in our estimation is one of the best green podded beans grown. We have taken the liberty of naming it after our Food Administrator. This hardy sort can be planted earlier than others and in this way will often furnish beans fit for use before any other green podded variety. The plants are large and stout, with large coarse, dark green leaves. The pods are medium dark green, long, six to six and one-half inches, straight, coarse, flat, with long tapering points. Seeds are large, oval and slightly flattened, white, mottled with red. Makes a splendid dry bean. Pkt., 15c; lb., $35 \mathrm{c}$, postpaid. $30 \mathrm{c}$ lb.; 10 lbs., $\$ 2.50$, by express or freight.

\section{ENGLISH, OR BROAD WINDSOR.}

This is not a string bean of any sort but a very well-known, popular variety with many farmers. Familiarly known as the Horse Bean. Pkt., $15 \mathrm{c}$; lb., 30c, postpaid. 25c lb.; 10 lbs., $\$ 2.00$, by freight or express.

\section{BUSH LIMAS}

\section{BURPEE BUSH LIMA.}

The best late variety. Plants eighteen to twenty-four inches high, very prolific. Will bear until stopped by frost. Pkt., 15c; lb., 35c; postpaid, lb., $30 \mathrm{c}$; 10 lbs., $\$ 2.50$.

\section{DREER'S BUSH LIMA.}

Very prolific, single plants often produce 150 to 200 pods. The beans grow close together and often produce five beans to the pod. Tender, sweet and very juicy. Pkt., $15 \mathrm{c}$; $1 \mathrm{~b} ., 35 \mathrm{c}$; postpaid; 1 b., $30 \mathrm{c}$; 10 lbs., $\$ 2.50$.

HENDERSON'S BUSH LIMA.

The earliest variety of lima bean, being two weeks earlier than any other we have Beans are small. We recommend this very highly. Pkt., $15 \mathrm{c}$; 1b., $35 \mathrm{c}$, postpaid; 1 lb., $30 \mathrm{c}$; 10 lbs., $\$ 2.50$.

Increase your yield of beans by using

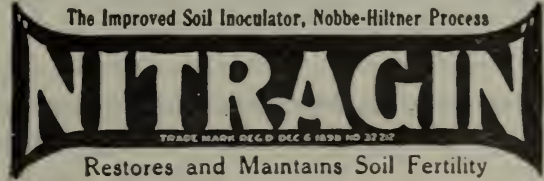


Tested Seeds are worth more Ours are tested

\section{TABLE VARIETIES}

CUITURE. The ground for beets should be rich and well spaded. In this latitude beets are sown in April and May and from August until December. Some market gardeners sow them every month in the year. Seed should be soaked twelve hours before planting. This softens the seed germs and allows the seed germ to germinate quicker. Sow in drills and thin out. Do not plant too early.

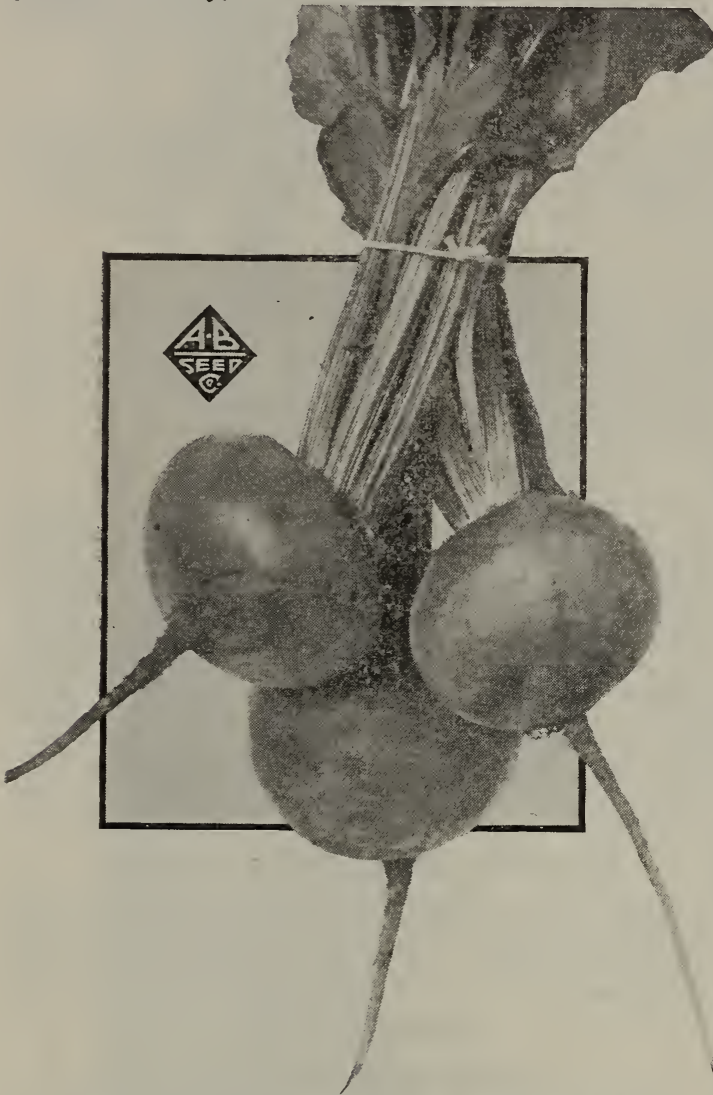

WOODRUFF'S EARLY WONDER BEET.

An improved type of blood red turnip shaped beet, very tender and sweet, regular in shape with a very small tap root; the best market gardeners' beet that we have. Pkt., 10c; oz., 20c; 4 Ib., 50c; 1 lb., $\$ 1.50$

\section{CROSBY'S EGYPTIAN.}

A round type of Early Egyptian and the best known and most popular variety. Very early and of fine quality. Bright red. Pkt., 5c; oz. $20 \mathrm{c} ; 1 / 4$ lg., $30 \mathrm{c}$; 1 lb., $\$ 1.00$.

\section{DETROIT DARK RED.}

A blood red early turnip shaped variety. Has small tops, skin and flesh dark red, very tender and sweet. A particularly desirable sort for market gardeners. Pkt., $5 \mathrm{c}$; oz., $20 \mathrm{c} ; 1 / 4 \mathrm{lb}$., $35 \mathrm{c}$; 1 lb., $\$ 1.00$
EARLY ECLIPSE.

A fine early table beet. Sweet and crisp, of romarkable fine form, smooth and free from stringy roots. Color deep red. which it retains after cooking. Pkt., $5 \mathrm{c}$; oz., $20 \mathrm{c}$; $1 / 4 \mathrm{lb} ., 35 \mathrm{c} ; 1 \mathrm{lb}$., $\$ 1.00$.

\section{EDMOND'S EARLY BLOOD TURNIP.}

A market gardener's strain, regular in shape, round and has a very small tap root; flesh a deep blood red. sweet and tender. One of the very best varities for this section of the country. Pkt., $5 \mathrm{c}$ oz., $20 \mathrm{c} 1 / 4$ lb., $35 \mathrm{c}$; 1 lb., $\$ 1.00$.

\section{EXTRA EARLY EGYPTIAN.}

An old standard sort, both for market gardeners and family use. Produces fine. smooth, deep red ronts and about ten days earlier than the Blood Turnip. Plkt., 5c; oz.,20c; $1 / 4$ lb., $35 \mathrm{c} ; 1$ lb., $\$ 1.00$.

\section{IMPROVED EARLY BLOOD TURNIP.}

Deep red, smooth, uniform size and of excellent quality. One of the best for main crops, as it keeps in condition longer than the other kinds. Pkt., 5c; oz., 20c; 1/4 lb., 35c; 1 lb., $\$ 1.00$

\section{STOCK BEETS}

\section{SLUDSTRUP MANGEL WURZEL}

\section{THE BEST IMANGEL IN THE WORLD}

The highest point of Mangel Culture has been reached in the production of THF SIUDSTRUP which has repeatedly been awarded a first-class certificate, which makes it, without a doubt, the best Mangel in the world. It is long, smooth, reddish-yellow in color, grows well above the ground, making it easy to pull, and the crop it vields is phenomenal. Our seed is from the or iginal Danish stock. Oz., 15c; 1b., 75c; 10 lbs., $\$ 5.00$.

\section{GOLDEN TANKARD MANGEL.}

Very large yellow fleshed variety. Giant ova shaped small yellow stemmed top. This is undoubtedly one of the most profitable varieties to grow for stock. as it is an enormous cropper. Try some if this variety. Oz., 15c; lb., 75c; 10 lbs., $\$ 5.00$

\section{GATE POST MANGEL.}

A yellow skinned variety with white flesh mixed with yellow. Large and oval shaped. Oz., $15 \mathrm{c}$; lb., $75 \mathrm{c} ; 10$ lbs., $\$ 5.00$.

\section{MAMMOTH LONG RED MANGEL.}

A particularly fine sort of Mangel. The roots attain enormous size, are smooth and regular in shape. Fine stock food. Oz., $15 \mathrm{c} ; 1 \mathrm{~b} ., 75 \mathrm{c} ; 10 \mathrm{lbs}$., $\$ 5.00$.

\section{GIANT HALF SUGAR}

This new Sugar Beet gives nearly as large a yield of easily grown and harvested roots as a crop of Mangels, besides being much more succulent than the ordinary Sugar Beet. It grows well above the ground and is easily pulled. Oz., $15 \mathrm{c} ; 1 \mathrm{~b} ., 75 \mathrm{c} ; 10$ lbs., $\$ 5.00$.

\section{Use our garden fertilizer on your beet patch. You will be repaid by the extra} production and get better flavor. You can can beets. 


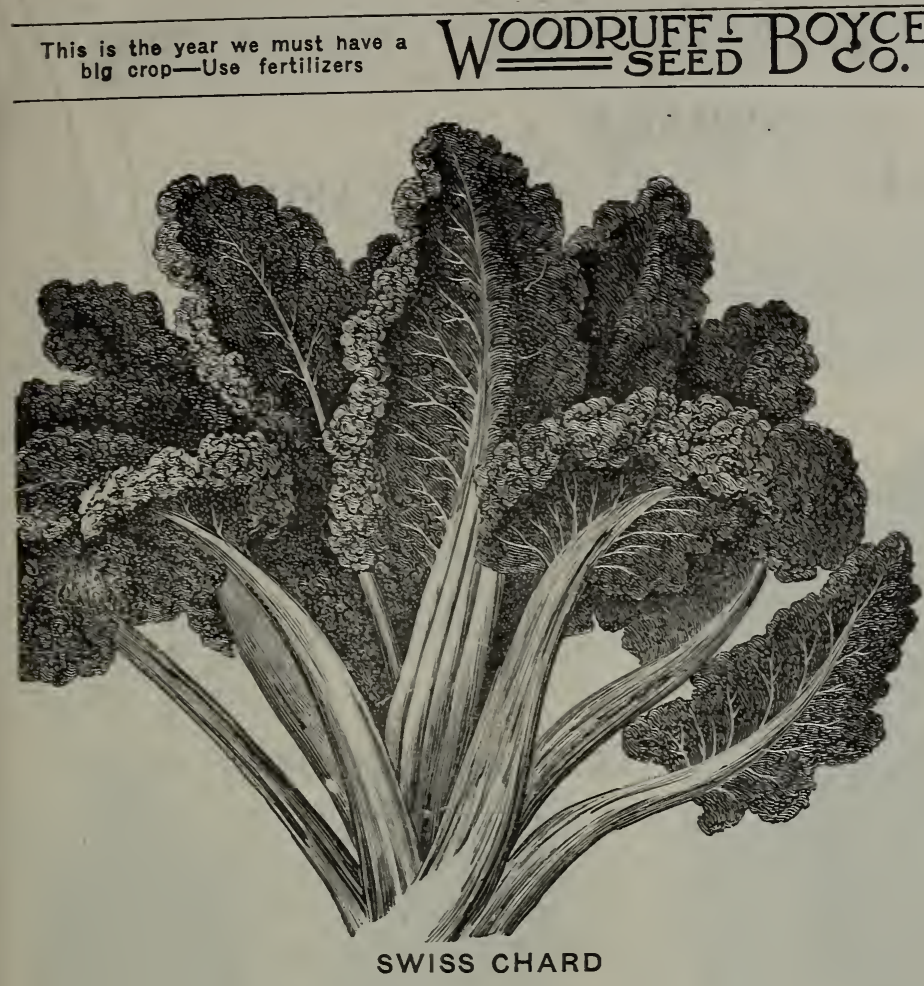

\section{CAULIFLOWER}

\section{EARLY SNOWBALL.}

Unquestionably the earliest maturing strain of the true short leaved Snowball type of cauliflower. Early Snowball is, moreover, a most desirable sort for the home garden. The plants are compact, with few, short, outside leaves and are well suited for close planting. The heads are of medium to large size, solid, compact, round, very white and curd-like. Pkt., 25c; $1 / 4$ oz., 75c; oz., $\$ 2.00$.

\section{VEITCH'S AUTUMN GIANT.}

A distinct and valuable late variety with long stems and dark green leaves. The heads are very large, white, firm and compact and being well protected by foliage, remain a long time fit for use. The plants should be started and transplanted early in the season to insure their full decelopment. Pkt., 10c; oz., 50c; $1 / 4$ lb., $\$ 1.50$.

\section{CAULIFLOWER PLANTS.}

We can supply sturdy, well-grown plants, in season, from the choicest strains at very reasonable prices.

For prices on quantities large or small write us.

\section{EXTRA EARLY DWARF ERFURT.}

A remarkably sure heading early cauliflower It is of dwarf habit with short outside leaves and is similar in most respects to Early Snowball, and nearly as early. The heads when ready for market are of medium to large size. The curd is white, exceptionally deep and of finest quality. It will give excellent results either in the home garden or for market use and is superior to most seed sold at higher prices. Pkt., $25 \mathrm{c} ; 1 / 4 \mathrm{Oz}$., $\$ 2.00$. oz., $\$ 3.00$.
Send us your order

We'll endeavor to please you

\begin{abstract}
SWISS CHARD
All the Year Round Spinach.

It is a variety of Beet, producing no bulb, only the tops, which boiled form delicious greens, better in taste than ordinary beet Greens or even Spinach. A quick grower.
\end{abstract}

SILVER RIBBED

Leaves yellowish white, curly, ribs silvery white. Pkt., $5 \mathrm{c}$; Oz., $20 \mathrm{c} ; 1 / 4$ lb., $35 \mathrm{c}$.

\section{BRUSSELS SPROUTS}

Improved Tall Hercules.

Semi-tall, new variety, closely set with solid sprouts of fine quality. Hardy sort, stands the winter admirably. Pkt., 5c; oz., $20 \mathrm{c}$; $1 / 1$ lb., $50 \mathrm{c}$.

\section{BROCCOLI}

\section{ST. VALENTINE.}

This is considered the best variety for this section; plants are hardy, vigorous and easily grown Heads are white, compact, hard and of extra fine quality and can be used in place of cauliflower. Pkt., 10c; oz., $50 \mathrm{c}$; $1 / 4 \mathrm{lb}$., $\$ 1.50$.

\section{Use our Superior Brand of Vegetable Fertilizer, it's the making of a garden An investment and not an expense}




\section{CABBAGE}

\section{CABBAGE CULTURE}

For very early use sow in January or February in hotbeds; prick out when plants are strong enough into other hotbeds; or sow in coldframes In March, transplant to the open ground when danger from killing frosts is passed, in rows two leet apart and eighteen inches in row. Cabbage succeeds best in a fresh, rich soil, well matured, and deeply dug or plowed.

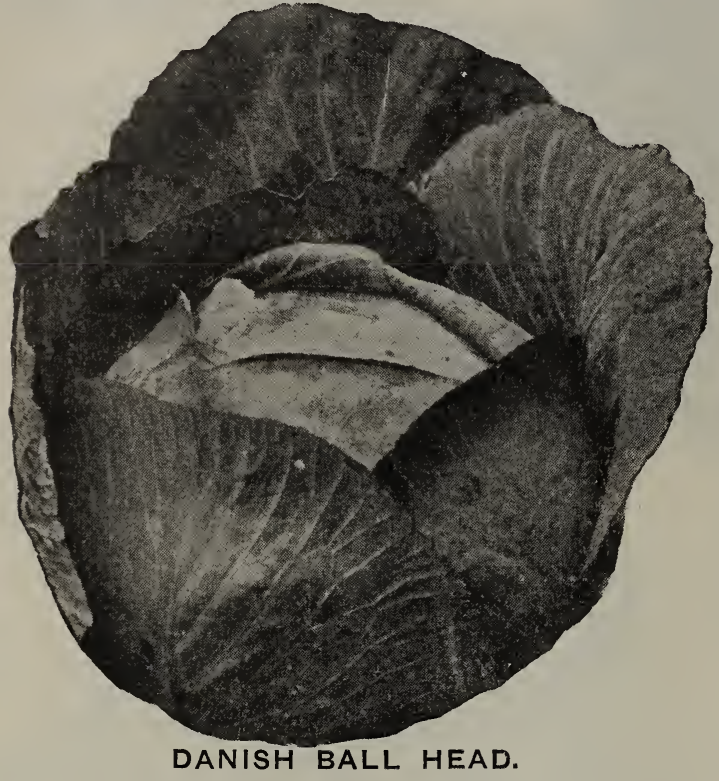

\section{EARIY VARIETIES}

\section{EARLY JERSEY WAKEFIELD}

A leading early variety, and one of the best for private or market gardener's use; conical shaped and good quality. Pkt., 5c; oz., 30c;; 1/4 lb., $\$ 1.00$; 1 lb.. $\$ 2.50$

\section{CHARLESTON OR LARGE WAKE- FIELD \\ (85 days.)}

A popular variety with market gardeners in the south. It is about a week later than Early Jersey Wakefield, but larger. Pkt., 5c; oz., 30c; $1 / 4$ lb., $\$ 1.00$; lb., $\$ 2.50$

\section{WINNINGSTADT} (85 days.)

Remarkably hard and solid, and keeps well both in summer and winter. May be sown early for late summer or later for winter use. Pkt., $5 \mathrm{c}$; oz., $30 \mathrm{c}$; $1 / 4$ lb., $\$ 1.00$; lb., $\$ 2.50$.

\section{HENDERSON'S EARLY SUMIMER}

A splendid second early cabbage, large, round, flat heads and one that is very widely known. Pkt., 5c; oz., 30c; 1/4 lb., $\$ 1.00 ; 1 b ., \$ 2.50$.

\section{COPENHAGEN IMARKET}

The finest early cabbage grown. See Specials.

\section{FALL VARIETIES}

\section{SUREHEAD}

One of the most reliable main crop or late cabbages for northern latitudes, being very hardy and exceptionally sure heading. The plants are rather upright, with many outer leaves which are waved, thin edged, crimped and distinctly frilled. stem rather snort. The heads are large and broad, thick, somewhat flattened, very solid and of excellent quality. Pkt., $5 \mathrm{c} ;$ oz., $30 \mathrm{c} ; 1 / 4 \mathrm{lb} ., \$ 1.00$; lb., $\$ 2.50$

\section{IIIPROVED AIMERICAN SAVOY}

The best of the main crop and late Savoys for home use or market. The plants are vigorous, of medium size, with rather short stem, and are very sure heading. The heads are large, nearly round, faidly solid, sweet and tender. Pkt., $5 \mathrm{c}$; oz., $30 \mathrm{c} ; 1 / 4$ lb., $\$ 1.00 ; 1 \mathrm{~b} ., \$ 2.50$.

\section{PREMIUIM LATE FLAT DUTCH}

This strain is the result of much care on our part to develop and maintain the good qualities which have made this sort so popular. The plants are very hardy, comparatively slow growing but very sure heading; stem rather short. The plants are exceptionally vigoreus. The heads are uniformly large, often very large; flat but deep, distinctly flattened on the top, solid and of excellent quality. It is an excellent keeper. Pkt., 5c; oz., $30 \mathrm{c} ; 1 / 4$ lb., $\$ 1.00 ; 1 \mathrm{~b} ., \$ 2.50$.

\section{DANISH BALL HEAD}

Very hardy, sure heading, very solid, of good quality and one of the very best keepers. The plants are vigorous and compact, with stem of medium length. They are exceedingly hardy in resisting cold and stand dry weather well. The heads are medium sized, round, exceptionally solid and stand shipment better than any other late sort. Our strain of Hollander is shorter stemmed and produces heads generally larger than other stocks. We offer seed of our own growing which, iudging from our trials, will produce more uniformly typical heads than can be grown from stock obtainable elsewhere. Our own strain. Pkt., $10 \mathrm{c}$; oz., $50 \mathrm{c}$; $1 / 4$ lb., $\$ 1.50 ; 1 \mathrm{~b} ., \$ 4.50$.

\section{MAIMIMOTH ROCK RED}

The largest and surest heading red cabbage, much better than stock offered as Red Drumhead. The plants are large and vigorous with medium length stem and spreading outer leaves which are dark green with red veining. The heads are late maturing, large, round, very solid and of very attractive deep red color. The variety is much used for cold slaw and pickling. Pkt., 10c; oz., $75 \mathrm{c}$.

\section{CHINESE CABBAGE}

See Specials-Page 3

\section{CABBAGE PLANTS}

Strong, hardy plants supplied in season. 3. See Page 32 
Do not trust to luck in buying WOODRUFF

\section{A R R O T S}

Culture-One ounce to 100 feet of row.

A light, loamy soil that has been well manured the previous year is preferred for growing Carrots, although good crops may also be obtained from ordinary garden soil. For early use seed may be sown in hotbeds from January until March, and in the open sround as soon as the weather becomes warm and settled, usually in April. Sow seed one-half inch deep in rows 15 inches apart, and later thin to 5 inches in the row. Keep soil between the rows well hoed and free from weeds.

\section{DANVERS HALF LONG}

An improved type of the Danvers Half-Long. The roots are smooth. bright orange and of handsome appearance. Pkt., 5c; oz., 20c; 1/4 lb., उ̈5c; 1b., \$1.vن.

\section{HALF-LONG NANTES}

(Stump-Rooted.) This ravorite first early sort has a rich Ieddish color, is equal to any in sweetness and one we recommend for the home garden. Pkt.. $5 \mathrm{c}$; oz., 20c; it lb., $35 \mathrm{c} ;$ lb.. $\$ 1.00$.
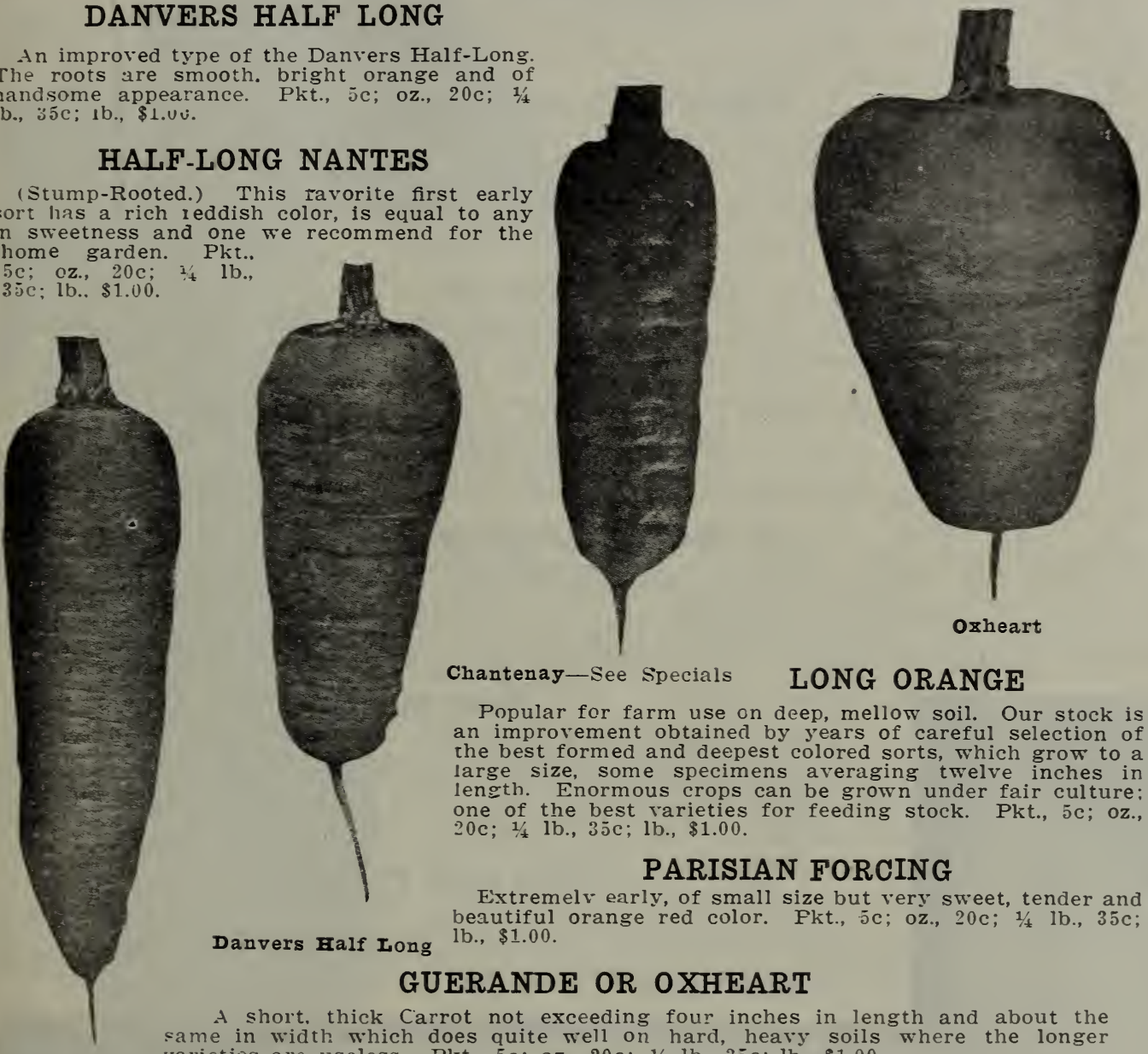

Chantenay-See Specials

\section{LONG ORANGE}

Popular for farm use on deep, mellow soil. Our stock is an improvement obtained by years of careful selection of the best formed and deepest colored sorts, which grow to a large size, some specimens averaging twelve inches in length. Enormous crops can be grown under fair culture: one of the best varieties for feeding stock. Pkt., 5c; oz., $20 \mathrm{c} ; 1 / \mathrm{t}$ lb., $35 \mathrm{c}$; lb., $\$ 1.00$.

\section{PARISIAN FORCING}

Extremelv early, of small size but very sweet, tender and Danvers Half Long lb., $\$ 1.00$.

orange red color. Fkt., 5c; oz., 20c; 1/t lb., $35 \mathrm{c}$;

\section{GUERANDE OR OXHEART}

A short. thick Carrot not exceeding four inches in length and about the same in width which does quite well on hard, heavy soils where the longer arieties are useless. Pkt., 5c; oz., 20c; 1/4 1b., 35c; 1b., $\$ 1.00$

\section{Long Orange SCARLET HORN, OR EARLY SHORT HORN}

A sood short variety for table use. The full grown type is about 3 inches long and $2 \frac{1 / 2}{2}$ inches thick at the shoulder: tapers only slightly and is very stump-rooted. Plit., 5c; oz., $20 \mathrm{c} ; 1 / 2$ lb., $35 \mathrm{c}$; Ib., $\$ 1.00$.

\section{STOCK OR FEED CARROTS}

\section{IMPROVED SHORT WHITE}

Ranks as a field Carrot, owing to its enormous productiveness and the ease with which it can be harvested. Roots half long, smooth, very heary at the shoulder, but tapering regularly to the point; rolor, light green at the crown, white below; flesh, rich, white, solid, crisp and of excellent flavor. Pkt.. 5c; oz., 20c; +1 b., 35c; 1 b., $\$ 1.00$.

\section{LARGE WHITE BELGIUIM}

Extensively grown for stock feeding; very productive. Grows so much above ground that the entire crop can be pulled by hand. Pkt., כc; oz., 20c: $1_{4}$ lb., 3ic; lb., \$1.00. 


\section{Beans are a necessity
Plant lots of them}

\section{CORN}

\section{SWEET OR TABLE VARIETIES}

Culture-Corn can be sowed in hills three feet apart each way, or in drills four to four and 8 half feet. If sowed in hills 8 to 10 pounds are required to plant an acre, and if sowed in drills, it takes from 15 to 20 pounds. The soil must be rich and the seed not covered more than one inch, and not sowed before the ground is warm. Four to six kernels are dropped into a hill. The young corn inust be hoed often, drawing the soil to the stems and breaking off side shoots.

\section{GOLDEN BANTAIM-(New)}

The new stalks are vigorous and strong, grow about 4 feet high and produce 3 to 4 fine eightrowed ears 6 to 8 inches long. On account of its firm texture it can be planted earlier than any other variety of Sweet Corn and is less apt to be bothered by worms. Plit., 15c; 1b., 35c, postpaid. 30c lb.; 10 lbs., $\$ 2.50$, by express or freight.

\section{MORSE'S GOLDEN CREAIM}

The flavor of Morse's Golden Cream is rich, nut-like and delicious, and better than other corns. It is good enough to eat raw. Morse's Golden Cream is early, prolific and a fine sort; seed yellow. Pkt., 10c; lb., 35c, postpaid. 30c lb.; $10 \mathrm{lbs} ., \$ 2.50$, by express or freight.

\section{COUNTRY GENTLEMAN OR SHOE PEG}

One of the late varieties. Has a long white cob closely filled with long small shoe peg kernels. It is remarkably fine flavored and sweet. Pkt., $10 \mathrm{c}$; 1b., $35 \mathrm{c}$, postpaid. $30 \mathrm{c} 1 \mathrm{~b} . ; 101 \mathrm{bs} ., \$ 2.50$, by express or freight.

\section{EARLY IMINNESOTA}

This deservedly.popular variety is one of the best second early sorts for the market and the home garden. The stalks are about six feet high bearing one or two ears well covered with husks. The ears are about eight inches long, eight rowed; kernels very broad, white, sweet and tencer, not shrinking much in drying. By careful selection we have developed a stock of this standard variety which is remarkably uniform and th which all the good qualities that have made this sort so desirable are intensified. Plkt., $10 \mathrm{c}$; lb., $35 \mathrm{c}$, postpaid. $30 \mathrm{c}$ lb.; 10 lbs., $\$ 2.50$, by express or freight.

\section{WHITE COB CORY}

For a strictly early for first market and home use, you can't be far wrong with White Cob Cory. We offer northern grown extra early matured seed. Pkt., 10c; lb., 35c, postpaid. 30c lb.; 10 lbs., $\$ 2.50$, by express or freight.

\section{STOWELL'S EVERGREEN}

The standard main crop variety, much used for the home garden, market and canning. It is hardy and productive, very tender and sugary, remaining a long time in condition suitable for boiling. Our stock has been carefully grown and selected to avoid the tendency to a shorter grain and deterioration in the evergreen character of this best known of all late sorts. The ears are about seven to eight inches long, fourteen to twenty rowed, with very white grain. The stalks are about seven and one-half feet high. Pkt., 10c; 1b., 35c, postpaid. 30c lb.; $10 \mathrm{lbs} ., \$ 2.50$, by express or freight.

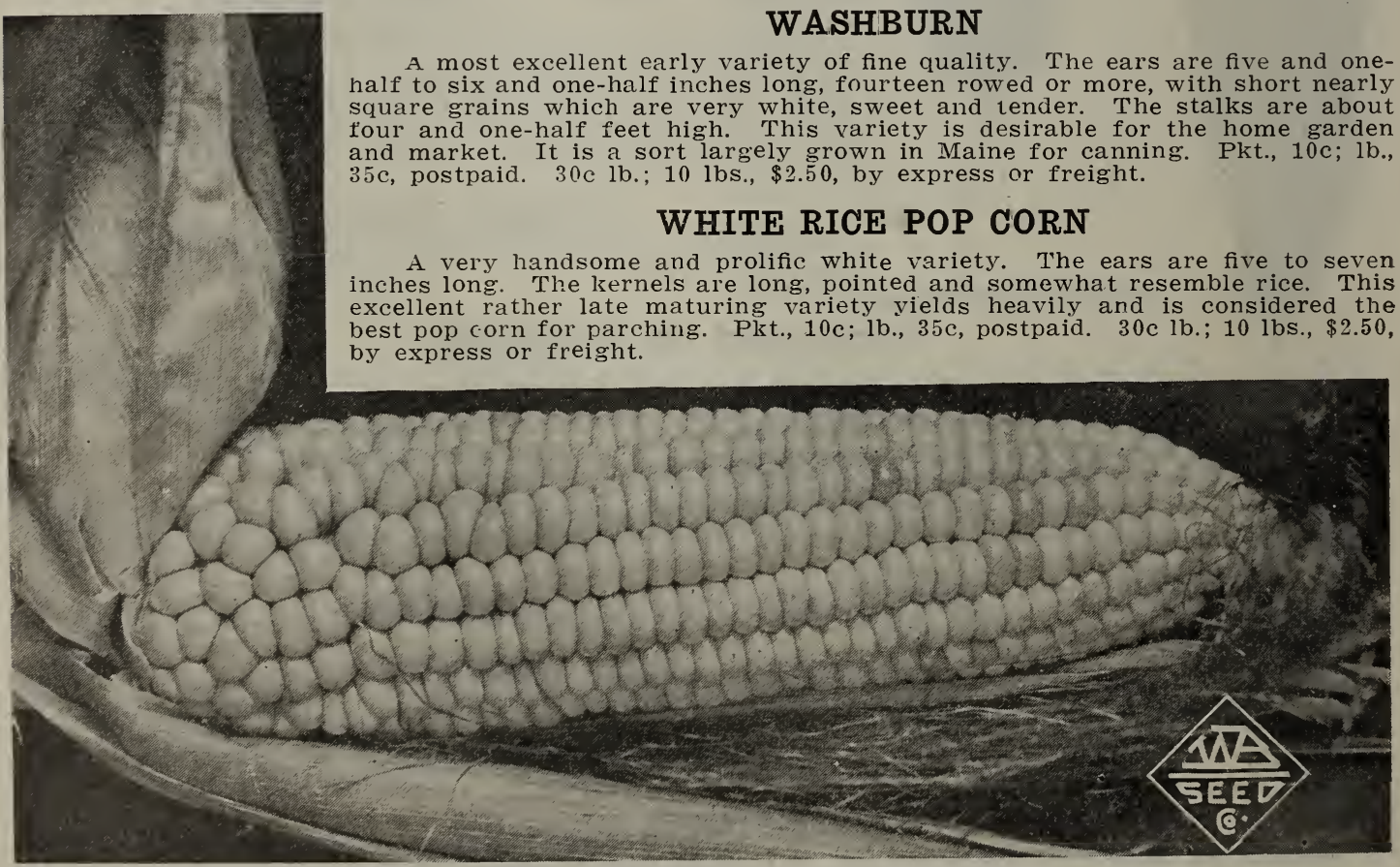

You'll like our GOLDEN BANTAM. Be sure and include some in your order Page 18 
You will derive pleasure, health and profit from a Vegetable Garden

\section{CUCUMBERS}

Culture-One ounce of seed will plant 50 hills; 3 lbs., to the acre. Matures from 36 to 50 days. For early use, plant as soon as the ground is warm, in hills 4 to 6 feet apart each way. 8 to 10 seeds in a hill. Cover half inch deep. When danger of insects is past, thin out the plants, leaving 5 or 6 of the strongest in each hill.

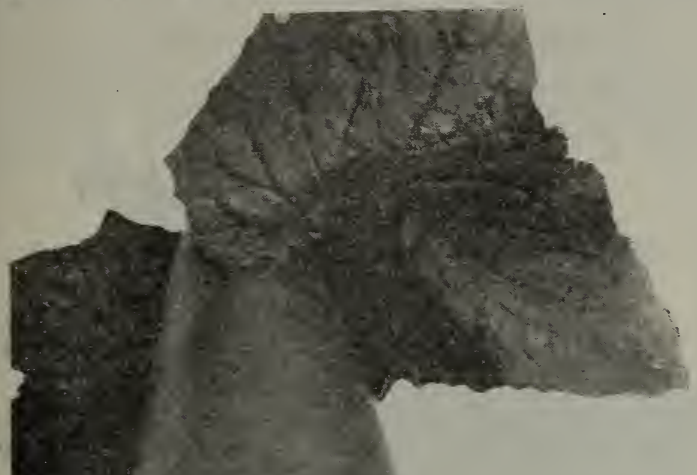

IMPROVED LONG GREEN.

Grows 10 to 12 inches long, but makes fine picisles when young; the full sized fruits are best for sweet pickles and slicing. Dark green in color. firm and crisp; quality excellent. A great bearer. Plit., 5c; oz., 20c; 1/4 lb., 35c; lb., $\$ 1.00$.

\section{DAVIS' PERFECT.}

A type of White Spine which is certain to meet with favor either for forcing or open ground culture. It is a handsome, extra long Cucumber, delightfully flavored, and retains its deep glossy green color until near maturity. Pkt., 5c; oz., $20 \mathrm{c}$; $1 / 4$ lb., $35 \mathrm{c} ; 1 \mathrm{~b} ., \$ 1.00$

\section{COOL AND CRISP}

A fine garden Cucumber, deep green and crisp. It is of the White Spine type. Very prolific. Pkt. $5 \mathrm{c} ;$ oz., $20 \mathrm{c} ; 1 / 4 \mathrm{lb} ., 35 \mathrm{c}$; lb., $\$ 1.00$.

IMPROVED ARLINGTON WHITE SPINE.

The advantages claimed for this variety are improvement in shape, color, earliness and shipping qualities. Plit., 5c; oz., 20c; $1 / 4$ lb., 35c; 1b., $\$ 1.00$

\section{WEST INDIA GHERKIN.}

The only genuine Gherkin. Small, oval, covered with spines; light green. For pickling exclusively. Pkt., 5c; oz., 20c; $1 / 41 \mathrm{~b}$., $35 \mathrm{c} ; 1 \mathrm{~b} ., \$ 1.00$.

\section{JAPANESE CLIMBING.}

A real climber. Comes into bearing quickly and sets its fruit constantly throughout the season. The fruit is of extra quality and a dark green color. A prolific yielder and a desirable table variety. Plit., 10c; oz., $40 \mathrm{c} ; 1 / 4$ lb., $\$ 1.50$.

\section{BOSTON PICKLING.}

Short, smooth and pointed; bright green; great yielder; one of the best for pickling. Pht $5 \mathrm{c}$; oz., $20 \mathrm{c}$; $1 / 4$ lb., $35 \mathrm{c}$; lb., $\$ 1.00$.

\section{SNOW'S PICKLING.}

Is the most popular pickle variety in use about Chicago. Medium sized, dark green. Pkt., $5 \mathrm{c}$; oz., $20 \mathrm{c}$; $1 / 4$ lb., $35 \mathrm{c}$; $1 \mathrm{~b} ., \$ 1.00$.

\section{EARLY SHORT GREEN, OR EARLY FRAME.}

A very desirable variety for either pickling or table use. Fruit straight, small at each end; bright green. Pkt., 5c; oz., 20c; $1 / 4$ lb., $25 \mathrm{c} ; 1 \mathrm{~b}$., $\$ 1.00$.

\section{CHERVIL-Curled.}

Very finely curled, resembling parsley; used in soups and salads. Pkt., 5c; oz., 20c; $1 / 4$ lb., 35c; lb., . 1.00 .

\section{CHICORY-Large Rooted}

Used as a substitute for coffee; and the young blanched shoots for salad. Pkt., $10 \mathrm{c}$; oz., $50 \mathrm{c}$; $1 / 4$ lb., $\$ 1.50$; lb., $\$ 4.50$.

\section{CHIVES.}

Has a mild flavor of young onions, and is used in soups and salads. Pkt., 10c; oz., $50 \mathrm{c}$, postpaid.

\section{COLLARDS.}

A loose form of cabbage grown in the South for greens. Not adapted to the North. Pirt., $5 \mathrm{c}$; oz., $20 \mathrm{c} ; 1 / 4$ 1b., $35 \mathrm{c} ; 1 \mathrm{lb} ., \$ 1.00$

\section{CORN SALAD.}

A small, quick growing salad plant for late fall, winter and spring use. The leaves are used as a substitute for lettuce and spinach. Plet., 5c ;nz., $20 \mathrm{c}$; $1 / 4$ lb., $35 \mathrm{c}$; lb., $\$ 1.00$.

\section{CRESS-Curled Cress, or Pepper Grass.}

The leaves are frilled and curled, crisp and pungent, and are used in salads and for garnishing meats. Pkt., 10c; oz., 20c; $1 / 4$ lb., $50 \mathrm{c}$; $1 \mathrm{~b} ., \$ 1.50$.

\section{Water Cress.}

A distinct variety of cress with small, oval leaves which are A dor salad It must be grown in shallow water, or the seed scattered along the banks of streams or ponds. Pkt., 10c; oz., $35 \mathrm{c} ; 1 / 4 \mathrm{lb} ., \$ 1.00$. 


We want your trade
We'll surely please you

\section{EGG PLANT}

Should be started under glass early in March and set out early. Does well in some localities.

NEW YORK IMPROVED SPINELESS.

Grows to a very large size, very prolific and fine flavored. Pkt., 10c; oz., 50c.

\section{ENDIVE}

A salad vegetable which is becoming valuable for winter use. Best after few frosts.

\section{LARGE GREEN CURLED.}

Leaves are quite broad, beautifully curled and form large flat heads which bleach readily to a creamy white. Pkt., 5c; oz., 20c; 1/4 1b., 35c; 1b., $\$ 1.00$.

\section{WHITE CURLED.}

(Self-blanching.) Leaves pale green, grows to a large size, always crisp and very tender: Pkt., $5 \mathrm{c} ;$ oz., $20 \mathrm{c} ; 1 / 4$ lb., $35 \mathrm{c} ; 1 \mathrm{~b} ., \$ 1.00$.

\section{FLAT LEAF.}

Leaves broad, light green, nearly plain, used in stews and soups; but if the leaves are tied up it will blanch nicely and can be used as a salad. Pkt., 5c; oz., 20c; $1 / 4$ lb., $35 \mathrm{c} ; 1 \mathrm{~b} ., \$ 1.00$.

\section{WITLOOF CHICORY or FRENCH ENDIVE.}

Witloof is used as a winter salad. The seed should be sown in open ground not later than June. Roots are to be lifted in fall and stored in a cool place until wanted for forcing, when they are to be planted about $1 \frac{1 / 2}{2}$ to 2 inches apart in trench 18 inches deep Fill in with light soil. Pkt., 10c; oz., 30c; $1 / 4$ 1b., $\$ 1.00$.

\section{GARLIC}

A medium loam soil containing a little sand and well-drained is best and commercial fertilizer should be used. Deep and thorough preparation of the soil is necessary. $1 / 4 \mathrm{lb}, 20 \mathrm{c}$; lb., $50 \mathrm{c}$.

\section{KOHL RABI}

A plant forming a firm bulb above the ground and bearing short leaves. The bulb is the edible part and when cooked tastes similar to turnips.

\section{EARLY WHITE VIENNA.}

The most desirable variety for general use. Pkt., 5c; oz., 30c; 1/4 lb., $\$ 1.00$.

\section{EARLY PURPLE VIENNA.}

Leaves and bulb have a bright purple color but flesh is white and fine. Pkt 5c; oz., $30 \mathrm{c} ; 1 / 4 \mathrm{lb}$. $\$ 1.00$.

\section{GOLIATH OR STOCK}

This is a large variety, usually grown for stock feeding, although young bulbs are of good quality for table use before they become hard. Seeds can be drilled thinly in rows where the plants are to grow, and thinned out to stand six inches apart. On approach of winter they may be taken up, roots and leaves removed, and stored like turnips. Pkt., $10 \mathrm{c}$; oz., $25 \mathrm{c}$; $1 / 4 \mathrm{lb}$., $75 \mathrm{c}$.

\section{KALE OR BORECOLE}

A species of Cabbage, forming a mass of leaves The leaves are cooked as greens. Should be planted late, as the cold weather improves it. It is hardy and will withstand cold weather.

\section{TALL GREEN CURLED SCOTCH.}

Heads are formed on stalks two and a half feet high. Color bright green and leaves are exceedingly curly. Pkt., 5c; oz., 30c; $1 / 41 \mathrm{~b} ., 75 \mathrm{c}$.

\section{DWARF GREEN CURLED SCOTCH.}

Noted for its extreme hardiness, dwarf, compact habit and extra fine curled leaves. Pkt., $5 \mathrm{c}$; oz., $30 \mathrm{c} ; 1 / 4$ lb., $75 \mathrm{c}$.

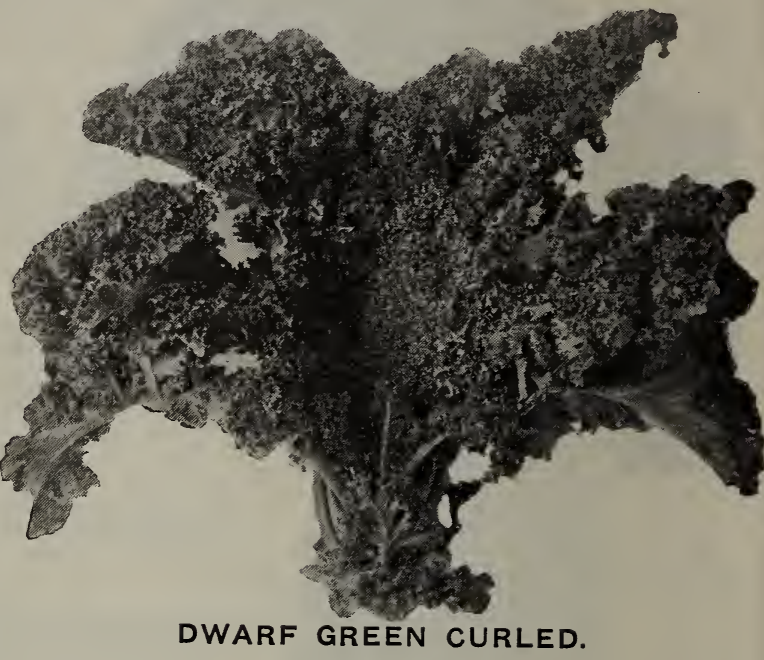

THOUSAND HEADED KALE.

Is almost indispensable as a green feed for stock and poultry through the winter. The plants are hardy and thrifty, producing a heavy tonnage per acre and may be left in the field until wanted for feed. It is an ideal feed for dairy cows. One pound will produce sufficient plants for one acre. Pkt., 10c; lb., 50c.

\section{LEEK}

Culture of Leek is about the same as onions. Sow either in early fall or spring. Sow in beds or drills, when 6 inches high, transplant in rows. setting as deep as possible without covering center leaves. Four pounds to plant an acre.

\section{LARGE LONDON FLAG.}

The oldest and best-known and most largely grown variety. Pkt., $10 \mathrm{c}$; oz., $30 \mathrm{c}$ : $1 / 4 \mathrm{lb}$., $\$ 1.00$.

\section{MUSTARD}

The fresh leaves are used largely as a salad or for boiling "Greens" in the Southern States during the fall and winter months. The seed should be sown thinly in drills on the approach of cool, moist weather in the fall.

\section{MUSTARD, WHITE LONDON.}

Considered the best for salads and spinach; leaves light green. It is best when about 4 inches high. Pkt., 5c; oz., 20c; $1 / 4$ 1b., $35 \mathrm{c}$.

\section{SOUTHERN GIANT, CURLED.}

This is grown extensively in the South, wher it is highly esteemed. Pkt., 5c; oz., 20c; $1 / 41 \mathrm{~b}$. . 
All plants need fertilizer It always pays

\section{LETTUCE}

Lettuce is represented by four distinct classes or types-by the thick-leaved, smooth-edged cab-

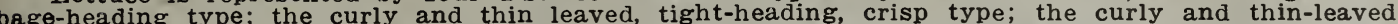
bunch or non-heading type, and the Cos or celery type. There are early, medium early and late varieties of each type, as well as those especially adapted for greenhouse, hotbed, winter, spring, summer and autumn uses. There is so great a difference in localities in regard to the value of lettuce, that uniform rule of culture cannot be adopted. For the ordinary house garden, it is desirable to use 作 should be planted in rows eighteen inches apart, as early as possible, and the young plants of cabbage varieties should be thinned to 6 or 8 inches apart. Varieties that do not head may be left quite thick, and thirined out as used. See following page.

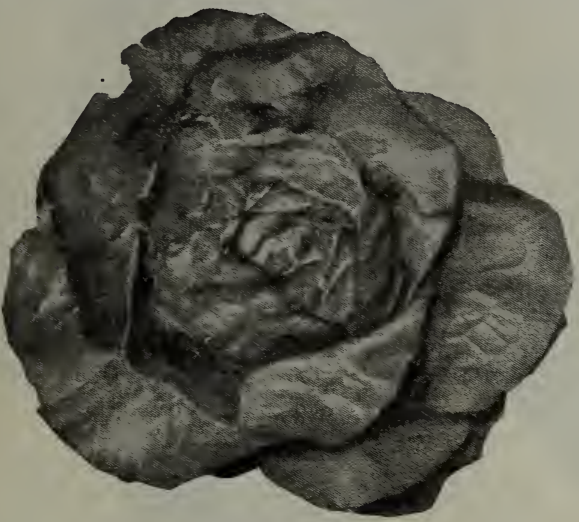

BIG BOSTON.

(White Seed.) Resembles Boston Market, but nearly twice as large: desirable for forcing and spring and fall outdoor planting. Pkt., 5c; oz., $20 \mathrm{c} ; 1 / 4$ lb., $50 \mathrm{c}$.

\section{BLACK SEEDED SIMPSON.}

A cutting variety of unusual merit. Pkt., 5c; oz., 20c; $1 / 4$ lb., $50 \mathrm{c}$

\section{EARLY CURLED SIMPSON.}

A loose-bunching sort forming no definite head. Is crisp and tender; light green in color. Is very hardy and easy to grow. Pkt., 5c; oz., $20 \mathrm{c}$; $1 / 4 \mathrm{lb}$., $50 \mathrm{c}$.

\section{CALIFORNIA CREAM BUTTER.}

A splendid variety for summer. It produces a very large and white head. It will stand extreme heat and is slow to go to seed. Pkt., $10 \mathrm{c}$; oz., $20 \mathrm{c}$; $1 / 4$ lb., $50 \mathrm{c}$.

\section{GRAND RAPIDS.}

The well-known forcing variety for the Middle West, where butter-headed or cabbage varieties do not grow well under glass. Is a loose-bunching variety, forming no definite head. Is extremely curly, and its light yellowish-green color makes it very attractive. Pkt., $5 \mathrm{c}$; oz., $20 \mathrm{c} 1 / 4 \mathrm{lb}$., $50 \mathrm{c}$.

\section{HANSON.}

A fine large-heading variety. Leaves curled on the edges; light yellowish-green in color. The head is crisp and brittle and flavor excellent. Is the very best house garden variety in existence. and much the finest variety of its class. Hanson is similar to the famous Los Angeles lettuce listed below, but is larger and lighter green: an extra fine sort. 4110 w 12 inches for each head. Pkt., 5c; oz., 20c; $1 / 4$ lb., $50 \mathrm{c}$.

NEW YORK OR WONDERFUL.

One of the largest varieties grown. The heart blanches beautifully and is crisp, tender and delicious. It is robust-growing, roots deeply and is thus able to resist hot dry weather: is slow to run to seed, and a sure header. The outer colnr is a distinct apple-green. It has been extensivelv grown in all sections of the country and as a standard summer Lettuce it is in every way desirable. Plit., 10c; oz., :5c $11,1 \mathrm{~b} ., 75 \mathrm{c}$.
ICEBERG-(White Seed).

(White Seed.) A curly lettuce, large, solid heads. The outer leaves are light green in color and their habit of branching towards the center of head is a great aid to the blanching of heart. Pkt., 5c; oz., 20c; $1 / 4$ lb., $50 \mathrm{c}$

\section{PRIZE HEAD.}

One of the very best loose-bunching or loose head varieties. It is the most easily grown variety in cultivation. Pkt., 5c; oz., 20c; $1 / 4 \mathrm{lb}$., $50 \mathrm{c}$.

\section{EARLY TENNIS BALL.}

The plant is small, of rapid growth, and should be used as soon as large enough, as it quickly runs to seed. Leaves dark green, thick and crisp. One of the best for growing under cover, and for forcing. Pkt., 5c; oz., 20c; $1 / 4$ lb., $50 \mathrm{c}$.

\section{COS OR CELERY LETTUCE.}

The Cos Lettuce or Salad Romaine is of distinct upright growth and esteemed for its fresh crispness and mild flavor. It is grown in the northern states during the late spring and early summer; throughout the Gulf Coast States it is grown for use during the cool early spring months. Pkt., 5c; oz., $20 \mathrm{c}$; $1 / 4$ lb., $50 \mathrm{c}$.

\section{MUSKMELON}

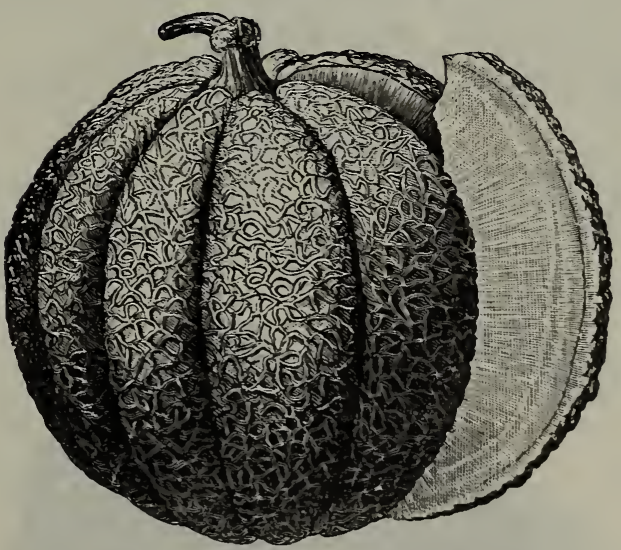

WELL-KNOWN VARIETIES

Rocky Fordl or Netted Gem. Pkt. 5c; oz., 20c. Jenny Lind. Pkt., $5 \mathrm{c}$; oz., $20 \mathrm{c}$.

Early Hackensack. Pkt., 5c; oz., $20 \mathrm{c}$.

Milers Cream. Pkt., 5c; oz., $20 \mathrm{c}$.

Casaba Melon. Pkt., 5c; oz., $20 \mathrm{c}$.

Citron Melon. Pkt., 5c; oz., 20c.

\section{WATERMELON}

Georgia Rattlesnake. Pkt., 5c; oz., $20 \mathrm{c}$. Sweetheart Pkt. 5c; oz, 20c.

Cuban Queen. Pkt., 5c; oz., $20 \mathrm{c}$

\section{Head Lettuce should be transplanted to get the best results. Some commercial} fertilizer should be used. 
Do not trust to luck in ordering seeds-Ours are tested

\section{MUSHROOMS}

\section{LAMBERT'S MUSHROOM SPAWN.}

The white thread-like substance seen permeating the brick or tablet in which Mushroom Spawn is sold is called Mycelium. The edible part of the Mushroom is analogous to the flower in other plants. The spawn as sold is in a dormant condition, growth being suspended by withholding moisture. The task for the grower is to cause it to revive and resume growth. This is accomplished by placing the spawn in prepared beds of fresh horse manure and soil, which may be made in a shed, cellar, or under greenhouse benches. Next to proper preparation the most important thing is to maintain a uniform and moist air temperature of 50 to 60 degrees. Full directions given in pamphlet, free if asked for.

Lambert's Pure Culture Spawn, always fresh, full description as to how to plant, upon request. $35 \mathrm{c}$ per

brick; 3 for $\$ 1.00$, not postpaid.

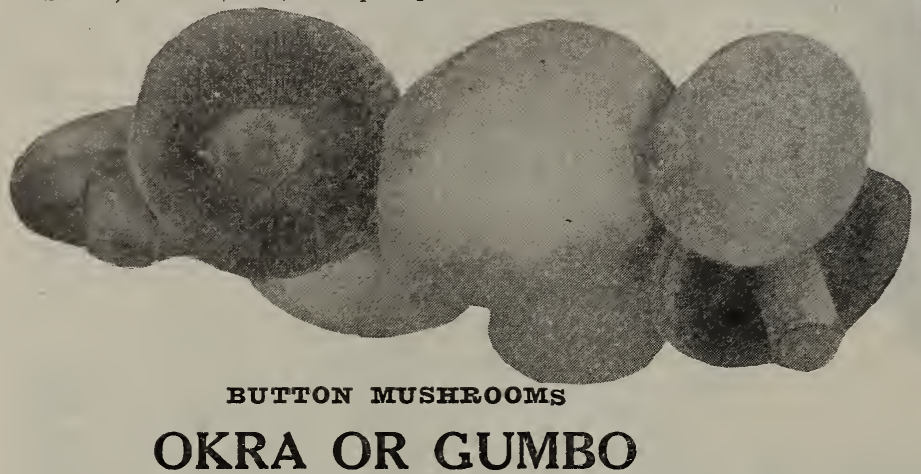

The pods of this plant are regarded as a household necessity in the Southern States, and are popular for soups also in the North.

DWARF PROLIFIC. $20 \mathrm{c}$

Dwarf stocky growth, prolific and early. Pkt., 5c; oz.,

WHITE VELVET.

Of tall growth, with long pods which are round, smooth, and of a velvety white coloring. Pkt., $5 \mathrm{c}$; oz., $20 \mathrm{c}$

\section{PEPPERS}

Sow the seeds early in hotbeds; or later, when the weather becomes warm, in open beds. When two or three inches high, transplant to a warm, mellow soil, in rows eighteen inches apart and a foot apart in the rows. Guano and hen manure are excellent fertilizers and will greatly increase the yield.

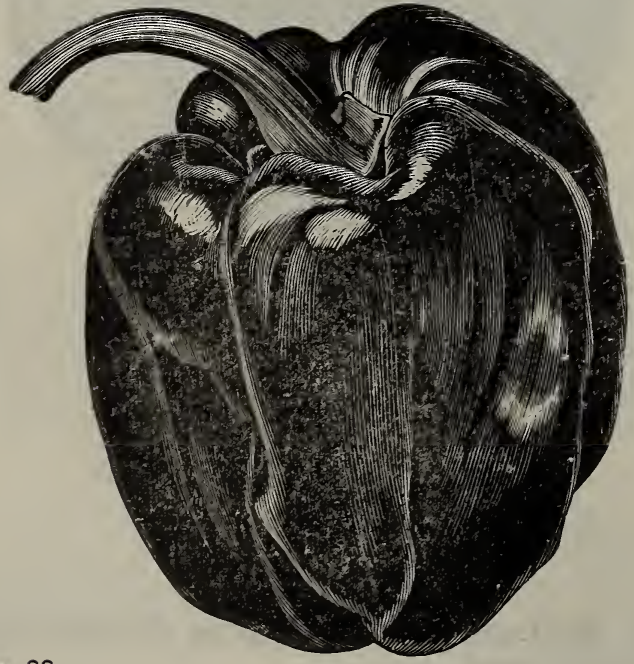

Page 22

\section{PARSNIPS}

About 8 pounds to plant an acre.

The seed is very slow to germinate and should be sown early in the spring in rows 18 inches apart for hand cultivation, or 30 inches apart for horse cultivation. Thin out to 6 inches in the row. Cultivate often. 
Order early-All stock will be short this year

\section{O N I O N S}

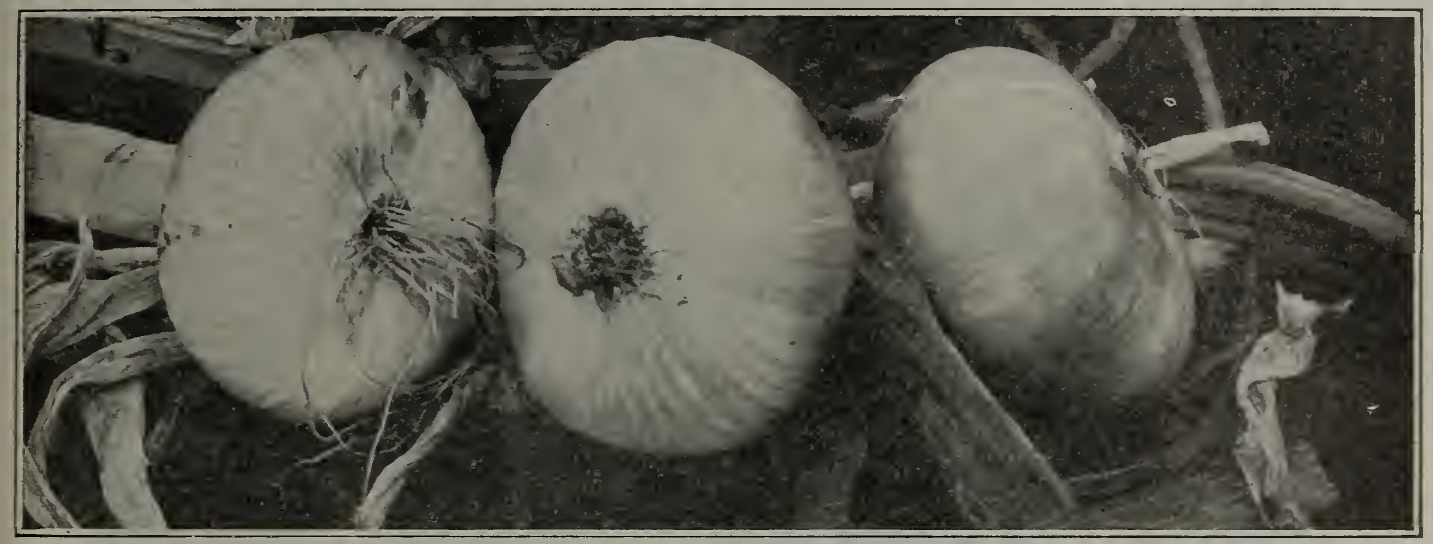

\section{ONIONS-CULTURE}

One ounce will sow 100 feet of drill.

Sow in spring as soon as the ground can be worked, in drills one foot apart. Thin to 3 or 4 inches and cultivate frequently with rake and hoe to keep down the weeds. They grow best in rich, sandy soil.

\section{WHITE ITALIAN TRIPOLI}

A large, globe-shaped onion, with clear white skin and pearl-white flesh. Of mild, sweet flavor. Not a good keeping onion, but much esteemed as a garden sort. Pkt., 5c; oz., 35c; 1/4 lb., \$1.00; lb., $\$ 3.00$.

WHITE PORTUGAL, OR SILVER SKIN

This variety is one of the leading white sorts, and is of beautiful shape and very mild flavor. The bulbs are flat in shape and mature early. It is a splendid variety for both family and the market gardener, and is very largely used for growing sets on account of its fine shape when small, and also for its good keeping qualities. Pkt., 5c; oz., $35 \mathrm{c} ; 1 / 4 \mathrm{lb}$., $\$ 1.00$; lb., $\$ 3.00$.

\section{WHITE GLOBE}

Yields abundantly and, as a table variety, its elear white color is exceptionally attractive. Pkt. oc; oz., 35c; 1/4 lb., \$1.00; lb., \$3.00.

\section{YELLOW GLOBE DANVERS}

This is the standard variety for winter use in our western markets, producing well-ripened bulbs averaging two inches in diameter and nearly globe-shaped. Skin a light golden brown or pale yellow; flesh pure white, crisp, and mild in flavor. The plants have very slender necks and the bulbs ripen uniformly. The name "Globe" in this connection must be taken comparatively, as the True Danvers Onion is never so perfectly globe-shaped as the Southport Yellow Globe. Pkt., 5c; oz., 30c; 1/4 lb., 75c; lb., \$2.50.

\section{YELLOW FLAT DANVERS}

(Flat.) The best known and most generally used flat yellow onion. Bəst for garden use. Easily grown and a big producer. Pkt., 5c; oz. $30 \mathrm{c}$; $1 / 4$ 1b., $75 \mathrm{c}$; 1b., $\$ 2.50$.

\section{AUSTRALIAN BROWN}

An early and hardy variety which does especially well in this state. Should be planted early, on low, wet grounds to get large bulbs. The skin is thick and the color is a rich brown. Is especially noted as a long keeper, as it keeps well into spring and much longer than other varieties. Pkt., $5 \mathrm{c}$ : oz., $30 \mathrm{c}$; $1 / \mathrm{s}$ lb., $75 \mathrm{c}$; 1b., $\$ 2.5 .0$.

\section{WHITE BARLETTA}

A very early variety with pure white skin. In shape it is flat and is unsurpassed for home-made pickles. Pkt., $10 \mathrm{c}$; oz., $40 \mathrm{c}$; $1 / 4$ lb., $\$ 1.25$; lb., $\$ 4.00$.

\section{PRIZETAKER}

An onion of the largest size and nearly globular in form. Skin is yellowish brown; flesh is white, mild and tender. It is one of the best of the large European sorts. If started very early in hotbeds, it will produce a mammoth onion the first season. Pkt., 10c; oz., 35c; 1/4 lb., \$1.00; lb., \$3.00.

\section{SOUTHPORT RED GLOBE}

Of medium size, spherical, with small neck, very deep, rich red color and of superior quality. Pkt., $5 \mathrm{c}$; oz., $30 \mathrm{c}$; $1 / \frac{1}{\mathrm{t}}$ 1b., $75 \mathrm{c}$; $1 \mathrm{~b} ., 2.50$.

\section{LARGE RED WETHERSFIELD}

The best keeper and one of the most popular for general cultivation. Large size, deep purplish red skin. Pkt., $5 \mathrm{c}$; oz., $30 \mathrm{c}$; $1 / 1 / \mathrm{lb}$., $75 \mathrm{c}$; 1b., $\$ 2.50$.

\section{WHITE QUEEN}

A very early white onion. Rather small and does not keep well. Is of fine mild flavor, and largely used for home-made picklees. Pkt., 5c; oz., 3 כुc; $1 / 4$ lb., $\$ 1.00$; lb., $\$ 3.00$.

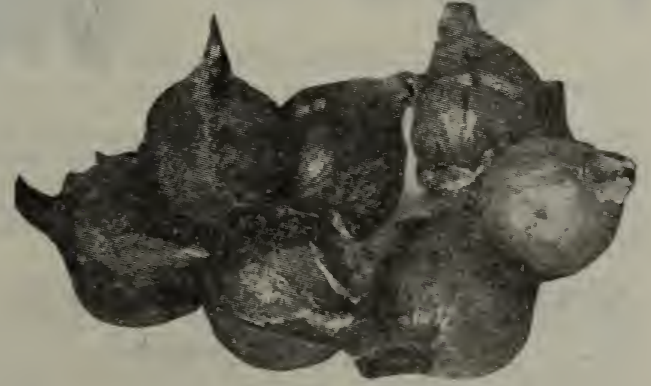

\section{ONION SETS}

YELLOW ONION SETS. Lb., 25c; 10 lbs., \$2.25 postpaid.

SHALIOT OR MULTIPIIER. Lb., $35 \mathrm{c}$.

Get prices from Specials. 


Our experience is at your servlos
Write us

150 to $200 \mathrm{lbs}$. are required to the acre. The smooth varieties are the hardiest and should be planted first. The seed is usually sown thickly in double rows, and these double ruws, constituting one row, should be about $31 / 2$ to 4 feet apart. Cuver seed 2 or 3 inches, and if too thick, thin to about $1 \frac{1}{2}$ to 2 inches. Cultivate often, especially in dry weather. A thick stand is desirable. It is not necessary to provide supports for the $\mathrm{d}$ warf corts. Peas grow fairly well on poor soils, but a little fertilizer will greatly increase the yield. Well-rotted stable manure in the drill is splendid, but fresh manure should be avoided unless it is broadcasted.

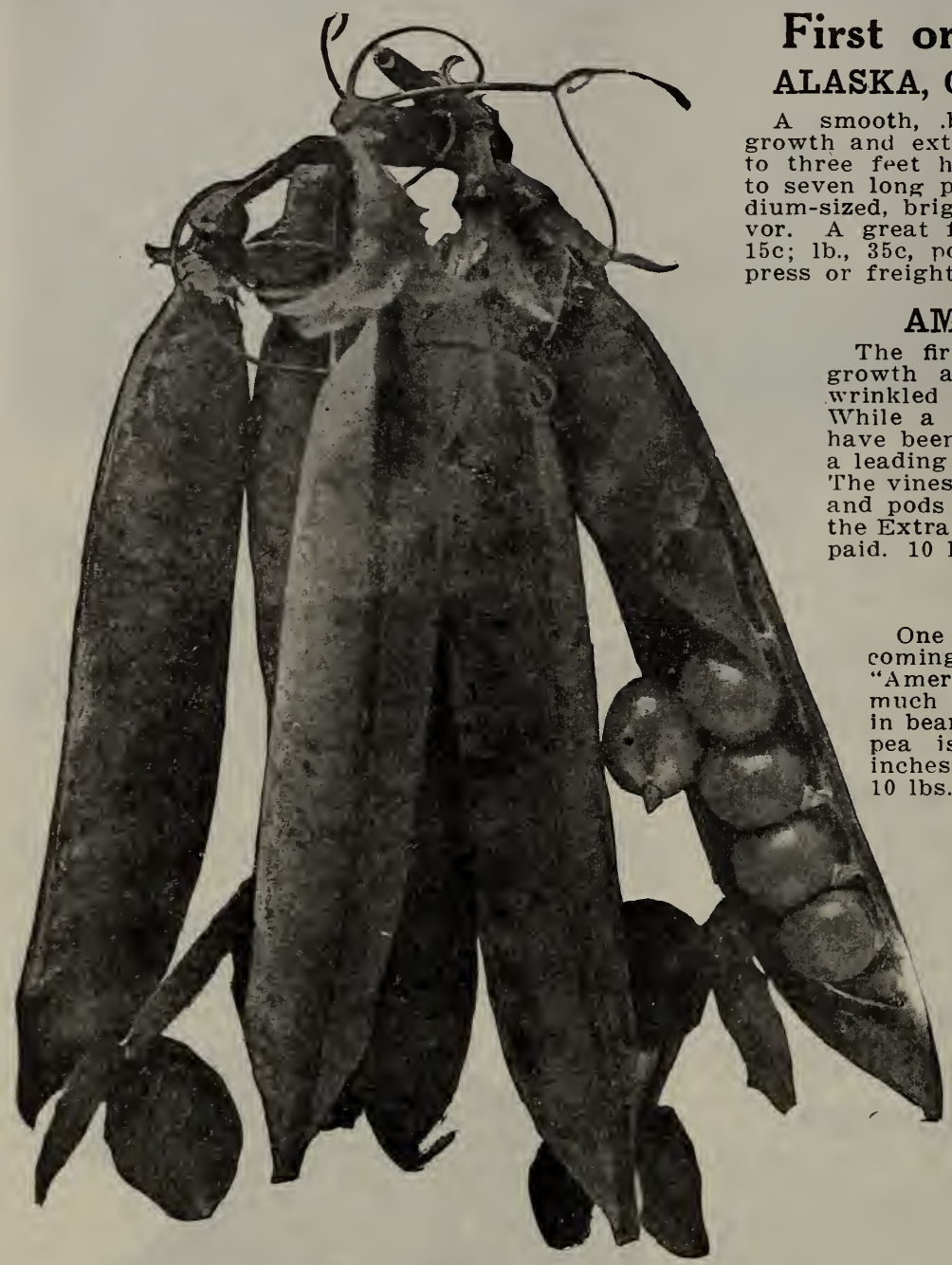

\section{First or Early Varieties}

ALASKA, OR EARLIEST OF ALL

smooth, .blue pea, of even, vigorous extra early maturity. Vines two feet high, unbranched, bearing four dium-sized, bright green peas of excellent flavor. A great favorite with our market gar$15 \mathrm{c}$; $1 \mathrm{~b} ., 35 \mathrm{c}$, nostraid. 10 lbs., $\$ 2.75$, by express or freight.

\section{AMIERICAN WONDER}

first variety of dwarf, compact arly maturity, having a rinkled seed and rich, sweet flaror. number of improved varieties been introduced, this still remains The vines grow only 8 to 10 inches high. and pods mature in quick succession to the Extra Early. Pkt., $15 \mathrm{c}$; 1b., $35 \mathrm{c}$, postid. 10 lbs., $\$ 2.75$, express or freight.

\section{PREMIUM GEM}

One of the earliest dwarf varieties, coming in a little later than the "American Wonder:" grows taller, much more productive and continues $n$ bearing longer. The quality of the pea is very superior. Height, 15 inches. Pkt., 15c: 1b., 35c, postpaid. 0 lbs., $\$ 2.75$, by express or freight.

\section{LAXTONIAN}

This is an ideal market and home garden pen, medium divarf in habit of growth, but with very large pods, averaging 5 to 6 inches in length. Laxtonian seldom has any blank spaces in the pods. Per pkt., $15 \mathrm{c}$; $1 \mathrm{~b} ., 35 \mathrm{c}$, postpaid. $101 \mathrm{bs}$. , $\$ 3.00$, by express or freight.

\section{MAIN CROP VARIETIES} DWARF TELEPHONE

A heavy cropper, bearing uniform. long. straight, square-ended, dark green pods, containing 7 to 8 large, rich-flavored peas of a deep green color, adding to their attractiveness when served. Almost as early as the extra-early smonth po:s : 3 feet high. Pkt., $15 \mathrm{c}$; 1b., $35 \mathrm{c}$, postpaid. $10 \mathrm{lbs}$., $\$ 2.50$, by express or freight.

\section{BLUE BANTAMI}

Extremely early, "Blue Bantam" excels in the size of pods and quality of the sweet large dark green Peas with which they are filled, and is said to surpass all extra early divarf varieties in yield. Very dwarf and hardy. Pkt., $15 \mathrm{c}$; $1 \mathrm{~b} ., 35 \mathrm{c}$, postpaid. 10 lbs., $\$ 3.00$, by express or freight.

\section{GRADUS OR PROSPERITY}

An extra early sort. Pods large as Telephone: very showy, green peas most luscious. Vine a little stronger than Alaska. Just now this vari. ety is all the rage. No stock is better than that we offer. Height, 3 feet. Pkt., 15c; 1b., $35 \mathrm{c}$, postpaid. $10 \mathrm{lbs}$., $\$ 2.75$, by express or freight. 


Uir Nursery Trees Are Seleoted
Stook

\section{GARDEN PEAS-Continued}

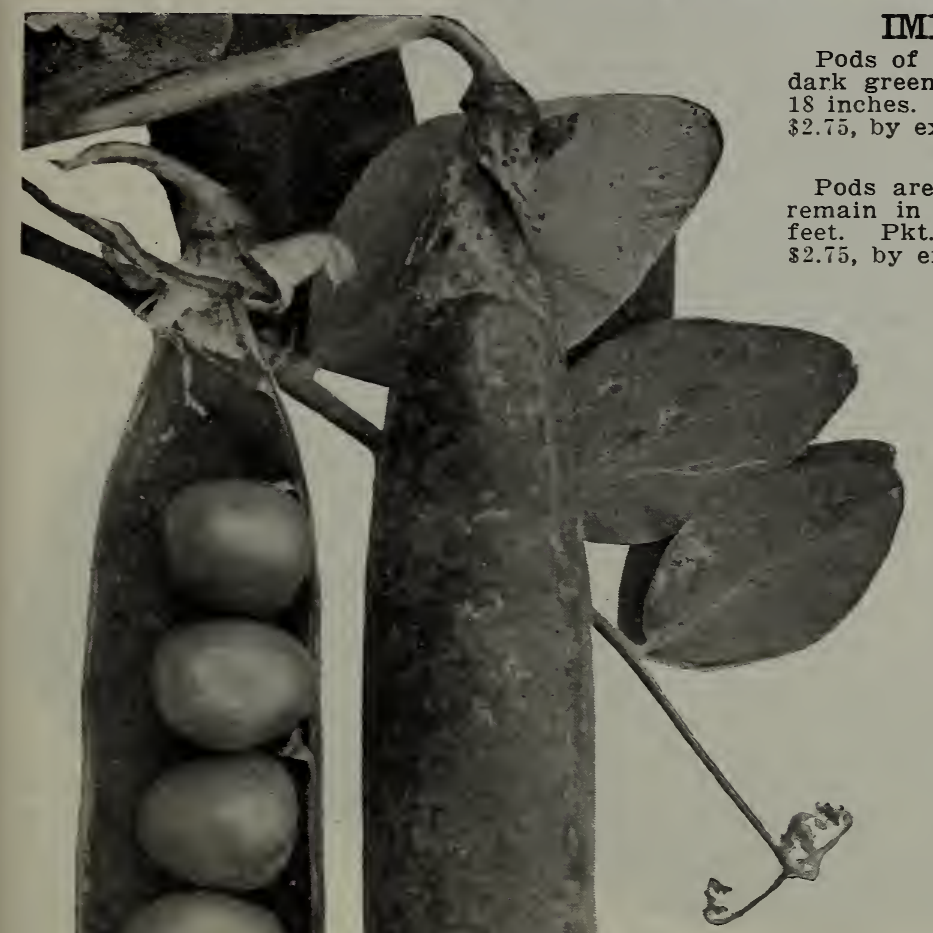

\section{IMPROVED STRATAGEM}

Pods of immense size, filled with very large 1s green peas of the finest quality; height, 32.75 , by express or freight.

\section{YORKSHIRE HERO}

Pods are well filled with large peas, which remain in good condition for a long time; 2 feet. Pkt., 15c; lb., 35c, postpaid. 10 lbs., $\$ 2.75$, by express or freight.

\section{TELEPHONE}

A tall, wrinkled, narrow variety, enormously productive and of fine quality. The pods are of the largest size and contain from six to seven large peas. Height, $4 \frac{1 / 2}{2}$ feet. Pkt., $15 \mathrm{c}$; lb., 35c, postpaid. $10 \mathrm{lbs}$., $\$ 2.75$, by express or freight.

\section{THOMAS LAXTON}

A fine, early tall variety, similar to Gradus, but more hardy and not quite so early. It is also a little darker in color and has large pods that fill well with peas of finest quality. Pkt., 10c; lb., $35 \mathrm{c}$, postpaid. 10 lbs., $\$ 2.75$, by express or freight.

\section{ALDERIMAN \\ SEE SPECIALS.}

\section{EDIBLE POD PEAS MIELTING SUGAR}

A great favorite with those who have once used them. Plants grow 5 feet high, producing handsome large pods; when cooked resemble wax beans. Pkt., $15 \mathrm{c}$.

\section{DWARF GRAY SUGAR}

A distinct variety with edible pods. Plants growing 2 feet high with an abundance of medium size pods. Pkt., $15 \mathrm{c}$; 1b., $35 \mathrm{c}$, postpaid.

\section{SOUP PEAS}

\section{YELLOW MARROWFAT}

Known also as Swedish Peas, a dry pea of great merit. Lb., $25 \mathrm{c}$, postpaid. 10 lbs., $\$ 2.00$, by express or freight.

\section{YELLOW CANADIAN}

Few people realize the great food value of this class of pea. It is equally as good as the bean and can be used in quite as many ways. It is chiefly used in pea soup. A few pounds will produce all that are required in an ordinary family. Lb., $15 \mathrm{c}$, postpaid. 10 lbs., $\$ 1.25$, by express or freight.

IMPROVED STRATAGEM.

\section{BLUE BELLS}

This is also a soup pea of a higher quality and should be planted to help cut down the high cost of living. An immense yield can be expected and the peas are very easily taken care of. Lb., $20 \mathrm{c}$, postpaid. $10 \mathrm{lbs}$., $\$ 1.50$, by express or freight.

\section{Succession Collection of Peas}

Plant these varieties all the same day. You will have a supply of peas from spring until late summer, which makes a successive collection-Early Alaska, American Wonder, Gradus, Dwarf Telephone; a pkt. of each of these four peas for 50c. 


\section{POTATOES}

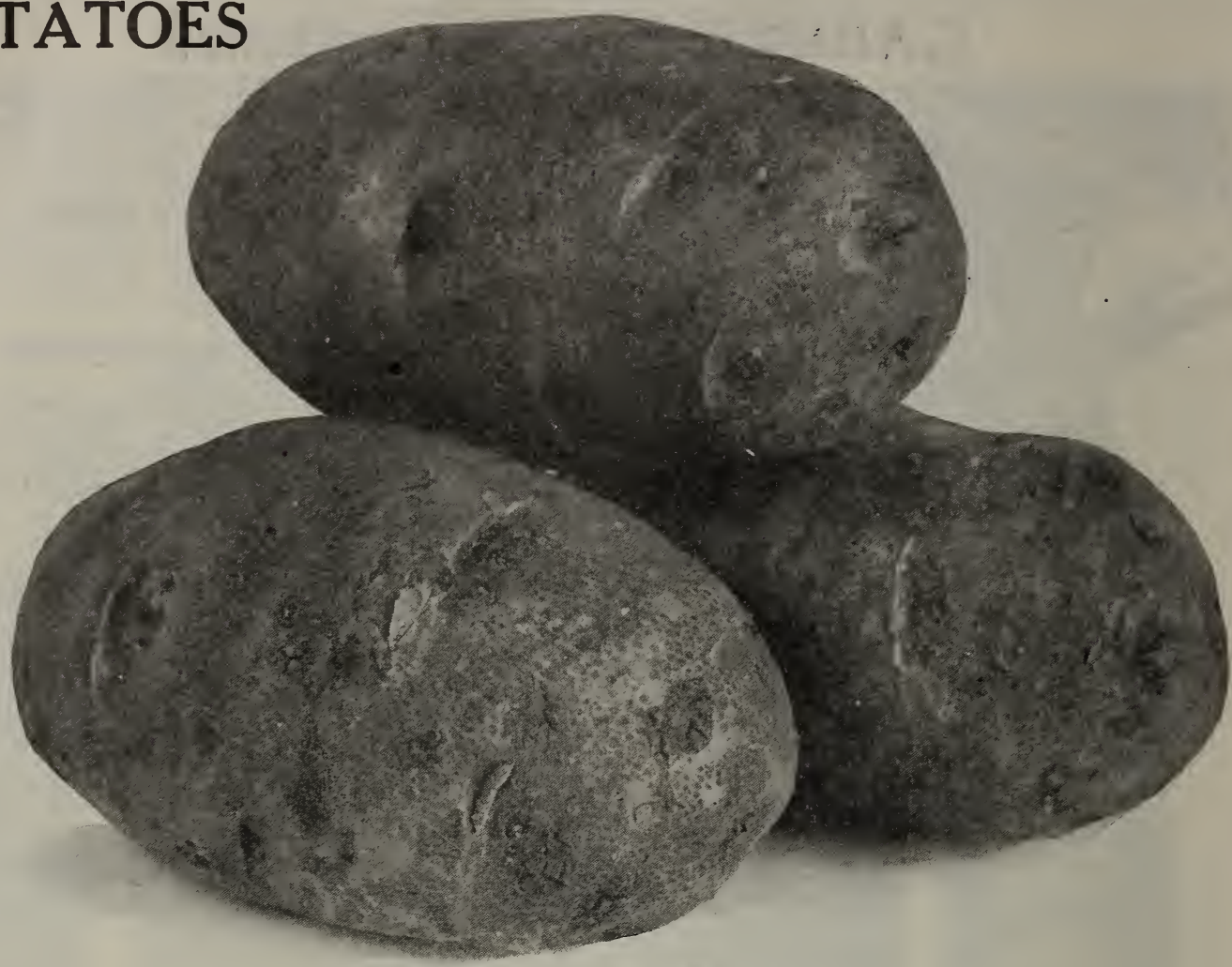

\section{IRISH BEAUTY}

WE HAVE HAD PRACTICALLY ALL OUR SEED POTATOES GROWN BY CONTRACT THIS YEAR AND WILL BE ABLE TO FURNISH SOME EXTRA SELECTED STOCK.

We are predicting great things for this wonderful potato, for we have thoroughly tried it out and can most heartily recommend it. For a main crop late potato we have never seen its equal. It is clean-looking, of fine size and shape and a great producer.

Price by mail, postpaid in 1 st, 2 nd and 3 rd zones... 4 lbs.

By Freight or Express, not Prepaid.-...

$\$ 0.40$

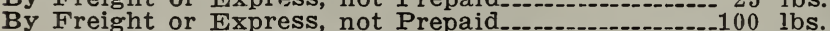

2.00

send out are seed potatoes in every sh They seed potatoes we send out are seed potatoes in every sense that the word seed should impig. at any price. To that end they will be hand sorted, selected stock such as anyone will be proud to plant.

\section{EARLY VARIETIES}

\section{AMERICAN WONDER}

American Wonder Potato was first offered nine years ago and is the best main crop potato for Western Washington. During these years we have distributed it to many sections of the United States, always receiving splendid reports, and up to the present time have yet to find a variety combining so many desirable qualities. Lb., $10 \mathrm{c} ; 25$ lbs., $\$ 2.00 ; 100$ lbs., $\$ 5.50$.

\section{EARLY OHIO}

A Week Earlier Than Any Large Red Skin Sort

A well-known favorite sort, producing its crop very early; a good yielder, and one of the finest varieties for the table. Its quality is excellent, cooking both dry and mealy. The light red color skin resembles Early Rose but grows more round-oblong in shape. An excellent winter keeper. Lb., $10 \mathrm{c} ; 25$ lbs., $\$ 2.00 ; 100$ lbs., $\$ 5.50$.

\section{IRISH COBBLER}

\section{A World Wide Favorite.}

It is a most excellent extra early variety, maturing good size tubers seven weeks from time of planting. It has also the remarkable characteristic of producing very few, if any, small potatoes, all the tubers being of marketable size. The vines make short, upright growth, so that the hills may bo only a short distance apart. The flesh is pure white, with a clean, smooth, white skin; and in quality they are excellent, always cooking dry and mealy. Splendid keepers. Lb., 10c; 251 lbs., $\$ 2.00 ; 100$ lbs., $\$ 5.50$. 


Our business is four times what it WOODRUFF
was three years ago

\section{POTATOES - Contd.}

\section{PURE EARLY ROSE.}

\section{An Old Standard Favorite Sort.}

Every farmer and gardener knows the old Early Rose potato, and nothing need be said in its favor. It has no faults, except that ill treatment and neglect sometimes cause a poor or weak strain to be put on the market under the name of Early Rose seed potatoes. We have been at great pains, therefore, to get a true, strong strain of Early Rose grown in the far North, for our stock, and we can offer it as the purest and best that can be had. Early Rose will never go out of fashion as long as the original stock can be obtained. Lb., $10 \mathrm{c} ; 25 \mathrm{lbs}$., $\$ 2.00 ; 100 \mathrm{lbs}$., $\$ 5.50$.

\section{SENSATION. See Specials.}

\section{GOLD COIN. See Specials.}

The following are the list of the Standard Varieties we have. All the stock has been selected true to name and free from scale, scab and other diseases:

\begin{tabular}{|c|c|c|c|}
\hline Earliest of All.. & $\begin{array}{l}\text { Lb. } \\
10 \mathrm{c}\end{array}$ & $\begin{array}{l}25 \text { Lbs. } \\
\$ 2.00\end{array}$ & $\begin{array}{r}100 \text { Lbs. } \\
\$ 5.50\end{array}$ \\
\hline Beauty of zebron & $10 \mathrm{c}$ & 2.00 & 5.50 \\
\hline Mortgage Iifter & $10 \mathrm{c}$ & 2.00 & 5.50 \\
\hline Burbank $\ldots \ldots$ & $10 \mathrm{c}$ & 2.00 & 5.50 \\
\hline Netted Gem ... & $10 \mathrm{c}$ & 2.00 & 5.50 \\
\hline Late Rose. & $10 \mathrm{c}$ & 2.00 & 5.5 \\
\hline Puritan .. & $10 \mathrm{c}$ & 2.00 & 5.50 \\
\hline White Elephant & $10 \mathrm{c}$ & 2.00 & 5.50 \\
\hline
\end{tabular}

\section{SWEET POTATO PLANTS}

You can grow sweet potatoes easily if you plant the right varieties and set them out after the ground is warm. Rich sandy bottom land is best, but any good garden soil will give good returns.

We have always depended on the South for plants, but this year we offer Oregon grown plants for seasonable delivery, per doz, 50 c; $100, \$ 3.00$ postpaid.

\section{Formaldehyde Treatment.}

Soak the tubers before cutting for one hour and $a$ half in a solution of $1 \mathrm{lb}$. (or pint) of Formaldehyde to 30 gallons of water. Formaldehyde is safe to use and is very effective for Scab. Pt. $60 \mathrm{c}$.

\section{PEANUTS}

CUITURz. Select warm light or sandy soil rich in lime; if not rich in lime, the soil must be made so by using air slaked lime or land plaster. Rather uncertain in this locality, but we have seen some splendid results in favored spots. Pkg., $15 \mathrm{c}$

\section{PARSLEY}

One ounce to 150 feet of drill. Sow in drills one foot apart, in rich, mellow soil; soak the seed 12 hours before sowing, which should be done in early spring, as they are very slow to germinate. When one or two inches high thin out the plants to six inches apart in the rows. Used as a garnish for table, also in soups.

\section{CHAMPION MOSS CURLED (65 days).}

A compact growing finely cut and beautifully curled variety. Pkt., 5c; oz., $20 \mathrm{c}$; $1 / 4 \mathrm{lb}$., $35 \mathrm{c}$; lb., $\$ 1.50$.

\section{HAMBURG (100 days).}

(Turnip rooted). The root is the edible portion and is extensively used for flavoring soups, etc. Pkt., $10 \mathrm{c}$; oz., $20 \mathrm{c}$; $1 / 4 \mathrm{lb}$., $50 \mathrm{c}$; lb., $\$ 1.50$.

\section{PLAIN (70 days).}

Leares flat, deeply cut but not curled; often preferred on account of the very dark color as well as the hardiness of the plant and its superiority for flavoring. Pkt., $10 \mathrm{c}$; oz., $20 \mathrm{c}$; $1 / 4 \mathrm{lb}$., $50 \mathrm{c}$.

\section{PUMPKINS}

CULTURE. Plant in good soil, when the ground has become warm, in hills eight to ten feet apart each way, or, as the general practice is with corn, in about every fourth hill. Three pounds per acre alone or about one pound with corn.

\section{PUMPKINS, CHEESE.}

The most popular for pies; large, flat round; creamy yellow skin: thick, orange flesh of fine quality; a splendid keeper. Pkt., כ̄c; oz., 20c; 1/4 lb., $50 \mathrm{c}$.

\section{CONNECTICUT FIELD.}

A productive, large orange colored field Pumpkin. usually grown for stock feeding, but it also makes good pies. Pkt., $5 \mathrm{c}$; oz., $20 \mathrm{c}$; $1 / 4 \mathrm{lb}$., $50 \mathrm{c}$.

POT IRON OR KING OF THE MAMMOTHS.

This strain produces the biggest Pumpkins grown, sometimes measuring 6 feet in circumference and weighing 200 to 250 pounds; outside color, deep orange yellow; flesh very thick, fine grained, tender, of bright yellow color, and of excellent quality for pies and other uses. Pkt., 5c; oz., $20 \mathrm{c} ; 1 / 4$ lb., $50 \mathrm{c}$

\section{WINTER LUXURY.}

A superior pie Pumpkin, small, but enormously productive and an excellent keeper; shape slightly oval, about 10 inches in diameter; color, golden russet, finely netted; flesh deep golden, sweet and tender. Pkt., 5c; oz., 20c; $1 / 4$ lb., $50 \mathrm{c}$.

\section{SUGAR}

A handsome and productive small Pumpkin, 10 to 12 inches in diameter: almost round, with orange skin; flesh deep yellow; fine grained and very sweet. Pkt., 5c; oz., 20c; $1 / 4$ lb., 50c.

\section{BIG TOM}

A fine-grained, oval-shaped Pumpkin of rich flavor. Skin and flesh are cream color and it keeps well if stored in a dry place. Pkt., jc; oz., $20 \mathrm{c} ; 1 / 4 \mathrm{lb} ., 50 \mathrm{c}$

\section{Use potato fertilizer on your potato patch, it will nearly double your yield. It's not an expense, it's an investment.}




\section{RADISH SEED: Culture}

One ounce will sow 100 feet of drill.

For early use select only forcing varieties and sow in hotbeds or under glass any time from January until March. Begin sowing outdoors as soon as the soil is in working condition, selecting, if posslble, a light, sandy loam. Although seed of the monthly radishes may be sown broadcast, the summer and winter sorts should be sown in drills twelve to eighteen inches apart, but not before May 15th, as earlier sowings will most likely run to seed. For winter sow from July 15th to August 15th in drills eighteen inches apart, later thinning out to six inches apart.

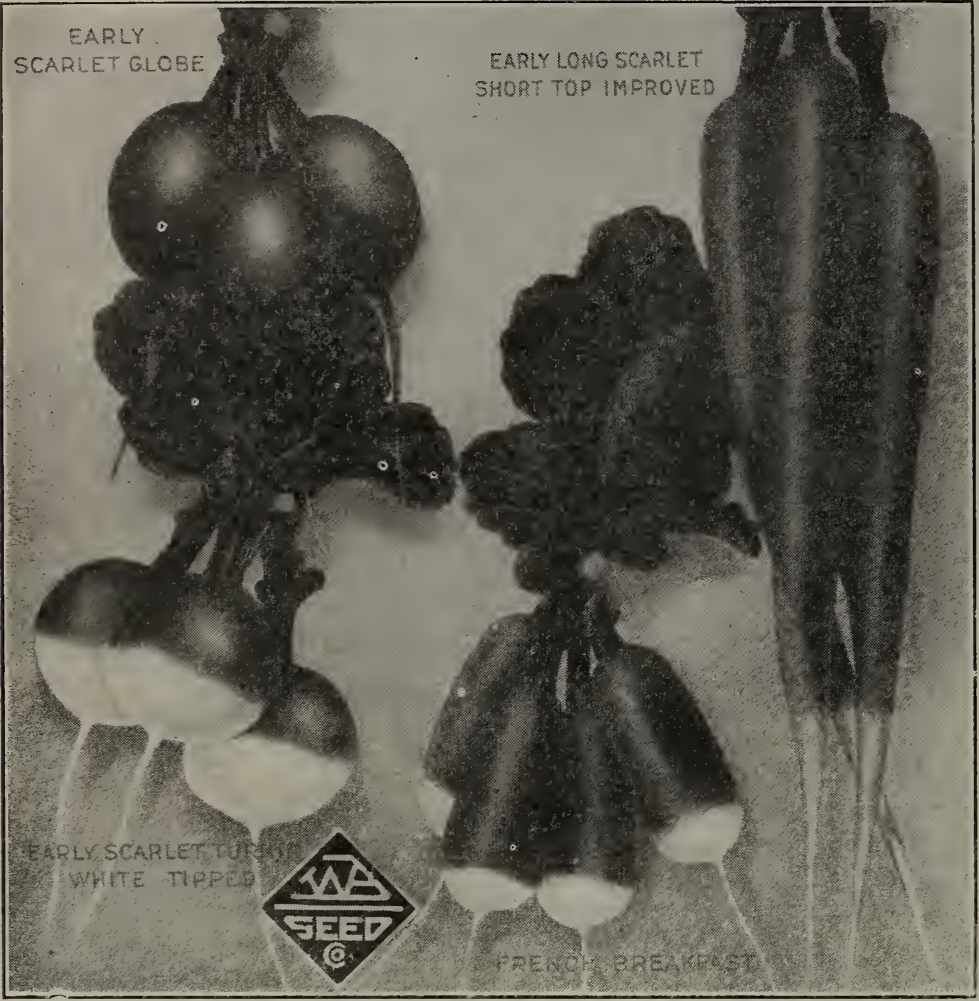

This illustration shows four prime favorites Early Scarlet Globe or (Forcing), Long Scarlet Short Top, Early Scarlet Turnip, white tipped, and French Breakfast.

We can heartily recommend any of these four varieties. Pkg. each 4 varieties $20 \mathrm{c}$.

\section{EARLY SCARLET TURNIP}

One of the standard sorts for general sowing. Roots are turnip shaped, dark red and of fine quality. Per pkt., 5c; oz., $20 \mathrm{c} ; 1 / 4$ lb., $35 \mathrm{c} ; 1 \mathrm{~b} ., \$ 1.00$.

\section{EARLY WHITE TURNIP}

Preferred by many to the red sorts. Flesh clear white, tender and sweet. Per pkt., 5c; oz., $20 \mathrm{c} ; 1 / 4 \mathrm{lb}$., $35 \mathrm{c}$; 1b., $\$ 1.00$.

\section{CRIMSON GIANT}

A forcing variety of unusual size, but better adapted to outdoor culture. It is solid, crisp and tender. Pkt., 5c; oz., $20 \mathrm{c}$; $1 / 4$ lb., $35 \mathrm{c}$; lb., $\$ 1.00$.

\section{CHARTIER}

Roots are red with a white top, slender, and remain solid and crisp until of large size. Per pkt., 5;c oz., 20c; 1/4 lb., 35c; 1 lb., $\$ 1.00$.

\section{ICICLE}

One of the earliest and purest of all long, white varieties. For crispness and tenderness it is un surpassed. P'er pkt., 5c; oz., $20 \mathrm{c} ; 1 / 4$ lb., $35 \mathrm{c} ; 1$ lb., $\$ 1.00$

\section{LONG WHITE VIENNA}

The skin and flesh are both pure white and of excellent quality. Per pkt., 5c; oz., $20 \mathrm{c} 1 / 4 \mathrm{lb}$., $35 \mathrm{c} ; 1 \mathrm{~b} ., \$ 1.00$.

\section{LONG SCARLET SHORT TOP}

A long, smooth, tapering radish somewhat smaller but brighter in color than Chartier. Per pkt., $5 \mathrm{c}$; oz., $20 \mathrm{c}$; $1 / 4$ lb., $35 \mathrm{c}$; 1b., $\$ 1.00$.

\section{ROSE CHINA WINTER}

(Scarlet China). A rose colored variety of fine quality; flesh white. Per pkt., $5 \mathrm{c}$; oz. $20 \mathrm{c}$; $1 / 4$ lb., $35 \mathrm{c}$; lb., $\$ 1.00$.

\section{ROUND BLACK SPANISH}

Pkt., 5c; oz,. 20c; 1/4 1b., 35c; lb., $\$ 1.00$.

\section{SCARLET GLOBE FORCING}

Popular everywhere, either for forcing or outside sowing. Its brilliant color, uniform shape, and crisp white flesh makes it a favorite with all. Per pkt., 5c; oz., $20 \mathrm{c}$; $1 / 4$ lb., $35 \mathrm{c}$; lb., $\$ 1.00$.

\section{MAMMOTH SANDWICH ISLAND}

The roots are white, extra long, straight and very tender. Per pkt., $5 \mathrm{c}$; oz., $20 \mathrm{c} ; 1 / 1 \mathrm{lb} ., 35 \mathrm{c} ; 1 \mathrm{~b}$. $\$ 1.00$.

\section{FRENCH BREAKFAST}

This well known radish is olive shaped, brigbt scarlet with the exception of the white tip. Por pkt., $5 \mathrm{c}$; oz., $20 \mathrm{c}$; $1 / 4 \mathrm{lb}$., $35 \mathrm{c}$; lb., $\$ 1.00$

\section{EARLY SCARLET TURNIP-WHITE TIPPED}

An exceptionally fine strain grown largely by market gardeners. Its color is of the deepest scarlet with a prominent white tip; superb flavor. Per pkt., 5c; oz., $20 \mathrm{c} ; 1 / 4$ lb., 35c; lb., $\$ 1.00$.

\section{HALF-LONG BLACK}

Highly recommended as the best sort for winter In color it is more of a gray than black and grows to an extremely large size. Per pkt., 10c; oz., $20 \mathrm{c} ; 1 / \mathrm{t}$ lb., $35 \mathrm{c}$; lb., $\$ 1.00$. 


A sack of fertilizer will produce a
surplus to sell your neighbor

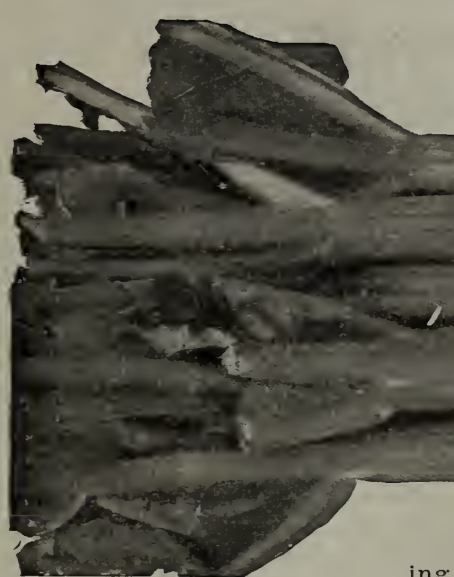

\section{RHUBARB}

Later thin out the seedlings to four inches apart and in the fall transplant to permanent beds of well enriched soil, setting plants not less than three feet apart. They will be in condition for use the following year. Per pkt., $10 \mathrm{c}$; 0z., $25 \mathrm{c}$. Rhubarb Roots, Nuch the Better Way to Plant. Large crown, 35c each; seedlings, $10 \mathrm{c}$ each.

\section{RUTABAGA}

See Turnips.

\section{SALSIFY OR}

\section{VEGETABLE OYSTER}

CUITURE. Also known as Oyster Plant or Vegetable Oyster. Treat about the same as carrot, except that salsify is hardier, and may be left in the ground all winter. Sow in drills a convenient distance, 1 to 2 feet apart, and thin to 4 inches in the row. Cover seed about 1 inch. Use 1 ounce to 75 feet of row; 8 to 10 pounds per acre. Sow in April or May.

\section{MAMMOTH SANDWICH ISLAND.}

This is an improved type and the largest and most profitable salsify now in cultivation. It is white in color: being quite smooth is a satisfactory sort in every way. It is invaluable to market gardners. Pkt., 5c; oz., $35 \mathrm{c}$; 1/4 lb., $\$ 1.00$.

\section{SPINACH}

CUITURE. One ounce will sow 50 feet of drill. First sowing should be made as soon as the ground is open in spring. Sow seeds half inch deep in drills one foot apart and every two weeks thereafter for succession. Sowings made during September usually grow large enough to winter over and with little protection afford Spinach very early in the following spring. A rich soil is essential to obtain best results.

\section{BLOOMSDALE, SAVOY-LEAVED}

The popular fall Spinach so largely grown for market. Grows upright, the leaves being crumpled, dark green and very thick. Per pkg., $5 \mathrm{c}$; oz., $20 \mathrm{c}$; $1 / 4$ lb., $35 \mathrm{c}$; 1b., $\$ 1.00$.

\section{EARLY GIANT, THICK-LEAVED}

A quick growing sort and one of the best for wintering over. It is of large size, rich green color and excellent quality. Pkg., 5c; oz., 20c; $1 / 41 \mathrm{~b} ., 35 \mathrm{c}$; 1b., $\$ 1.00$.
PRICKLY WINTER. LONG-STANDING PRICKLY.

Matures a little later than the round-leaver sorts, but furnishes a large quantity of thick leaves of excellent flavor. Pkt., כ̄c; oz., 20c; 1/t lb., $35 \mathrm{c}$; lb., $\$ 1.00$; postpaid.

\section{SWISS CHARD}

SEE BEETS.

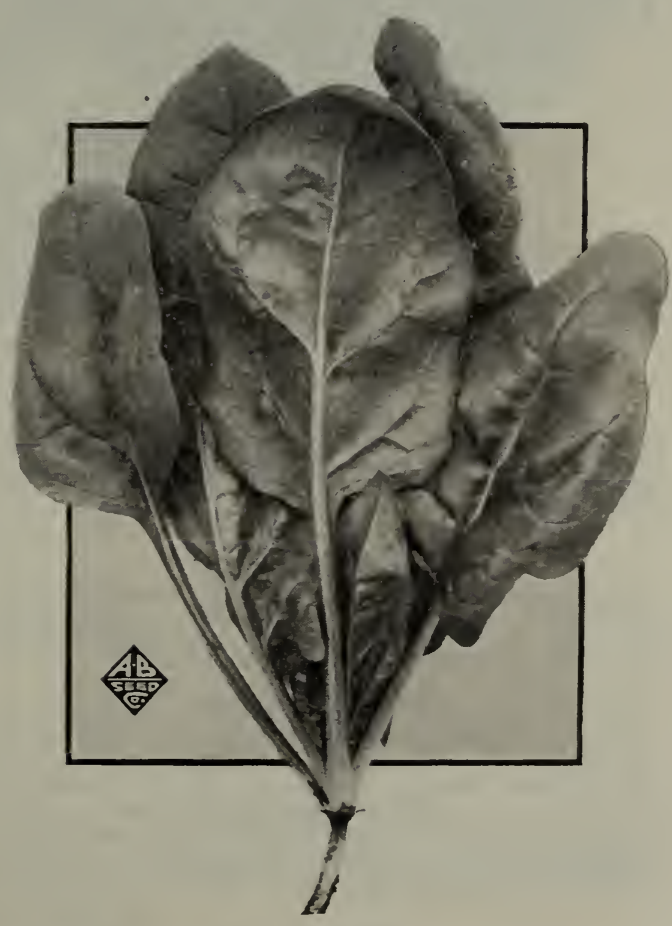

Remember that we pay postage on all seeds except where noted. Others are sent at your expense. 
These varieties have found favor wherever tried

\section{SQUASH}

\section{SUIMIMER VARIETIES}

\section{GOLDEN SUMMER CROOKNECK.}

Plants of true bush growth, very early fruiting and productive. The squashes are of the popular crooked-neck type, rich golden yellow, thickly warted. Pkt., 5c; oz., $20 \mathrm{c}$; $1 / 4$ lb., $35 \mathrm{c}$; postpaid.

\section{EARLY WHITE}

A well-known variety of dwarf habit and upright growth. Surface comparatively smooth; color creamy white. Pkt., 5c; oz., $20 \mathrm{c}$; $1 / 4$ lb., $35 \mathrm{c}$.

\section{EARLY YELLOW}

very early, fiat, scalloped variety of largest size; skin deep yellow; the flesh is pale yellow and well flavored. Pkt $5 \mathrm{c}$; oz., $20 \mathrm{c}$; $1 / 4 \mathrm{lb}$., $35 \mathrm{c}$.

\section{ITALIAN VEGETABLE MARROW}

A variety producing large oblong fruits, dark green at first, but as they mature becoming marbled with yellow and lighter green in stripes. Pkt., $5 \mathrm{c}$; oz., $20 \mathrm{c}$; $1 / 4$ lb., $35 \mathrm{c}$.

\section{WINTER VARIETIES}

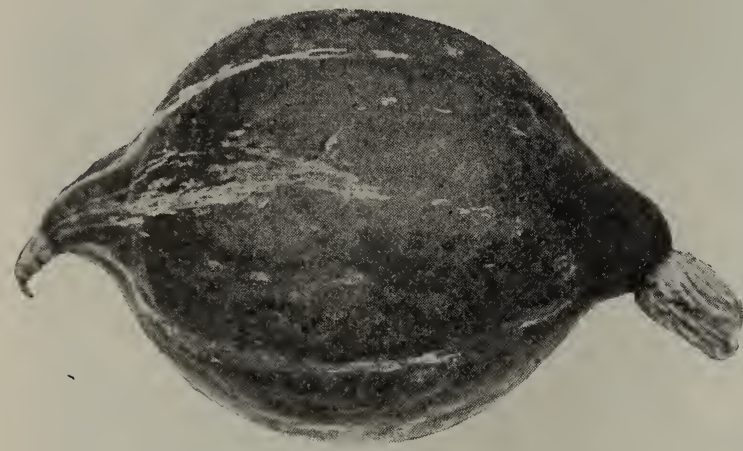

TRUE HUBBARD

The best seller and most popular variety on our list. Rind dark green, warty and very hard. Flesh light orange, very dry, sweet and rich flavored. Has no superior. Keeps perfectly through the winter. Pkt., $10 \mathrm{c}$; oz., 20c; $1 / 4$ 1b., $50 \mathrm{c}$.

\section{RED OR GOLDEN HUBBARD.}

The heavily warted skin is of a rich orangeyellow, turning to deep salmon-red when ripened. it is equally as productive and fine in quality as the orioinal Hubbard Squash. Plkt., 5c; oz., 20c; $1 / 4$ lb., $50 \mathrm{c}$.

\section{BOSTON MARROW}

A fall and winter variety of large size, oval form, skin thin; when ripe, bright orange; excellent flavor. We have a very fine stock of this sort. Pkt., 5c; oz., 20c; $1 / 4$ lb., $35 \mathrm{c}$.

\section{NEW DELICIOUS}

This new fall and winter squash resembles the old Hubbard; average weight is between five and ten pounds. Seed cavity small; flesh exceedingly thick, compact, fine grained; color, golden orange. The flesh is meaty, granulated, tender and almost of mealy dryness, cooking sweet and rich, whether steamed, baked, boiled or made into pies. Pkt., $5 \mathrm{c}$; oz., $20 \mathrm{c} ; 1 / 4$ 1b., $50 \mathrm{c}$.

\section{DELICATA.}

A small-fruited variety suitable for both summer and winter use; oblong, slightly ribbed, with orangeyellow skin striped with green. Pkt., $5 \mathrm{c}$; oz., $20 \mathrm{c} ; 1 / 4 \mathrm{lb}$., $50 \mathrm{c}$.

\section{TURNIPS \\ EARLY VARIETIES \\ EARLY WHITE FLAT DUTCH}

(Strap-Leaver). An old stand-by, and one of the most popular early varieties for either spring or fall plantings. Of medium size and a quick grower. Flesh and slin pure white; fine grained and sweet. Plkt., 5c; oz., 20c; $1 / 4$ lb., 35c.

\section{EXTRA EARLY WHITE EGG}

In our Extra Early White Egg you will have a turnip of the sweetest flavor ready for use in six weeks from the time of sowing with good season. In quality it is the finest of all. Very attractive when bunched for market. Plkt., 5c; oz., $20 \mathrm{c} ; 1 / 4 \mathrm{lb} ., 35 \mathrm{c}$

\section{WHITE GLOBE}

Color pure white; shape round; size large; solid, quick in growth for a large turnip, producing a great weight to the acre. Pkt., $5 \mathrm{c} ; 0 \mathrm{z} ., 20 \mathrm{c} ; 1 / 4$ lb., $35 \mathrm{c}$

\section{EXTRA EARLY WHITE MILAN}

A very early variety, medium sized, flat and clear white. A fine home-garden variety. Pkt., $5 \mathrm{c}$; oz., 30c; $1 / 4$ lb., $\$ 1.00$.

\section{EXTRA EARLY PURPLE TOP MILAN}

The earliest turnip in cultivation and a splendid variety: bulb white, flat of medium size, with a bright purple top; one of the sweetest and finest flavored of summer sorts. Plkt., 5c; oz., $30 \mathrm{c} ; 1 / 4 \mathrm{lb}, \$ 1.00$

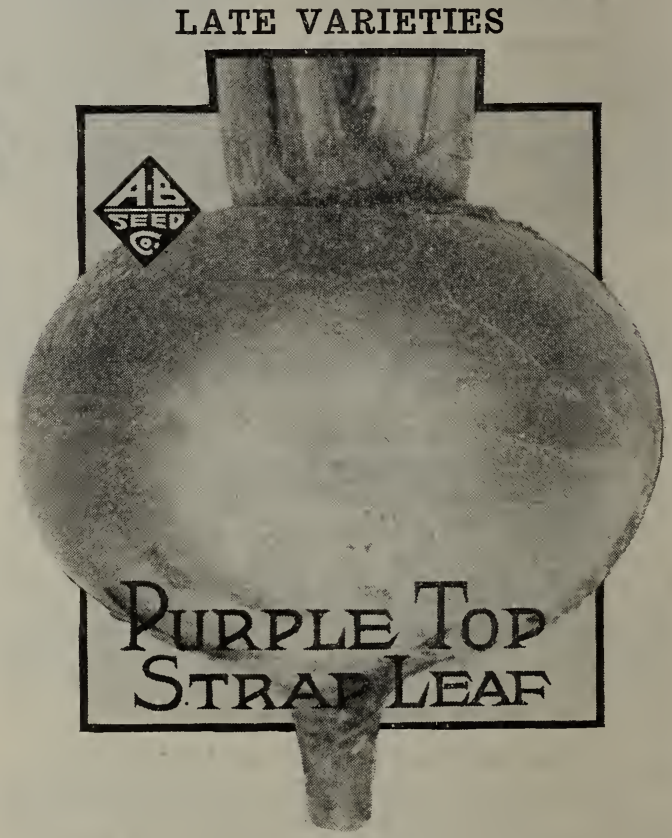

\section{PURPLE TOP, STRAP LEAF}

Used largely for sowing broadcast among corn and potatoes. It is round and flat, white on the bottom and a reddish purple above grouna, and a very quick grower. It is esteemed as a fine toble variety. Pkt., $5 \mathrm{c}$; oz., $20 \mathrm{c} ; 1 / 4 \mathrm{lb} ., 35 \mathrm{c}$.

\section{PURPLE TOP WHITE GLOBE}

A large globe-shaped variety; purple above ground; it is handsome and of excellent quality and-recommended: both for the family garden and field crop. Pkt., 5c; oz., $20 \mathrm{c}$; $1 / 4$ lb., $35 \mathrm{c}$; lb., $\$ 1.00$. 
Was your garden satisfactory last year? Plant tested seeds

\section{TURNIPS - Contd.}

\section{YELLOW VARIETIES.}

Yellow Aberdeen. Pkt., 5c; oz., 20c; I/4 lb., $35 \mathrm{c} ; 1 \mathrm{~b} ., \$ 1.00$.

Yellow Globe. Pkt., 5c; oz., 20c; $1 / 4$ lb., 35c; lb., \$1.00.

Improved Golden Ball. Pkt., 5c; oz., 20c; 1/4 lb., $35 \mathrm{c}$; 1b., $\$ 1.00$.

Danish Bordfeldel. Pkt., 5c; oz., 20c., $1 / 4 \mathrm{lb}$. 35c: $1 b . . \$ 1.00$.

\section{RUTABAGAS}

IMPROVED AMERICAN PURPLE TOP.

This strain is of American origin, bred to a smaller top and short neck. The bulbs are of great size, yellow-fleshed and purple crown; one of the most desirable varieties now cultivated. Pkt., 5c; oz., 20c; 1/4 lb., 35c; 1 lb., $\$ 1.00$

\section{BANGHOLM RUTABAGA.}

Oblong, globular shaped, with small neck, yellow flesh, very dark purple top. Superior to all other Swedes. Has been awarded first-class certificate by the Danish government as the best cropping rutabaga. Pkt., $5 \mathrm{c} ; 0 \mathrm{z} ., 20 \mathrm{c} ; 1 / 41 \mathrm{~b} ., 35 \mathrm{c}$; $1 \mathrm{lb} ., \$ 1.00$.

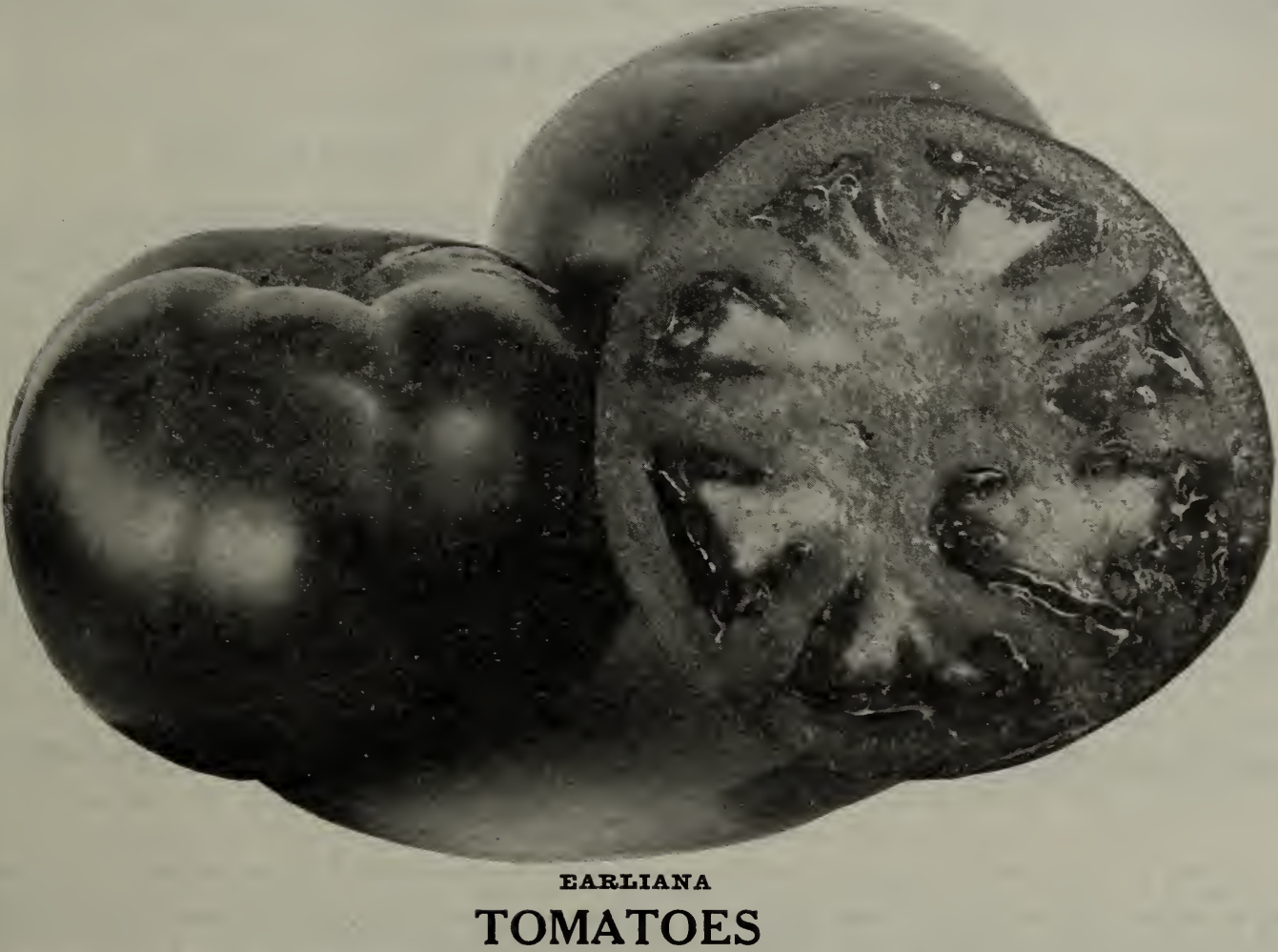

SPARKS' EARLIANA

The tomatoes are bright red and grow close together in clusters; all of medium size, averaging $2 \frac{1}{2}$ inches in diameter. They are smooth and solid, quite thick through and free from rough ribs or cracks. The flesh is a deep red, with solid center and small cells; slightly acid flavor. Best for this vicinity. Pkt., $10 \mathrm{c}$; oz., $30 \mathrm{c}$.

\section{COMET}

The very best forcing variety and a general favorite with greenhouse growers. Color is a beautiful scarlet; fruits are of good size, very smooth and uniform. We offer a select strain from inside stock. Pkt., 10c; oz., $30 \mathrm{c}$.

\section{CHALK'S EARLY JEWEL}

One of the best early scarlet varieties. The fruit is uniform, solid and of fine quality. Pkt., $10 \mathrm{c}$; oz., $30 \mathrm{c}$.

\section{DWARF CHAMPION}

Of dwarf, stiff, upright growth, scarcely needIng support; early and prolific, fruits of reddish purple color. Pkt., 10c: oz., $30 \mathrm{c}$.
JOHN BAER.

Large, smooth, blood-red sort; early; ripens all over and through at once. Will bear shipping long distances. Very few seeds and has no hard, green core. Pkt., 10c; oz., 30c.

\section{RED CHERRY.}

Little fruits of a bright scarlet color. Pkt. $10 \mathrm{c} ; \mathrm{oz}$., $30 \mathrm{c}$.

\section{YELLOW PEAR SHAPED.}

A small-fruited variety, which is golden-yellow. It is very useful for salads, when the fruit is simply cut in two lengthwise. Pkt., 10c; oz., $30 \mathrm{c}$.

\section{TOBACCO}

Sow early in frames or seed bed and transplant when weather has become warm and danger from frost passed.

Connecticut Ieaf. Pkt., 10c.

Iavana. Pkt., $10 \mathrm{c}$

Tobacco plants, $10 \mathrm{c}$ each. Pot grown; ready to put out. Ready May 1 st. 


\title{
VEGETABLE PLANTS AND ROOTS
}

\author{
We grow large quantities vegetable plants and roots and can supply the varieties listed below \\ In their proper season. They grow under the best condition to make them hardy and $\nabla$ igorous \\ and we give expecial attention to packing and shipping. \\ They may be sent by mail, and we guarantee that they will arrive in good condition.
}

\section{ASPARAGUS CULTIVATION}

See that the ground is well drained, work it up fine and deep and make it very rich with fertillzer or barnyard manure. Place the plants eight inches apart in rows three feet apart. Spread out the roots in a trench made deep enough to permit their crowns to be covered with three or four Inches of mellow earth. Give the bed liberal dressings of fertilizer at intervals, and, except near the sets, three pounds of salt per square yard early every spring. Do not cut for use until the plants bave grown two seasons.

\section{ASPARAGUS PLANTS}

Palmetto Two-year-old Plants, postpaid, 50c per dozen; $\$ 3.00$ per 100

\section{CABBAGE PLANTS}

Set out in open ground as soon in spring as the land can be properly prepared. A rich, warm, flbrous loam is best. Have the plants in the rows 20 to 24 inches apart, and rows at least 2 feet apart. Give thorough cultivation, and irrigate in dry weather if practicable. Protect against the ravages of cutworm, maggot and green worm. A little nitrate of soda applied around the plant is of great benefit. Potash applications, such as wood ashes or muriate, may also do much good. For late Cabbage plants transplant in June and July, giving the plants more room than allowed for earliest C'abbages. Dusting with tobacco dust, insect powder, etc., or splashing with hot soapsuds, especlally Whale-Oil Soap solution, are good and safe remedies for some of the insect pests attacking plants of the Cabbage.

We carry both the early and late varieties in season. Dozen, 25c; $100, \$ 1.50$, postpaid. We are prepared to make special prices on quantities over 1,000 10 10,000 .

By freight or express, $100 \$ 1.00 ; 1,000, \$ 6.00$.

\section{CAULIFLOWER PLANTS}

Set in open ground as soon in spring as the land can be put in good order. Soil to be a warm, very rich, fibrous loam, well supplied with humus and moisture. Copious water applications during dry weather, especially when the plants are heading, and light dressings of nitrate of soda and potash are of much help. Set plants 2 to $2 \frac{1}{2}$ feet apart each way. When heads are formed and are hard, they should be blanched by drawing the leaves together and tying with raffia, or strips of noft cloth.

Doz., 30c; $100, \$ 2.00$, postpaid. Doz., $20 \mathrm{c} ; 100, \$ 1.50,1,000, \$ 12.00$, express or freight. We are prepared to make special prices on quantities over 1,000 to 10,000 .

It has been demonstrated that CARCo will save at least $50 \%$ of your cabbage, kale or cauliflower plants. Will also save your onions, turnips and rutabagas.

\section{CELERY PLANTS}

In May to June, set the plants in very rich and well-prepared land, 6 inches apart in the rows, and rows 3 to 4 feet apart. Give thorough and clean cultivation, and blanch by means of boards ret up against the rows. For later and winter Celery the rows in which the plants are set should be 4 to 5 feet apart. Blanch by earthing up gradually clear to within a few inches of tip of leaves. For winter storage, take up the plants with roots, and place upright on wet soil in a dark cellar or root-house, packing closely.

Leading varieties, dozen, $25 \mathrm{c} ; 100, \$ 1.50$ post paid.

\section{CHIVES:}

Chives are a small hardy perennial plant, resembling the onion leaves in appearance. They are grown for the young leaves which are produced freely early in the spring and give a mild onion havor to sausages, salads and various dishes. The tops can be shorn off close to the ground as needed. They can be grown also in pots in a sunny window during winter. Bunch, 20c, by mail, postpaid.

\section{HORSE-RADISH SETS}

Horse-radish is always in demand in winter and spring. The culture is by sets or root cuttings, as it seldom seeds. These sets are planted in rows or furrows 2 to 3 feet apart and 15 to 18 inches apart in the rows. The sets should be placed in a perpendicular position, with crown 3 to 6 inches below surface. Horse-radish delights in a deep, rich soil. It makes large top growth, giving weeds small chance. Doz., $60 \mathrm{c} ; 100 \$ 2.50$ and $\$ 3.00$, postpaid.

\section{PEPPER PLANTS}

Set in open ground in warm, very rich and well-prepared soil, making the rows 2 to 3 feet apart, with plants 15 to 18 inches apart in the rows. This variety has become very popular and always in large demand.

IARGI BRII. Doz., $\$ 1.25$, postpaid.

Page 32 


Send in your order early
We're bound to be rushed later

\title{
VEGETABLE PLANTS AND ROOTS—Contd
}

\author{
RHUBARB ROOTS
}

This splendid old time plant, which seems to be the Missing Link between fruits and vegetablea and which did such valiant service in the early days as a pie-fller, is again coming into a welldeserved popularity, because of the many new uses that have been found for it.

Its fine medicinal properties make it most wholesome, and it is not only welcomed by the houso Wfe in the early spring, but is now used in combination with other fruits, such as pineapple, figs, - tc., to make the most delicious jams and preserves and also a great variety of puddings and desserta

This, of course, gives it a ready sale at good prices and makes it one of the best staples of the market gardener. Our roots are strong, healthy and vigorous and the varieties we quote are the most desirable and the best for this locality.

\section{RHUBARB}

\section{VICTORIA MAMIMOTH}

Best for home use and to market; $20 \mathrm{c}$ each. Doz. $\$ 2.00$. Large Clump each $35 \mathrm{c}$ to $50 \mathrm{c}$

\section{TOMATO PLANTS}

Our TOMATO PIANTS listed under this head are strong, sturdy plants which will stand shipping and transplanting and give excellent satisfaction. It is the EARIY TOMATO that brings the HIGH PRICES and you save much time and trouble by buying our plants, as it is hard to get a jood early start for tomatoes without hot-house advantages.

They may be shipped by mail and we guarantee good delivery.

For early varieties set plants 4 feet apart each way in warm, mellow soil of fair fertility as soon as danger from belated frost is past. For main crop, plant in fairly warm soil, 5 feet apart each way. A very ornamental show can be made in

\begin{abstract}
the home garden by training tomato plants to stakes, poles or trellis. Applications of superphosphate, or of some good complete (vegetable) fertilizer often have a very happy effect on Tomatoes in hastening maturity and increasing the yield.

Sparks Earliana, Dwarf Champion, transplanted into flats Doz. $35 \mathrm{c}, 100, \$ 2.25$, postpaid. 1,000 , $\$ 17.50$, by freight or express Pot grown, doz. $\$ 2.30$, postpaid
\end{abstract}

\section{SAGE}

(Salvia officinalis). The most extensively used of all herbs for seasoning and dressing; indispensable. Two-year-old plants, each, 35c;

\section{KALE-DWARF SCOTCH}

Doz., 25c; 100, $\$ 1.50$, postpaid.

\section{THOUSAND HEADED}

Doz., 25c; 100 , $\$ 1.50$, postpaid.

GOOD SEEDS are essential, to obtain best results the soil must contain available food needed for plant growth. After seeds germinate exhausting the supply of food contained in the seed itself the soil must yield proportionate supplies of $\mathrm{Ni}$ trogen, Phosphorus and Potash.

NITROGEN -increases growth and defers maturity so if plants grow luxuriantly without producing the desired flower, fruit or vegetable it is a sure sign that nitrogen is available in greater quantities than needed.

PHOSPHORUS-hastens the maturity of crops, it has a ripening effect and seems to hasten grain and fruit formation. It stimulates root development in young plants. It helps to transfer substances from the stalks, leaves and other growing parts to the seed.

POTASH -effects maturity, causes a longer growing period, holds back maturity of grain crops but acts in just the opposite way with root crops in fact the maturity of root crops is hastened by a supply of Potash.

Potash is also a check to insect pests and plant diseases, it is distasteful to some insects, also makes plants better able to resist attacks of certain fungi by producing a stronger and more vigorous growth.

\section{SUPERIOR FERTILIZERS GIVE RESULTS}




\section{Garden Calendar}

\begin{tabular}{|c|c|c|c|c|}
\hline $\begin{array}{l}\text { Quantity Seed } \\
\text { Required for } \\
\text { 100-ft. Row }\end{array}$ & $\begin{array}{l}\text { Ruantity Seed } \\
\text { Required for } \\
1 \text { Acre }\end{array}$ & $\begin{array}{l}\text { General Time } \\
\text { of Sowing } \\
\text { Puget Sound }\end{array}$ & $\begin{array}{c}\text { Crop } \\
\text { Matures }\end{array}$ & $\begin{array}{l}\text { Depth } \\
\text { to Plant } \\
\text { in inches }\end{array}$ \\
\hline Asparagus Plants ..................100 & 7260 & Oct. to April & Following Spring & 3 to 5 \\
\hline Beans, Dwarf, Drill.................2 lbs. & $60 \mathrm{lbs}$. & April to July & 45 to 65 days & 1 \\
\hline Beans, Pole, 100 hills................ lb. & $30 \mathrm{lbs}$. & April to July & 75 days & $1 \frac{1}{2}$ \\
\hline Beets Table $\ldots \ldots \ldots \ldots \ldots \ldots \ldots \ldots \ldots \ldots 4$ oz. & 6 to $7 \mathrm{lbs}$. & March to October & 65 days & $\frac{3}{6}$ \\
\hline Beets, Mangels................... oz. & 5 lbs. & April to July & 75 days & i \\
\hline Cabbage, 1 oz., 2000 Plants. . . . . . . . . .50 & 10000 & March to August & 100 days & 3 \\
\hline Celery, 1 oz., 4000 Plants..............100 & & March to July & 120 days & 2 \\
\hline Carrots $\ldots \ldots \ldots \ldots \ldots \ldots \ldots \ldots \ldots \ldots \ldots \ldots \ldots \ldots \ldots$ & $2 \frac{1}{2} \mathrm{lbs}$. & March to July & 60 days & $\frac{1}{2}$ \\
\hline Corn, Sweet.................... & $15 \mathrm{lbs}$. & April to June & 100 days & $1 \frac{1}{2}$ \\
\hline Cucumbers..................... & 3 lbs. & April to June & 120 days & 1 \\
\hline Endive........................ & 4 lbs. & July to October & 100 days & $\frac{1}{2}$ \\
\hline Horse Radish Roots.....................100 & & Spring & Fall & 4 \\
\hline Kale .................... & 2 lbs. & Feb. to August & 45 days & $\frac{1}{2}$ \\
\hline Kohl Rabi...................... oz. & 4 lbs. & Feb. to May & 4 Months & $\frac{1}{2}$ \\
\hline Leek. ...................... & 4 lbs. & Feb. to June & 3 Months & $\frac{1}{2}$ \\
\hline Lettuce, Leaf. ................... & 4 lbs. & All Year & 60 days & $\frac{3}{6}$ \\
\hline Lettuce, Head. . . . . . . . . . . . . . . . . . & 4 lbs. & All Year & 60 days & $\frac{1}{t}$ \\
\hline Melons, Musk. ................... & 3 lbs. & May & 120 days & $\frac{1}{3}$ \\
\hline 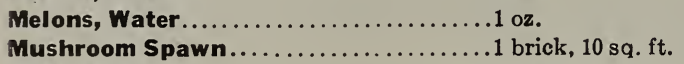 & 3 lbs. & May & 120 days & 1 \\
\hline 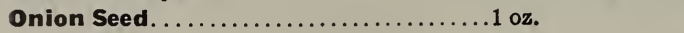 & 4 lbs. & All Year & 100 days & $\frac{1}{2}$ \\
\hline Onion Sets......................... & & All Year & 45 days & $1,0 \mathrm{x}$. \\
\hline Parsley $\ldots \ldots \ldots \ldots \ldots \ldots \ldots \ldots \ldots \ldots \ldots \ldots$ oz. & 3 lbs. & April to July & 60 days & $\frac{1}{6}$ \\
\hline Parsnips.$\ldots \ldots \ldots \ldots \ldots \ldots \ldots \ldots \ldots \ldots \ldots \ldots$ oz. & $3 \mathrm{lbs}$ & April to June & 100 days & $\frac{1}{6}$ \\
\hline Peas, Garden.......................... & 100 to $150 \mathrm{lbs}$ & August to June & 60 days & 1 \\
\hline Potatoes................... & 400 to $600 \mathrm{lbs}$ & Feb. to June & 120 days & 3 to 6 \\
\hline Pumpkin...................... & 4 lbs. & April to July & 125 days & 1 \\
\hline Radish. ................. & $-10 \mathrm{lbs}$ & August to June & 30 to 60 days & $\frac{1}{2}$ \\
\hline Rutabaga................... & 2 lbs. & March to October & 60 days & $\frac{1}{3}$ \\
\hline Turnip $\ldots \ldots \ldots \ldots \ldots \ldots \ldots \ldots \ldots \ldots \ldots$ oz. & 2 lbs. & March to October & 60 days & 1 \\
\hline Tomato Plants ......................40 & & April & 120 days & 2 \\
\hline
\end{tabular}

\section{FIELD SEEDS}

Lbs. per Acre Lbs. per Bu.

Alfalfa 10 to 20

Alsyke Clover................ 6 to 10

Barley.................... 100

Beets, Mangels.............. 6

Buckwheat................... 40 to 60

Clover, Red.................. 8 to 15

Clover, Alsyke................. 6 to 10

Clover, Crimson............... 10 to 15

Clover, Sweet................. 20 to 30

Clover, White; Pasture........ 8 to 10

Clover, White; Lawn........... 80 to 100

Corn, Field................... 12 to 20

Corn, Ensilage and Fodder..... 50 to 75

\section{GRASSES}

\begin{tabular}{|c|c|}
\hline Timothy......................... & 10 to 20 \\
\hline Orchard.................. & 40 to 60 \\
\hline Red Top, Hulled............... & 10 to 15 \\
\hline Red Top, Unhulled............ & 30 to 40 \\
\hline Rye Grass..................... & 30 to 50 \\
\hline Pasture...$\ldots \ldots \ldots \ldots \ldots \ldots$ & 30 \\
\hline Hay Mixture..$\ldots \ldots \ldots \ldots \ldots \ldots$ & 30 \\
\hline Kentucky Blue Pasture........ & 20 to 30 \\
\hline $\begin{array}{l}\text { Kentucky Blue, Lawn.......... } \\
\text { Sudan Grass. }\end{array}$ & $\begin{array}{r}150 \\
20\end{array}$ \\
\hline
\end{tabular}

Lbs. per Acre Lbs. per Bu.

Kale Stock................ 2

Millet..................... $50 \quad 50$

Oats, Grain................ 75 to $100 \quad 32$

Oats, Hay................ 125

Oats with Vetch............. Oats, $40 \mathrm{lbs}$.

Vetch, $60 \mathrm{lbs}$

Peas, Field; Grain.............. 90 to 125

Peas with Oats, Hay.......... Peas, 60 lbs.

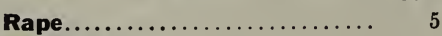

Rye, Grain .................... 120

Rye and Vetch, Cover Crop..... Rye, 40 lbs.

Vetch, 60 lbs.

Turnips and Rutagabas....... 2

Vetch, Seed................. 100

Vetch and Wheat............. Vetch, $60 \mathrm{lbs}$.

Vetch and Rye................ Vetch, $60 \mathrm{lbs}$

Rye, 40 lbs.

Vetch and Oats.............. Vetch, $60 \mathrm{lbs}$

Oats, 40 lbs.

Wheat, Grain .............. 120
Wheat and Vetch............ Wheat, $40 \mathrm{lbs}$.

Vetch, 60 lbs. 
A garden will save you money It's a pleasure to have one

\section{WOODRUEF BOYCE.}

\section{GRASS SEEDS}

\section{PER CENT PURE}

\section{RED CLOVER}

(Trifolium Pratense)
Do not trust to luck in buylng

seeds-Ours are tested seeds

We wish to impress upon the Western farmer the advantage in sowing this valuable crop, especially in such sections as are not favorable to the successful raising of alfalfa.

It is for most purposes as valuable as Alfalfa and is a more dependable crop in many localities west of the Cascades. It is equally good for hay, silage or forage and has no superior when plowed under as a nitrogen-giving fertilizer. When sowed under with Timothy it makes an especially satisfactory hay crop. It yields two crops of hay in a season and requires a rich, deep soil.

Since the value of this crop is greatly dependent on its frecdom from noxious weeds the purity of the seed used is of the greatest consequence and we do not hesitate to say that we have, absolutely the best Red Clover Seed on the market. It is $99 \%$ pure, that being a $7 \%$ higher test than is required by the Pure Seed Law and the highest human skill can attain, and is only made possible by the most painstaking effort and the most improved cleaning machinery.

The initial cost of this seed is but little more than the ordinary weed-mixed grade, and the difference in true marketable value is so great that there can be no comparison as to which it pays to sow.

WOODR UFF-BOYCE SUPFRIOR RED CIOVIR SFED, per lb., 65c; $10 \mathrm{lbs}$., $\$ 6.25 ; 100 \mathrm{lbs}$., $\$ 60.00$.

\section{WHITE CLOVER}

97 to $98 \%$ pure

Dwarf spreading variety, used especially for the making of fine lawns. None but the choice grade of seed should be used. The habits of white clover make it quite necessary that it be used in lawn seed. We have only the best grade and use no other in any seed we sell. Per 1b., 75c; 10 lbs., $\$ 5.50$.

\section{MAMIMOTH RED CLOVER}

This variety has a very rank growth and is not much used for hay or forage but makes an excellent green manure when plowed under. In habit it is similar to the Common Red Clover except that it lasts longer. Per 1b., $65 \mathrm{c} ; 10 \mathrm{lbs}$. $\$ 6.25$.

\section{CRIMSON CLOVER}

Crimson Clover is an annual, useful principally as a cover crop or to plow under for green manure. It is grown quite extensively in the south, but it is not specially recommended for the Northwest, as we have other crops which are better adapted to this locality. Twelve to twenty pounds of seed is somn to the acre. Per 1b., 35c; $10 \mathrm{lbs}$., $\$ 3.00$.

\section{ALSIKE CLOVER 98 PER CENT PURE}

\section{A Clover for Cold, Wet Land}

This variety is sometimes called Swedish Clover and is a perennial, 1 to 3 feet high, succeeding best in cold stiff soils, and in marshy lands which are too wet for other species. It grows well in the far north and in high altitudes and can withstand severe cold.

The blossoms are valuable in bee culture. Since it matures in the same length of time required for Timothy, they may be planted together with excellent results, and it is also good in pasture mixtures for wet land. When used alone, sow $15 \mathrm{lbs}$. to the acre.

OUR BEST AISIKE in less than 10-1b. lots, per $1 \mathrm{~b} ., 65 \mathrm{c} ; 10$ lbs., $\$ 6.25$.

\section{WHITE SWEET CLOVER OR BOKHARA}

The value of this clover is now being recognized not only for its use in bee culture but also for pasture, forage and hay. It has a prolific growth, sometimes attaining a height of five feet, and seed sown in the spring will produce a crop the following fall and two or three crops the following year. It is a biennial but readily reseeds itself. It is covered with small white flowers of great fragrance. Per lb., $40 \mathrm{c} ; 10$ lbs., $\$ 3.50$.

\section{GRIIMIV ALFALFA}

\section{GRIMM STRAIN}

We have been fortunate in obtaining a few hundred pounds of the original strain of this wonderful hardy Alfalfa which all the experimental stations recommend as being the nardiest of Alfalfas.

All farmers should endeavor to sow Alfalfa as it is by far the best paying hay crop one can grow. A few pounds of this seed will demonstrate whether or not it can be grown.

Per pound post paid, 75 cents.

\section{ALFALFA SEED}

AMERICAN GROWN, 991/2 PER CENT. PURE

We take great pride in recommending our SUPIRIOR AIFAIFA SFED to the Western farmer. Realizing its immense value and importance as a fodder crop in this section, we have given it our closest attention, sparing no effort to produce a seed that should be full and plump. and cleaning and recleaning it until it is as free from all noxious weed seed as human care can make it. IT STANDS THE HIGHEST GERIMINATION TESTS.

This is the only grade of Alfalfa Seed that we handle and you cannot afford to sow any other tind.

OUR SUPERIOR AIFAIFA in less than sack lots, per lb., $50 \mathrm{c} ; 10$ lbs., $\$ 4.75$; per 100 lbs., $\$ 45.00$.

\section{TURKESTAN}

\section{IMPORTED DRY LAND ALFALFA}

We make direct importations of this variety which comes from Central Asia and which is adapted to dry, unirrigated land. We suggest that it be seeded a little heavier than the ordinary type, as it is inclined to become coarse and woody; and thick sowing will produce finer plants. We can supply this in original package, or in smaller quantities. Lb., 50c; 10 lbs., \$4.75.

\section{TNOCUIATE THIS SEED WITH}

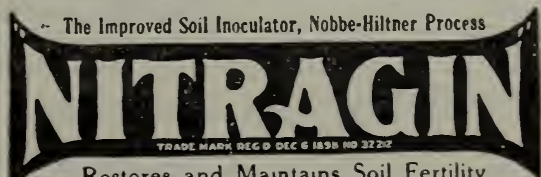

Restores and Maıntaıns Soil Fertility

BOOKLET MATIED FREE

$1 / 2$-acre size, 50c; 1 -acre size, $\$ 1.00$.

We do not pay express or freight charges on Clover or Grass Seeds. If order has to be pre paid do not fail to include charges. Small lots are cheaper by parcel post. Include postage. 


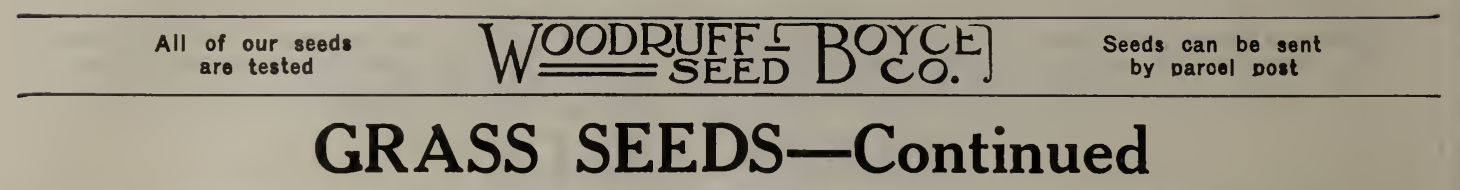

\section{YELLOW SWEET CLOVER OR BOKHARA}

This is an annual that is much used for plowing under as a fertilizer for alfalfa, but should be plowed under before it is allowed to seed.

It will yield a good crop wherever planted and is one of the best crops known for this purpose, as it is nitrogen giving. It is much like the White Sweet Clover but has yellowish blossoms. Very valuable as a bee pasture. Per lb., $45 \mathrm{c}$; 10 lbs., $\$ 3.50$.

\section{TIMOTHY SEED 991/2 Per Cent Pure}

The grade we offer is particularly "choice," free from weed seeds and of high germinating power. Timothy is the great standard hay grass of the Eastern part of the country. It makes hay of the best quality and produces a larger crop on good soll than any other grass. Not adapted for pasture, as there is little growth after cutting, and tramping of stock soon destroys it. Not a lawn grass and not adapted for dry solls; helght, 2 or 3 feet. Often sown with red top and red clover. Sow 15 to 20 lbs. Price fluctuates. Lb., 20 c; 10 lbs., $\$ 1.85 ; 100$ lbs., $\$ 18.00$.

\section{ENGLISH RYE GRASS}

It grows rapidly and makes a good showing within a month from time of sowing. The great pasture and meadow grass of Great Britain, and well adapted to the country west of the Cascades. Veluable for planting early on dry hillside. A good lawn grass but a little coarse. Sow 60 lbs. per acre. Lb., $25 \mathrm{c} ; 10$ lbs., $\$ 2.00 ; 100$ lbs., $\$ 17.00$

\section{ITALIAN RYE GRASS}

Thrives in almost any soil and yields early and abundant crops. Sown in the fall, will produce an excellent hay crop the following season, but lasts only one year. Not recommended for lawns. Sow 50 lbs. per acre. Lb., 25c; 10 lbs., $\$ 2.00 ; 100$ lbs., $\$ 17.00$.

\section{ORCHARD GRASS}

One of the most valuable of all pasture grasses produces an immense quantity of forage, and hay of best quality. After being sown, comes up quickly and yields very heavily. Suitable for pastare under trees. Not suitable for lawns, as it grows in tussocks. Sow $35 \mathrm{lbs}$. per acre. Lb., $40 \mathrm{c}$ 10 lbs., $\$ 3.50 ; 100$ lbs., $\$ 33.00$.

\section{RED TOP}

HERD'S GRASS. Second only to Timothy as a hay grass, and makes one of the best permanent pastures. Also valuable as a lawn grass, giving quick effect. Sow 40 lbs. to acre. In chaff, lb. $20 \mathrm{c} ; 10 \mathrm{lbs} ., \$ 1.75 ; 100$ lbs., $\$ 15.00$. Fancy, free from chaff, sow $15 \mathrm{lbs}$. to acre, $1 \mathrm{~b} ., 30 \mathrm{c}$; $10 \mathrm{lbs}$., $\$ 2.75 ; 100$ lbs., $\$ 25.00$.

We reserve the right to change prices on grase seeds and will notify you of any change before we ship.

\section{MEADOW FESCUE}

OR INGIISH BIUH CRASS. This is a valuable pasture grass as it roots deep and yields a heavy crop of excellent hay. Grows 3 to 4 foet high. Thrives best in damp locations. Lb., $35 \mathrm{c}$; 1.0 lbs., $\$ 3.25$.

\section{RED FESCUE}

Forms a close, rich and lasting sod. Valuable in golf and shade mixtures and may be used to bind dry banks. Sow 30 lbs. to acre. Lb., 60c; 10 lbs., $\$ 5.00$.

\section{TALL MEADOW OAT GRASS}

This wonderful grass often attains a height of 3 or 4 feet by the middle of June. Makes good hay that is relished by stock. Can be fed as pasture grass and is splendid for mixing with other grasses. Lb., $50 \mathrm{c}$; $10 \mathrm{lbs}$., $\$ 4.50$.

\section{SUDAN GRASS}

A valuable, drought-resisting forage plant introduced by the Department of Agriculture from the Sudan, Egypt, as being especially adapted to hot, dry sections, although it will stand quite a good deal of moisture. It is an annual but cannot be sown until the ground is warm in the spring. Grows very high and may be cut several times during the season. Stock like the hay and thrive upon it. Lb., 25c; 10 lbs., $\$ 2.50$.

\section{KENTUCKY BLUE GRASS}

Fancy or double; extra clean. As this grass takes some time to become established it is preferably sown in mixtures for pasturage. Is truly perennial and prefers lime soil. As a lawn grass it is the superior of any other grass, of spreading habit, even texture, permanent, fine leaf and dark color.

For pasture sow 50 lbs. to acre; for lawns, 4 or 5 lbs. for 1,000 sq. ft. Lb., $45 \mathrm{c} ; 10$ lbs., $\$ 4.00$

\section{PASTURE AND HAY MIXTURES}

\section{LOW OR WET LAND MIXTURE}

Contains grasses which do especially well on damp ground. Consists of the following grasses in the correct proportion: Meadow Fescue, Red Top, Alsike, English Rye Grass, Kentucky Blue Grass, Canadian Blue Grass, Red Clover, Rye Grass and Orchard Grass.

Lb., 30c; 10 lbs., $\$ 2.50 ; 100$ lbs., $\$ 22.50$

\section{HIGH OR DRY UPLAND MIXTURE}

The best mixture for Logged-off Land. Consists of the following grasses, in the correct proportion: White Clover, English Rye Grass, Italian Rye Grass, Canadian Blue Grass, Meadow Fescue and Kentucky Blue Grass.

Lb., 30c; 1 l lbs., $\$ 2.50 ; 100$ lbs., $\$ 22.50$.

\section{HAY MIXTURE}

Our Hay Mixture is a mixture especially recommended by agricultural experts, picoducing hay of prime quality and maturing evenly. Composed of Timothy, English Rye Grass, Red Clover, Meadow Fescue and Canadian Blue Grass.

Lb., $30 \mathrm{c} ; 10$ lbs., $\$ 2.50 ; 100$ lbs., $\$ 22.50$.

We reserve the right to change prices on grass seeds and will notify you of ax.y change before Page 36 
Plant beans and then more beans They will feed the army

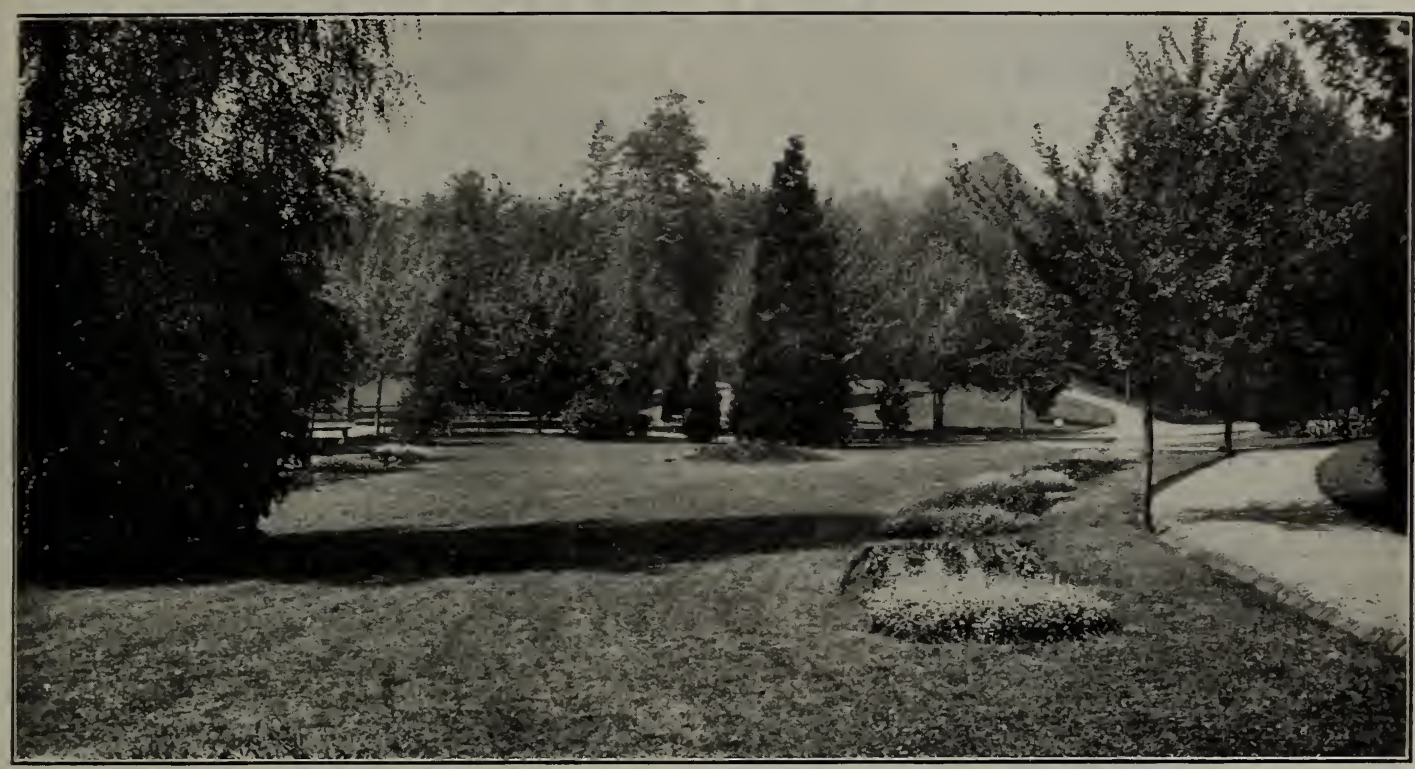

\section{LAWN ILAKING}

The soil should be spaded deep and well prepared. It should not be too rich, as a rapid growth is not wanted in grasses of a lawn, but the surface should be as much alike as possible. Sow the seed in two directions, then roll and cross roll in order to press the seed firmly into the soil. In about 10 days apply a light application of Woodruff's Lawn Fertilizer mixed with an equal part of good loam. This will serve to stimulate the young grasses. The best time for this is just before a rain, so that the fertilizer will be washed into the roots of the grass.

We are often asked when is the "best" time to plant a lawn. We know that from the middle of March until the end of June is the best time or the best lawn can be obtained with the least trouble and with less danger of a failure. Although we sell large quantities of grass seed all through the summer months, we advise people they must be more careful in planting and watering. The fall is a good time but great care should be taken so that your ground will be clear of weeds. Do not plant between November 15 and March 1st, as the ground is cold and seeds liable to decay.

ROIIING. Roll frequently, especially in the spring, as the winter frosts loosen the soil and rolling is necessary to compress it again.

MowING. Mow often, as it tends to improve the roots and the fineness of the texture. $B e$ careful in the summer time, as the roots require a covering during hot summer months.

Follow these directions and use our Superior Lawn Mixture and Superior Lawn Fertilizer and you will have your lawn talked about.

All Clover, Grass and Field Seeds are F. O. B. Seattle. If you desire them to come by parcel post add postage.

\section{LAWN SEEDS}

\section{SUPERIOR LAWN GRASS}

Our best lawn mixture for fine lawns. Contains chiefly our Superior Blue Grass, Creeping Bent, Bermuda Grass and White Clover. It is mixed in the proper proportion to make a good turf which will wear as no other will. Fine for improving old lawns. Lb., $45 \mathrm{c} ; 10 \mathrm{lbs}$., $\$ 4.00$.

\section{SUPERIOR BLUE GRASS}

Superior quality. The seed we will sell during the next year has been guaranteed to test $99 \%$ pure and germinates $87 \%$. This seed will weigh 29 pounds to the bushel. It forms a fine mat and with care and water is the best lawn grass for all soils except sandy ones. Lb., 40c; 10 lbs., $\$ 3.75$.

\section{TERRACE MIXTURE}

Just the mixture for the dry terrace slopes. Lb., $50 \mathrm{c} ; 10$ lbs., $\$ 4.50$.

\section{SUPERIOR WHITE CLOVER}

Unequaled for a lawn that will stand hard usage. It roots deeply and requires less water than lawn rrasses. In a mixture with Blue Grass it is very desirable. Valuable in permanent pastures as its foliage is sweet and nutritious. In mixtures 1 to 2 pounds, alone 8 to $10 \mathrm{lbs}$. to acre. Lb., $75 \mathrm{c}$; 10 lbs., $\$ 7.00$.

\section{SUPERIOR BENT GRASS}

A splendid grass in lawn mixtures. Its creeping, rooting stems form a tough, compact turf that is improved by tramping. Equally good in pasture mixture. Lb., $75 \mathrm{c} ; 10$ lbs., $\$ 6.00$.

\section{SUPERIOR SHADE MIXTURE}

Especially mixed to obtain lawns in shady places and for such locations it is unequalled. Lb., $50 \mathrm{c}$ : 10 lbs., $\$ 4.50$.

IF TOUR GROUND IS TOO POOR TO GET A IAWN YOU MUST USE FERTIIIZERS. WE MAKE OUR OWN FERTIIIZERS AND THEY ARE BOUND TO PRODUCE RESUITS. WR EATE THEM ANAIYZED BY THE STATE AND FUII ANAIYSIS PLACED ON EVERY PACEAGE. 


\section{BARLEY}

\section{BEARDLESS BARLEY}

An extra selected strain entirely free from beards, making it much preferable for hay and on account of being so easy to handle best for grain. Price, $\$ 5.50$ per 100 lbs; less than sacks, $8 \mathrm{c}$ per $1 \mathrm{~b}$.

\section{COMMON BARLEY}

We always aim to have a nice, clean stock of good seed Barley on hand at all times. This is the common 6-row bearded type. Price, $\$ 5.00$ per 100-lbs.; less than sacks, 7c per lb.

\section{HULLESS, OR BALD BARLEY}

It is more productive than wheat and is earlier. It can be sown late with reasonable assurance of a crop. Makes a fine grain food for hogs and other stock. Price $\$ 5.50$ per 100 lbs. Less than sacks, 8c per $1 \mathrm{~b}$.

\section{BUCKWHEAT}

Buckwheat is a valuable crop that can be easily grown wherever wheat will grow, producing a good yield even on light or poor soil and under favorable conditions is very profitable, being in big demand for milling-and is also the best "Bee pasture."

Sow $36 \mathrm{lbs}$. per acre in drills, $48 \mathrm{lbs}$. broadcast. We recommend the Japanese variety. Common, lb., postpaid 20c; 100 lbs., $\$ 14.00$.

\section{SILVER HULL}

Of a light gray color, rounder than the common; has a thin husk; matures earlier and yields heavier. An excellent milling variety. Per lb., postpaid,20c; 100 lbs., $\$ 15.00$.

\section{JAPANESE}

Ripens early-is hardy and yields the largest crops. The grains are extra large, dark brown, very thin hulled and makes the highest grade of flour. Good seed stock has been very scarce for several seasons, but we now have a fine lot which we can offer at a very low price. Per lb., postpaid, $20 \mathrm{c}$; 100 lbs., $\$ 14.00$.

\section{OATS}

Use quality seeds to get the most out of your sround. Don't look at the price of the seed stock, for we are obliged to make an additional charge for labor we have expended in recleaning and electing the stock.

\section{SHADELAND SELECTED SWEDISH OATS}

More to Acre-Superior Quality

Our best stock grain, large, full and white. Husks light, straw hardy and extra large, making it stand up better. Worth the additional cost. We invite comparison and will furnish samples. $10 \mathrm{lbs} ., 75 \mathrm{c} ; 100 \mathrm{lbs}$., $\$ 5.00$, by express or freight.

\section{ABUNDANCE OATS}

This is a new hybrid variety of Oats that has come to us so highly recommended that we offer it to our patrons for a trial.

It matures from 10 to 15 days earlier than other varieties but has a splendid yield and the large, plump, heavy kernels are white and thin skinned. The root growth is heavy so it will stand drouth. The straw is strong and not liable to lodge. Per lb., $10 \mathrm{c}$; $10 \mathrm{lbs}$., $75 \mathrm{c} ; 100 \mathrm{lbs}$., $\$ 5.00$

\section{DANISH GIANT}

A splendid variety for Puget Sound country where season is short. Grass tall and sturdy and stands the stormy weather without losing the grain. We recommend this to be used with Field Peas and Vetch. 10 lbs., $75 \mathrm{c} ; 100$ lbs., $\$ 4.50$.

\section{OREGON GRAY WINTER}

Used exclusively for fall planting. $10 \mathrm{lbs} ., 60 \mathrm{c}$; 100 lbs., $\$ 5.00$, by express or freight.

\section{BLACK ALASKA WINTER OATS}

This is an exceedingly hardy winter variety which we consider does the best in Western Washington. It is a variety that stands the most severe winters and does extremely well when planted with Vetch. Price, $\$ 5.00$ per $100 \mathrm{lbs}$; less than sacks, $7 \mathrm{c}$ per lb.

\section{SEED WHEAT}

When ready to buy any variety of Seed Wheat, write us for quotations on quantity wanted or send in your order and we will give full value at lowest market price. The following are standard market varieties that are known as the most profitable and best yielding: Spring Wheat, Marquis, Blue Stem, Little Club, Winter Wheat, Fortyfold, Red Russian, Turkey Red. Lb., 15c, postpaid; $\$ 5.25$ per 100 lbs., freight or express.

\section{FORMALDEHYDE}

\section{A Preventive for Smut in Grain-Scab and Fungus Diseases of Potatoes.}

Formaldedyle is a clear chemical, resembling water, but has a peculiar odor. It is sold by the pound (pint). One pound is sufficient to treat 40 to 50 bushels of oats.

The following method is in general use: To treat 20 bushels requires $1 / 4$ pint of Formaldehyde diluted with 5 gals. of water. Spread the oats on a floor and sprinkle with the diluted solution. Then turn them twice with a scoop shovel. Allow to stand for 12 hours. Then spread to dry. Any quantity can be treated by using the same proportions. Oats thus treated will be entirely free from smut.

Price, pint, $60 \mathrm{c}$ 


\section{FIELD PEAS}

Field Peas are a very profitable crop and are rown here very extensively. They can be grown alone or with oats. When planted with grain and cut green they make a large amount of very rich feed; also very valuable for enriching the soil if plowed under. The dry peas make excellent hogfeed and are quite fattening. Sow, if alone, 120 pounds to the acre; if with other grain, 60 pounds.

\section{YELLOW CANADIAN}

This variety is the most profitable. It is hardy, early and very productive. Recleaned seed free from splits and small peas. Lb., 15c, postpaid; 100 lbs., $\$ 6.00$, by freight.

\section{BLUE PRUSSIAN}

This variety used quite extensively as a food. A big yielder. Lb., 20c, postpaid; 100 lbs., $\$ 8.00$, by freight.

\section{EXTRA FANCY SEED STOCK}

If you are growing to sell, by all means plant this, 100 lbs., $\$ 10.00$.

\section{RYE}

\section{MAIMMOTH RUSSIAN}

Rye is a valuable and hardy cropper, providing green forage in late fall and early spring. It matures more quickly than most other crops, and can be made to yield a good crop on soil that is too poor for other cereals. It is splendid to sow with vetch or field peas. In food value it is very similar to wheat and is a very good hog food.

$1 \mathrm{lb}$., $15 \mathrm{c}$, postpaid; $100 \mathrm{lbs}$., $\$ 5.00$, by freight or express.

\section{VETCHES}

\section{COIMION VETCH}

One of the best forage plants that can be grown on the Pacific Coast. Often called Fall Vetches. This is a species of the pea, and is grown very extensively in Western Washington. It furnishes an abundance of excellent feed either green or cut and cured for hay. The seed should be mixed with an equal weight of some variety of wheat, oats or rye having a stiff straw, and the mixture sown at the rate of two bushels per acre. Vetches weigh 70 pounds per bushel. Sow in the Fall or early Spring. Lb., 25c, postpaid; 100 lbs., $\$ 12.00$, by express or freight.

\section{WINTER SAND OR HAIRY VETCH}

Does best east of the mountains and may be sowed either fall or spring. $10 \mathrm{lbs} ., \$ 3.50 ; 100 \mathrm{lbs}$., $\$ 30.00$, by express or freight.

\section{DWARF ESSEX RAPE}

\section{SUMMER AND FALL FORAGE]}

Very valuable for poultry raisers for green feed. Sow rotation crops and you will have green feed at all times. Poultry men claim there is nothing better. Lb., $25 \mathrm{c}$, postpaid; 10 ibs., $\$ 2.00$, by express.

\section{THE DANISH MANGEL WURZEL, SLUDSTRUP}

The highest point of Mangel Culture has been reached in the production of THE SLUDSTRUP, which has repeatedly been awarded a first-class certificate, which makes it, without a doubt, the best Mangel in the world.

It is long, smooth, reddish-yellow in color, grows well above the ground, making it easy to pull, and the crop it yields is phenomenal.

You cannot do better than to put in a big crop of SLUDSTRUP and have quantities of fresh. nutritious and wholesome food during the winter months for stock and poultry.

Price, per oz., 15c; per lb., i0c, 10 lbs., $\$ 5.00$.

All Mangels postpaid.

Write us for special prices on large quantities.

For other Mangels see Stock Beets in Vegetable department of catalogue.

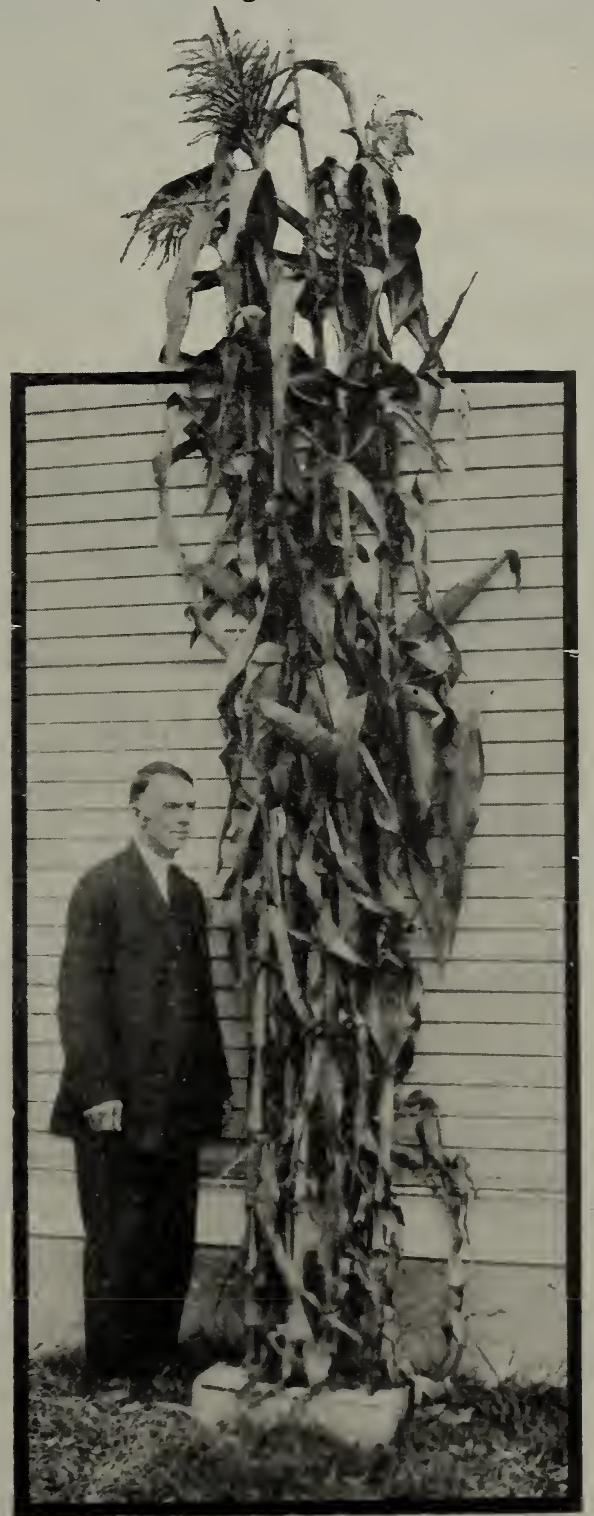

PRIDE OF THE NORTH

(See description on next page.) 


\begin{tabular}{|c|c|c|}
\hline $\begin{array}{c}\text { Our seeds insure you a } \\
\text { prolifio orop }\end{array}$ & WOODRUFF & $\begin{array}{c}\text { To plant too oarly } \\
\text { oauseo fallures } \\
\end{array}$ \\
\hline IELD CORN & on Gr & SEED \\
\hline
\end{tabular}

An early Yellow Dent Variety that has taken 10 years to bring to its present standard. This year seed was sown May 20 and harvested September 15, thus assuring a perfectly matured corn. The earn are good size and well filled with a heavy corn. Sold only on the ears and you can be assured of what you are getting. Per ear, 1 c: 10 ears, $\$ 1.25$, p istpaid.

\section{ENSILAGE CORN}

\section{PRIDE OF THE NORTH}

The picture on the preceding page gives a fair example of what you can expect from our Pride of the North. This was grown at Tolt, Wash., by E. W. Trezise.

Pride of the North has long been the standard Corn recommended by the Agricultural Stations as the best Yellow Dent for Western Washington, and our seed has given splendid results whenever conditions have been at all favorable, maturing early and yielding heavily, the foliage being luxuriant and of medium height. "Pride of the North" is specially recommended for silo. The ears are large and well filled and of a beautiful golden color.

\section{YELLOW GOLDEN DENT}

A northern grown Corn that has done exceedingly well in this locality. Exceedingly good for silos.

\section{IOWA GOLD MINE}

A splendid yellow dent variety. Does well in this locality.

\section{IMPROVED KING PHILLIP}

Extra Early Red Flint. Extremely hardy, and one of the best early sorts.

\section{WHITE DENT}

A good variety of White Corn that is the result of careful selecting. Fine for fodder.

\section{MINNESOTA NO. 13}

Grown extensively in Skagit County and has been known to mature very well.

\section{KING PHILLIP}

An early red flint which is exclusively used by some ranchors for ensilage.

All field corns, 20c lb., postpaid; 10 lbs., \$1.75; 25 lbs., $\$ 3.00 ; 100$ lbs., $\$ 12.00$, by express or freight.

\section{MILLETS \\ GERMAN OR GOLDEN}

A medium early variety, growing four to five feet high, and making a very good quality of hay or forage, although coarser than some varieties. Price, $\$ 9.50$ per 100 lbs., less than sack lots, $12 \mathrm{c}$ per $1 \mathrm{~b}$.

\section{HUNGARIAN MILLET}

Grows three or four feet high, with slender stems and abundant leaves, producing two or three tons of excellent hay per acre. Price, $\$ 9.50$ per 100 lbs., less than sack lots, $12 \mathrm{c}$ per $1 \mathrm{~b}$.

\section{JAPANESE BILLION DOLLAR}

Has given astonishing yields of both seed and fodder. It is very early and is claimed to be rust-proof. The fodder can be fed to horses and other stock without injury, even after the seed has formed, which cannot be done with safety with most of the millets. The seed is large and of a beautiful yellow color. Per lb., postpaid, $20 \mathrm{c} ; 100$ lbs., $\$ 9.50$.

\section{SOJA BEAN}

Valuable as a forage crop or green manure. Also as a green fodder and silo plant. Sow 30 pounds per acre after danger from frost is passed. Lb., $20 \mathrm{c} ; 100 \mathrm{lbs}$., $\$ 12.00$.

\section{WILD RICE}

\section{For Planting in Duck Ponds}

And around hunting grounds to furnish food for wild fowl, ducks, geese, etc. Fresh seed supplied in season. Write for information and prices.

Page 40

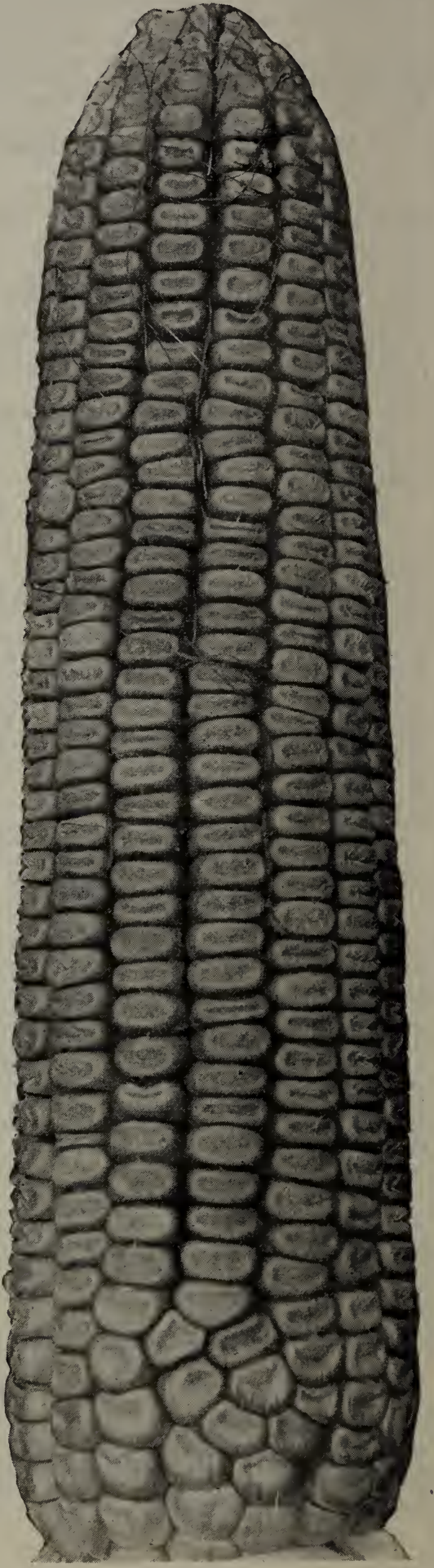




\section{TREATMENT OF FLOWER SEED}

There are no more satisfactory flowers than those grown from seed, especially the easily grown and brilliant flowered annuals. The beautiful shrubs and lilies, of course, have their place, but are lar more expensive than a paper of seed which will furnish a large number of plants with usually enough for one's garden and some to spare.

Aim to have your garden one artistic unit, with some flowers in bloom at all seasons, with colors which harmonize, and plants in size grading from the dwarf borders, to the bedding annuals, and then to the taller plants, which usually should stand next to the house or other confines of the garden or lawn. A garden carefully planned out and planted gives very much more pleasure than a haphazard one.

A perfect garden could not be made from seed alone; the grounds must have some shrubbery for Its permanent character. We have a nursery department, which supplies every need for private Frounds of all dimensions; see our list of trees and shrubs in the succeeding pages of this guide On the other hand no garden would be pretty or satisfactory which did not have a good number of lowers from our flower seed list most carefully chosen and placed in the garden.

\section{WHEN TO PLANT FLOWER SEED}

Perhaps you have noticed that many of the descriptions of flowers contain the words "annual," "hardy annual," "tender annual," "perennial," "tender perennial," etc. These may have seemed to Jou Hresome descriptions, but properly understood they tell much about planting.

RAT FABD means the plant will stand any light frost, but needs protection against very cold weather. These should be planted in the spring (March and April), not in the fall.

HARDY means the plant will stand considerable frost, or practically all we have on the Pacific Coast. These may be planted in the fall or in the spring (October to May). If sown in the fall they will come into bloom earlier than if sown in spring, even if the plants do not make much progress during the cold weather.

ANNUAIS are plants that bloom the first year from seed, and the plant dies after one season. Tender annuals must be sown in spring (April to June) and hardy annuals may be sown in either spring or fall (October to May).

BIIminats are plants that bloom the second year from seed, and the plant dies after the second year. On the Coast many of these will bloom the first year if sown early. Sow under same conditions as perennials.

PIRERNIAIS are plants that bloom the second year from seed, and the plant lives and blooms during successive years. If sown in early spring (February to April 15) many perennials will bloom the first year from seed. Tender and half-hardy perennials are best sown in spring after frost is over (April 15 to June). Hardy perennials are best sown in the late summer and early fall (July to October) for next year's flowers.

\section{HOW TO SOW FLOWER SEEDS}

The success from sowing seeds depends upon three things, the right amount of water, of air, and of heat, which means practically have your soil right as to moisture and texture. your seed sown at a proper depth and where the sunshine can furnish the heat. Soil that is hard and going to bake is not right to start seeds in. Take such soil in the fall and spade in manure or leaf mould and let it rot for several months and then work up fine. In the spring add to a heavy soil, that is clayey, soil peat or decayed leaf mould, and sand (sharp, fresh-water sand), so that there is one-third loam, one-third sand, and one-third leaf mould. This makes an excellent soil for starting fine seeds. For potting add a small amount of old sheep or cow manure.

\section{SEED IN THE OPEN}

Seeds of hardy annuals are sown directly in the bed where they are to remain, or they may be sown in boxes and transplanted. Have the ground well worked up and mixed with leaf mould, if needed. The soil should be well moistened, not wet and soggy, and not, by any means, dry when the seeds are sown. Put all medium-sized seeds at a depth of one-quarter to one-half inch. Sweet Peas should go deeper. Very fine seeds should be pressed into the soil and a little sand sifted over them. Water more frequently if the seed is close to the surface, and if necessary protect with cheesecloth while watering. Always press or fire the soil after sowing any seed. These seed are best sown in the open so as not to be transplanted, Eschscholtzia, Nasturtium, Poppy, also very many others, may be profitably so sown.

If the seed be sown directly in the garden, it should be sown in the spring after the soil is well worked and when in moist condition. A slight depression should be made with a stick, the seed sown and then covered with sandy loam about twice the depth of the diameter of the seed. The seed will prevent the crusting over of the soil after watering.

When up, the plants must be thinned from two to twelve inches, depending on the variety, otherwise they will be weak and spindling. It is a common mistake in the garden to leave plants altogether too thick. Always keep the weeds out.

\section{SEEDS IN BOXES}

Always use care in getting a good loam as described. Use no manure in any seed box. Boxes 4 inches deep and $18 \times 24$ inches is the usual size. See that good drainage is provided by boring holes in the bottom, fill with the fine prepared soll which should be moist, but not wet enough to stick together when squeezed with the hand. Sow the seed about one-quarter inch deep except fine seeds. Water, so as to keep the soil always just moist. Water carefully and regularly. A pane of glass over the box adds more heat, protects from draughts, prevents drying out, but is not necessary except for difficult seeds. The box should be in the sunlight. Then the plants are in third or fourth leaf they should be picked out and reset in another box with plenty of room, for it is important that the plant be of good size, strong and sturdy, when finally transplanted in the garden.

Another mistake in sowing flower, as well as other seed, is covering too deep. As a general rule, cover only to the depth of the thickness of the seeds; or, with medium-sized seeds, like Balsams, Zinnias, etc., one-quarter to one-half inch is the proper depth. Such fine seeds as Portulacas, Nicotiana, etc., need only to be pressed into the soil with a piece of board or the palm of the hand. Always press the earth down firmly after sowing all flower seeds, else there is danger of their drying up before the roots can get firm hold of the soil. Seeds of the hardier annuals may be sown where they are to grow; but, often, it is preferable to transplant. When the seedlings are first set out they should be watered frequently and should be protected from too much sunlight and from heavy rains. Provide vome support from all such annuals as require it. 


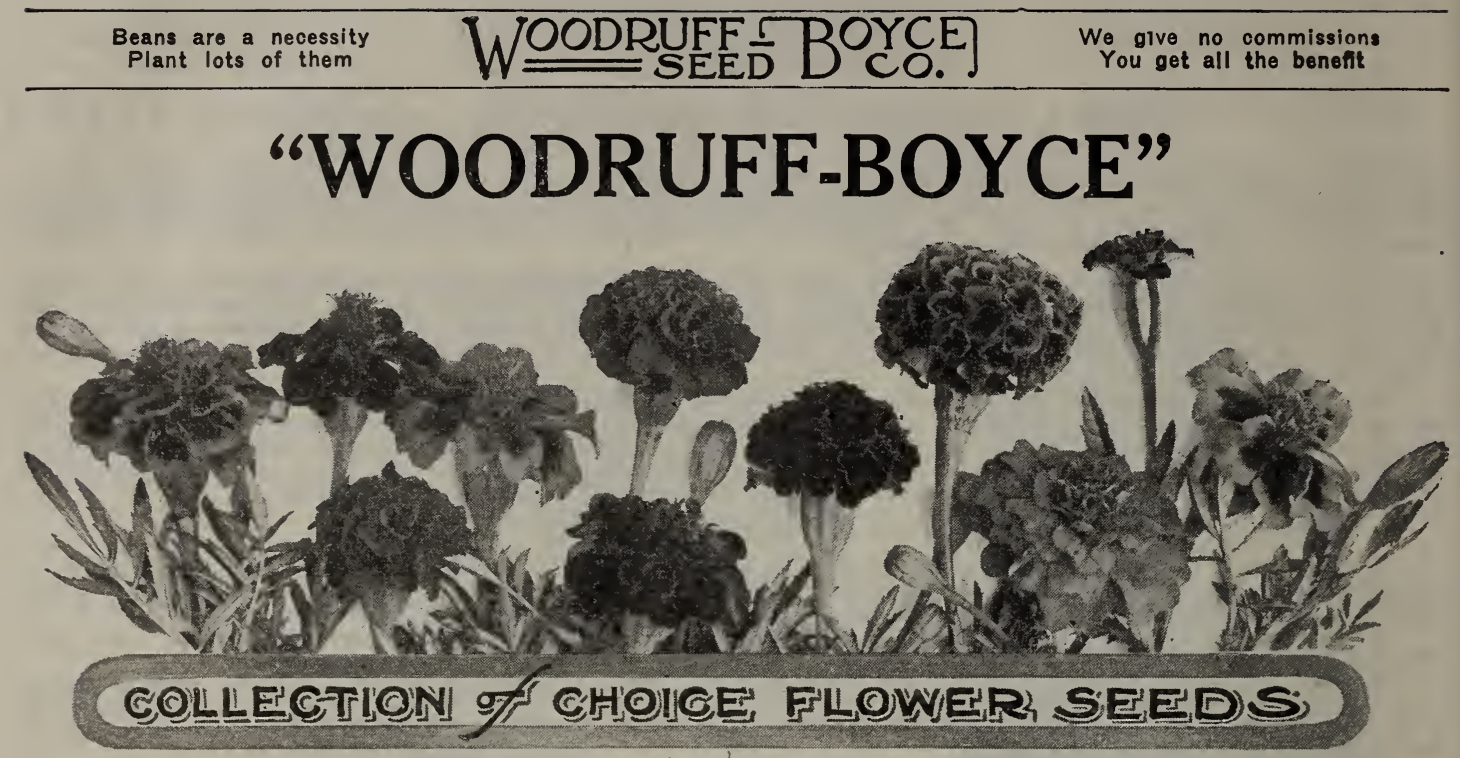

\section{ASTERS}

We are offering below a variety of Asters that cannot be excelled anywhere. Besides the BranchIng Asters, we have the well known Comet, Hercules, Victoria and Elegance. The best results are obtained by planting in boxes and transplanting, although they can be raised successfully by planting outside in the open ground.

\section{ASTER, NEW FNGIAND PERENNIAL}

(Michaelma Daisy).

A splendid flower, grows 4 to 5 feet. Hardy and a wild flower in New England. A very handsome flower. Mixed colors, pkt., $15 \mathrm{c}$.

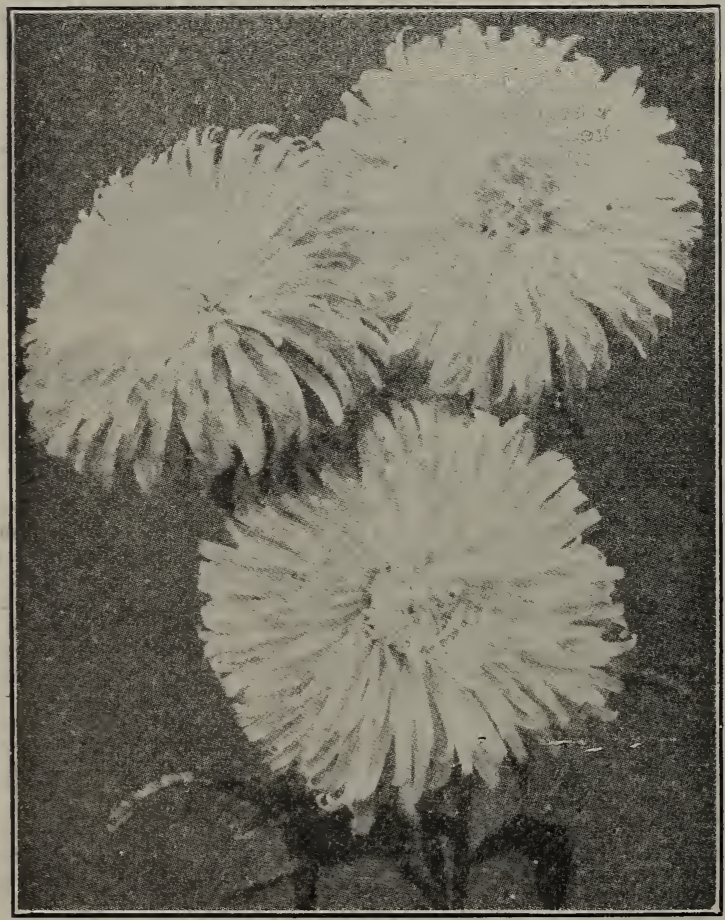

IATE BRANCFING ASTER.
ASTER SEMPLE OR GIANT BRANCHING. This is the favorite amongst the Branching Asters. It is a well known variety and does very well in this locality. The flowers are large, and the coloring exquisite. White, lavender, pink, dark blue. Pkt., $10 \mathrm{c}$; or a mixture containing all colors, pkt., $10 \mathrm{c}$.

\section{IATE BRANCHING ASTTR.}

Any one who likes long-stemmed branching Asters wants this magnificent Aster. Flowers usually 4 and sometimes 5 inches across, very double ard as fine as any chrysanthemum. We consider this the finest Aster there is and culture the same as other Asters.

SEMPIES SEA SHEII PINK, pkt., $15 \mathrm{c}$.

WHITE, pkt., $15 \mathrm{c}$.

IAVENDER, pkt., $15 \mathrm{c}$

ROSE, pkt., $15 \mathrm{c}$.

PURPLE, pkt., $15 \mathrm{c}$.

COLIECTION of one of each of the five for $50 \mathrm{c}$.

GIANT COMET ASTIR. A taller variety of the Comet type with branching stems and very valuable for cutting. White, peach blossom, scarlet, dark blue, in separate colors, and these varieties in a mixture. Pkt., 10c; or 4 varieties for $30 \mathrm{c}$.

HERCUIES ASTER. One of Benary's most modern introductions. It has long curly petals which droop and curl gracefully from the center and resembles a Chrysanthemum and often measures 5 inches across. They need rich soil and careful attention to bring out these results. Pkt., $25 \mathrm{c}$.

SINGIE EIFGANCE. Something new and very fine. Only in mixed colors. Pkt., $10 \mathrm{c}$.

SINGIE JAPANESE. One of the best varieties of single Asters that has ever been introduced. It is truly a wonderful flower and as Asters are so easily cultivated every lover of flowers should try a package. Pkt., $15 \mathrm{c}$.

VICTORIA. One of the best bedding varieties of the smaller sized blossoms. They grow from 12 to 14 inches high, and are great bloomers. White, rose and blue. Pkt., $5 \mathrm{c}$; mixture of all colors, pkt., $5 \mathrm{c}$. 


\section{FLOWER SEEDS-.-Continued}

ABRONIA (Sand Verbena). A hardy annual trailing in habit, about nine inches high, bearing verbena like clusters of flowers. Thrives in dry places and valuable in rock work and hanging baskets. Pkt., $5 \mathrm{c}$.

ACACIA ARMATA. A good pot plant. In high repute for decorative purposes. Also called Kangaroo Thorn. Price, per pkt., 5c.

ACFIIIEA (The Pearl of Sneezewort). One of the best hardy perennials, bears a profusion of small double, white flowers the entire season. Fine for cutting. Pkt., $15 \mathrm{c}$.

ACANTHUS SPINOSUS (Bear's Breach). A fine perennial and a very effective flower, does well in shady places. Pkt., $5 \mathrm{c}$.

ACROCIINIUM. Very pretty annual producing white and rose colored daisy-like flowers in August and September. They are the Immortelles so desired for wreaths and fall bouquets. One foot high. White, pkt., 5c; Rose, pkt., 5c.

ACROSTEMMA (Rose of Heaven). This plant has silvery white leaves and red flowers, borne on long slender stems; flowers resemble a single pink. Two feet high. Perennial, mixed colors. pkt., 5 c.

ADIUMA CIRRHOSA (Mountain Fringe or Allegheny $V$ ine). An attractive and beautiful hardy climber, biennial, flowering the first season, clusters of small rosy lilac flowers and pale green feathery foliage. Grows 15 feet tall. Pkt., 10c.

ADONIS (Floss Adonis or Pheasant's Eye). A hardy annual of easy culture, growing about one foot high. Leaves fine cut and feathery, flowers crimson. Pkt., 5c.

AGRRATUM. A hardy annual of easy culture, especially valuable for bedding, as it is literally covered with blossoms all summer. Sow the seed early in the spring, either in boxes or transplant.

AIOrSOA. This is a bright scarlet annual about 10 inches high. The flowers are borne in twos and threes along the stems; suitable for the border. Treat as half-hardy annual.

AIYSSUM. A fragrant, hardy annual, having the odor of honey and bearing spikes of small white flowers in great profusion throughout the summer and autumn. Useful for borders or early bedding flowers. Sow the seed early in the spring.

COMMON SWErT AIYSSUM, pkt., $5 \mathrm{c}$; oz., $30 \mathrm{c}$. I.TTIE GEM. 3 to 4 inches high. Pkt., 5c; oz., $50 \mathrm{c}$

DWARF BOUQUET. Highly scented; something new. Pkt., 10c. $5 c$.

SAXATIIE. A yellowish sort, perennial. Pkt.,

BENTHAMI COMPACTUM. A very dwarf growing Alyssum that is especially recommended for borders. This is a better type than the common flower. We have a small lot of this selected seed. Pkt., $15 \mathrm{c}$.

IOVE IIES BIEEDING. Foliage light yellowish green, crimson flowers. Pkt., 5c.

PRINCE'S FEATHERS. Tall spikes of feathery red flowers. Pkt., 5c.

JOSEPE'S COAT. Foliage variegated red, yellow and green. Pkt. $5 \mathrm{c}$.

AMARANTHUS. Hardy annual. grown especially for their brilliant foliage. Pkt., $5 \mathrm{c}$.

ANEMONE. A half-hardy perennial cup-shaped flower in blue, red and white; comes into bloom in May and June. Pkt., 5c.

ANCEUSA. A hardy annual, bearing blue forget-me-not-like flowers. Pkt., 5c. Flesh color, Pkt., $5 \mathrm{c}$.

\section{ANTIRRHINUMS OR SNAP DRAGON}

This immensely popular flower is a direct descendant of the quaint Snapdragon of old, but so enlarged and improved in the variety and richness of coloring as to be in an entirely different class.

They cannot be surpassed either for bedding or cut flowers.

QUEEN VICTORIA. White. Pkt., $15 \mathrm{c}$. QUErN VICTORIA. Scarlet. Pkt., 10c. QUEFN VICTORIA. Carmine. Pkt., 10c. QUEEN VICTORIA. Coral Red. Pkt., 10c. QUERN VICTORIA. Yellow. Pkt., $10 \mathrm{c}$. BEST MIXED. Pkt., 10c.

NANUM. Scarlet. Pkt., 10c.

NANUIr. Brilliant Rose Pink. Pkt., 10c.

NANUM. Canary Yellow. Pkt., 10c.

DEFIAITCE. Scarlet. Pkt., 10c.

DEFIANCE. Soft Pink. Pkt., 10c.

DEFIANCE. Pure White. Pkt., 10c.

vENUS. Soft Pink, White Throat. Pkt., 10c.

OTF[IIO. A splendid new variety, of which there is no more satisfactory flower for the garden. Pkt., 10c.

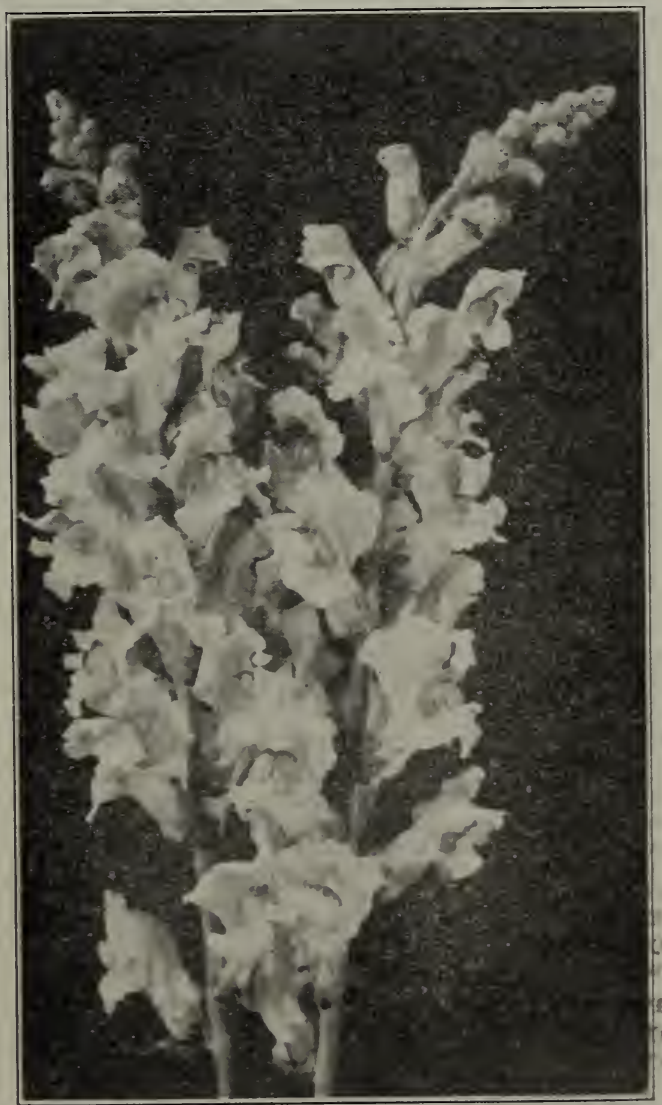




\section{FLOWER SEEDS-Continued}

ARABIS AIPINA. A white, early blooming flower, called Snow in the Mountain; a beautiful perennial that does well in this location. Pkt., 10c.

ARCTOTIS GRANDIS (African Daisy). A remarkably handsome and effective annual, of branched habit, 2 to $21 / 2$ feet in height and breadth. The flowers are long-stemmed, large and showy, being white on the upper surface with yellow zone in center and under side of petals a pale lilac blue. Pkt., $10 \mathrm{c}$.

ASPARAGUS. The well known Asparagus fern used for decorating and in bouquets can be easily grown with a little extra care. Seeds start slowly and should be soaked in warm water before sowing.

PIUMosus. The tall Asparagus fern with delicate, feathery foliage. Pkt., $10 \mathrm{c} ; 25$ seeds, $25 \mathrm{c}$.

SPRENGFRI. An early, easily grown, featheryleaved variety, especially for hanging baskets. Pkt., $10 \mathrm{c}$; 30 seeds, $25 \mathrm{c}$.

ASPERUIA ODORATA (Woodruff New MOWn Hay). The dried leaves and stems are very fragrant. Ferennial white, sweet scented. Height 4 inches. Pkt., 15c.

AURICUIA (Primula Auricula). A great favorite in England where flower shows are held of this plant alone. It is not very well known here, but is fast coming into popularity. Extra choice seeds for displaying. Pkt., $15 \mathrm{c}$

BAIIOON VINF (Iove-in-a-puff). Climbing annual, flowers small, but the seed pods are curiously swelled and quite attractive. Pkt., 5c.

BAISAII (Iady's slipper). A tender annual with brittle stems and foliage. Grows twelve inches high. Flowers, both single and double in very bright colors, are waxy and very attractive. Double varieties, rose, scarlet and lilac. Pkt., 10c.

BEGONIA. Usually grown from bulbs. See Bulbs.

BIGNONIA. (Trumpet Flower). A fine climber for conservatory decoration and warm situations in the garden. Seeds must be sown in heat early in spring. Pkt., $10 \mathrm{c}$.

BROWAIIIA. A half-hardy annual making a ine bedding plant; blooms profusely. The flowers are bright ultra-marine blue, and also sky blue with white centers. Pkt., 5c.

CACAIIA (Tassel Flower or Flora's Paint Brush). A neat annual of easy culture, with tassel-shaped flowers, blooms from June to September; fine for borders. Golden-yellow and scarlet mixed; $1 \frac{1}{2}$ feet. Pkt., $10 \mathrm{c}$

CAIAMPEIS, also called BUGIE VINE. Climber for verandas, trellises, etc. Handsome racemes of bloom. Perennial. Sow indoors to bloom the first season out of doors. Pkt., 10c.

CAICEOIARIA. A tender perennial used largely in hot houses and conservatories. Bears great quantities of small flowers, which are beautifully tigered and spotted. Pkt., 25c.

OAIFNDUIA (Pot-Marigold). Very hardy annual, blooms freely and lasts for several months. It is of easy culture and thrives well in poor soil, where less sturdy flowers do poorly. Mixed. Plat., 5c.

CAIFNDUIA MrTFOR. Large, double yellow flowers, striped with orange. Pkt., 5c.

PRINCE GEORGP. A fine, deep scarlet. Pkt., 5c.

CAIrIOPSIS. A hardy annual, growing about three feet high and valuable for bright bedding effects. Blossoms single and about three inches in diameter. Mixed. Pkt., 5c.

CAIIIOPSIS ATKINSONI. Yellow and brown, a selected strain. Pkt., 10c.

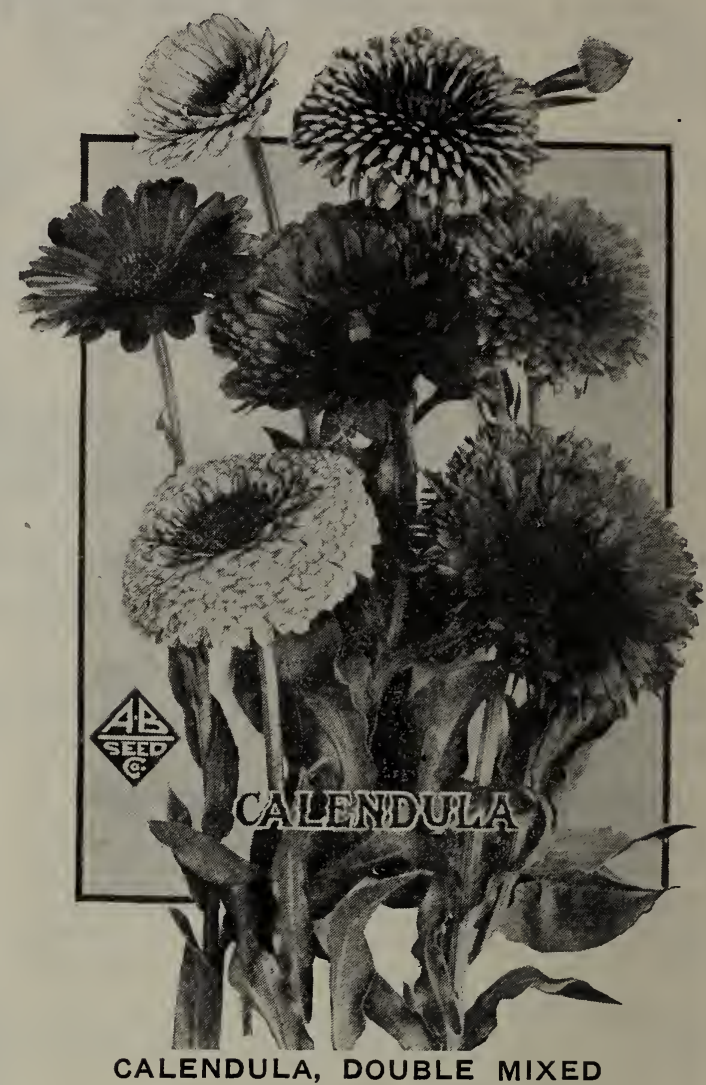

CANARY BIRD FIOWER. A tender climbing annual of the Nasturtium family. Blossoms have curiously winged petals and are light yellow. Pkt., 5c.

CANDYTUTT. A hardy annual, growing from 6 to 10 inches high, according to the variety. It is amongst the most highly prized of garden annuals. Grows easily and does exceedingly well in this locality. Excellent for borders, bedding or masses.

WHITE FMPRESS. Very large heads and long spikes. Pkt., 10c; oz., 50c.

GIBRAITARICA. A perennial lilac shading to white. Pkt., 10c.

COMMON SWEET-SCENTED VARIETY. Pkt. 5c.; Oz., 20c

CARMINE-PURPIE, Or WHITE ROCKET. Pkt., $5 \mathrm{c} ;$ oz., $40 \mathrm{c}$.

CANCEOIATA GRANDIFIORA. Perennial. No flower lasts as long as this one. Flowers bright yellow, last well and a very satisfactory flower. Grows easily from seed. Pkt., 10c.

CANTERBURY BELI (Campanula). A hardy biennial that usually flowers the first year from seed. They are very ornamental, producing large bell shaped flowers of exquisite shades. Single varieties of white, blue, purple and red flowers. Pkt., 10c; mixed varieties, pkt., $5 \mathrm{c}$.

CUP AND SAUCER TYPES. Blue, rose, light blue and mixed. Pkt., $10 \mathrm{c}$.

CARINATUM NORTHERN STAR. Single giant flowers of white with soft yellow zone against a bold black disk. Pkt., 5c. 


\section{FLOWER SEEDS-Continued}

\section{CARNATIONS}

General favorites for their delicious fragrance and richness of color. They are indispensable, both for greenhouse culture in winter and for the garden in summer. The Marguerte and Chabaud's type are the best for summer flowering.

\section{MARGUERITE CARNATIONS}

These are deservedly the most popular Carnations with the amateur, as they begin flowering in a few weeks from time of sowing. The strain offered is of extra fine quality, producing on long, strong few weeks from time of sowing. The strain ofly fringed, highly scented flowers; with slight protection stems an abundance of large, double, beautifuly fringeely the following spring.

they will survive an ordinary

YEIIOW. Pkt., 10c.

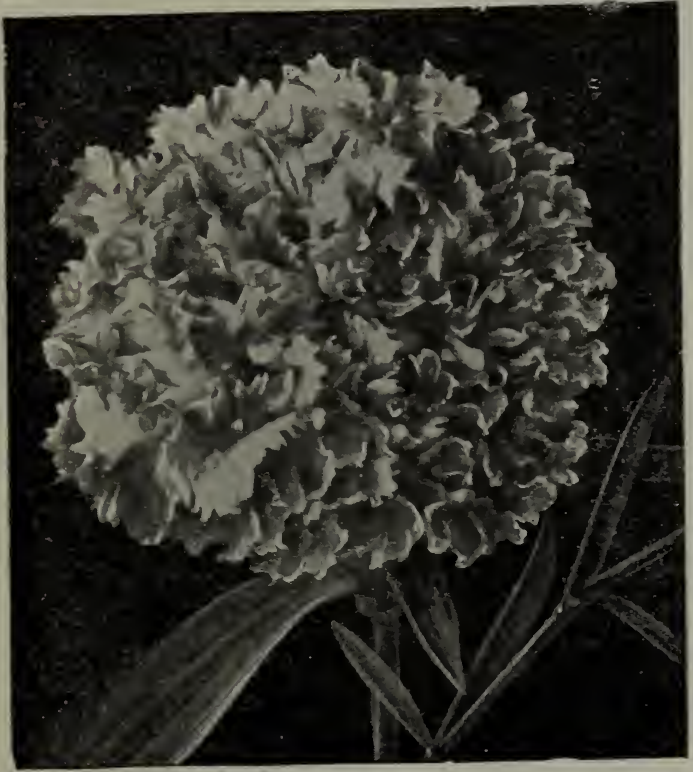

MARGUERITE CARNATION

GRENADIN CARNATION. Extra select double border Carnations; wnite, scarlet and mixed. Pkt., $15 \mathrm{c}$.

GRENADIN SCARIET. A selected seed. Blooms freely and early and especially fine for borders. Pkt., 15c.

CARDINAI CIIMBER. A climber of real merit, grows thirty feet and bears a mass of fiery cardinal red flowers. Plant late. as the seeds require warm weather to start. Pkt., $25 \mathrm{c}$.

CASTOR OII BEAN Or RICINOS. A tender annual growing from six to fifteen feet high, bearing a variety of colored leaves. Grows very easily. Pkt.. 5c.

Criosia or COCKscome. A half-hardy annual growing 6 to 8 inches high, bearing a wide wavy blossom that resembles a cockscomb. Dwarf mixed: several shades of red and yellow mixed. Pkt., 10c.

PİUMOSA THOMSONI MAGNIFICA. Ranging in color from clearest yellow to darkest blood red. Pkt., $5 \mathrm{c}$.

MAGNIFICENT CRIMSON. A very bright color. Pkt., 10c.

MAGNIFICENT GOIDEN YEIIOW. A fine contrast to the Crimson. Pkt., 10c.

CENTAUREA. A hardy annual embracing a number of species, some being grown only for their foliage. See Bachelor's Button, Sweet Sultan, Royal and Dusty Miller. Pkt., 5c.
All of above colored mixed, pkt., 10c.

\section{CHRYSANTHEIMUMS}

See the plant department for the Hybrid varieties. The ones below listed are the annuals.

PAINTED DAISY. Grows from one to one and

one-half feet high; grows easily and is very attractive. Pkt., 5c.

TRICOIOR. These are large, single flowered sorts, with colors in rings, mixed. Pkt., 5c.

HAIF DWARF. Of compact growth; flowers large, abundant and later than many sorts. White, scarlet, lilac, rose or mixed. Pkt., $10 \mathrm{c}$.

IORD BEACONFIEID. A white outside growing flower that gives very good satisfaction. Pkt., $10 \mathrm{c}$.

GOIDEN FEATHER. A very large, fluffy, yellow chrysanthemum that we can recommend. Pkt. $10 \mathrm{c}$.

VENUSTUM. A rose variety which goes well with the white and yellow. Pkt., 10c.

CANNA CROZY. Mixture of the popular varieties of the new type. Flowers red and yellow: foliage very large and striking. Pkt., 10c.

CINERARIA. Magnificent and an indispensable flowering plant for the conservatory or window garden. The flowers measure 2 to 3 incres across are of white, blue, violet and crimson shades usually two or more colors are shown in one flower. Double Large Flowering, mixed. Pkt., $25 \mathrm{c}$.

CIARKIA. A hardy annual of easy culture, growing about eighteen inches high, bearing bright. double rose, white or purple flowers in great profusion. Seeds can be sown almost any time

Pkt., 5c.

BRIIIIANT CARMINE. Pkt., $5 \mathrm{c}$

SAIMON QUEEN. Pkt., 5c.

PUICHEIIA AIBA FI. PI. Pkt., 5c.

PUICHEIIA RUBRA. Pkt., 5c.

COBOEA SCANDENS. A half-hardy climbing perennial with large leaves, and bell-shaped flowers. Grows 20 feet and is very valuable for cover. ing lattice and fences. (Plants in season.) Pkt., $10 \mathrm{c}$.

\section{AGUILEGIA}

COIUMBINE and sometimes called HONEY. SUCKIE. No garden is complete without some of these graceful flowers. It thrives in partial shade and moist places. Pkt., $5 \mathrm{c}$.

CAIIFORNIA HYBRIDA. Exquisite flowers in yellow and orange shades. Pkt., $5 \mathrm{c}$.

COERUIEA HYBRIDA. Beautiful hybrids that bear large flowers in a variety of colors. Pkt., $5 \mathrm{c}$. AIPINA SUPERBA. Pkt., 5c.

VUIGARIS (Double mixed). Pkt., 5c. VUIGARIS (Single arixed). Pkt., 5c. IAETSCEAUI. Pkt., 10c.

corrus. A tender perennial, quite Impossible to start outside of a green house. Plants in season. Pkt., $25 \mathrm{c}$.

EXBETD GRANDIPIORA. Blood red. Pkt., $50 \mathrm{c}$. 


\section{FLOWER SEEDS - Continued}

CoNvorvULUS (See Morning Glory). A tender bulbous perennial, used in green houses and window gardens. It can be grown from seed with a little care. Sow in fall or early in the spring. Mixed, pkt., 10 seeds, $25 \mathrm{c}$.

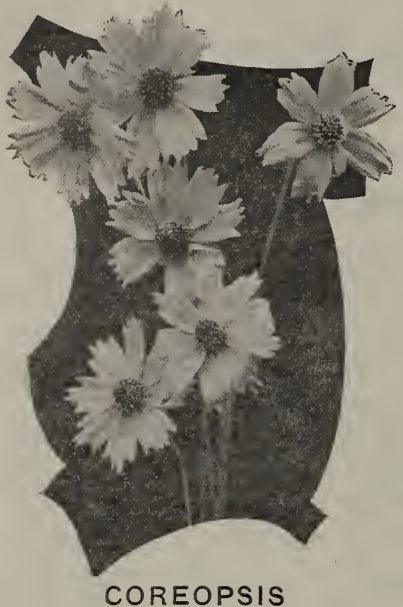

COREOPSIS. A hardy perennial about two feet high. This produces an abundance of $1 \mathrm{arge}$, daisy-shaped flowers on long stems. One of the best of the perennials for cut flowers. Pkt., $10 \mathrm{c}$.

CORNFLOWER. Bachelor's Button, Ragged Sailor, or Bluebottle. An old-fashioned favorite. Hardy annual. Two feet high. Pkt., 5c.

\section{COSIMOS}

Cosmos is the showiest of our late summer and Autumn blooming annuals. Its graceful flowers borne on long stems, rising above the feathery foliage, are very desirable for home or church decoration, lasting a week or more in water. It is a very prolific bloomer and if the plants are given enough space to develop well, will branch freelv, every shoot being covered with a mass of lovely flowers. It may be transplanted any time until shortly before blooming.

KLONDYKE. Golden Yellow flowers on extra long stems that make this variety especially good for cutting. Pkt., $5 \mathrm{c}$.

IADY LENOX. This is the newest and most improved strain. The flowers are extra large and they are borne on very long stems.

EXTRA CHOICE. Pkt., 10c.

BIPINNATA ALBA. White. Pkt., 5c.

BIPINNATA ROSEA. Pink. Pkt., $5 \mathrm{c}$.

BIPINNATA CRIMSON RAY. Pkt., $5 \mathrm{c}$.

BIPINNATA PUYSUREA. Pkt., 5c.

Cosmos. Common mixed. Pkt., $10 \mathrm{c}$.

GRANDIFLORA MAMMOTH. Late flowering pink, crimson, white and mixed. Pkt., 10c.

CYCIAMIEN, GIANT FLOWERED. One of the most beautiful and popular of the winter blooming plants that we have. It has beautiful foliage and an abundance of richly colored flowers. Seed may be sown either Spring or Autumn. Pkt., $25 \mathrm{c}$.

CYPRESS VINE. A tender climbing annual. Grows rapidly. Has handsome fern-like foliage and brilliant, attractive flowers. White, scarlet or mixed. Pkt., 5 c.

Prge 46

\section{DAHLIAS}

Some of the newest and best varieties of the well known flower have been produced from seeds. We have endeavored to obtain the best to be had and one can sow early and you will have flowers the same year.

CACTUS. Mixed colors. Pkt., 10c.

DOUBLE, which includes Show and Pom. pon. Pkt., 10c.

SINGLE. This variety does the best when planted from seed. Pkt., 10c.

\section{DAISIES}

BELIIS PERENNIS (Double Daisy). The little daisy we all like growing in our lawns, used extensively for borders. A hardy perennial that improves with cultivation. Red, white and pink. Pkt., 10c; mixed colors, pkt., 10c.

SFASTA DAISY. A fine perennial plant bearing large white single blossoms with yellow centers. Soak seeds in warm water before planting. Pkt., 15c.

ALASKA DAISY. One of Burbank's new Daisies. Pkt., 25c.

DIMORPHOTECA (African Golden Daisy). An extremely showy annual Daisy from South Africa which suits our climatic conditions perfectly. The bushy plants grow 12 to 15 inches high. The flowers, which are $21 / 2$ inches and over across, are a unique, rich, glossy orange-gold, with dark disc and halo. These glitter in the sunshine and present a magnificent sight when in full bloom. Seed may be sown in the same way as Asters or Petunias, and should have a dry, sunny position. They bloom the greater part of the summer and fall. Pkt., $25 \mathrm{c}$.

GIANT MONSTROSA (Finest Daisy). A new and giant flowering daisy. The flowers are from 2 to 3 inches across, stems long and can be used as a cut flower. Colors, white, light rose, red. Pkt., 25c.

SNOWBALL. Pkt., 25c.

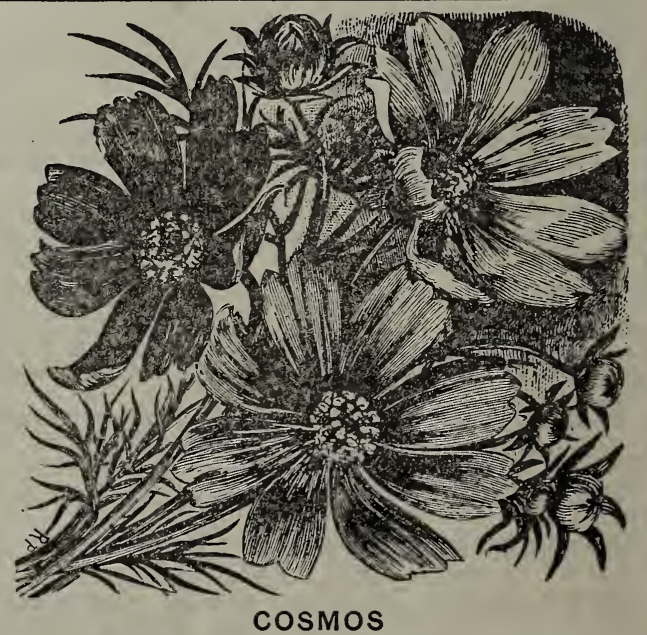

DATURA (Trumpet Flower or Horn of Plenty). A hardy annual growing three feet high. Flowers large and trumpet shaped. Pkt., 5c. 
Hoover says "Eat lots of vegetables" They'll save the meat

\section{FLOWER SEEDS - Continued}

DEIPAINTUM. See Larkspur.

\section{DIANTHUS, OR PINKS}

One of the most popular and magnificent flowers in cultivation, producing a great variety of brilliant colors and profusion of bloom. The annual varieties may be sown out of doors when danger from frost is past and in a few weeks time they are a mass of bloom, continuing so until frost.

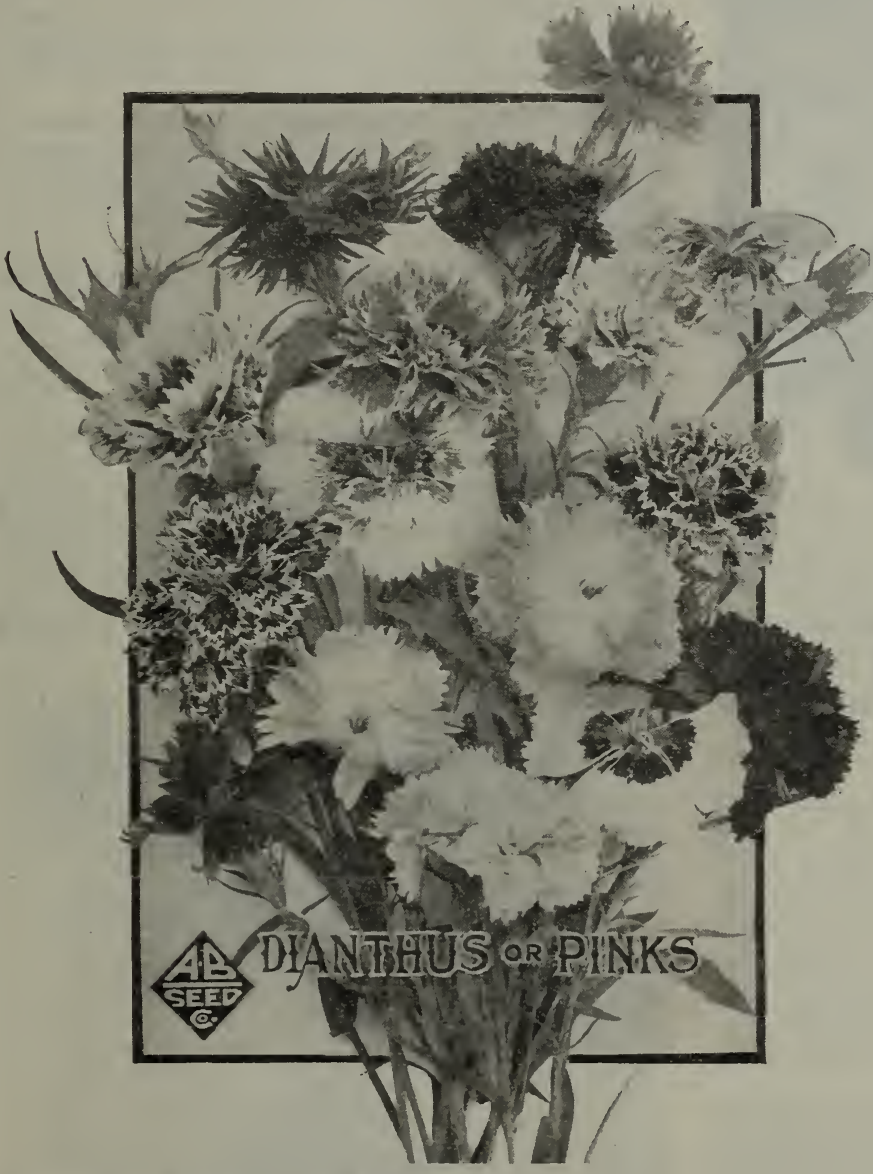

DOUBIE ANNUAI PINKS, MIXED. A fancy mixture of beautiful varieties. Oz., $60 \mathrm{c}$; pkt., $5 \mathrm{c}$.

DIANTHUS-DOUBIE IUCIFER. This new annual Pink represents the double flowered form of the Dianthus Vesuvius. The nicely fringed double flowers, $13 / 4$ to 2 inches across, are of an intense orange-scarlet, a dazzling color in full sunshine and the most striking of all red flowered annual Pinks. The plants grow 12 to 15 inches high and may be advantageously used for effective flower-beds. We are certain that the flowers of this new variety will be of the same great value and importance for cutting among the annual Pinks, as the bright scarlet flowered variety "Grenadin" has attained among Carnations. Pkt., $25 \mathrm{c}$

SINGIE ANNUAI PINKS, MIXID. A beautiful mixture of all the single varieties. Oz., $50 \mathrm{c}$; pkt., $5 \mathrm{c}$.

HARDY GARDEN PINRS. Fancy mixed. Contains all the desirable colors. $1 / 4$ oz., $50 \mathrm{c}$; pkt., $15 \mathrm{c}$.
DIGITAIIS (Fozglove). A hardy perennial, blooming the second year from seed. The bell-shaped flowers are borne on long spikes and come in shades of purple, lavender, yellow, rose and white. Thrives best in cool, shady places. Fine mixed, pkt., $5 \mathrm{c}$.

YELIOW. One of the favorite colors. Pkt., $10 \mathrm{c}$.

DOIICHOS. An annual climber with Wisteria-like blossoms followed by bronze-purple seed pods. Grows 10 feet high.

DAYIIGHT. Very quick growing and the foliage is not affected by insect pests. Largo clusters of white blossoms. Pkt., 5c.

Darkness. Same as Daylight, but with rich purple-violet blossoms. Pkt., 5c.

DORONICUM. An effective early flowering perennial. Thick, heavy stems supporting enormous daisylike flowers with fine petals. Splendid for cutting, and especially effective when massed in the garden. Pkt., 10c.

CAUCASSIUM. Very free flowering. Bright yellow. Pkt., 10c.

DUSTY MIIIFR (Centaurea Gymnocarpa). Silvery - white, leaves broadly cut, very popular foliage plant for bedding, hanging baskets and pots. Extensively used for edging. Sow early indoors and transplant after all danger of frost has passed. Pkt., 10c.

ESCHSCHOTTZIA, (CAITFORNIA POPPY). A hardy annual which is one of the most popular and beautiful flowers, it being very easily grown and gives great satisfaction. Pkt., $5 c$; oz., 35 c.

MANDARIN. Blossoms are copper-colored outside, and bright yellow inside. Pkt., 5c; oz., 35c.

CaIifornia DOUBIE. Pkt., $5 c$; Oz., $35 \mathrm{C}$

CARIMINCA. A new variety, rose cardinal. Pkt., 10c.

GRANDIFIORA ROSEA. Large flowers of rosy pink. Pkt., $5 \mathrm{c}$.

CARMIINE KING. Largest and best of the red varieties. Pkt., $5 \mathrm{c}$.

AIBA. New white variety. 5c.

EUPHORBIA MARGINATA, also called Snow on the Mountain. An annual of very showy appearance. Foliage is light green, broadly tipped with white. TVill grow in any soil, but must have sunny location. Pkt. $5 \mathrm{c}$

EVERIASTIVG FIOWERS. A mixture of all the varieties we have. Exceptionally good. Pkt., 5c.

EVINING GIORY OP GOOD NIGHT. The violet blossoms are fragrant and open at night. Pkt., $10 \mathrm{c}$ 


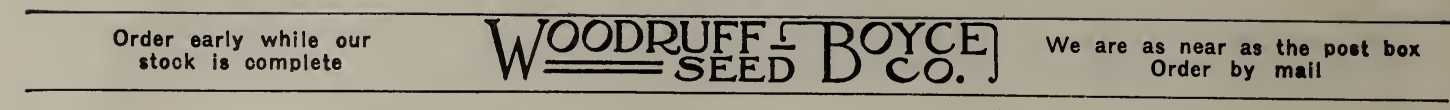

\section{FLOWER SEEDS-Continued}

FrvarFrw. Called double Feverfew. A plant growing 18 inches high, and bearing great numbers of pure white double flowers. Pkt., 5c.

FORGET-ME-NOTS. A favorite old-fashioned flower bearing in profusion, especially in the spring, great masses of dainty blue flowers. It thrives the best in moist, shady spots. One of the best perennials.

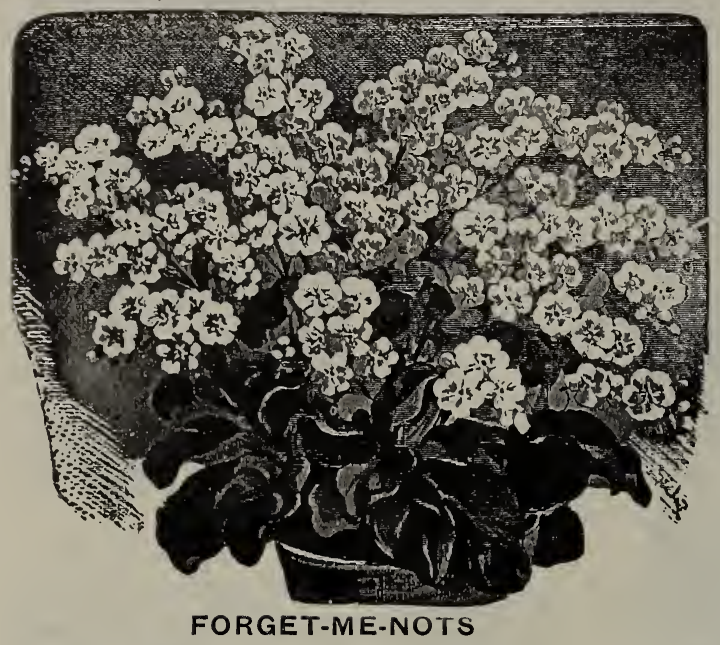

AIPESTRIA. A trailer, different blue stuans. Pkt., $10 \mathrm{c}$

SIIVATICA, Light blue shades. Pkt., 10c.

INDIGO BIUE. All dark blue shades. Pkt., $10 \mathrm{c}$.

RUTH FISCFrR. A new introduction. Very fine. Pkt., $15 \mathrm{c}$.

NFW COMPACTA. Very dwarf, a great bloomer. Pkt., $15 \mathrm{c}$.

HYBRIDIA ARGFNTTNA A new type of this old-fashioned flower lately introduced by the largest grower of flower seeds in Europe. They claim it is the finest. to be had. Light blue, compact flowers. Blooms from early Spring until Autumn. Pkt., $15 \mathrm{c}$.

rOUR O'CIOCK (Marvel of Peru). A hardy annual, about two feet high, of very easy culture. Flowers are purple and white. One of the oldfashioned favorites. Mixed colors. Pkt., $5 \mathrm{c}$.

Variegated and striped leaves, mixed. Pkt., 10c. FOX GIOVE. See Digitalis.

TRAGARIA. One of the best plants for hanging baskets and trailers. A perennial that can be grown very successfully in rock work. Plant in boxes and transplant. Pkt. of very choice seeds, $25 \mathrm{c}$.

FUCFSIA. See plants, which we have in season. GAIIIARDIA. A very pretty flower with brilliant scarlet and yellow blossoms. Blooms freely all the summer until late into the fall. A hardy annual. Single mixed, pkt., 10c; double mixed, pkt., $10 \mathrm{c}$.

GRANDIFIORA MAXIMA. A perennial variety, golden. Pkt., 10c.

IORENZIA, or DOUBIE FIOWHRING. Combination of yellows and reds. Pkt., $10 \mathrm{c}$.

FEICFRYSUM (Everlasting Flower). Is the best and most satisfactory of the everlasting flowers, and makes a beautiful bouquet of dried flowers. Mixed, pkt., $5 \mathrm{c}$ $10 \mathrm{c}$.

DOCTOR IIVINGSTON. A new variety. Pkt.
GIRANIUM. Comparatively few people are aware that Geraniums may be grown easily from seed and flower the first season if sown early. This is the best way to secure new varieties. Mixéd pkt., 10c. Lady Washington, pkt., $25 \mathrm{c}$.

GFUIM. A beautiful hardy perennial growing about 15 inches high and bearing many large, double flowers of brilliant scarlet from May to July. They are very attractive for cut flowers, as the stems are quite long. May be used for border plants. A splendid addition to the garden. Pkt., $10 \mathrm{c}$.

GIOXIIIA. One of the best hot house plants, with large bell-shaped flowers, which come in rich bright colors. Sow in the fall or early spring. Selected seed. Pkt., $25 \mathrm{c}$.

GODETIA. A hardy annual six to ten inches high. A heavy bloomer of satiny cup-shaped flowers in deep red, pink and white shades. A valuable plant for bedding. Sow seed early. Pkt., 5c.

TOM THUMB varieties or Dwarf Finest Mixed. Pkt., 5c.

IADY AIBERMARIE. Dark crimson. Pkt. $10 \mathrm{c}$.

PRINCESS FrNRY. Rose with large crimson blotches. Pkt., 10c.

DUCHESS OF AIBANY. Pure white. Pkt., 5c. AMAFNA. Rose color. Pkt., 5c.

GOMPFRENA (Globe Amaranth). Bushy plants about 2 feet high. The clover-shaped blossoms may be dried for winter bouquets. Mixed. Pkt., $5 \mathrm{c}$.

GOURDS. Our mixed seeds bear all shapes of this old-fashioned plant. Pkt.. 5c; oz., $25 \mathrm{c}$.

GOIDEN ROD. A hardy perennial, flowering late in the summer. Pkt., 5c.

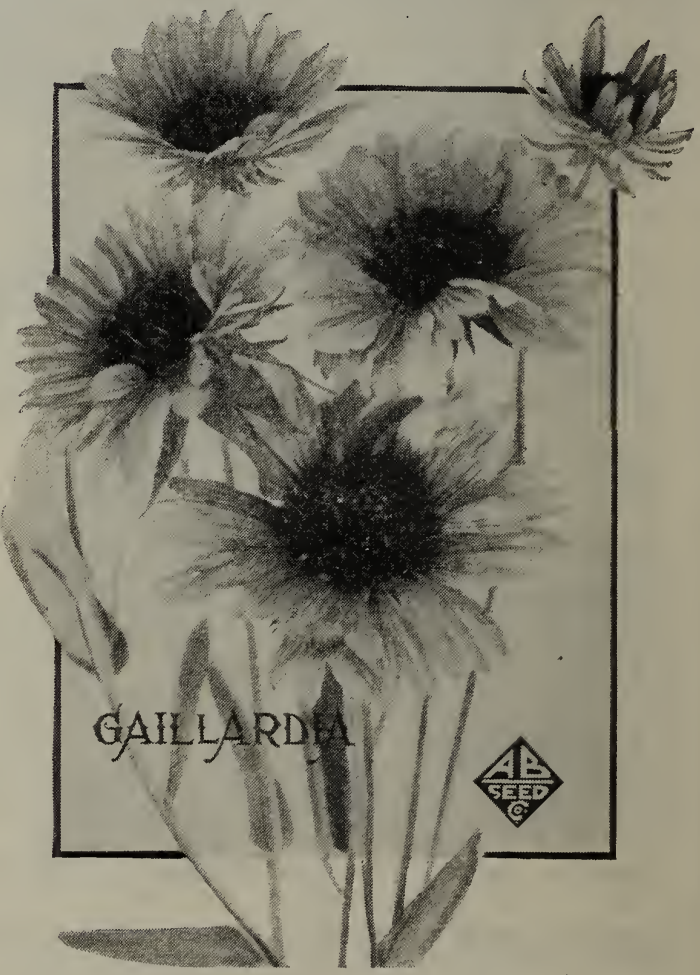


Do not trust to luck in buying seed-Ours are tested

\section{FLOWER SEEDS-Continued}

\section{GRASSES-ORNAMIENTAL}

ORNAMENTAI GRASSES. We list below the varieties that do the best in this locality. They are quite attractive and are of easy culture.

JAPANESE IAWN GRASS. Plit., $5 c$.

PAMPAS GRASS. Plit., $10 \mathrm{c}$.

FEATHER GRASS. Plit., $10 \mathrm{c}$.

GYPSOPHIIA (Eaby Breath). A fine feathery plant; very useful in making up Sweet Pea bouquets. A lover of Sweet Peas should plant Baby Breath.

MURAIIS. Pink flowers. Plkt, 5c.

PANICUIATA. White flowers; perennial. Pkt. Бc.

ELEGANS. White, best annual variety: Pkt., כc. PINK. Best pink variety. Pkt., 5c.

FAAGIANA HYBRIDS. Mixed colors. Usually grown as annuals; of diwarf, bushy habit, bearing flowers an inch or more across in continuous succession until frost, colors are particularly pleasing, white to rich scarlet and shades of pink;

1 foot. Plit., 10c.

HEIIANTHUS (Sunflower). Remarkable for the stately growth, size and brilliancy of their flower's, making a very good effect among shrubbery and for screens. Pkt., 5c.

HENDERSON NEW RED SUNFLרWER. A splendid garden annual, quick and robust in growth, very showy in the garden border or in groups or as hedges-and the long-stemmed flowers when cut and vased are most effective and last long in water. These gorgeous floral creations were bred by crossing various types of annual garden sunflowers witt. the only red sunflower in the world, so far as known, a small flowering hardy variety discovered by a botanist growing wild in Colorado. Among the artificial hybrids thus produced, remarkable new types of wonderful beauty and variety have developed. The plants commence flowering in about 8 weeks from seed sowing, and should stand not nearer than 3 feet apart for best development. Pkt., $15 \mathrm{c}$.

HEIIOTROPE. A half-hardy perennial, growing 2 to 4 feet high. A very fragrant small flower that can be raised from seed the first year. Does very well asainst a wall in a shady spot Finest mixed, pki., linc.

HELENIUM. A vigorous, hardy perennial that will grow in any soil. Blooms profusely in the late summer. Pkt., $10 \mathrm{c}$.

HESPERIS MATRONAIIS (Sweet Rocket). Stout, bushy plants 3 to 4 feet high with showy terminal spikes of flowers during June and July.

MATRONAIIS. Blue, Pkt., 5c.

AIBA. White. Pkt., 5c.

HIBISCUS (Mallow Tribe). Showy annual and perennial. Sow Africanus, the annual species, in early spring under glass, and plant out when all fear of frost has gone.

ArRICANUS. Annual. Creamy-yellow, purple markings. Pkt., $5 \mathrm{c}$

HOIIYHOCK. A hardy perennial of easy culture and a very satisfactory flower. Makes an excellent background and does well most any place you plant it. Can supply clumps of most any color. Double varieties, mixed. Pkt., $10 \mathrm{c}$.

BED, YELIOW, white, lavender, pink and salmon. Pkt., $10 \mathrm{c}$.

SINGIE VARIETIES. Mixed colors. Pkt., 10c. SINGIE WHITE. Pkt., 10c.

HUMUIUS (Japanese Hop). One of the very best climbing annuals we have. Fine for covering porches, fences, etc. WVill grow 20 to 30 feet in a season. Pkt., $5 \mathrm{c}$.
HUNNEMANNIA FUMARIAEFOIIA (Yellom Tulip Poppy). The foliage is like that of Eschscholtzia, the flowers like the tulip "Bouton d'or" in size, color and form, the height 2 feet; the flowering season September and October; the sowing season May 15 in the garden or border. Have you ever grown it? If not, you surely will find it a most delightful garden occupant when other flowers have said farewell; and what splendid cutting material it makes. The large flowers, carried on stout stems, last several days in water. Plit.. $10 \mathrm{c}$

ICE PIANT. A low growing tender annual. Fine for vases and rock work. Thrives in bright, dry spots. Pkt.. $5 \mathrm{c}$.

IMPATIENS HOISTII. Charming plants for the decoration of the house or the dinner table, producing bright, waxy flowers profusely and continuously. Pkt., $25 \mathrm{c}$.

INCARVIIIEA (Delavayi). Beautiful new garden plant with long, flexible branches, It forms large fleshy roots the first year, which should remain in the ground the next season, and thereafter they throw up strong flower stalks 3 feet high, bearing large tubular flowers of rosycarmine, spotted yellow; throat, brown. Pkt., $15 \mathrm{c}$. IPOMOEA. A most satisfactory annual climber. Best Imported strains.

COCCINEA Or STAR IPOMOEA. Small scarlet blossoms. Vines about 10 feet. Pkt., $10 \mathrm{c}$

KAUIFUSSIA (Amelloides). The whole effect of this plant is a medium sized intense blue daisy: fine for bedding; is clear, even, light blue in color; 10 inches high, $1 \frac{1}{4}$ inches across; annual. Pkt., $10 \mathrm{c}$.

KOCHIA (Summer Cypress). A splendid ornamental plant forming dense oval brushes, 1 to 2 feet high. Light green foliage, and as summer advances this changes to carmine and then fiery

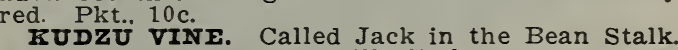
A hardy perennial that will climb as much as 40 feet in a season. First year grows 10 feet. Fine for a nermanent vine. Pkt. 10c.

\section{HOLLYHOCKS}

EVER-
BLOOMING
ANNUAL

A comparatively new class, flowering from seed as early as almost any of the garden annuals. They require good care and rich soil, but will abundantly repay a little extra effort.

Mixed pkt., $15 \mathrm{c}$.

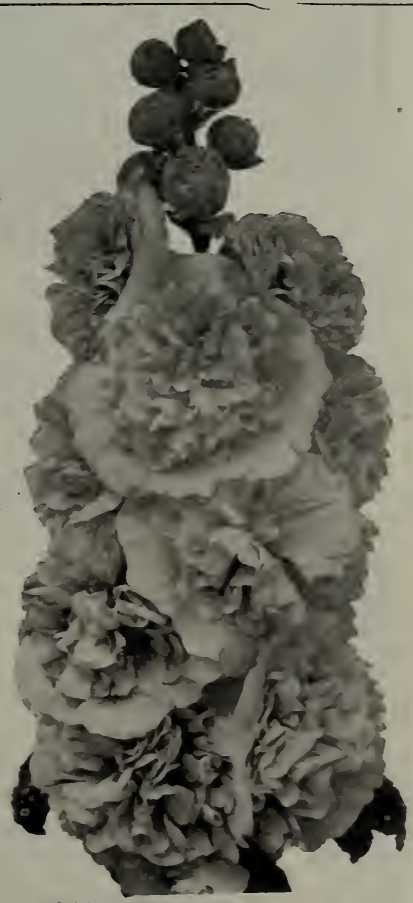

DOUBLE HOLLY HOCKS 


\section{FLOWER SEEDS-Continued}

IANTANA. A tender perennial. Can be used as a hedge and bears a very pretty flower in clusters. Blooms all summer. Finest mixed. Pkt. $10 \mathrm{c}$.

\section{LARKSPUR}

There are two distinct varieties of this, the annual and perennial. The annual grows from $11 / 2$ to 2 feet high. A great variety of colors and does well in any soil. Very easy culture, dwarf rocket, double mixed. Pkt., $5 \mathrm{c}$.

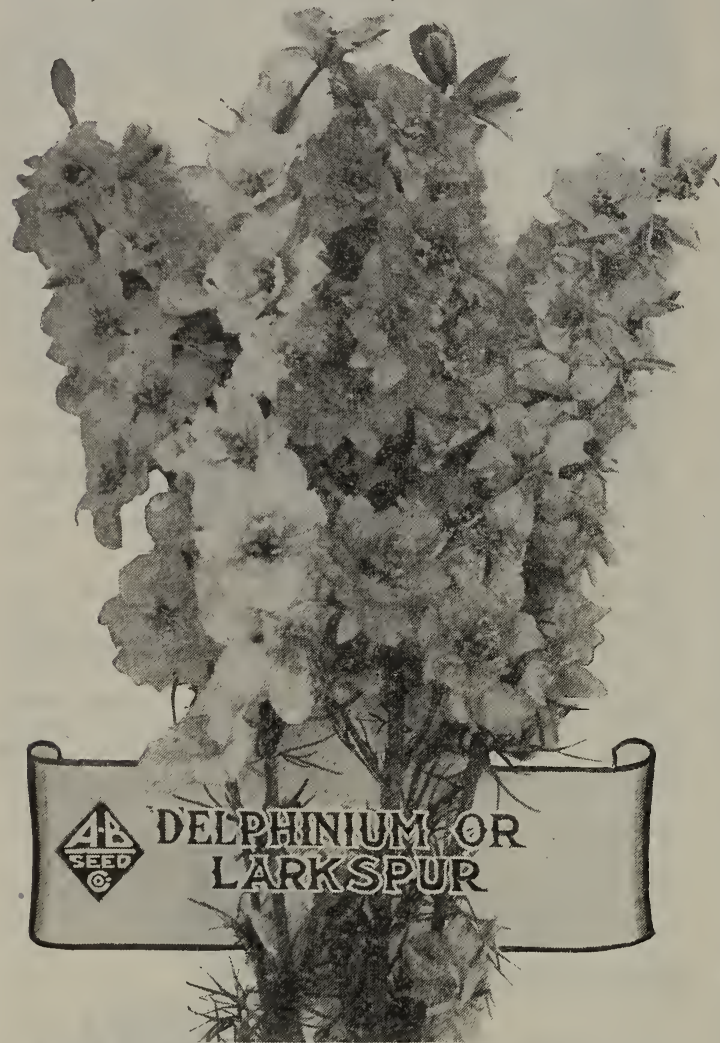

EMPEROR. A branching variety that does excellent. Double. Pkt., 10c. Rose and white, separate colors. Pkt., $10 \mathrm{c}$.

GIANT FYACINTH-FIOWERED IARKSPUR.

This is the finest of the improved Larkspurs. The splendid flowers are very large and very double, and the colors beautiful. Height 15 to 18 inches. WHITE. Pkt., 10c.

ROSE. Pkt., 10c

INDIGO BIUUE. Pkt., $10 \mathrm{c}$

DWART HYACINTH-FIOWERED IARKSPUR.

The same strain as the GIANT, but of dwarf habit.

IIGHT BIUE. Pkt., 10c.

ROSE. Pkt., 10c

BRICK RED. Pkt., 10c.

WIITE. Pkt., $10 \mathrm{c}$.

CARDINAIE. A scarlet that cannot be beat.

Pkt., $10 \mathrm{c}$.

Chringse AzUrium. Single blue. Pkt., 10c.

FIATUM BIUE. Various shades, dark centers. Pkt., 10c.

FORMOSUM. Beautiful spikes of rich blue

flowers with a white center. Pkt., 10c.

COrmastrivum. Exquisite celestial blue and white centers. Pkt., $10 \mathrm{c}$.

HYBRIDUM BEIIA DONNA FANNY STARMONTH. The finest of all the perennial Larkspurs. Grows 5 to 7 feet high, the last 2 to 3 feet forming a huge, branching raceme of well placed flowers of exquisite azure blue. Pkt., 10c.
IOBEIIA. A hardy annual and perennial. The annual grows 4 to 6 inches high, very compact and fairly covered with tiny blue flowers. They are especially used for borders and in hanging baskets.

CRYSTAI PAIACE COMPACTA. This variety is mostly used for borders. Pkt., $10 \mathrm{c}$.

GRACIIIS. Light blue. A trailing variety especially used for hanging baskets. Pkt., $10 \mathrm{c}$. $10 \mathrm{c}$.

CARDINAIIS. Has spikes of cardinal flowers. Pkt., 10c.

IEPTOSIPASION. A dwarf plant excellent for borders and rock work, bearing small clusters of bright, attractive flowers. Pkt., $5 \mathrm{c}$.

TEMON VERBENA (Aloysia Citsiodora). A great favorite is this old perennial for the delightful fragrance of its leaves. Grows easily from seed. The foliage combines well with any flower. Pkt., $10 \mathrm{c}$.

IINARIA. A charming perennial of low habit and easy culture; the flowers are mostly violet and light purple, with a white lip, yellow blotched. Sow in spring. Pkt., $10 \mathrm{c}$.

IINUM (Scarlet Flax). A hardy annual about $11 / 2$ feet high. An attractive plant with bright red flowers on tall, slender stems, which are borne in profusion. Sow early in spring where plants are to grow.

IYCHINIS (Chalcedonica). The scarlet Lychnis, an old garden favorite, bearing heads of bright scarlet flowers; very hardy; 3 to 4 feet. Pkt., 5c.

IUTrA. Vine grows to medium size and bears small yellow flowers. Pkt., 10c.

IUPINUS, or IUPINS. A hardy annual, native to California. Grows 2 to 3 feet high, and bears spikes of pea-shaped flowers. Of the easiest culture.

CRUIKSHANKII. Double blue. Pkt., 5c.

PINK. Long spikes of bright pink flowers. Pkt., 5c.

POIYPHYIIUS. Tall, handsome white flowers. Pkt., 5c.

MARVEI OF PERU, OP FOUR O'CIOCK (MITAbillis Jalapa). A well known, handsome, freeflowering garden favorite; does well everywhere; give each plant 12 to 18 inches of room. Fine mixed colors, 2 feet. Pkt., 5c; 0z., $20 \mathrm{c}$.

IMARIGOID. A hardy annual. One of the best and easiest growing flowers we have. It is oldfashioned and loved by all.

FIDORADO, called the African Marigold. The best tall variety, bears large double flowers. Pkt. $5 \mathrm{c}$.

MIXED AFRICAN. Pkt., 5c.

TAII YEIIOW AND ORANGE. Pkt., 10c.

DWART IRENCH. Small flowers, double. Pkt., $5 c$.

TAII FRENCH. A mixture of tall double varieties. Pkt., 5c.

POT MARIGOID. See Calendula.

MATTHIOIA, Evening scented stock. They are exceedingly fragrant in the evening, scenting the surrounding atmosphere. Purple flowers. Sturdy annual. Pkt., $5 \mathrm{c}$.

MATRICARIA (Capensis Alba Plena). Double White Feverfew. Free-flowering plants, protucing all season fine double white flowers. A fine bedding or pot plant; 18 inches. Pkt., 10c.

MESEMBRYANTHEMUM (Ice Plant; Crystallinum). A low-growing and trailing tender perennial. The thick leaves seem to be covered with crystals. Used for edging embankments and box work; thrives in bright, sunlight and in dry situations. Flowers, cerise purple and small, completely covering plant. Pkt., 10c. 
You will derive pleasure, health and
profit from a Vegetable Garden

\section{FLOWER SEEDS-Continued}

MaUIUS, Showy, profuse-flowering plants fne for greenhouse or moist, shady situations: half-hardy perennials, blooming the first year from seed if sown early; 1 foot. Pkt., $10 \mathrm{c}$.

MOON FIOWER (Grandiflora Alba). Wiil grow $50 \mathrm{ft}$. in a season. Is literally covered with large white flagrant flowers which expand at night and in the early morning. Plit., $10 \mathrm{c}$.

MORNING GIORY. One of the oldest and most favorite flowers. The seeds we are offering are of improved type and give good results.

TAII, or CIIMBING VARIFTIES. Mixed, pink, white and blue.,. Pkt., $5 \mathrm{c}$.

IMPERIAI JAPANESE. Flowers are larger than most of them, but not as good a climber. Plit., $10 \mathrm{c}$.

DWARF, or BUSH VARIETY. Useful for beds, edging, or in hanging baskets. Pkt., $5 \mathrm{c}$.

MIGNONETTE. A half-hardy annual that is known by every one, and is planted for its fragrant flowers, which come thickly. Set on compact spikes.

GOIDIN MACHFT. A compact glowing variety with medium long thick spikes of yellow flowers. Plt., 5c; oz., $50 \mathrm{c}$.

PARSON'S WHITE. A tall variety with silvery flowers. Pkt., 5c; oz., $50 \mathrm{c}$.

RUBY IACHET. A compact variety bearing coppery flowers. Pkt., $10 \mathrm{c}$.

GRANDIFIORA. An exceedingly large flowering type. Pkt., $10 \mathrm{c}$.

BISMARK. A fine improvement over the older types; very strong grower, with large, reddishtinted flowers. Pkt., $10 \mathrm{c}$.

GOIIATH. Finest of all, giant trusses of brilliant red. This is fine to mix in with the less expensive sorts. Pkt., 25c.

MINA. A beautiful and rapid-growing climber, producing innumerable brilliant blood red flowers. $1 / 4$ oz., $15 \mathrm{c}$

MEXICANA AIBA (Mexican Morning Glory). Flowers white. Pkt., $10 \mathrm{c}$.

MUSA ENSFTE (Abyssinian Banana). Splendid tropical plant; may be set outdoors in summer. 10 seeds, $20 \mathrm{c}$.

MUSK PIANT. A half-hardy perennial. Very useful for window gardens; thrives best in damp shady spots, and blooms the first year from seed. Very fragrant. Plit., $5 \mathrm{c}$.

\section{NASTURTIUMS}

A tender annual in two classes. Dwarf and Tall, or climbing. A great favorite that does exceedingly well in any location. Prefer a dry, poor soil, as the plants have more flowers than when planted in rich soil.

TALL OR CLIMBING NASTURTIUMS

Grow six to ten feet high and bloom profusely during summer and fall.

CHAMAEIEON. Varied colored blooms.

KING THEODORE. Very dark crimson.

PEARI. Cream-white or crimson.

VESUVIUS. Salmon-rose.

Any of the abore: Pkt., $5 \mathrm{c}$; oz., $15 \mathrm{c}$.

FAII IVY IEAVED. Pkt., 10c; oz., 20c.

\section{LOBB'S CLIMBING NASTURTIUMS}

ASA GRAY. Pale primrose-yellow.

BRIILIANT. Intense scarlet-red.

BACK PRINCE. Purplish-crimson.

GOIDEN QUEEN. Bright golden-orange. GIANT OF BATTIES. Yellow, splashed with red.

KING OF THE BLACKS. Dark red.

SPITFIRE. Fiery scarlet.

Any of the above, pkt., $5 \mathrm{c}$; oz., $20 \mathrm{c}$.
DWARF OR BEDDING NASTURTIUMS

CRYSTAI PAIACE GEM. Yellow spotted with

carmine.

DWARF KING THEODORE. Crimson-maroon.

DWART PEARI. Cream-white.

DWARF CHAMELEON. Variety of colors.

DWART VESUVIUS. Deep salmon-rose.

EMIPRESS OF INDIA. Fiery crimson.

PRINCE HENRY. Light yellow suffused with scarlet.

Any of the above, pkt., 5c: oz., $15 \mathrm{c}$.
OUEEN OF TOM THUMBS. Pkt., 10c; oz., $20 \mathrm{c}$

QUEEN OF TOM THUMBS. Pkt., 10c; Oz.,

TAII MIXED. Pkt., 10c: oz., $20 \mathrm{c}$

DWARF IMIEED. Pht., $10 \mathrm{c} ; 0 \mathrm{z}$, $20 \mathrm{c}$

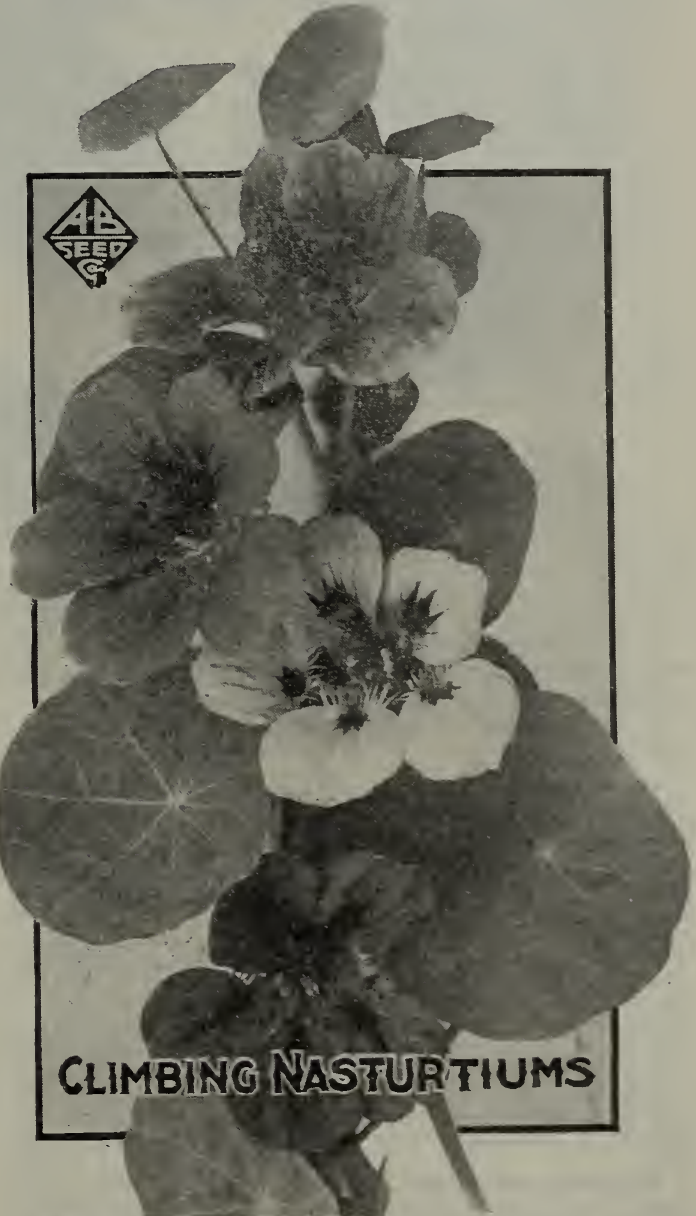

NEMOPHILA (IOVe Grass). A hardy annual growing about six inches high. Has small cupshaped blossoms in white and blue shades. Pkt., $5 \mathrm{c}$.

NIGEIIA (LOVe-in-a-Mist). A hardy annual, small flowers. Curiously shaped blossoms and seed pods. Very easily grown. Pkt., 5c.

NICOTINA, or FIOWERING TOBACCO. A hardy annual, growing about three feet high. Belongs to the tobacco family. White and very fragrant. Flowers open in evening and cloudy days. Pkt., 5c

OKAIIS. A half hardy perennial. Flowers bright colored and very attractive. Suitable for rock work and edgings. Pkt., $10 \mathrm{c}$. 


We want your trade
Wo'll surely please you

\section{FLOWER SEEDS-Continued}

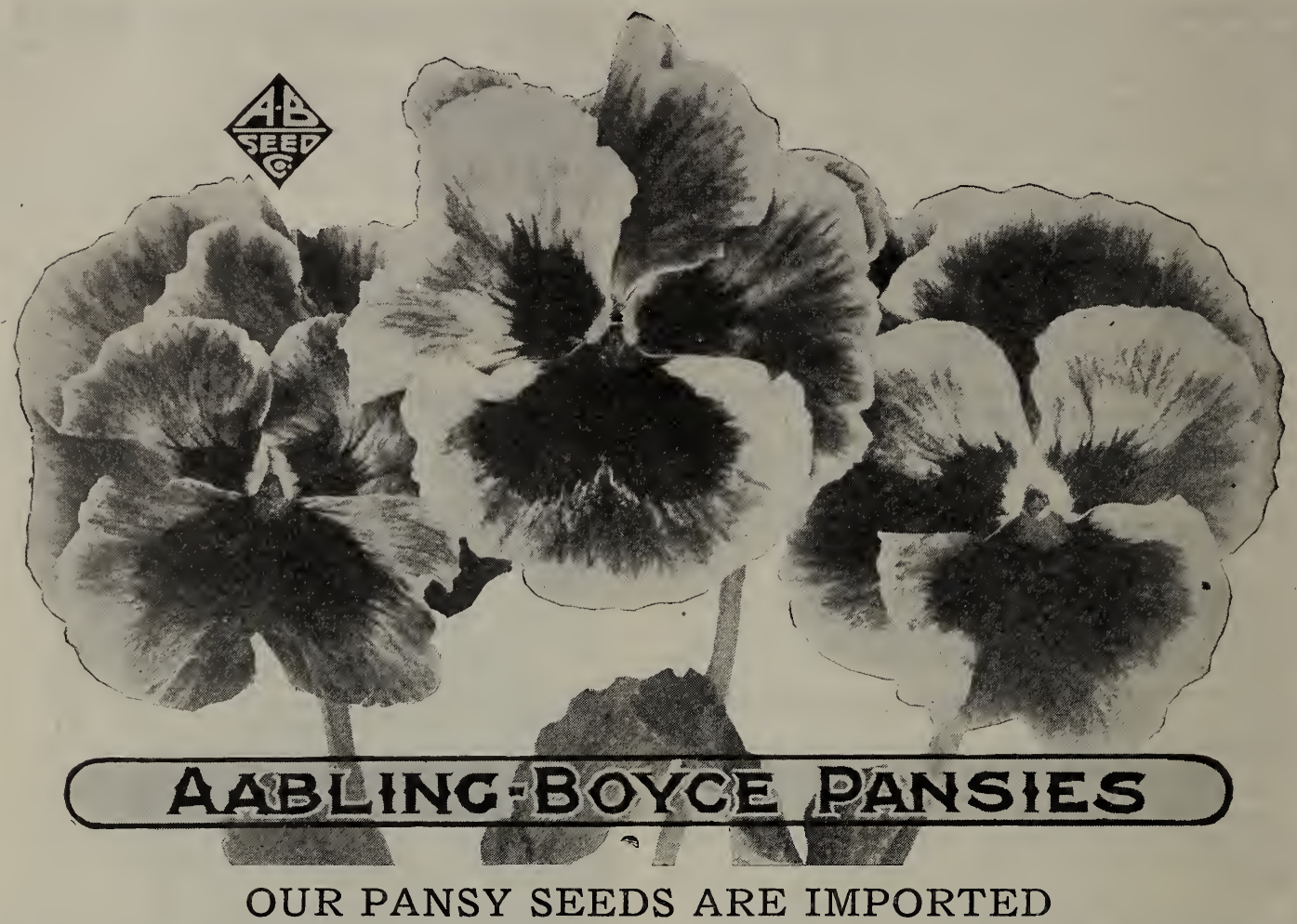

We import our pansy seeds direct from the leading growers in Europe, and in that way we are assured that we have seeds that have passed the experimental stage and are bound to give you fine flowers.

For outdoor bedding seeds should be sown in boxes very early and covered with glass, then transplanted.

PANSIES are favorites with all, but for best results you must start with the good strains.

PANSY SFFD germinates and the plants grow more freely in the cool, early days of spring, and for summer blooming should be sown by the later part of April, or early May. A soil containing a portion of leaf mould, well enriched with welldecayed cow manure, will be the most satisfactory for the growing of this flower, and it should be well dug and made fine and level.

ORCHID FIOWERITG. A mixture of delicate shades and pleasing light tones. Flowers light shades and entirely new. Pkt., 20c.

TRIMARDEAU. The largest flowering type of pansies; called the French strain. The petals are different sizes and very beautifully marked. Pkt., $15 \mathrm{c}$.

BUGNOT SUPFRB. A round ruffled five-petal type, with soft blended colors and tints, veined on the margin, and a dark blotch at the base of each petal. One of the finest varieties. Pkt., 25c.

IARGE FIOWERING MIXED. A mixture of practically all the varieties, shades and tints, with the exception of the rarest ones. Pkt., 10c.

FINE MIXED COMMON VARIETIES. Pkt., $15 \mathrm{c}$.

NAMED VARIPTIES. In separate colors. These are an extra good quality of the straight colors for those who like a bed of one shade. Any color. Pkt., $10 \mathrm{c}$.

MASTrRPIFCE PANSY. What is prettier and gives more pleasure than a bed of pansies? Packet contains enough seed to be assured of 100 plants. Sold only in $25 \mathrm{c}$ packets. Try one.

Our stock of Pansy seed, especially of this variety, is the finest to be had in all of Europe.

Page 52

The flowers have been known to measure up to 4 inches across and invariably run between 2 and 3 inches. Healthy, robust plants producing flowers on extra long stems, which have elegantly waved or curled petals, giving the flower a distinctly refined appcarance. The seed comes in mixed colors, with a greater portion of the blotched varieties. There is no finer quality of pansies in existence than we are offering and we defy competition. Pansies delight in semi-shaded, cool locations, and they must be kept supplied with moisture during the hot months of the year.

\section{DIPPE'S SELECTED STOCK}

We have secured a selected strain of this choice flower, which bears fully $80 \%$ of double flowers. They bloom very early.. A beautiful soft pink, long stems. Fine for cut flowers. Pkt., 15c. TUFTED PANSIES OR VIOLAS

Few people appreciate the beauty of these flowers but no one who has once seen a bed or border of them can faii to realize how much they add to a garden.

They are especially adapted to shady places and are invaluable for edging flower beds or walks.

While not so large as the other pansies, they bloom much more freely and possess a wonderfu color effect. We have them in a variety of colors. Pkt., $10 \mathrm{c}$.

PFiTsTrmor. Similar to the Fox Glove, but in a greater variety of colors. It is a hardy perennial and blooms the first year from seed Basily grown, decidedly beautiful, and very saticfactory. Mixed, pkt., $10 \mathrm{c}$. 


\section{FLOWER SEEDS - Continued}

\section{PETUNIAS}

PETUNIAs. They grow with very little care in any soil and bloom all spring and summer. The seed should be sowed carefully and just pressed into the ground, and covered with moss or sand.

SINGIF. Deep throated, brilliantly blotched.

Pkt., 25c

DOUBIE. White blotched, brilliantly colored. Pkt., 25c

FINE MIXED. Good mixture of small varieties. kt., $10 \mathrm{c}$

HOWARD'S STAR. A most attractive Crimson Maroon Petunia with clearly defined five-pointed star of blush white. Exceptionally fine. Free flowering. Pkt., $10 \mathrm{c}$.

NORMA. Of dense, bushy habit about 8 inches high. Flowers not so large, but so profuse as to entirely cover the plant. A velvety blue with white center. Unexcelled for bedding. Pkt., 10c.

COUNTESS OF ELISMrRE. Rose with white throat. Splendid bedding variety, flowers very freely. Pkt., 10c.

FIMBRIATA. The finest single strain, bearing Immense flowers, sometimes 5 inches in diameter. Edges beautifully ruffled and fringed. The colorings are truly wonderful.

IIGHT YEIIOW. Pkt., 10c.

BRIIIIANT ROSE. Pkt., 10c.

MIRANDA. Rosy red with scarlet throat. Pkt. $10 \mathrm{c}$

CHOICEST MXED. Pkt., 10c.

\section{PHLOX}

CUITURE. Sow out of doors when all danger of frost is over, in the bed where they are to flower. Cover to a depth of about $1 / 2$ inch and press the earth down firmly. Thin out so that plants will not be crowded.

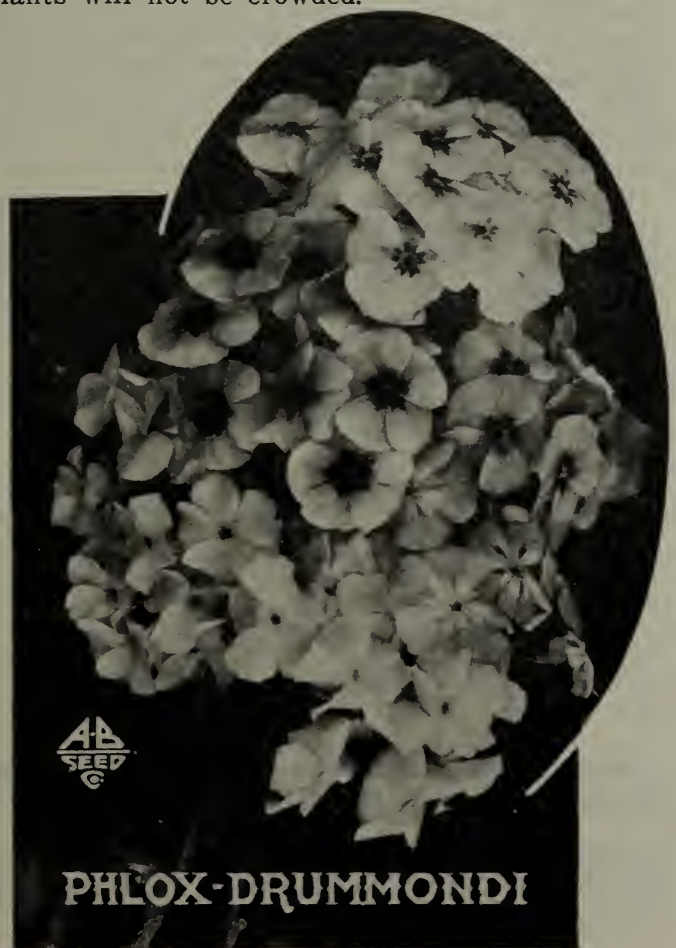

PHIOX (Drummondii). A harãy annual growing from six inches to one foot high, and bearing rich and beautiful colored flowers. It is of very easy culture and a great favorite. Pure white, brilliant rose, brilliant scarlet, and mixed. Pkt., $10 \mathrm{c}$.

STAR PHIOX (Cuspidata). Flowers have a distinctive star-like appearance, with colored eye. Pure white, pink, and mixed. Pkt., $10 \mathrm{c}$.

PHIOX (Decussata). Hardy perennial, mixed. Pkt., 10c.

DWARF PHIOX. This variety grows only six or eight inches high but bears flowers nearly is large as the taller varieties. Pkt., 10c.

\section{POPPIES}

Annual Poppies should be sown as early in the spring as possible where they are to remain, as they do not stand transplanting. Sow very thinly, preferably in cloudy weather or after a shower, barely cover the seed, press down firmly, and they will come up in a few days. If they come up too thickly they must be thinned out to stand 3 to 4 inches or more apart if you wish best results. It is well to make several sowings at intervals to keep up a succession of bloom. If picked just before expanding the flowers will last several days. It is also advisable to pick the old flowers as soon as fallen, which will lengthen the blooming season quite awhile.

\section{SINGLE ANNUAL POPPIES}

ADMIRAI. A single peony-flowered variety of surpassing beauty, having large, smooth-edged flowers of glistening white, with a broad band of brilliant scarlet around the top. These two colors form a striking contrast, and when planted in groups produce a magnificent effect. Plit., $10 \mathrm{c}$.

BIACK PRINCE. A beautiful single Poppy of brilliant blackish brown color with a violet hue, contrasting wonderfully with the whitish stamens. Pkt., $10 \mathrm{c}$.

SHIRIEY. This is an extra fine strain of these charming Poppies. They are single and occasionally semi-double, and range in color from the purest white through the delicate shades of pale pink, rose and carmine to the deepest crimson and blood-red, while many are daintily edged and striped. In fact, so varied are they that scarcely any two flowers are exactly alike. Pkt., 5c.

DANEBROG, or DANISH COAST. Very showy variety, producing large flowers of brilliant scarlet, with a silvery-white spot in each petal, forming a white cross. Pkt., $5 \mathrm{c}$.

TUIIP FIOWIRED. One of the most brilliant; the flowers are 3 inches across and closely resemble the brilliant Scarlet Gesneriana Tulip. Pkt., 5c.

\section{DOUBLE ANNUAL POPPIES}

MrKaDO (the Striped Japanese Poppy). This beautiful Poppy is very distinct in character and color. The flowers are brilliant scarlet and white, with elegantly curved petals, like a Japanese Chrysanthemum. Pkt., 15c.

RANUrCUIUS. Something decidedly new in the double flowering Poppy and one that will become a great favorite as soon as it becomes generally known. If you want the best, try a package of this. Pkt., 15c.

DOUBIF CARNATION. A very beautiful type in rich, effective shades. Mixed colors. Pkt., $5 \mathrm{c}$. 
Do not trust to luck in ordering seeds-Ours are tested

\section{FLOWER SEEDS - Continued}

\section{HARDY PERENNIAL POPPIES}

Oriental Poppies should be sown in early spring in the open ground as soon as it is fit to work. The plants disappear during July or August, appearing again as soon as the weather gets cool. When the fall growth starts is the time they ghould be transplanted to their permanent flowering quarters. It is well to mark the places they are planted with a stake to insure the roots against disturbance during their annual resting period.

Among hardy perennials these hold an unrivaled position for gorgeous effectiveness in gardens and hardy borders; height, 2 to 3 feet; flowers immense, often 6 inches or more across. They are also grand, cut in bud state, for vases.

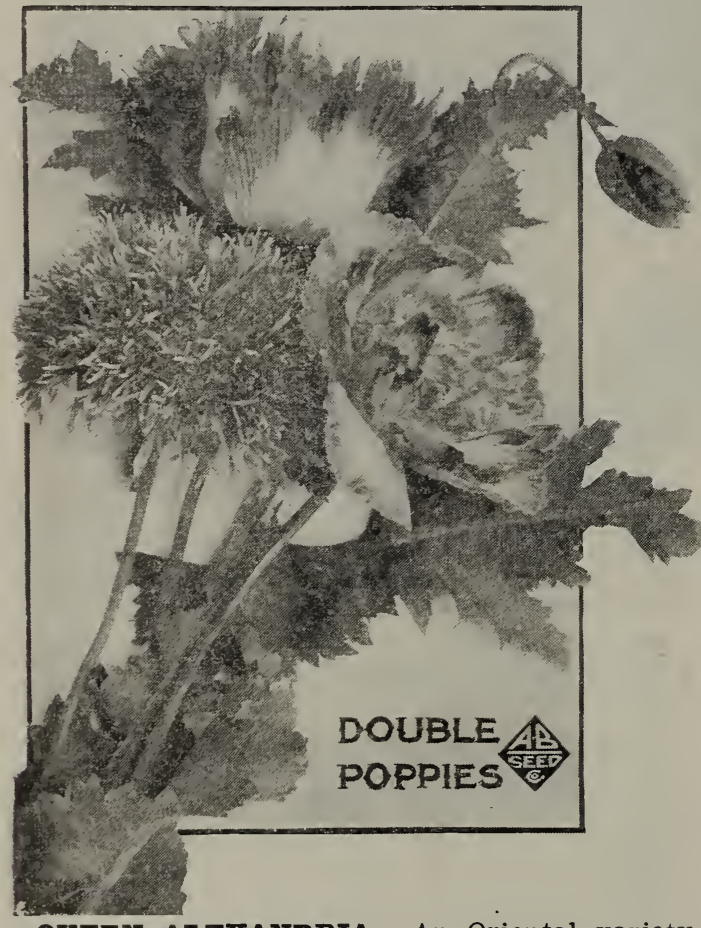

QUEFN AIFXANDRIA. An Oriental variety, barge, brilliant crimson flowers, with a black blotch on each petal. Very showy and attractive. Pkt., $25 \mathrm{c}$.

ROYAI SCARIET. One of the rarest and most exquisite flowers we have. The flowers are immense in size. Pkt., 25c.

PRINCESS VICTORIA IOUISI. One of the choicest perennial Poppies. It grows to a height of 3 feet and is an exquisite delicate salmon color. Splendid for cutting. Pkt., $10 \mathrm{c}$.

ORIFNTAI. A choice mixed collection of the best Oriental Hybrids. It includes all the best named varieties. Pkt., $10 \mathrm{c}$.

\section{ICELAND POPPIES \\ (Papaver Nudicaulo)}

Although hardy perennials, these dwarf Poppies bloom the first season from spring-sown seed. The fragrant, elegant, crushed satin-like flowers are produced in never-ceasing succession from the beginning of June to October; fine for cutting. Pkt., 10c.

\section{CALIFORNIA POPPY}

FSEHSCHOITZIA (See page 48). Pkt.,.5c; ROMNEYA (California Tree or Matilija Poppy). This beautiful Poppy, while hardy, should be planted in a well-drained, sunny, sheltered position. It grows 3 to 5 feet high, and frequently has from 12 to 15 expanded flowers on a single shoot at one time. The flowers are white, 6 inches and over across, delicate and transparent. yet enduring in a good state for several tays: delightfully fragrant. Pkt., $10 \mathrm{c}$.

\section{PRIMROSE}

OBCONICA GRANDIFIORA. These "Ever flowering Primroses" are favorite pot plants for house and conservatory. The Chinese Primroses will have to look to their laurels, for this new giant Obconica race is looming up in size of flowers, many of them measuring $1 \frac{1 / 2}{\text { inches }}$ across, equalling in dimensions those of their Chinese rivals, with the added merit of being easier grown and having a longer duration of bloom. Several colors in mixture, white, crimson, rose, violet, lilac, pink-eyed sorts, etc. Pkt., $25 \mathrm{c}$.

PRIMUIA (Primrose). The charming and beautiful Chinese Fringed Primroses and Obconica varieties are indispensable for winter or spring decorations in the home or conservatory. They are one of the most important winter blooming pot plants. The seed we offer is of the highest merit and has, as usual, been saved from the best strains of English and continental growth. Florists and others report that they have never seen finer flowers than those produced from our seed. Sown in March, April or Mav. The hardy varieties are also deserving of wide circulation.

SINENSIS (Chinese Fringed). Chinese Primroses are among our finest winter and spring blooming pot plants; of healthy, sturdy growth, 8 to 12 inches high, and free from insects. They produce for weeks large trusses of flowers, which in our new Giant varieties, average from $4 \frac{1 / 2}{2}$ to 6 inches in circumference. Giant, double, mixed, colors. Pkt., $50 \mathrm{c}$.

PUERARIA THUNBERGIANA (Japanese Kudzu). To this must be awarded first place as the fastest growing hardy climbing plant. It will grow 8 to 10 feet the first year from seed, and after it has become established there seems to be no limit to its growth, 50 feet in a single season not being unusual. Its foliage is large and covers well; it bears small racemes of rosy-purple; pea-shaped blossoms towards the close of August. A splendid subject for covering pergolas and unsightly verandas, dead trees, etc. Pkt., $10 \mathrm{c}$.

PYRETHUM. A hardy perennial with bright foliage. Used for edging and borders. Seed can be sown in spring and transplanted. Mixed. Pkt., 5c. Grandiflora type. A larger type of flowers, some of which measure four inches across, and vary from light pink to deep carmine with deep centers. Mixed. Pkt., 10c.

RHODANTHE (Swan River Fverlasting). A charming annual; succeeds in a light rich soil and a warm, sheltered situation; valuable for pot culture; flowers everlasting; mixed colors; pkt., $10 \mathrm{c}$

RUDBFCKIA (Cone Flower). A free flowering annual that is a very effective cut flower. Easily grown. Mixed colors. Pkt., 5c.

SAIPIGIOSIS. A half hardy annual, growing about three feet high and bearing trumpet-shaped flowers of rich shades and colors, all beautifully veined, finest mixed. Pkt., $5 \mathrm{c}$. 


\section{FLOWER SEEDS -Continued}

SAIVIA or FIOWFRING SAGE. A tender perennial, blooming the first year from seed. The blossoms are borne on long stems and are very fragrant. Blooms last all summer. Patens, bright blue flower, two feet tall. Pkt., $25 \mathrm{c}$. Splendens, bright scarlet flower. Pkt., 10c.

SAPONARIA (Bouncing Bet). A perennial, especially good for rock work. Pkt., 5c.

SCABIOSA (Morning Bride). An annual that is worthy of a place in every garden. The tall flowers are especially adapted for cutting and massing in the garden. These new flowers are double clear to the center. Of very easy culture. Rose, white, scarlet and purple. Pkt., 10c. Mixed, pkt., $5 \mathrm{c}$.

SCARIET RUNMER. A flowering bean that can be used for food; will grow 30 feet in a season. Pkt., $10 \mathrm{c}$.

SCHIZANTHUS. Hardy annuals, growing one and one-half to two feet high, bearing bright, showy butterfly-like blossoms. Large flowering. Mixed, pkt., $10 \mathrm{c}$.

SEDUM. A little annual bedding plant, good for carpet work. Blue flowers. Pkt., 10c.

SENECIO (Tall Double Jacobea). A showy, free-flowering hardy annual. It produces, in great profusion, branching spikes of Cineraria-like double flowers, one and one-half inches in diameter, from spring until fall. Excellent for. bouquets. Elegans, double mixed, pkt., $10 \mathrm{c}$.

SIIFNe (Pendula Compacta, Double). An effective garden annual forming compact, round bushes, 6 inches high, which, during the summer are covered densely with flowers of white, pink or red. For low beds or edgings it is very pretty. Mixed colors. Pkt., $5 \mathrm{c}$.

SMIIAX. A climbing perennial, with beautiful bright-green glossy leaves. Largely used for decorating. Start seeds under glass and transplant. Pkt., 5c.

SNAPDRAGON (Antirrhinum). A half hardy perennial, growing from one and one-half to two feet. Flowers are oddly shaped. They are borne on long spikes; fine for cutting and keeping fresh a long time. Very easily raised. Tall flowering type in scarlet, white, pink, yellow and mixed. Pkt., 10c. Tom Thumb, or dwarf, mixture, pkt. $10 \mathrm{c}$.

SOIANOM (Capsicastrum, Jerusalem Cherry). This is a very useful pot plant for winter decoration. It is of dwarf branching habit, leaves small and oval-shaped, bearing in the greatest profusion bright scarlet globular berries. Very ornamental 1 foot. Pkt., 5 c.

STATICE SINUATA (Sea Iavender). A blue everlasting flower used by florists for winter bouquets. An annual that blooms late. Pkt., 5c.

STrviA. A tender perennial, 11/ feet high, and bearing clusters of small, white, fragrant blossoms. Suitable for summer or winter bloom ing, and for pot culture or open air. Serrata. Pkt., 10c.

STOKESIA (Cyanea, the hardy Corn Flower Aster). This is not new, but is a rare and beautiful hardy perennial. The plant grows about 24 inches high, each bearing from 20 to 30 handsome lavender-blue cornflower-like blossoms; in bloom from July till frost. One of the choicest subjects for the hardy border and indispensable for cutting. Pkt., $10 \mathrm{c}$

SWIET WIIIIAM. One of the finest old fashioned perennials. Makes a beautiful beddin plant, and is of very easy culture. Single and double varieties; mixed colors. Pkt., $5 \mathrm{c}$.

SWIFT SUITAN. A Centaurea of well known merits that makes a fine bedding plant, and an excellent one for cutting. Blossoms in white, yellow, red, lavender, purple and mixed. Pkt., $5 \mathrm{c}$.

SWrFT ROCKET. See Hesperis Matronalis.

\section{STOCKS-GILLIFLOWER, DOUBLE, TEN WEEKS}

Fragrance instantly draws the flower lover to any and all species of plants, and when the plant has other attractive features it is sure to be a favorite among gardeners. This certainly holds good of the gilliflower, which is not only possessed of a delightful perfume, but is a most showy garden plant. The newer improved types certainly have given this plant more grice and value as a cut-flower, as they will keep on blooming perpetually during the entire summer Wo offer but two strains, as they embody the best features of all. We are offering some exquisite shades. Our seeds can be relied upon to produce a large percentage of double flowering plants. All our strains are of free branching habits, ing 18 inches to 2 feet high, and producing very large double flowers, which encircle the stout flower-stems to a length of 12 or more inches.

WOODRUIF, DWARI GIA I T FIOWIRITG TI IT W $\mathbf{E} \mathbf{K} \mathbf{S}$. Selected
seed, in crimson, lav
ender, white, yellow, ender, white, yellow, pink, carmine, purple, red and mixed. Pkt. $10 \mathrm{c}$

GIANT PERFEC Tr. Handsome tall variety. Mixed colors Pkt., 10c.

CUT AND COMT A G A I I (Dresden's Perpetual). A large early flowering stock, which blooms perpet ually and also makes a fine cut flower. Pkt. $10 \mathrm{c}$.

WINT R O BROMPTON'S. Perennial; late flowering. Pkt., 10c.

GIANTS OF NICE TEN-WIERS STOCK A new strain of this favorite of all flower lovers, that is of splendid branching habit, of symmetrical form, bears flowers unusually large and lovely scented. Valuable either for bedding or pot culture. Monte Carlo, canary yellow, pkt., $10 \mathrm{c}$. Casino, light blue, pkt. 10c. Moulin Rouge, blood red, pkt., $10 \mathrm{c}$.

THUNBERGIA OI BIACK - IYID SU SAN. A rapid-growing climber attaining a height of 6 to 8 feet, densely clothed with neat, green foliage not affected by insects; the small single flowers of various colors are freely produced. A pretty vine for trellis. fences, rock-work, etc. Though tender perennials, they are usually grown as annuals. Mixed colors. Pkt. $10 \mathrm{c}$. 


\section{FLOWER SEEDS -Continued}

TAGETES, ALTA (Signata Pumila). A drvarf, compact bushy annual Marigold, with beautiful, delicate, fern like leaves, densely covered with flowers of bright golden yellow; a first-class border plant. Pkt., 5c; $1 / 4$ oz., 30c.

TIGRINUS (Monkey Flower). Fine mixed spotted varieties. Pkt., $10 \mathrm{c}$.

QUFEN'S PRIZE. A remarkably fine selection of M. Tigrinus. The flowers are large and most brightly colored and spotted; the colors are yellow, orange, coppery red and pink. Perennial, 12 inches high and does well, preferring cool location. Pkt., $15 \mathrm{c}$

TRITOMA (Red Hot Poker). A very attractive erennial that makes a fine showing in a garden. The spike grows four feet tall, and of ten contains over a hundred bright orange, scarlet and yellow flowers. Pkt., $15 \mathrm{c}$.

TWIFDINANA. Yellow. Pkt., 10c.

VATERIA. Flowers like Centranthus. Does well in half shade. A hardy perennial. Plkt., $5 \mathrm{c}$.

VFRBFNA. A half hardy trailing perennial of easy culture that blooms the first year from seed. Use care in starting them, as the seeds are slow to germinate, and soaking them in warm water hastens germination. Is a well known bedding and border plant. Pink, white, purple, blue, scarlet and mixed. Pkt., $10 \mathrm{c}$.

VIOLET. Single California variety; grow readily from seed, and produce a very fragrant blosnom. Large flowering, blue. Pkt., $10 \mathrm{c}$. Double Sweet Scented, very large, blue. Pkt., 10c.

VIOIAS (Tufted Pansies). These flowers are not as large as the regular pansies but bloom so profusely that they are preferable to pansios when bedding effects are desired, the colors being very clear and distinct. They bloom for a much longer time. Seed sown in April will produce flowering plants in June, which will continue to be a mass of bloom until the frost eatches them. Conuta, mixed, pkt., 10c. Purple Queen, pkt., 10c. Mauve Queen, pkt., 10c. Coerulea Admiration, dark blue, pkt., 10c. Admirabilis, new hybrids which contain all the varied and brilliant colorings of the best grade of blotched pansies, pkt., 10c. Odorata, The Czar, fragrant and everblooming, blue, pkt., 10c.

VINCA (Madagascar Periwinkle, or Old Irasd). Ornamental free-blooming plants and one of the most satisfactory flowering bedding plants we have. It is best to start the seed early indoors or in a hot-bed, but they begin blooming in $\mathrm{Au}$ gust from seed sown out of doors in May, or as soon as the ground is warm, continuing until frost; or they may be potted and kept in bloom through the winter; a fine cut flower, every bud opening when placed in water. Pkt., $10 \mathrm{c}$.
VISCARIA (Rose of Heaven). Very free-blooming annual, closely allied to the Lychnis; they form compact plants about a foot high, and are covered from early summer till fall with their bright flowers, shaped sornewhat like a single Pink, borne on long, slender stems; it is best to sow them where they are to bloom, thinning out to prevent overcrowding. Pkt., 10c.

\section{WALLFLOWER}

Well-known deliciously fragrant half-hardy perennials, blooming early in the spring, with spikes of beautiful flowers. They should be protected in a cold frame in the winter and planted out in April. We have some extra select seeds of newer type and varieties that are wonderful. Pkt., 10c.

VIOIFT BIUE WATIFIOWFR, A rare novelty that has attracted considerable attention wherever shown. Is a tall branching variety and a beautiful specimen. Pkt., $15 \mathrm{c}$.

vulcan. A dwarf, neat-habited maroon variety. Makes a splendid bedding plant. Height 9 inches to 1 foot. Pkt., $10 \mathrm{c}$.

vesuvius. A very handsome, effective flower, color, scarlet. Pkt., $10 \mathrm{c}$.

Goliath. A splendid single variety, flowers of a rich, shining red with a black velvety sheen. Pkt., 10c.

Golden King. Flowers a rich, bright yellow. Pkt., 10c.

Dresden Forcing. Color dark brown. Pkt., 10.c.

Puysle. Color blue. Pkt., 10c. 10c.

Double Dwarf. Finest variety. Mixed. Pkt.,

Single Mixed. A selection of all the best singles. Pkt., 10c.

Tall Double. Golden yellow and brown. Pkt., $10 \mathrm{c}$.

Tall Double Mlixed. Pkt., 5c.

winter rlowering. The newest variety; mixed. Pkt., 25c.

ZINNIAS. The Zinnia is one of the most brilliant, showy and satisfactory of annuals, and has long been a general favorite. The seed can be sown early in the hotbed or light window and transplanted, or sown later in the open ground. They come into flower early in the summer and keep on blooming until hard frost. Pkt., 10c.

ZINNIA FIFGANS. Flowers of gigantic size, 4 to 6 inches across and densely double; plants of strong, luxuriant growth, $2 \frac{1 / 2}{2}$ to 3 feet in height. Comes in all shades and colors. Mixed. Pkt., $10 \mathrm{c}$.

\section{WILD GARDEN FLOWER SEEDS}

The seeds we offer for the "Wild Flower Garden" are a mixture of over one hundred and fifty different varieties, and being mixed can be offered at a much less price than when sold in separate packets. No one, not having such a bed, can form an idea of its beauty, the different seasons of bloom insuring something new almost every day.

Man is born with a natural love for flowers, and all that is necessary is to develop that inborn love during the early years of his life. Why not do so with the children? Encourage them to grow flowers while they are young. Give them a space of their own which they can call their garden. It would be folly to start them with a lot of difficult things to grow. For this reason we have blended several hundreds of easy-growing annuals into one grand mixture, and we suggest that they are given to children to use in their own plot. Such a plot would then be a Mystery Garden, because they would not know what to expect. All the instructions necessary to observe for successful results in such gardens is that the seeds are not sown too thick. With every day from June till November the Mystery Garden would give forth surprises not only fascinating to the young, but also to the old; in fact it might be an interesting feature to have in any garden.

For this mixture we do not use old, discarded seeds, but we import fresh seeds especially for it, and assure our patrons a most enjoyable treat if these seeds are tried. Large pkt., 10c. 


\section{SWEET PEAS \\ GENERAL CULTURE}

The ground where sweet peas are to be grown should be well prepared-if possible, the fall previous. Deep spading or plowing is very essential for the roots love to penetrate into the cooler regions of the soil. Manure placed very deep will help to draw the roots downward. Sweet peas love sun, therefore they should always be planted where they are exposed to the sun all day.

SOW SEIDS FARIY. Sweet peas will produce their strongest roots during the cool, moist months of the spring, so that the sowing should take place as soon as the land can be worked. A little frost will do no harm to sweet peas. The old-fashioned method of sowing seeds in a trench eight inches deep and to cover them later is obsolete. After the soil has been carefully smoothed and raked, draw a line for a straight row and sow three seeds every six inches in the row. Do not cover the seed more than with one-half inch of soil, and if more than one plant should appear in each spot, carefully destroy all but the strongest specimen, so that one plant shows every six inches in the row. Two ounces of seed is sufficient to sow a single row of 100 feet.

Sweet peas grown thus will produce stems and foliage of unusual strength and vigor, and as each plant branches freely from the bottom, the entire row will soon be a mass of foliage, more dense even than under the old-fashioned method of sowing thick.

Other up-to-date dealers will suggest that you sow thick and afterward thin out, but it is utterly impossible to do this satisfactorily, and it constitutes an extravagant waste of seeds and consequently a waste of money. The flowers produced from plants grown as suggested by us are fit for the queen's garden, and will be a revelation to all who try this up-to-date method.

Notwithstanding the smaller number of plants existing in a row, when our suggestions are followed, we can positively assure our patrons that they will be able to pick more fiowers.

\section{WATERING}

Sweet peas must be constantly. supplied with moisture to do well, and we suggest the following: On either side of the row of sweet peas (six inches away from the plant) dig a trench six inches deep and fill same with well decayed stable manure. Let the hose run into the trenches long enough to fill them up complete at least once a day and your sweet peas will never suffer.

\section{GIANT WAVED SPENCERS}

MIXED GIANT SPENCER SWEET PEAS. Composed exclusively of Giant Waved Spencer varicties, blended in proper proportions of bright colors and including several new hybrids of exquisite colors and shades, many of which, when sufficiently trued up, wili be introduced as new-named varieties. Pkt., 10c; өz., 25c; 1/4 lb., 75c; 1 lb., \$2.50. Delivered free in the United States.

\section{NAME AND DESCRIPTION}

\section{Delivered Free in United States}

Pkt. Oz.

2 Afterglow. Banner, rosy-amethyst tinted ultramarine-violet at base; wings, peacock and electric blues. One of the aesthetic new pastel colorings; most effective in cloudy weather or if shaded from hot sun.

Apple Blossom Spencer. Banner bright rose color; wings creamy-blush; a very robust, yrofuse and large flowering -Bicolor" 10

3 Asta Ohn. One of the best lavender Spencers; an exquisite rosy-lavender flowers large and well waved. 10

$\$$ Barbara. A light salmon or shrimppink; large flowers improved by shading; strong grower and very flor-

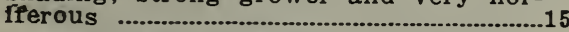

5 Blanche Perry Spencer. Banner deeprose-pink; wings white tinted with blush; a large "Spencer" form of the popular old "pink and white"...................10

- Captain of the Blues Spencer. Banner maroon-purple; wings inagenta-purple; very large flowers ....................................10

7 Clara Curtis. The best of the prim-

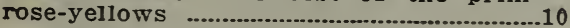

8 Countess Spencer. A re-selected, improved strain of this grand original "pink Spencer" ............................................10

- Dainty spencer. Very large, splendidly formed flowers of blush-white aletinctiy picotte edged with carmine-rose ...10

Dobie's Cream. This is without excepton one of the finest of the Spencers. The color is a beautiful cream, so rich and deep as almost to be classed a Primrose Yellow. It is large flowered and beautifully waved

\section{NAME AND DESCRIPTION}

Plt. Ox.

11 Dublex spencer. A lovely Spencer that is sure to win your admiration. It is a Pinkish Salmon with Rosy Apricot. Flowers large and many doubled............15

12 Edith Taylor. Extra fine and large flowers of rich salmon-rose or cerise; a very lively warm color; strong grower and free bloomer.

18 Flfrida Pearson. Magnificent flower of blush pink, deepening towards the

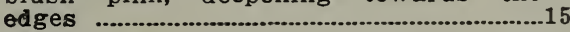

4 Enchantress. True pink, one of the older types still very popular.................10

16 ztta Dyke. This beautiful, giant waved Spencer is pure white in color, very Florence Morge spencer. Very large wavy flowers of soft blush-pink Ilushed towards edge with deeper pink..10

17 Florence Nightingale. Large lavender with pinkish sheen.......................................10

18 Frank Dolby. Large, waved flowers of pale lavender of Unwin form. Fine for sowing in quantities ....................................10

19 George Herbert. A very showy variety with fine large flowers, beautifully waved and of bright carmine rose........10

20 Helen Iewis. A very large and fine orange-rose; wings orange-salmon........10

21 Hercules. Too much cannot be said in praise of this variety..................... 5

22 John Ingman. One of the richest appearing varieties, of unusual size; a deep rose color and orchid waved..........10.

23 ring Edward Spencer. A re-selected improved strain and the best of all the crimsons here noted; color rich crimson-scarlet; large open form; waved flowers of the largest size.......................10 
By the use of fertilizers you wan produoe a surplus-Try it

\section{SWEET PEAS - Continued}

24 King white. Hailed as the King of Whites, because of the perfect finish of the flower in every detail-form, size, waviness and glistening, immaculate whiteness ............................................15 25 Margaret Madison. Large clear pale

6 margaret Atlee. Perhaps the finest of the new Spencers; immense flowers of the loveliest coloring; a rich warm salmon-pink over a body color of cream which lights up the whole flower into exquisite beauty ..............................................15

27 Mary Garden. A most dainty and lovable variety. Large waved blossoms of an exquisite cream pink.............................10

28 Masterpiece Large wavy lavender tinted mauve .................................................10

29 Maud Holmes. An unsurpassed "Sunproof" crimson .........................................10

30 Mrrs. Cuthbertson. Carmine-rose banner and blush-white wings........................10

31 Mrs. Beiberstedt. Pinkish lavender with deep lavender wings.......................10

32 Mrs. Fugh Dickson. A large and fine "cream-pink" ...........................................15

33. Mrs. Routzahn. A favorite "creampink"; a blending of straw color tinted blush-pink and rosy-apricot......................10

34 Nell Gwynn. Salmon pink shaded in to buff; wings striped.......................................10

35 Othello. A rich deep maroon; immense flowers of the finest waved Spencer form

86 Primrose spencer. A waved clear primrose producing exceedingly large flower

37 Royal Purple. A rich royal-purple which coloring is carried throughout both banner and wings; the flowers are of splendid size and form on long stems; vines vigorous and free...-..-...15

38 Senator Spencer. A large and fine striped seal-brown with claret colored flakes on white ground.-...-..-10

30 Sterling stent. Rich deep salmon suffused with fiery orange; needs shading--10

10 Tennant Spencer. A large, waved Spencer of a most unusual purplish rosy mauve. You should try this delightful variety

41 Thomas Stevenson. Vermillion Brilliant. The most brilliant non-fading scarlet spencer yet produced -

43 Wedgewood Blue. A clear light silveryblue with just a suggestion of mauve in the banner; the best variety of its color

44 Winnifred Deal. White with picotte pink wings. A ne $\mathrm{w}$ variety 45 White spencer. Pure white, the standard variety
35

30

40

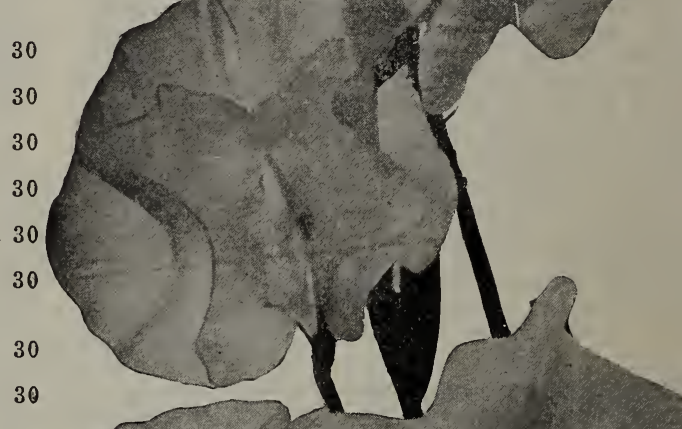

30

30

30

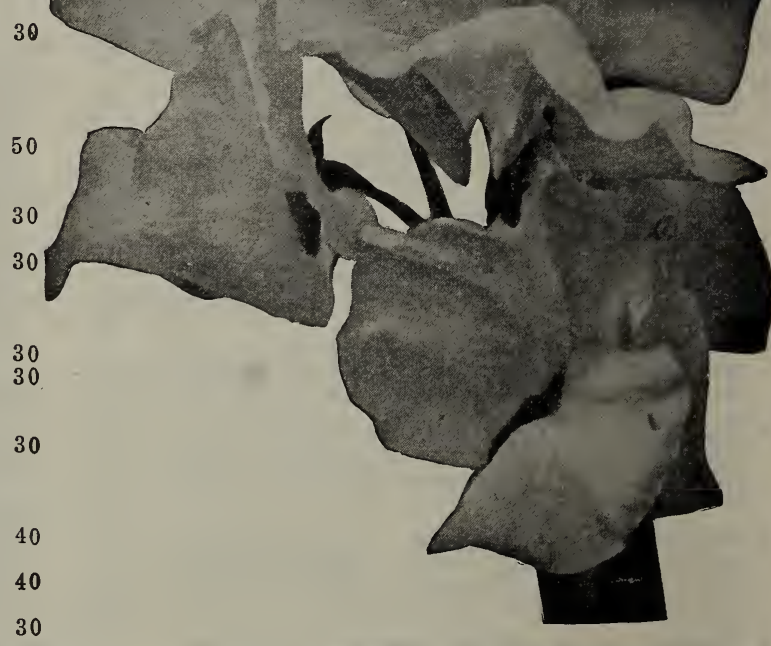

\section{OUR 50c SPECIAL}

A Collection of six different colored Sweet Peas for $50 \mathrm{c}$

\section{Asta Ohn}

Lavender

Etta Dike Pure White

Margaret Madison

Page 58
Mrs. Hugh Dickson

Cream-pink

Royal Purple

Purple

Vermillion

Brilliant Scarlet 


\section{$\$ 1.00$}

\section{OUR SPECIAL OFFERING}

$\$ 1.00$

Don't fail to take advantage of this splendid offer

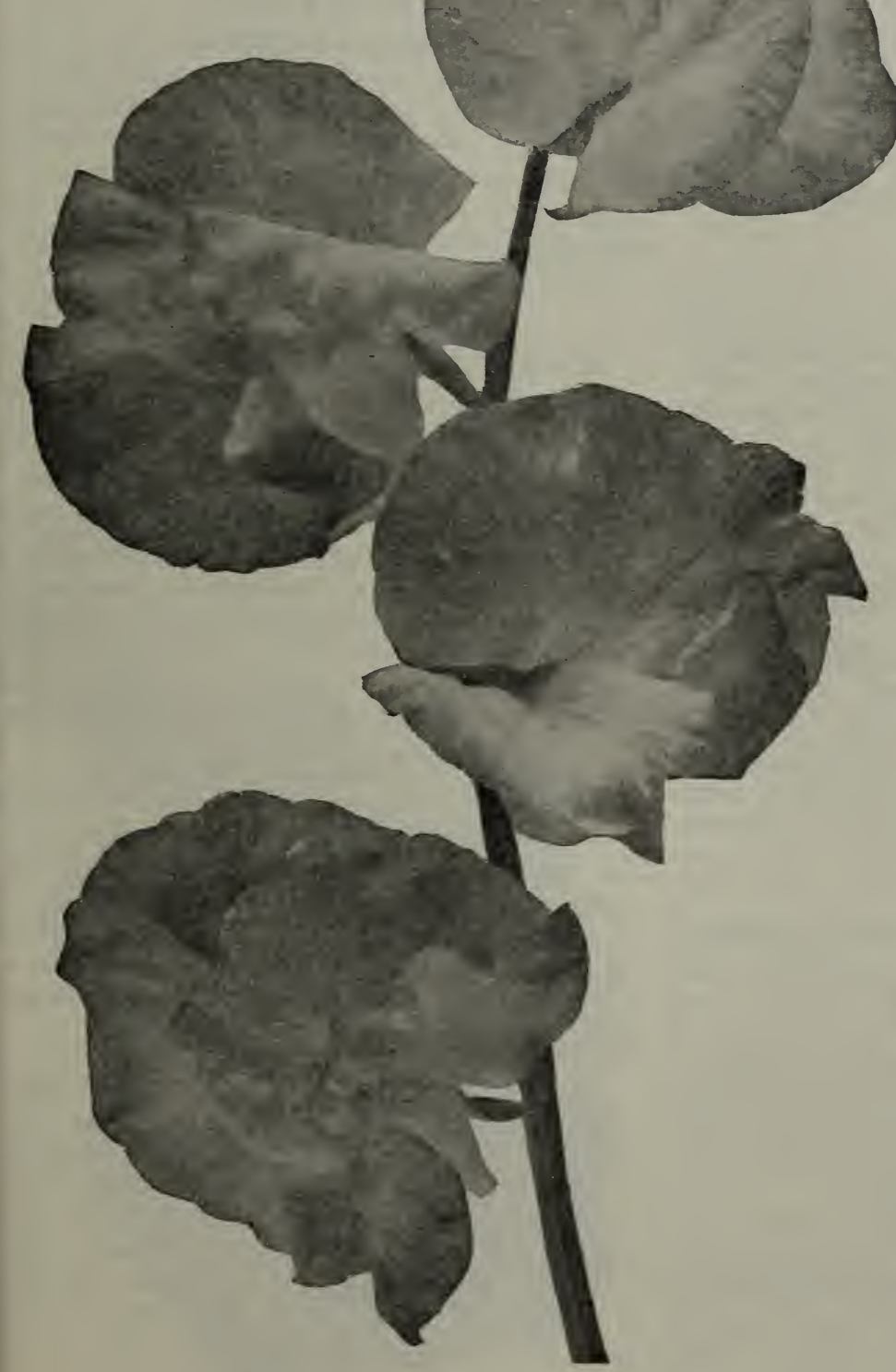

\section{0 \\ Different Colored Sweet Peas for $\$ 1.00$}

King White

Best Pure White

Dobie's Cream

Cream Spencer

Wedgewood

Porcelain-blue

Illuminator

Brilliant Salmon Cerise

King Edward VII Best Red

Margaret Atlee Best Deep Cream-pink Marion Beaver Best Light Cream-pink Orchid

Best Lavender

Robert Syndenham Orange

Royal Purple

A Rich Deep Purple

Regular Price $\$ 2.00$ 


\section{PLANT DEPARTMENT}

\section{Annual and Hardy House Plants}

\section{AGERATUM}

Useful in all summer bedding schemes, as well as for baskets and vases. In fact they are indispensable for these purposes on account of the serious lack of blue shades among bedding plants.

BLUE PERFECTION. Large clusters, bright blue with purplish shading. $15 \mathrm{c} ; \$ 1.50$ per doz.

\section{ASPARAGUS FERNS}

Brilliant, dark green foliage plants, unquestionably the most used of any indoor trailing plants for bracketed pots, window-boxes and hanging baskets.

PLUMOSUS NANUS. The lace-like texture of its foliage outclasses Maiden Hair Fern for grace and daintiness; the long sprays being indispensable for floral decorations. Excellent alone or as center plant in jardinieres. Each 50c to $\$ 1.00$.

SPRENGERI. Mostly used for hanging baskets where its long, dense trails make a gleaming mass of green. Each 50c to $\$ 1.00$.

\section{ANNUAL ASTERS}

CREGO'S GIANT COMET ASTERS. We consider this the finest and largest of all Comet Asters, bearing immense fluffy flowers five inches and over in diameter, as fine as any Chrysanthemum, and when cut keep in good condition longer than any other of this type. We offer five colors, viz.: Pure white, delicate shell-pink, bright purple, rich deep rose, deep lavender. Doz., 50c.

SEMPLE'S LATE FLOWERING ASTERS. Superior late flowering branching Asters. The flowers are large, very double and borne on long stems. They begin blooming about the first of September. Plants strong growers, 18 inches to 2 feet high. White, lavender, purple, crimson, shell-pink (Mary Semple), light blue. Doz. 35c.

\section{AL YSSUM}

ALYSSUM (Mad Wort). Pretty little plants for beds, vases, baskets, edging or rockwork, blooming profusely all summer; useful also for winter flowering. Very sweetly scented. Doz., $50 \mathrm{c}$.
LITTLE GEM, or CARPET OF SNOW. Of dwarf, compact habit, but 4 inches high. It begins to bloom when quite small, and the plants are a solid mass of white from spring to late in autumn, and undoubtedly the best white flowering edging plant in the list. Doz., 50c; pot grown, 1.00 .

\section{DRACENAS}

The several varieties of this family are considered among the best of decorative foliage plants, and are largely used for conservatory and house adornment. They should be given a light fibrous soil with good drainage, liberal watering with frequent showers; and to ensure the greatest development of color, let them have all the sunshine available. Plants, $\$ 1.50$ to $\$ 2.50$ each.

\section{FORGET-ME-NOTS}

MYOSOTIS. The large spring-flowering Forget Me Not, with intense sky-blue flowers, bright and attractive. Per doz., $\$ 1.00$.

\section{FUCHSIAS}

These plants were a few years a go among the most highly prized for winter blooming in the ordinary dwellings, and despite the innovations which have been crowding in of late, to supply our window boxes and plant stands, they are still largely used; and are popular for summer beds in partially shaded situations. Each, 35c to $\$ 1.00$.

\section{GERANIUMS}

In this, the most popular bedding plant the world over, we are offering this season some new varieties that have taken the. garden world by storm, and also the old standard favorites of long proven worth and desirability. These plants will make a splendid showing at once. Prices on all Geraniums: each, 25c; doz., $\$ 2.00$, plus postage

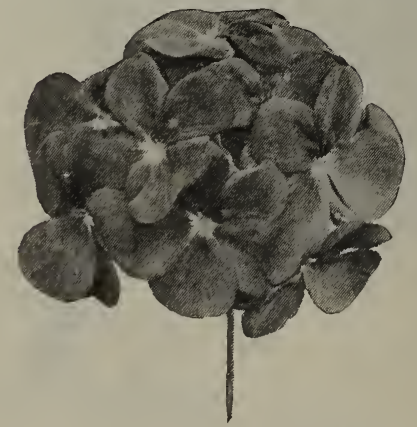

SINGLE VARIETIES (Mrs. G. Hill). A beautiful salmon pink, producing an extra large flower. Finest pink yet produced, both in size and color. 


\section{PLANT DEPARTMENT—Continued}

IVY GERANIUM. This class of Geranium has a trailing habit and is unexcelled for baskets, vases and window boxes. Deep green, ivy-shaped leaves and brilliant colored flowers. Large plants, in bloom, each 3jc; doz., \$3.50. Small plants, each, 25c; doz., \$2.50.

PELARGONIUM Or LADY WASHINGTON. Like other Geraniums, they flower during the summer months and are very ornamental either as house or bedding plants. Blush white, cerise, crimson, salmon and pink, blotched with maroon and mahogany. Velvety petals. Each, 50c to $\$ 1.00$.

\section{HELIOTROPE}

A fine garden plant. Very fragrant. Lavender flowers. One plant will grow from fifty to one hundred blooms. Each $25 \mathrm{c}$ to $35 \mathrm{c}$.

\section{LOBELIA}

LOBELIA PLANTS (Dwarf). Blue and White in single and double. Plants grown in flats, each $5 \mathrm{c}$; doz. 50c. Plants grown in pots, each, $10 \mathrm{c}$ doz., \$1.00.

LOBELIA (Trailing). White and Blue. Prices same as above.

\section{PANSY PLANTS}

If you wish to enjoy pansies of absolute perfection in form, coloring and size this summer, you can have them in the two varieties of our famous pansy plants listed below. Every flower is a gem and a bed of them is a picture to behold.

In them may be found colors of wondrous richness and effectiveness and also the alluring delicacy and beauty of the pastel shades.

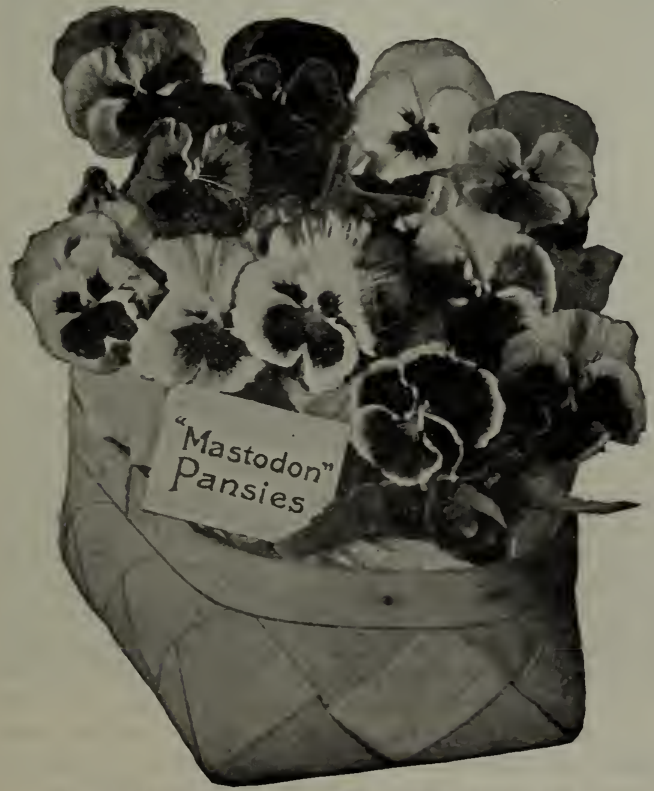

READY FROM MARCH TO JUNE
MASTODON. A strain of surpassing excellence for giant size. substance, form and coloring Plants are in full bloom and packed a dozen in a basket. Per basket, $\$ 1.25$. Postage extra.

GIANT MASTERPIECE. A pansy of infinite grace and loveliness; of rich, velvety coloring, the immense petals beautifully waved in true orchid effect. Our price on these is very special and a rare value. Doz., 75c. Postage extra.

\section{PETUNIAS}

PETUNIA (The Virginian). A beautiful new single-flowered variety, very popular last season for bedding and window boxes. Large fringed blooms of a soft bright pink shaded to yellow and white in the center. Each 25c; doz., $\$ 2.00$.

PETUNIA (Double). White, Lavender and Purple. Each, 15c; doz., \$1.50.

\section{SALVIA}

SALVIA, New Zurich. A distinct and attractive variety, of compact, dwarf growth. The plants are of neatly rounded form and only 18 inches high, closely set with stiffly erect spikes of the bright scarlet flowers. Each, 25c.

\section{VERBENA}

VERBENA (New Mammoth). The Verbena is, next to the Geranium, the most popular of all bedding plants. They commence to flower and spread the first day the plants are set out and continue growing more beautiful until late in the Fall. The New Mammoth strains are noted for their robust growth and immense flowers. The colors range through the different shades of blue, pink, scarlet, white, purple, crimson, and some variegated. Each, 10c; doz., \$1.00.

\section{VINCA}

Variegated for boxes and baskets. Each, 3ðc

\section{Any variety of Plants, Ferns} etc. not enumerated in this list we shall be pleased to supply at prevailing prices. 
These varieties have found favor wherever tried

\section{HOW TO GROW ROSES}

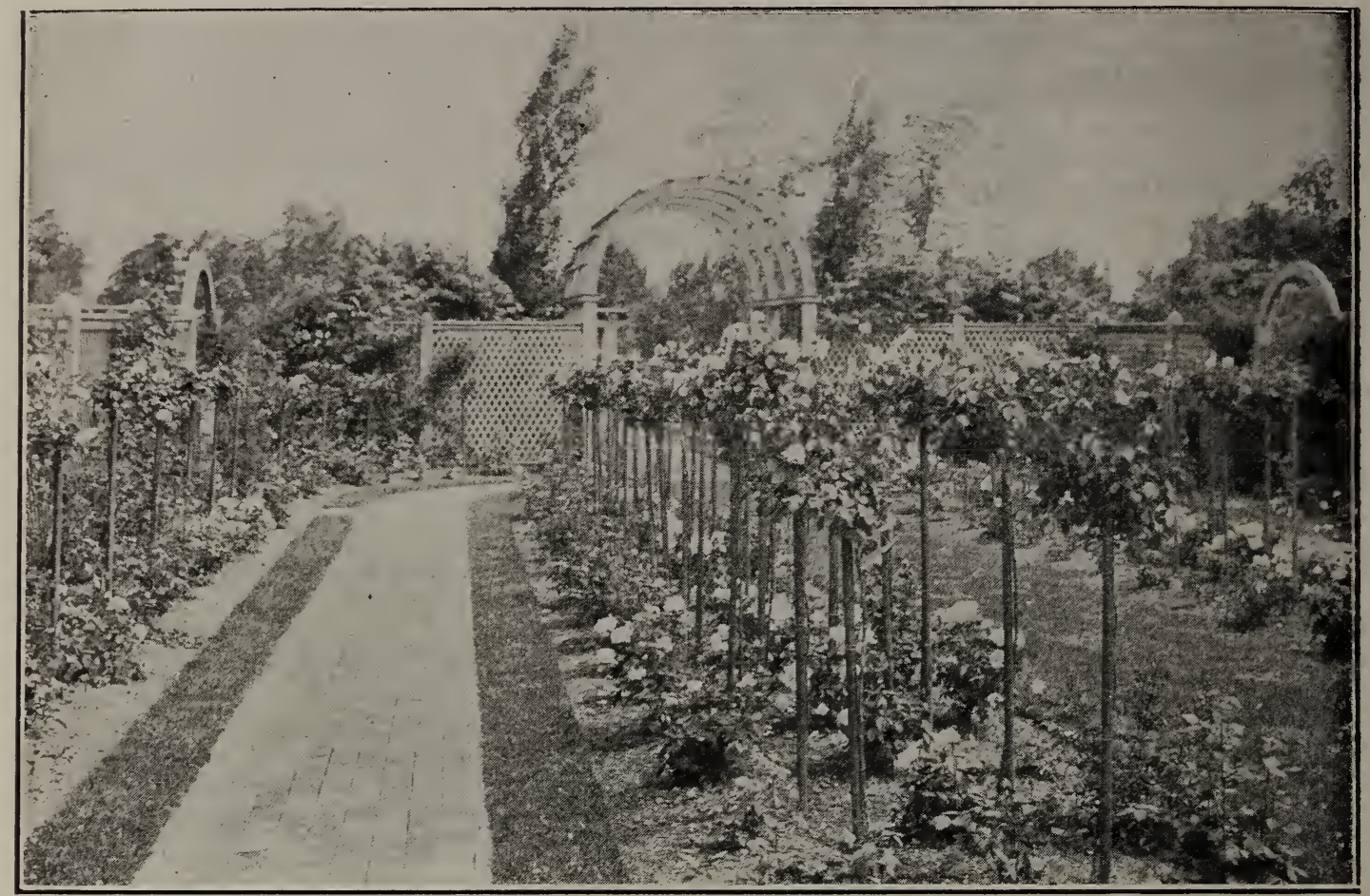

T OCATION OF BEDS-Roses should be planted where they will be open to sunlight for at least half of each day. In locating beds, avoid trees, shrubbery and shady sides of buildings and fences. This will lessen the danger from insects and diseases.

SoIL-Any good garden soil, which will grow good vegetables, will grow, with proper fertilization, fine Roses. The ideal soil is a clay loam of -sufficient porosity to permit of ready drainage.

PREPARATION OF BEDS-The beds should not be so large that the Roses cannot be reached without treading on them. Long, narrow beds, with one continuous row of plants, are preferable. Spade the soil to a good depth, mixing in good fertilizer as you do so, and the richer the fertilizer the better results you will have. We manufacture a special rose fertilizer. Whalebone meal is excellent.

PLANTING-Most varieties should be planted about $2 \frac{1}{2}$ feet apart, when the soil is in a nice, mellow condition. Spread the roots out well and press the soil down firmly. Plant slightly deeper than previously grown and give out good watering if weather is warm and dry.

WATERING-Most people water their Roses too much. Once a week is often enough and that early in the morning. Keep the soil mulched or cultivated around the bushes to prevent baking.

MULCHING AND PROTECTION-Only the tenderest varieties need any protection in this country. This can best be supplied by mulching the soil around the plants with a heavy application of cow manure, which should be spaded in the following spring. All plants should have this mulching.

PRUNING-Field-grown dormant Roses should be cut back severely when first set out. Subsequent prunings should be attended to in late winter and early spring, when all dead and weak growth should be removed entirely and the strong, live canes should be shortened back to one or two feet in length, according to the growth of the previous season. It may be accepted as a general rule that weak growth should be pruned severely and strong ones sparingly. Climbing Roses should not be cut back any more than is necessary to keep the plant in a shapely appearance.

BEST TIME FOR PLANTING-No question is asked more frequently than, "When is the best time to plant Roses?" Our dormant field-grown Roses can be planted any time that the soil can be worked, between October and April. Probably the best month is March. Most people plant in that month and with best results. Our small greenhouse-grown Roses should not be planted until a month later, when the soil has warmed up with the increasing strength of the sun's rays. 


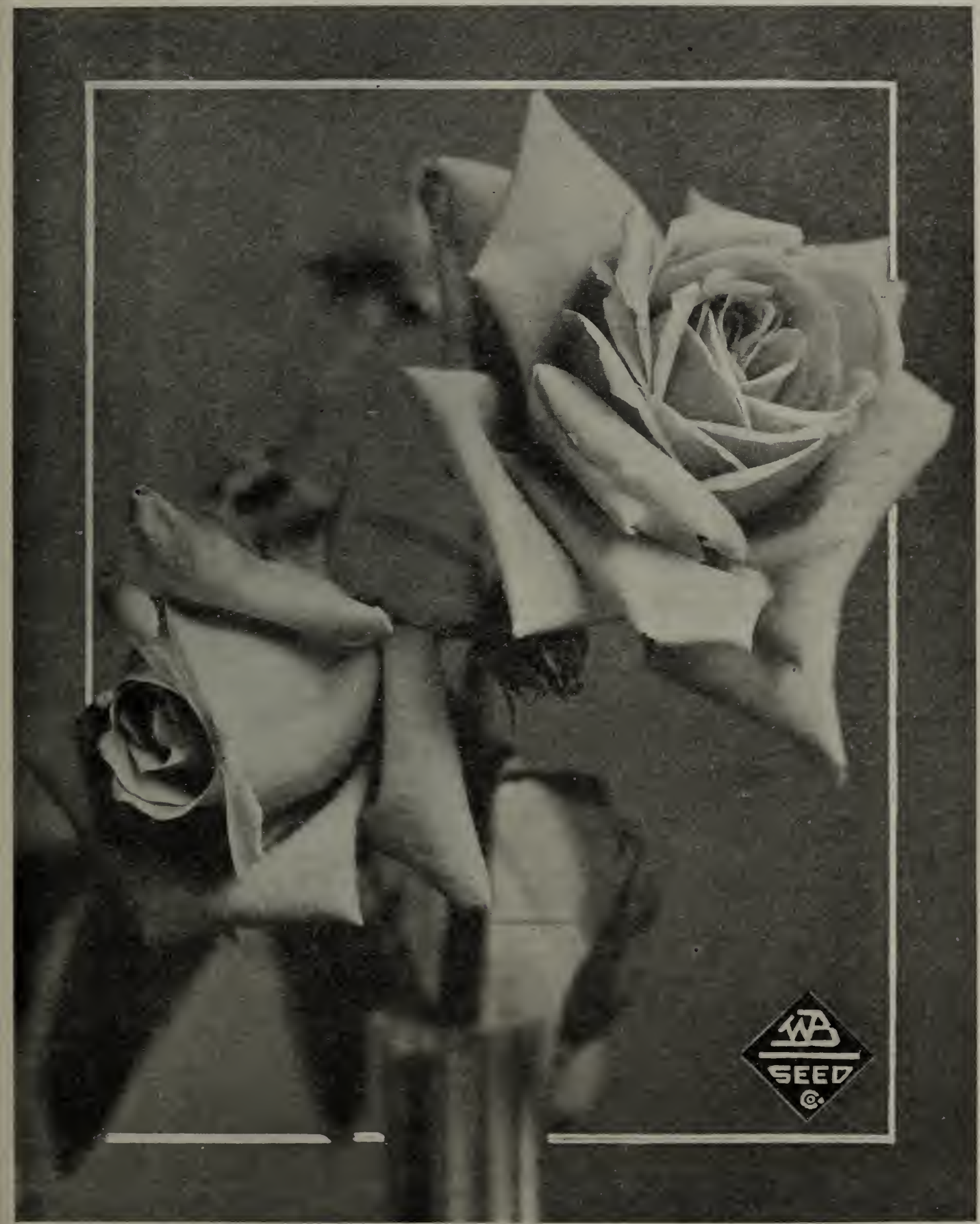

Mme. Melanie Soupert 


\section{“WOODRUFF-BOYCE” ROSES}

\section{ABBREVIATIONS}

T.-TEA-One of the best classes of roses, and truly ever blooming. They are hardy in this section, frequently wintering without any protection, although during our coolest weather and in cold sections they should be protected with a covering of fir boughs, straw or burlap.

I. T.- FYBRID TEA-Most of these are as free

\section{Pink Shades}

ARTHUR R. GOODWIN (A. B.) Pernet Ducher, 1909). This is a genuine "Pernetiana" and is perfectly hardy everywhere. The color is coppery orange-red passing to salmon-pink as the flowers expand. A superb combination of color; flowers medium to large and full. Each $75 \mathrm{c}$.

BFTTY. H. T. A beautiful coppery rose color overspread with golcen yellow; very large and fragrant. One of the best blooming roses in existence. Each $75 \mathrm{c}$.

DOROTHY PAGE ROEERTS H.T. A delightful blossom of coppery-pink, suffused with apricot shadings. Large petals, exquisite buds and flowers. Has won many prizes. Each $75 \mathrm{c}$

DEAN HOIE H.T. An exquisitely beautiful Rose of bright carmine pink color, with silver shadings and with the grandeur of American Beauty in form and foliage. Buds of extraordinary length, opening into a mammoth bloom of splendid substance. Continuous bloomer. Each 75 ic.

ROSE PINK, PINK TRAU KARI DRUSCHKI. H. $\mathbf{P}$ This beautiful rose caused a sensation when first exhibited. A very vigorous grower of erect branching habit. Flowers beautiful tender roses, tinted yellow, large and full. On account of its size and color this variety will soon gain the same popularity as the famous Druschki. Each $\$ 1.00$.

JONKHERR I'MOCK H. T. A most sterling novelty. Flowers which are produced with the greatest freedom; are borne on stiff, erect stems; are large and of perfect form; color, a deep imperial pink; outside petals silvery rose and white, lightly perfumed. Each $\$ 1.00$.

JOSFPF HIII H. T. Fine salmon pink. Shader to a coppery yellow, beautiful long, pointed bud. Each $75 \mathrm{c}$.

KIIIARNEY. F. T. (Alex. Dickson, 1898.) The finest Rose ever introduced. In coloring it is especial, being an exquisite shade of deep seashellpink and flowers are of enormous size, the petals being two and one-half inches deep. Each 75c.

IA FRANCE H. T. Perhaps no Rose is better known or more highly valued than La France. Both flowers and buds are of grand size; color a silvery rose, changing to pink. A general favorite and the sweetest of all roses. Each $75 \mathrm{c}$.

LA TOSCA H. T. A beautiful silvery pink, deep center; very large perfect buds and flowers. Has taken many prizes. Each $75 \mathrm{c}$.

IOS ANGEIES. (Howard and Smith, $1917-$ Originators' description: "Los Angeles is, by all odds, one of the finest roses ever introduced. The growth is very vigorous, and produces a continuous succession of long-stemmed flowers of a luminous flame-pink, toned with coral and shaded with translucent gold at the base of the petal. In richness of fragrance it equals in intensity the finest Marechal Niel. The buds are long and pointed and expand into a flower of mammoth proportions. while the beauty of form and ever increasing wealth of color is maintained from the incipient bud until the last petal drops." Each, $\$ 2.00$

Page 64 flowering and as constant bloomers as the teas, and are hardier, but, as a rule, not so hardy as the H. P's. Many of our best roses are in this class.

Cther appreviations that are often used are:

S.-Single; H. B.-Hybrid Briar; Wich.-Wichuriana; N.-Noisette; Poly.-Polyanthus; Pern.Pernetiana; A. B.-Austrian Briar; R.-Rambler.

IOUIS CATHERINE BRESIAU. H. T. Coral pink. A vigorous grower of robust constitution with fine, glossy green foilage. Large oval shaped bud of coral tint, shaded with chrome yellow, cross between an unknown variety and Soleil d.Or. On account of its distinct coloring this variety will soon gain the same popularity as Lyon Rose, which it surpasses as regards hardiness. Each $\$ 1$.

IYON, $\mathbf{F}, \mathbf{T}$, No rose has been introduced that has won more favor for the last two years than this Grand Rose. No artist can describe its beauty - coral red and salmon pink shaded with chrome yellow in center. Each $\$ 1.00$.

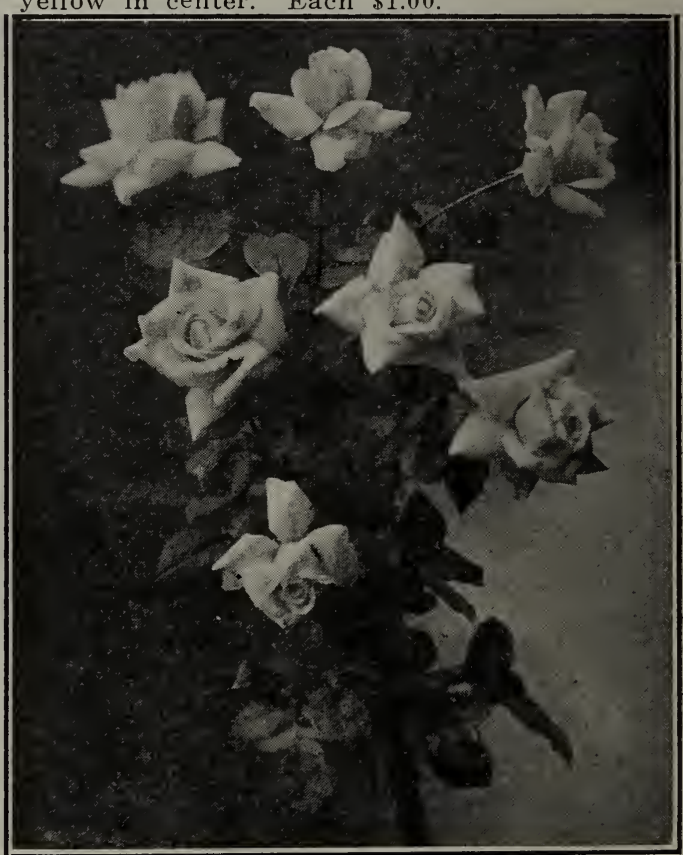

TrSTOUT. H. T. A favorite everywhere and a grand pink Rose. Each, $75 \mathrm{c}$

MIMIE. ABEI ChATENAY. H.T. One of the most popular Roses everywhere, both in the garden and as a cut flower, thousands of its beautiful buds being sold daily on the streets of London. It succeeds equally well here, is a strong grower and produces very freely beautiful flowers of carminerose, shaded with salmon. Each $75 \mathrm{c}$.

MADAME CECIL BRUNNER. Poly. (The Fairy or Sweetheart Rose.) A Polyantha variety with dainty double little flowers of perfect form, produced in many flowered graceful sprays; color a soft rosy-pink on a rich creamy-white ground. Each, $75 \mathrm{c}$.

MLAMAN COCHET. T. One of the most beautiful Tea Roses, vigorous in growth with rich, heavy foliage and very large flowers on long stems. Color deep, rosy pink, inside of petals a silvery rose. Very double, exquisite bud or bloom. Each $75 \mathrm{c}$. 


\section{Pink Shades-Contd.}

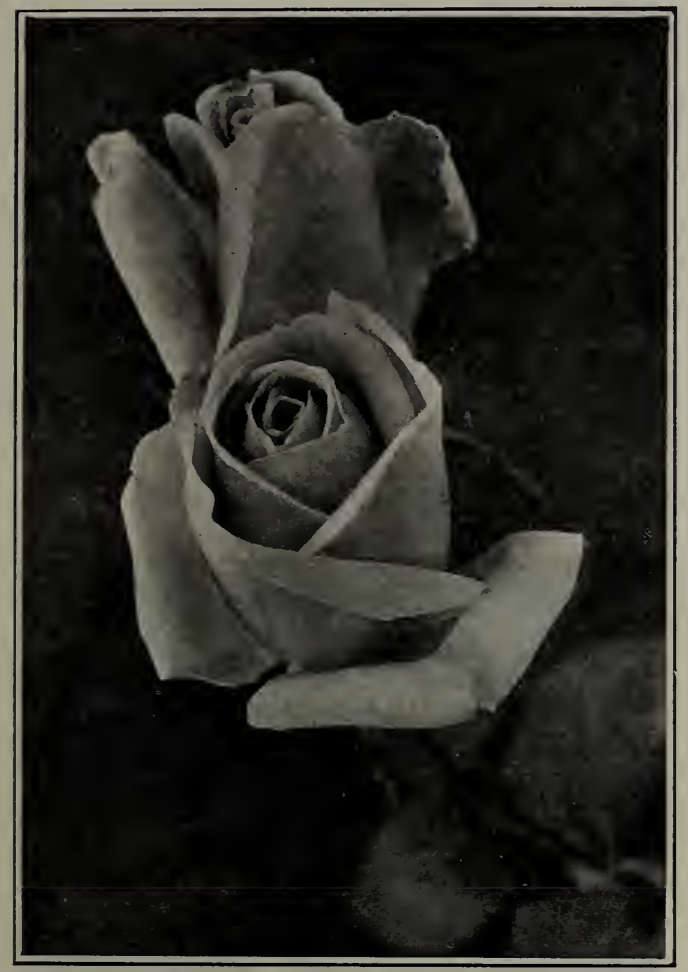

MMTE. MILANIE SOUPERT. (H. T.). (PernetDucher, 1906). For delicay in coloring it would be difficult to surposs this magnificent semidouble large flowered varieity which is especially fine in the but form; in color a charming pale tint of salmon-yellow with pink and carmine suffusinn.

tint. Fach. $\$ 1.00$.- See illustration, page 63 .

MHDDRED GRANT (Alex. Dickson). H. T. Ivory white, with an occasional flush of pale peach. High pointed center with unusually large and massive petals, opening to perfectly formed flowers of enormous size and substance. Awarded the gold medal of N. R. S. It is a grand Rose. Each 75c. MRS. ARTHUR ROBERT WADDELI. H. T. A variety that meets with universal favor. A delicate soft rosy salmon, suffused with a golden sheen; free flowering. A Rose that should be in every collection. Each $75 \mathrm{c}$

Mrs. Jos. H. WrISH. A pink Rose of rare beauty and one which received a great deal of admiration at the last year shows. A true pink of fine shape, deeper at the base, petals long and narrow. Fach $75 \mathrm{c}$.

MRS. JOHN IAING. I.P. Rich Satiny-pink. large and full; delicious fragrance. This fine variety cannot be too highly praised. For freedom of bloom it is unsurpassed in its class. Each $75 \mathrm{c}$.

MRS. SHARMAN CRAWFORD. H.T. Deep, rosy pink; outer petals shading to pale flesh color. One of the finest Roses in every way. Each 75 c.

MY MARYLAND. (H. T.). A grand Rose, with the general habit and coloring of Killarney, but showing a more decided rose-pink. Vigorous grnwer and free bloomer. $75 \mathrm{c}$.

PAUI NEYRON. H.P. Deep, shining Rose; double and handsomely formed; blooms freely and is unusually strong and vigorous; the largest variety in existence, and one of the most desirable for the garden. Each, $75 \mathrm{c}$.
OPHEIIA. H. T. Salmon pink shaded with rose at the base. Flowers large and exceedingly well shaped, long bud opening to large, full flower; free bloomer. Each $75 \mathrm{c}$.

PRESIDENT CARNOT. H. T. A rosy flesh Rose and shaded with a iighter tint at the end of the petals. Flowers very larye, both in bud and blossom. Very fine and fragrant. Each $75 \mathrm{c}$.

PRINCE DE BUIGARIF. H. T. Salmon pink, silvery flesh very delicately shaded with salmon, long bud opening to full cup-formed flowers; a distinct and very charming variety. Mark the prediction, "Prince de Julgarie" will be in the forefront of all forcing roses. Each, $75 \mathrm{c}$.

WIIIIAM SHFAN. H. T. Purest pink, petals shell shaped, four to five inches long; flowers of immense size and substance and of perfect form; free blooming and distinct. Gold Medal, N. R. S. You will have to travel a long ways before you beat this Rose for the garden. Each. $\$ 1.00$.

WINNIE DAVIS. Rich apricot pink, shading to flesh color; has a beautifully formed bud and bloom. Blooms all the time and is a great favorite. Each, 75c.

WIIIOWMIER (Pernet-Ducher, 1914). B. This splendid introduction is of a coral-red color, suffused with carmine in the bud state, and opens to a large, full, handsome flower of a rich shrimppink, shaded yellow in the center and flushed carmine-pink towards the edges of the petals. It may be described as an advance on the Lyon Rose, which it much resembles. Each, \$1.50.

\section{RED SHADES}

AMFRICAN BEAUTY. (H. P.) One of the largest, sweetest and best; color rich rosy crimson, shaded and veined in the most charming manner. Each, $75 \mathrm{c}$.

AVOCA. (H. T.) Deep scarlet crimson flowers of perfect form: very fragrant. Each, $75 \mathrm{c}$

AUTUMN TINTS. Color, coppery red shaded with orange and salmon. medium size flowers, produced in great profusion throughout the summer and autumn: the growth is strong and branching, and the foliage a rich bronzy green, not liable to mildew. An exceedingly attractive bedding and decorative variety of similar colnring to Madame Edouard Herriot. Each, $\$ 1.50$.

BLACK PRINCE (Fybrid Perpetual). One of the finest Roses of its class. The color is dark velvety crimson, passing to intense maroon and velvety crimson, passing
shaded black. Each, $75 \mathrm{c}$.

EDWARD MAWIEY. H. T. (McGredy, 1917.) A rose with a delightfully velvety gloss on the petals, which are a beautiful rich crimson, touched with maroon. Awarded a Gold Medal by the National Rose Society. Each, $75 \mathrm{c}$.

GEORGE DICKSON. H. T. The color is velvety blackish crimson with brilliant scarlet reflex ed tips. It is a rose that is always there. be the weather what it may. Produces huge blossoms quite five inches across. The best red rose ever produced. Each, $\$ 1.00$.

PAPA GONTIER. T. A magnificent red Rose: flowers are large and semi-double; a vivid cherryred color, shaded yellow. reverse of petals crimson; free growing and flowering very profusely. One of the very best for open ground. No other red Tea Rose can compare with it. Each $75 \mathrm{c}$.

GENERAI MCARTHUR. H. T. Elegant scarlet sunproof; keeps its color to perfection. Free bloomer. Each, $75 \mathrm{c}$.

GENERAI JACQUEMNOT. H.P. Bright shining crimson, very rich and velvety, exceedingly brilliant and handsome; makes magnificent buds and is highly esteemed as one of the best and most desirable for open ground. Each, $75 \mathrm{c}$. 
Our seeds insure you a prolifio crop.

\section{RED SHADES-Contd.}

GRUSS AN TEPITIZ. (F. T.) (Geschwindt, 189S.) Bright crimson white, fiery-red center; cupshaped; semi-double; flowers in clusters; so free in bloom as to present a blaze of scarlet. Each, $75 \mathrm{c}$

HUGI DICKSON. (H. P.). One of Hugh Dickson's best red roses. Simply a marvel of beauty.

FIS MAJESTY. (H, T.) A rich dark crimson, shaded deep vermilion; beautiful in bud when full blown. Each. $\$ 1.00$.

JUIIET. (F. B.). Is without question the finest deep crimson Hybrid Tea Rose in cultivation and takes prizes wherever shown. Perfect bloomer. Each, $75 \mathrm{c}$.

J. B. CIARK. (H. T.) Deep scarlet shaded blackish crimson, large and beautiful. Each, $75 \mathrm{c}$.

KING GEORGE. (H. T.). The color is quite unique amongst Hybrid Tea Roses, being blackishcrimson with deep velvety-violet flush. A striking and brilliant color. The perfume is strong and pleasing. Strong growth, large foliage. Each, $\$ 1.00$.

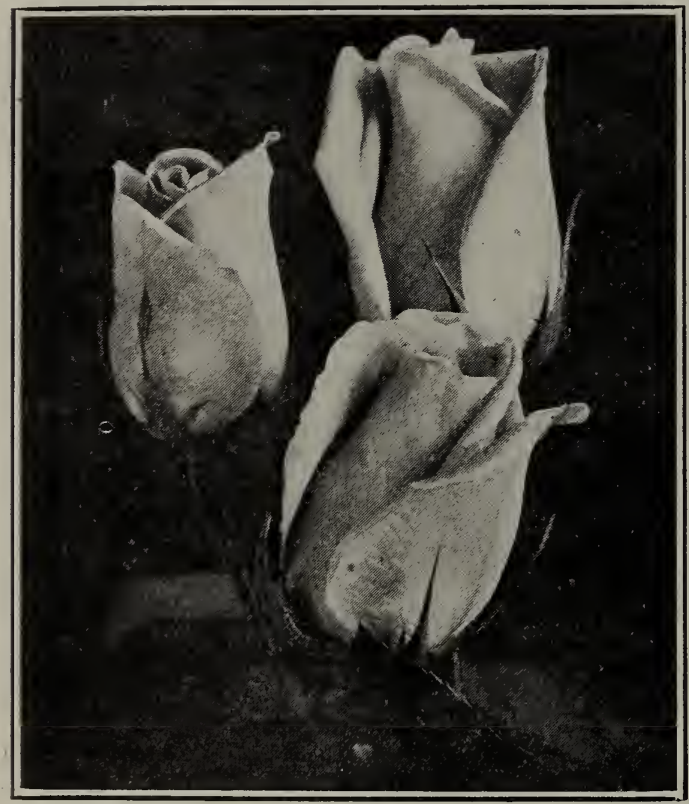

IADY BATTERSEA (Red Tiphetos). (H. T.) Beautiful cherry-crimson; buds long and pointed. sweetest of all Roses. Each, 75c.

IAURENT CARIF. (F. T.). One of the finest brilliant carmine-colored roses we have ever seen. Flowers of immense size and substance, and of exceedingly perfect form. We have some exira fine stock of this and look for fine results. Each,

IIBERTY. (H. T.). Rich, velvety-crimson, long, pointed bud; free-flowering. Each, 75c.

MMP. FDOUARD FFRRIOT (The Daily Mall Rose). (H. T.). This variety gained great prominence in Europe as the "Daily Mail Rose." The combination of color shown in the buds and flowers is distinct and charming. In the bud it is coral-red shaded with yellow at the base, the open flowers coral-red shaded with yellow and bright rosy-scarlet, passing to shrimp-red; flowers of medium size, well formed and not too full. A most vigorous grower, of a spreading, branching habit, with ample bronze-green foliage. Price, strong imported plants, each, $\$ 1.00$.
PRINCF CAMIIIF DF ROFAN. (H. P.) Very dark, rich, velvety crimson, passing to intense maroon, shaded black; regarded as the best of its color. Each, 75c.

RHEA REID. (H. P.) A new American Rose which can best be described as being as red as a "Richmond," as large as an "American Beauty," with the fragrance of "La France," and bloorns continuously, flowers being borne on long stems; very hardy and vigorous. Gold Medal Paris, 1908. Each, 75c.

RICFMOND. (H. T.) A splendid new American Rose of great merit. Strong in growth, splendid foliage and long stems. Color, a magnificent rich scarlet-crimson, the most vivid we have yet seen among ever-blooming roses. Is being grown largely by florists for cut flowers. Price, two-yearold plants, 75 c.

UIRICF BRUNNRR. (H. P.). This is really a magnificent Rose; extra large, bold flowers, iull and globular; petals large and of a good substance; color rich, glowing crimson, elegantly flamed with scarlet; a good grower and free bloomer; one of the best for forcing. Each, $75 \mathrm{c}$.

\section{YELLOW SHADES}

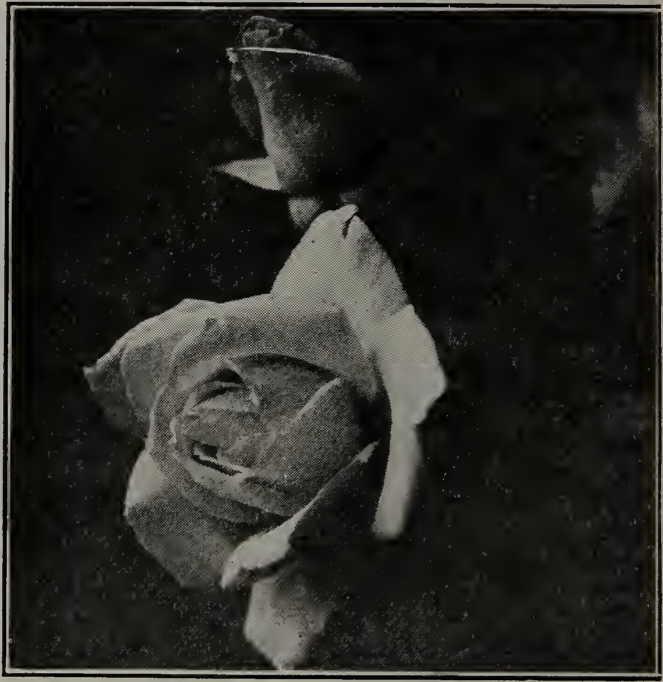

DUCHESS OF WEIIINGTON. (I. T.). A grand Rose of the famous Killarney type, but of an entirely distinct color from any rose now in cultivation, it being of an intense saffron-yellow stained with crimson in the first stage, which, as the flowers develop, changes to a deep, coppery, saffron-yellow. The flowers, which are fairly full, resemble Killarney in shape, but the petals ale larger and of greater substance. Delightfully fragrant and very free-flowering. Each, $\$ 1.000$.

BHAUTY DY IYON (Fybrid Austrian Brier). Forms a large, globular flower of splendid shape, of a coral red color shaded with yellow. Beautiful, large, rich, glossy foliage. Very desirable añi free. Each, $75 \mathrm{c}$.

FARRY TIRK. (T.). Awarded Gold Medal by the National Rose Society of England. Deep sulphur yellow. Each, $75 \mathrm{c}$.

IEISH FIRE FIAME. (F. T.). The flowers of this exquisite variety are single. In the bud state it is deep orange splashed with crimson, which as the bud develops becomes fiery orangecrimson, changing to delicate orange in the fully opened flower. Deliciously fragrant. A grand Rose that should be in every garden. Atvarded Gold Medal of the National Rose Society of London. Vigorous two-rear old plants, each, $\$ 1.00$. 


\section{YELLOW SHADES-Contd.}

IRISH EIEGANS. (F. T.). The largest and most beautiful of all single Roses; a great bloomer. Fine orange color. alnars in bloom and a great show in any garden. Each, $75 \mathrm{c}$.

IADY PIERRE. (H. T.) A deep coppery, reddish salmon colored Rose, of fine growth; produces beautifully shaped buds on long stems and exceedingly choice rariety. Each, $75 \mathrm{c}$.

IADY HILIINGTON. (H. T.). A deep apricot rellon. very long, pointed buds and rery freeflowering. Superb variety. Each, T5c.

IE PROGRESS. (H. T.). Nankin yellow, open to saffron yellow. Flowers large and full and crect stems. Fine bloomers and one that will always be a farorite. Each, 75c.

MARIE VAN HOUTTE. Of fine, faultless strawyellow color; outer petals washed and outlined with a bright rosy carmine; occasionally the whole flower will be suffused with a light pink. Each. $40 \mathrm{c}$.

MMME. RAVARY. (H. T.). Should be in every collection on account of its distinct color, which is of a rich. deep nankeen-yellow, becoming lighter as the flower expands. The flowers are of splendir form, full, double and very fragrant. Each, $75 \mathrm{c}$

MADAME IEON PAIN. (F. T.). Handsome plum color foliage olange vellow salmon center: reverse bright red, vellow. A grand Rose. Each, โร.

MRS. AARON WARD. (F. T.). Color, Indian ellow. One of the finest of all yellow roses; very free bloomer. Each, $75 \mathrm{c}$.

MEIODY. (H. T.) Intense deep saffron yellsw with primrose edges. Blooms are of medium size, very fragrant and freely produced. An excellent bedding and forcing variety. Each. T5c.

PIERRE NOTTING. (Soupert \& Notting 1901.) Color apricot yellow blended with coppery-yellow; long bud opening to large, full flower. Gold medal, N. P. S. Each, 75 c.

RAYOA D'OS (Golden RaRYs). (H. T.). Don't be without one or more. A gorgeous new goldenyellow Rose, vigorous and strong grower with glossy foliage. Not susceptible to mildew. Flowers large and of globular form. A show by itself in any garden. Each, $75 \mathrm{c}$.

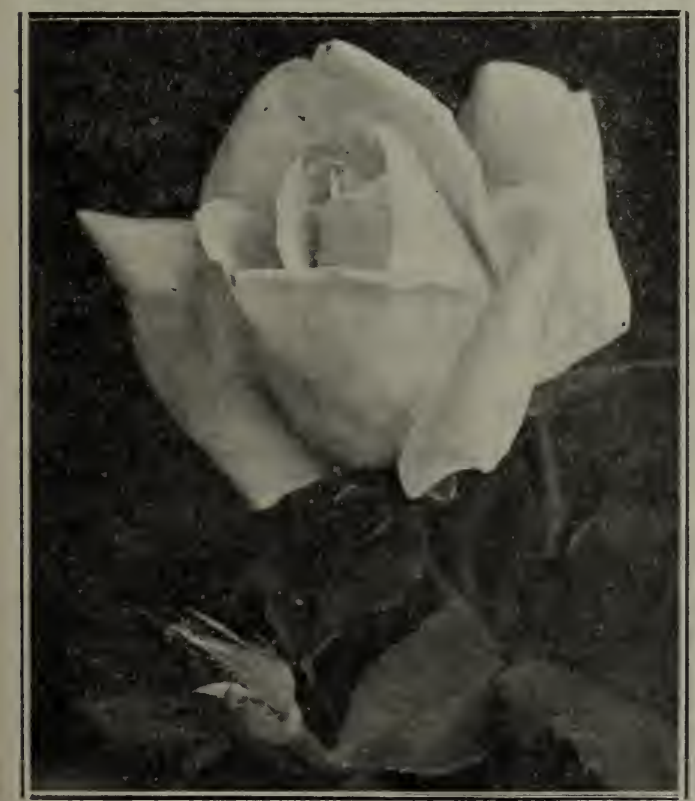

SAFRANO. (T.) Bright apricot yellow; tinged orange and fawn. Valued highly for its beautiful buds. Very profuse in bloom and deliciously tea scented. Each, $75 \mathrm{c}$.

SOLEIL D'OR (Golden Sun). (A. B.). The first of a new type and from which the wonderful Lyon Rose was developed. A perpetual bloomer, rohust grower, brownish wood, foliage beautiful bright green and scented. Flowers very double, most beautiful when full blown, a superb color, varying from gold and orange yellow to reddish gold and shaded with nasturtium red. Delightfully fragrant. Each, 75c.

SUNBURST. (H. T.). Deep yellow with nrange yellow center; large, full and beautifully formed flowers produced in great profusion. Very beautiful and the best of all Tea Roses. Each. \$1.00.

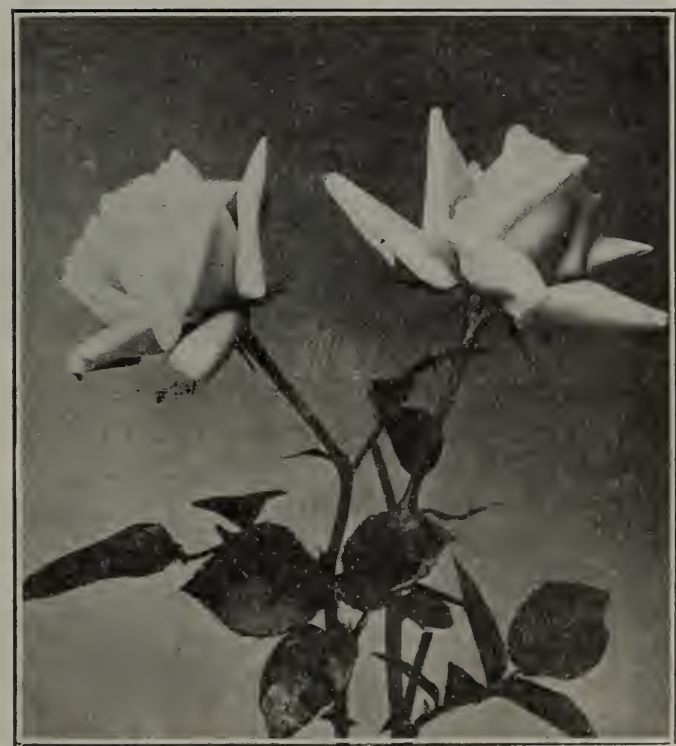

WHITE SHADES

AUGUSTINE (Guinoisseau; White Ia France). (H. T.) Pure white, shading to a center of light rose. Each, $75 \mathrm{c}$.

BESSIE BROWN (Hybrid Tea). Color, cream white, sometimes faintly flushed pink; flowers large and of shell shape. Free blooming and sweet scented. Choice two-year-old bushes, 75c.

BRITISF QUEEN (MCGredy). (H. T.). White, of pure color, in the bud stage it shoms a slight flush, which lisappears as the bloom opens; flowcrs large, of fine form, growth rigorous and hranching. very floriferous and sweetly fragrant. Each. $\$ 1.00$.

FLORENCE PEMBERTON. (H. T.). Alex, Dickson, 1903). Creamy-thite suffused pink; large. full, perfcet in form with very high pointed center; very fine. Goll Medal, N. P. S. Each, 75 c. 


\section{White Shades--Contd.}

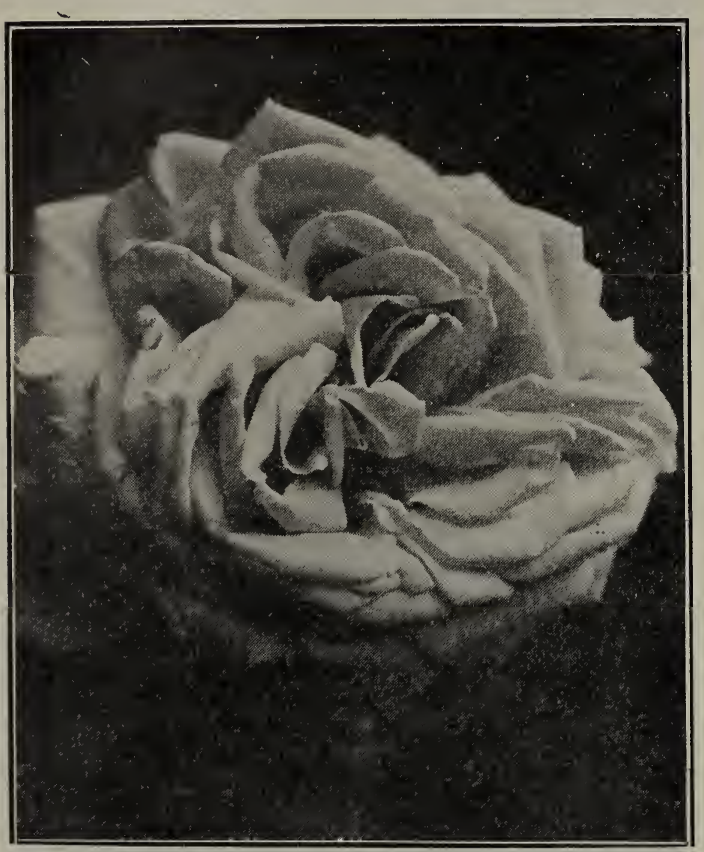

FRAU KARI DRUSCHKI OR SNOW QUEFN. (F. P.). There never has and we doubt if there ever will be a pure white rose that will excel this, the queen of all white roses. Each, $75 \mathrm{c}$.

GIORIE IYONNAISE.(F. T.). White, tinted yellow; large, full of good shape; very free, distinct and pleasing. Each, $75 \mathrm{c}$.

KAISERIN AUGUSTA VICTORIA. (T.). A strong vigorous grower, producing buds and flowers of enormous size. Color, pure white. We have no hesitancy in saying that this Rose is unequaled by any other variety of its color. Each, $75 \mathrm{c}$.

MRS. DAVIS MCKFE. A perfect white Rose, resembling Kaiserin A. Victoria. Buds more pointed and open, more perfect; a grand bloomer. Each, $75 \mathrm{c}$.
WHITE IMAMLAN COCHET. (T.). A splendid Rose; has all the good qualities of Maman Cochet but is white, equally large and fragrant, hardy and productive. One of the very best white everblooming Roses for bedding. Each. $75 \mathrm{c}$.

\section{Standard Tree Roses}

Description same as the Bush Roses

PINK SHADES

Madam Caroline Testout

Madam Abel Chatenay

RED SHADES

General Jacqueminot

Hugh Dickson

J. B. Clark

Ulrich Brunner

WHITE

Frau Karl Druschki

YELLOW

Celeine Forester

Wm. Allen Richardson

Le Progress

Stock on all varieties limited

Price, Each $\$ 2.50 \$ 3.00$

\section{CLIMBING ROSES}

Of all the plants which Nature gives to man, perhaps there are none that add more to the grace and beauty of the house and garden than the Climbers.

How many an ugly wall and unsightly building has been made attractive by a quick-growing flowering vine, and stately gardens made into veritable places of enchantment by Wisteria and Jasmine covered arbors and pergolas?

Much more artistic to the beauty-loving eye is the little Rose-covered cottage than the cold, forbidding "stone front" unadorned and unbeautiful.

They are the joy of the landscape gardener and the merest amateur alike and it is impossible to obtain anything but a graceful effect with them, for they will arrange themselves, if not otherwise disposed of, wherever they are placed, and the result is invariably a bower of luxuriant beauty.

They have done more in The City Beautiful Movement that is sweeping over the country than can be easily estimated, and there are few neighborhoods that are not afflicted with one or more "eye-sores" that need the charitable covering that a beautiful vine can give. 


\section{PINK SHADES}

BELIE STEBRECHT (H. T.) A true, solid pink of the richest shade, a rare color. The flowers are sweetly perfumed, and large, beautifully formed, of long, tapering shape, with high center, and when half blown the petals reflex in a graceful manner. A hardy, vigorous climber. Each, graceful manner. A hardy, vigorous climber, each, 75 c.

CIIMBING CECII BRUNNER (POTY). Strong rampant climber, ever-hlooming clusters of pretty pink flowers, especially beautiful in bud. A gem among climbing roses.

CIIMABING PAPA GONTIER. (H. T.). A "native sport" from the favorite bush "Papa Gontier." Each, 75c.

CrIMBING TrStoUT. (H. T.). Will do as well as the regular Testout, the one that everybody knows and has. Each, $75 \mathrm{c}$

DOROTHY PERKINS (POIY). This bautiful new Rambler is one of the finest pillar Roses. Its growth in a single season is wonderful. The foliage is glossy, green, the blossoms grow in immense clusters of 15 to 30 , very double, crinkled, of shell pink color and possess very lasting qualities. Buds are very pretty, plants extremely hardy. Must be given plenty of room when planted, each, $75 \mathrm{c}$.

TAUSENDSCHON (POTY). A wonderful new climber-very large single pink. Over three inches across. Free bloomer and a very hardy Rose. Each, 75c.

CLIMLBING AMERICAN BEAUTY. Its name is somewhat misleading, but it is one of the best climbing Roses; a strong, healthy, vigorous grower, frequently making shoots from 10 to 12 feet long, and good-sized flowers for a climbing Rose that blooms so freely; color a pleasing rose-pink, of splendid form, good substance.

\section{RED}

CIIMBING ITBERTY. Deep red; same as the well known Tea Rose; a strong climber and a fine bloomer. Each, $75 \mathrm{c}$.

CRIMSON RAMBLER. Since the introduction of the Crimson Rambler, in 1894, this class of Roses has continued to gain in popularity. Many splendid new varieties, both in single and doubleflowering forms, have been added during the past offer on this and the following two pages, each, $75 \mathrm{c}$.
HIAWATHA. Distinctly different from other Ramblers. Its small flowers, deep ruby crimson, accentuated by a white eye, are uniquely borne in long trails of 40 to 50 blooms. This variety is very popular for training on fences, not only as a covering for the fence, but because it is really one of the prettiest Roses of its kind. Each, $75 \mathrm{c}$.

REINE MARIE HENRIETTA. (T.). A strong vigorous grower, flowers large, full and of fine form; color, glowing crimson, elegantly shaded. One of the best climbers. Each, 75c.

RICHMOND. (H. T.) The most vivid of everblooming red roses, buds and flowers of the most perfect and desirable form. The best of its color. Each, $75 \mathrm{c}$.

\section{WHITE}

CIIMBING KAISERTY (Mrs. Robert Peary) This is, without doubt, the grandest of all white climbing Roses. It is the first and only pure white, hardy, ever-blooming climbing Rose. Each, 75c. ,

DOCTOR VAN FIFET. One of the newer type of climbers which combines absolute hardiness with flowers large as the tender sorts of Tea and Noisette class. This variety shows a mass of beautiful clustered buds, which open out into large, shapely flowers; delicate flesh white. An admirable cutting variety with stems 12 to 18 inches long. Each, $75 \mathrm{c}$.

SIIVIR MOON. Different from all other roses, with beautiful semi-double flowers four and a half inches and over in diameter; pure white in color, petals of great substance, beaut1fully cupped, forming a Clematis-like flower. The large bunch of yellow stamens in the centre adds to its attractiveness. Each, $\$ 1.00$.

\section{YELLOW}

SHOWRR OF GOID. Each, $75 \mathrm{c}$.

CIOTH OF GOID. Each, $75 \mathrm{c}$.

GIOIRE DE DIJON. An old favorite; flowers blush with salmon shadings; a fine climber for a sheltered wall. Each, $75 \mathrm{c}$.

MARESCHAI NEIL. A magnificent deep golden yellow variety; so famous as to need no description; grown the world over for its immense yellow flowers; the finest rose of its color in existence. Each, $\$ 1.00$.

REV. DE OR, Or CIIMBING SAFRANO. Símilar flower to Safrano. Each, $75 \mathrm{c}$.

W. A. RICHARDSON. A peculiar shade of orange yellow. Each, 75c. 


\section{Cut Flower Department}

\section{Funeral Designs}

We have for many jears given this branch of our business special attention, having at all times a skillea artist devoting his time to the making up of set pieces. Any special design or society emblem can be made by us on short notice.

We prefer to forward cut flowers by express, as they do not receive the rough handling that is in practice with postoffice employees. Orders by mail, telegraph or long-distance telephone will receive prompt attention.

The following prices prevail during the greater part of the year:

ROSES-Pink, white, red. Per doz., $\$ 1.00$ to $\$ 4.00$.

CARNATIONS-Pink, red, white. Per doz., $\$ 1.00 .1 .50$

CHRYSANTHEMUMS (Oct.-Nov.)-Selected flowers. Per doz., $\$ 1.00$ to $\$ 6.00$.

EASTER LILIES (Jan. to May)-Per doz., $\$ 2.50$ to $\$ 5.00$.

VIOLETS - In season.

BRIDES' and BRIDESMAIDS' BOQUETS, $\$ 3.00$ to $\$ 8.00$ each

We make a special SPRAY for $\$ 1.50$ from the best of the flowers which are in season combined with suitable greens. A splendid value for the money.

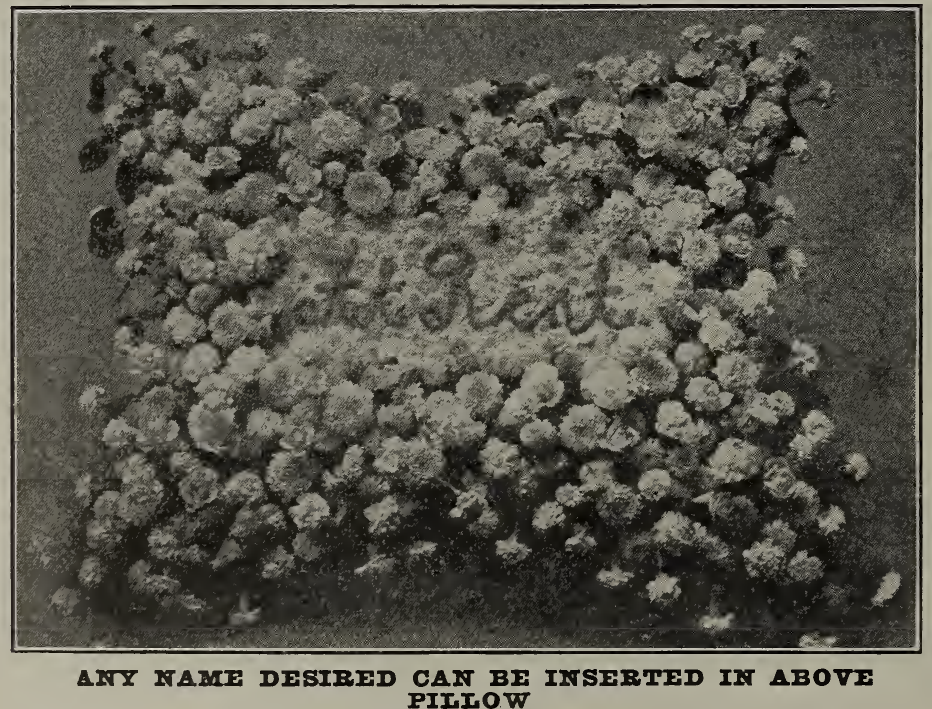

ABOVE PRICES INCLUDE PACKING, BUT NOT EXPRESS CHARGES 


\section{HARDY PERENNIALS AND HERBACEOUS PLANTS}

Achillea, the pearl white everlasting. Each, $25 \mathrm{c}$. Alyssum, Saxatile, border plant, jellow. Each, $25 \mathrm{c}$

Alyssum, Little Gem or Carpet of Snow. Doz., $50 \mathrm{c}$.

Anchusa, Italica, deep blue. Each, 2 5.

Anemone, Japonica. Each, 25c.

Antirrhinum (Snapdragon) various colors, large plants. Each, 25c.

Aquilegia, (Columbine), long spurred. Each, $25 \mathrm{c}$.

Arabis Alpina, (Snow in the Mountain) Dozen, $75 \mathrm{c}$.

Aster (Michaelmas Daisy). Each, 25c.

Bleeding Heart, (Dielytra Spectabis). Each, $25 \mathrm{c}$. Campanula, medium, Canterberry bells, various colors. Each, 25c.

Campanula, Calycanthema, (Cup and Saucer). Each, 2 5̃c.

Cerastium, Tementosum (Snow in Summer). Each, $25 \mathrm{c}$.

Chrysanthemum, hardy varieties. Each, $25 \mathrm{c}$. Coreopsis, Ianceolata, Grandiflora. Each, $25 \mathrm{c}$. Daisies, Shasta. Each, $25 \mathrm{c}$.

Daisies, Burbank Alaska. Each, 2 sc.

Delphinium, (Perennial Iarkspur), in variety. Each, 25̄c.

Dianthus, (garden pinks), Mrs. Sinkin's large white. Dozen, $\$ 1.00$.

Dianthus, (garden pinks),pink. Dozen, $\$ 1.00^{\circ}$

Dianthus, (garden pinks), mixed. Dozen, $\$ 1.00$.

Digitalis, (Foxglove); various colors. Dozen, $20 \mathrm{c}$.

Doronicum, Excelsum. Dozen, $25 \mathrm{c}$.

Echinops, (Globe thistle). Each, 25cll

Statice Iatifola (Sea Lavender). Each, $25 \mathrm{c}$.

Tritoma, Pfitzeri, (Red Hot Poker). Each, $50 \mathrm{c}$.

viola, Fellow Prince. Dozen \$1.25. violets, California, single. Dozen, $\$ 1.00$.

Violets, California, double. Dozen, $\$ 1.00$.

Wallflower, blood red. Each, 20c; Dozen, $\$ 2.00$

Eryngium, Alpinum (Sea Holly). Each, $25 \mathrm{c}$.

Geum, Mrs. Bradshaw . Each, 25̃c. $2 \check{c}$

Gypsophila Paniculata (Baby Breath). Each,

Helianthus (Sunflower) Multiflorous Plenus. Each, 25c.

Helianthus (Sunflower), Miss Mellish. Each, $25 \mathrm{c}$.

Helliborus, Nigra, Christmas Rose. Each, $50 \mathrm{c}$.

Hemorocallis Aurantiaca (day lily). Each, $35 \mathrm{c}$. Heuchera Sanquinea, (Coral Bells). Each, $25 \mathrm{c}$. Hollyhock, double, in separate colors. Each, ,0c.

Iris Germanica, assorted colors. Each, $25 \mathrm{c}$.

Iberis, Gibraltarica, hardy candytuft. Each, $25 \mathrm{c}$. Iris, Kaempferi, Japanese assorted colors. Each, $20 \mathrm{c}$.

Iilium, Candidum (Madonna Lily). Each, 25c.

Iavender.. Each, 50c.

Iily of the Valley. Dozen, 90c; Per $100 \$ 6.00$.

Ininum Perenne, blue. Each, $25 \mathrm{c}$.

Iobelia, cardinals. Each, $25 \mathrm{c}$.

Montbretia, mixed. Dozen, $\$ 1.00$.

Papaver, Orientalis, oriental poppy. Each, $20 \mathrm{c}$. Phlox, subulata, dwarf. Each, 25c.

Phlox, hardy, red, white and pink. Each, 2jc.

Primrcse, yellow. Each, 20c.

Polyanthus, various colors. Each, 20c.

Pyrethrum, Hybridum, various colors. Each, $35 \mathrm{c}$. Rudbeckia, golden glow. Each, $25 \mathrm{c}$.

Scabious, Caucasica, blue and white. Each, $25 \mathrm{c}$. Sweet William, (Auricula Eye). Each, 20c.

\section{ORNAMENTAL GRASSES AND BAMBOOS}

Adams Needle, (Fucca Filamentosa). Each, 50c to $\$ 1.50$.

Plume Grass, green, white, midrib. Each, 50c.

Pampas Grass. Each, $\$ 1.00$ to $\$ 1.50$. $50 \mathrm{c}$.

Ribbon Grass, striped white and green. Each, Golden Bamboo, rellowish stems, leaves green. Each, $\$ 1.00$ to $\$ 1.50$.

\section{PEONIES}

Festiva Maxima, very large, pure white. Each, $50 \mathrm{c}$ an'? $\overline{5} \mathrm{c}$.

Fragrans, deep rose. Each, $50 \mathrm{c}$ and $75 \mathrm{c}$.

Iouis Van Houtte, bright violet red. Each, $50 \mathrm{c}$ and $75 \mathrm{c}$.
Iais, pink sulphur center. Each, 50c and $75 \mathrm{c}$. Officinalis, Alba, pure white. Each, $50 \mathrm{c}$ and $75 \mathrm{c}$. officinalis, Rosea. large, pure pink. Each, $50 \mathrm{c}$ and $75 \mathrm{c}$.

Officinalis. Rubra, crimson. Each, $50 \mathrm{c}$ and $75 \mathrm{c}$. 


Our seeds insure you a
prolifio orop WOODREF

\section{Hardy Ornamental Trees, Shrubs and Vines}

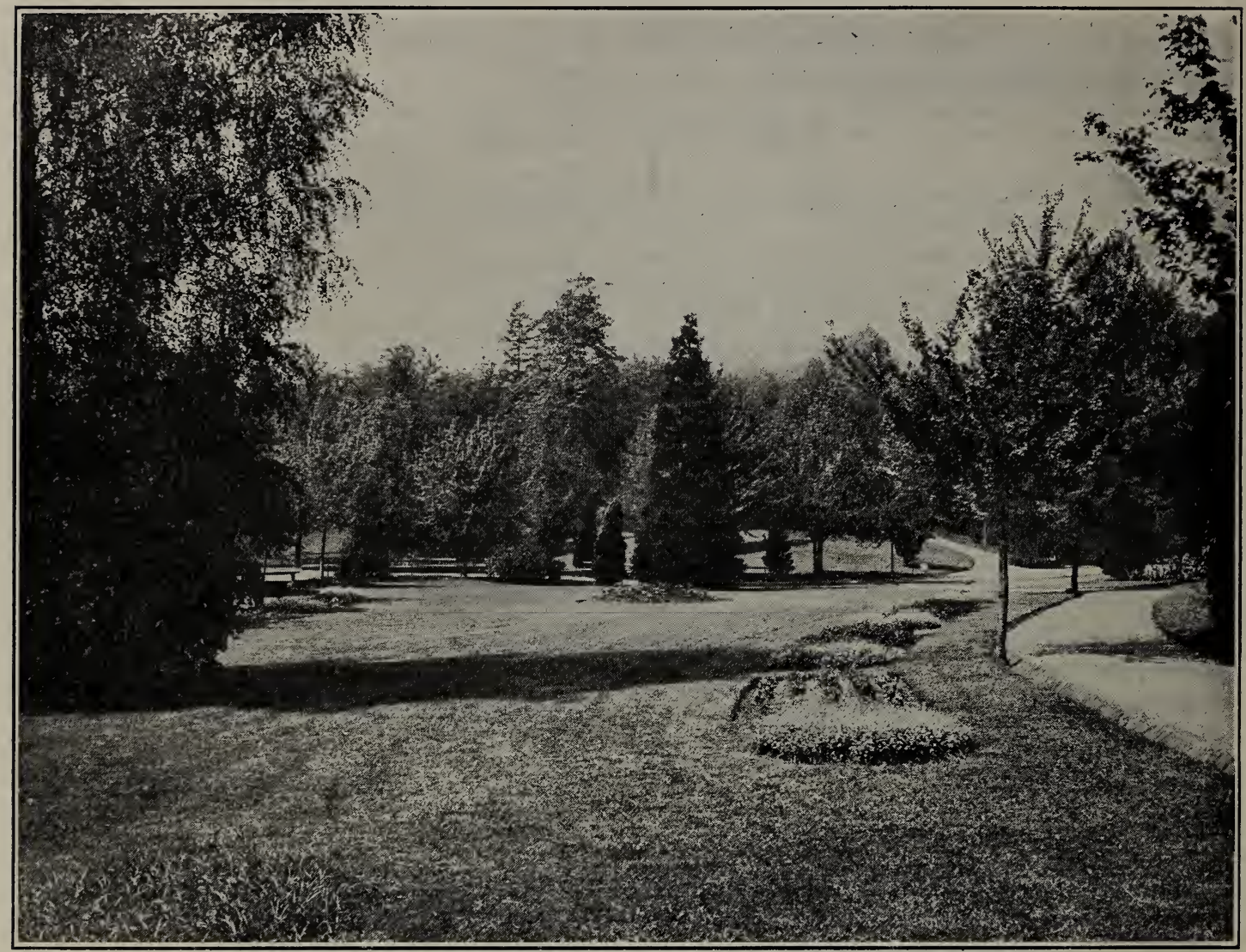

\section{HARDY CLIMBERS}

AMPEIOPSIS QUINQUEFOIIA. Woodbine or Virginia Creeper. Deeply cut leaves which turn to a beautiful crimson in the fall: fine for covering trees, walls, etc. Each, $75 \mathrm{c}$ to $\$ 1.00$.

Englemanni. Similar to Veitchi but with denser foliage. Each, $50 \mathrm{c}$ to $75 \mathrm{c}$.

Veitchi. Boston Ivy. This is one of the best climbers for covering walls. Foliage bright green in summer, changing to crimson in the fall. Each, $75 \mathrm{c}$ to $\$ 1.00$.

CIFMATIS. This superb family of hardy climbers are unsurpassed for pillars or trellises. Jackmani. Purple. Each, $75 \mathrm{c}$ to $\$ 1.00$. Henryi. Creamy white. Each, $75 \mathrm{c}$ to $\$ 1.00$.

Edward Andre. Crimson red. Each, $75 \mathrm{c}$ to $\$ 1.00$.

Duchess of Fdinburgh. Double pure white. Each, $\$ 1.00$.

Paniculata. Sweet scented Japanese Clematis. Bears immense sheets of pure white fragrant flowers. Each, . 75.c.

FIGIISE IVY. This is considered a house plant in many parts of the country, but it thrives in this locality and is extensively used for covering fences, dead trees, etc. Each $25 \mathrm{c}$ to $50 \mathrm{c}$.
EUONYMUS REPENS ON JAPANFSE TVY. Green. Each, 50c to $\$ 2.00$.

Variegated. Each, 50c to $\$ 2.00$.

HONEYSUCKIF. The delightful fragrance of the flowers of this vine make it one of the most ponular in the world.

Belgian or Evergreen. Each, $75 \mathrm{c}$ to $\$ 1.00$.

Sweet Scented. Each, $75 \mathrm{c}$ to $\$ 1.00$.

Golden Japanese. Each, 75ic to $\$ 1.00$.

JAsmurrs. Favorite climbers for sheltered positions.

Nudiflorium. Fragrant vellow flowers; blooms in February out of doors. Each, $\$ 1.00$.

Officinalis. Pure white, fragrant flowers. Each, $\$ 1.00$.

wISTARIAs. One of the best hardy climbers. Of rapid growth, when in bloom it presents a magnificent appearance.

Multijuga. A Japanese variety bearing purple flowers. Each, $\$ 1.00$ to $\$ 1.50$ and $\$ 2.00$.

Multijuga. Same as above but bearing white flowers. Each, $\$ .100$ to $\$ 1.50$ and $\$ 2.00$. 


\section{FLOWERING SHRUBS}

AIIHEA Or ROSE OF SEAROT. Blooms late n the summer, with a profusion of large, brightly colored flowers. Grown in standard form, they attain 10 or $12 \mathrm{ft}$. in height; planted close and occasionally pruned, they are attractive and serviceable as hedges. Each, $\$ 1.00$ to $\$ 1.50$.

ATMOND. Pink, double flowering. Usually in full bloom before leaves appear. Each, $\$ 1.00$ to $\$ 2.00$.

AZATIAS. These are among the most gorgeous of all the shrubs. They are resplendent with bright colors early in the spring.

Red, 8 to 10 in., each, $\$ 1.00 ; 10$ to 12 in., each, $\$ 1.75$.

White, 18 in to $2 \mathrm{ft}$., each, $\$ 2.50$.

Pink, 2 to $3 \mathrm{ft}$., each, $\$ 3.00$.

Double I avender, 18 in., each, $\$ 2.00$.

Mollis. Each, $\$ 1.25$ to $\$ 2.50$.

BARBERRY (Berberis). Highly ornamental shrubs that are hardy everywhere. They bear masses of white, yellow or orange flowers and berries that are persistent throughout the winter. Invaluable for hedges.

Thunbergi. Dwarf and of dense growth; yellow flowers followed by scarlet berries. Each, $\$ 1.00$ to $\$ 1.50$.

Purpurea. Foliage a beautiful deep purple all the year. Fach, $\$ 1.00$

vulgaris. Bright green foliage, yellow flowers and red berries. Each, $\$ 1.0 j$ to $\$ 1.50$.

BUDDIFIA or BUTTERTYY BUSE. One of the handsomest and most admired of all shrubs. Blooms abundantly with long spikes of fragrant blue flowers. Each, $\$ 1.00$.

BROOM. A highly ornamental shrub, peculiarIy adapted to this climate. Does well in poor soil.

Vulgaris. Yellow. Each, 50c.

Alba. White. Each, $75 \mathrm{c}$.

Compacta. Each, $75 \mathrm{c}$.

Andriana. Ref. $75 \mathrm{c}$

Spanish. Yellow, blooms all summer. Each, $\$ 1.25$.

CHFRrY. Japanese fowering. Double large trees. Each, $\$ 1.50$ to $\$ 3.50$.

CRAB. Bechtel's flowering. Pink, a handsome lawn tree. Each, $\$ 1.50$ to $\$ 2.00$.

CAIYCANTHUS. Carolina Allspice. A unique shrub of quick rrowth: dark red flowers of spicy fragrance. Each, $75 \mathrm{c}$ to $\$ 1.00$.

DESMODIUM PFNDUIIIORIUM. A shapely shrub 2 to $4 \mathrm{ft}$. high; literally covered in early autumn with long racemes of magenta colored flowers. Each, $\$ 1.00$.

DOGWOOD. The shrubby dogwoods are mainly valuable for the brilliancy of their barks and berries, and the handsome variegation of their foliage.

Silver Ieaf. Each, $\$ 1.00$.

Golden Ieaf. Each, $\$ 1.00$.

Golden Twig. Each, $\$ 1.00$.

Red Twig. Each, $\$ 1.00$.

DEUTZIAS. Valuable shrubs that vary considerably in height and habit. Flowers are dainty bell or tassel-shaped, borne thickly in wreaths along the branches.

Gracilis. Dwarf, densely bushy, pure white flowers. Each, $75 \mathrm{c}$ to $\$ 1.50$.
Pride of Rochester. Grows 6 to $8 \mathrm{ft}$ high, $\$ 1.50$.

flowers double, pure white. Each, $75 \mathrm{c}$ to

FORSYTHIA or GOIDEN BFII. A splendid shrub, grows 8 to $10 \mathrm{ft}$. tall. Is covered with bright golden flowers early in the spring, before the leaves appear. Each, $\$ 1.00$.

HORSE CHESTNUT (Dwarf). A broad round bush of deep green, beautiful with upright spikes of white flowers. Each, $\$ 1.25$.

\section{HYDRATGEAS.}

Aborescens Grandiflora. A splendid summer flowering, hardy shrub. Blooms in great profusion during July and August, the flowers being similar to the familiar "Snow Ball." Each, 75c to $\$ 1.00$.

Paniculata Grandiflora. This familiar shrub comes into prominence during August when it is laden with large masses of white plumes. Each, $75 \mathrm{c}$ to $\$ 1.00$.

Fortensia. Pink. Eách, $\$ 1.00$ to $\$ 1.50$

Fortensia. Blue. Each, $\$ 1.00$ to $\$ 1.50$.

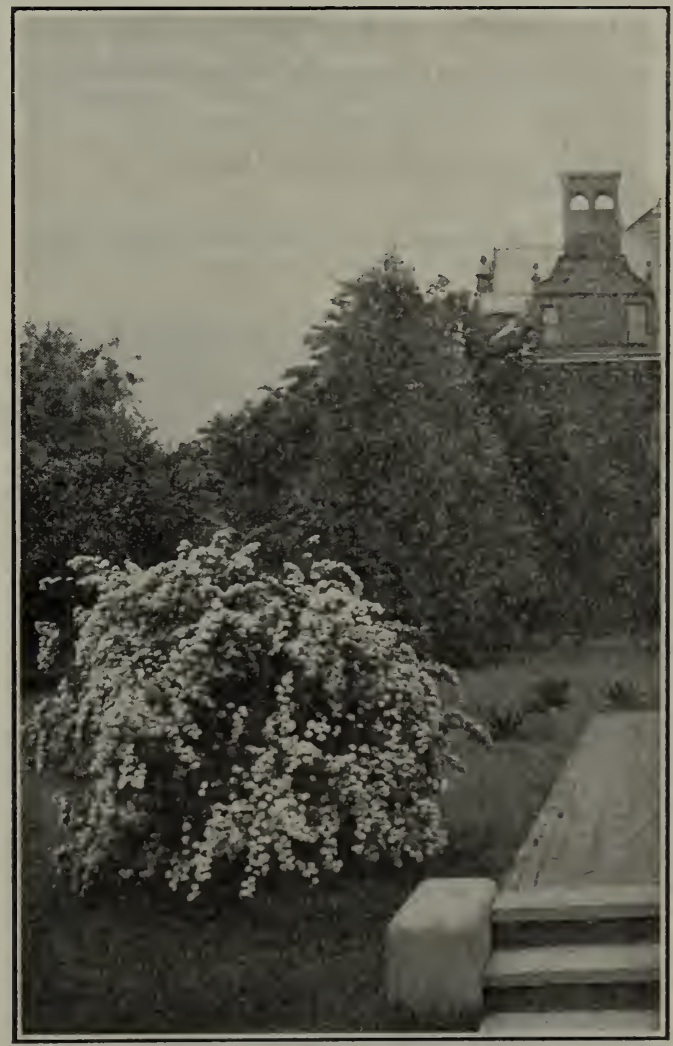

JAPAN SFOWBATI.

JAPANESE SNOWBATI. 6 to $8 \mathrm{ft}$ high, with purple tinted foliage. In June they are a solid mass of white bloom. Each, $\$ 1.00$ to $\$ 2.00$. 


\section{FLOWERING SHRUBS -Continued}

JAPANESE OUINCE. Bushy, dense growth, with protecting thorns. Blooms early in spring, and is covered with dazzling scarlet flowers. Each, $75 \mathrm{c}$ to $\$ 1.00$.

IIIACS. The most popular of the old-time gaden shrubs, whose delicate flowers with their tender fragrance never fail to please.

Common Purple. Each, $75 \mathrm{c}$ to $\$ 1.5$ J.

Common white. Each, $75 \mathrm{c}$ to $\$ 1.50$

Grafted Varieties-

Mme Iemoine. Double white 3 to $4 \mathrm{ft}$. only. Each, \$1.75.

Marie Ie Graye. Single, pure white. Each, $\$ 1.75$.

Mme. Casimir Perier. Double, cream, each, $\$ 1.75$.

Souvenir de Iudwig Spaeth. Dark red. Each, $\$ 1.75$.

Charles X. (Reddish). Purple. Each, \$1.7.5.

JAPANESE IIUACS. White and purple. Each, $\$ 1.00$

IABURNUM ON GOIDEN CHAIN. This charming small tree is of picturesquely irregular growth and with its glossy leaves and long racemes of bright yellow flowers presents a striking appearance. Each, $\$ 1.25$ to $\$ 2.00$.

PFACF (Double rlowering). A very beautiful, small tree; at blossoming time every twig is covered with beautifully formed flowers. Each, $\$ 1.75$.

PHILADEIPHUS (Syringia or Mock Orange). One of the best and most popular of the old shrubs. The taller growing sorts are largely used for hedges.

Aureus or Golden Syringia. Each, $\$ 1.00$.

Grandiflorus. Each, $75 \mathrm{c}$.

Nivalis. Each, $75 \mathrm{c}$.

ROBINIA HISPIDIA Or DWARF PINK IOcosT. Bears beautiful pink flowers all summer. Lach, $\$ 1.25$.

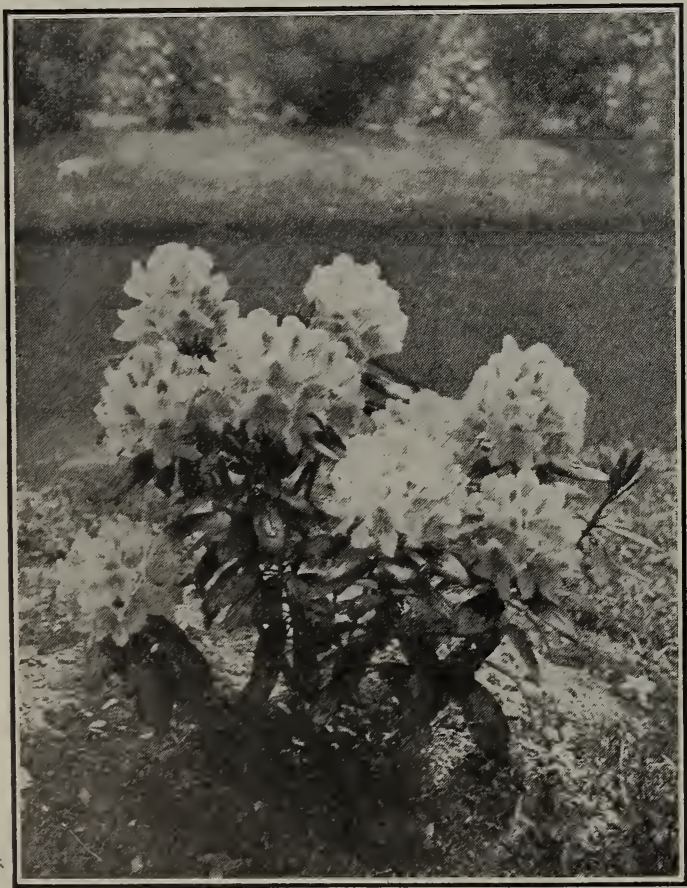

RHODODENDRON
RHODODENDRONS. There is no shrub in nature that can compare with the Rhododendrons. During June and July they produce an abundance of flowers and the many different colors permit groupings in large beds that are wonderful in effect. Choice grafted plants, each, from $\$ 3.50$ up.

RHODOTYPUS KERRIOIDES. An attractive shrub 3 to $6 \mathrm{ft}$. high with yellowish green foliage and large, single white flowers, followed by black berries which last all winter. Each, $75 \mathrm{c}$.

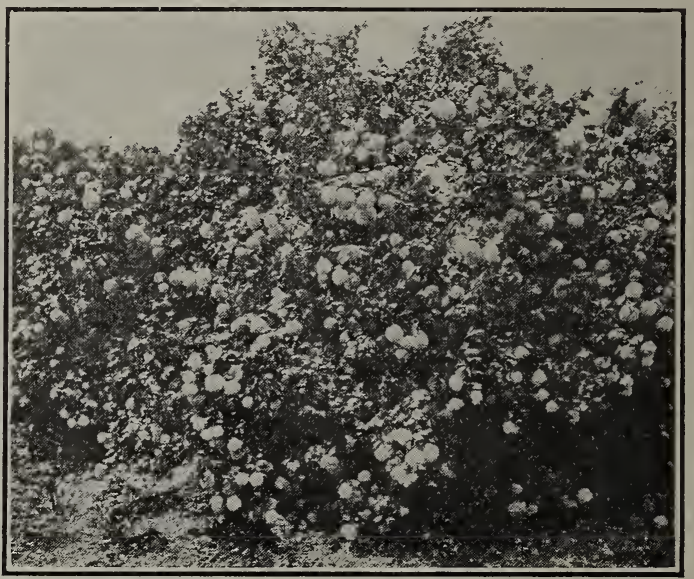

SNOWBALL

SNOWBAII (Virburnum).

Sterilis. The common Snowball which helps out so bravely on Decoration Day with its white balls of bloom. Each, $\$ 1.00$.

Opulus. High Bush Cranberry. The flowers are followed by red berries which cling to the branches well into the winter. Each, $\$ 1.00$.

Plicatum. Japanese Snowball. Grow 6 to $8 \mathrm{ft}$. high with purple tinted foliage. In June they are a solid mass of white bloom. Each, $\$ 1.00$.

RHUS COTINUS. Purple Fringe or Smoke Tree. A conspicuous shrub overhung in midsummer by masses of light, mist-like flowers which at a distance have the appearance of smoke. Each, $\$ 1.25$.

SAMBUCUS. Elder Berry. The elders, while attractive in flowers and fruit, are chiefly grown for their beautiful foliage.

Silver Ieaf. Each, 75c.

Golden Ieaf. Each, $75 \mathrm{c}$

Cut Ieaf. Each, $75 \mathrm{c}$.

\section{SPIREAS.}

Arguta Multiflora. A splendid shrub 3 to 5 ft. high. Early in May the branches are a mass of white flowers. Each, $75 \mathrm{c}$ to $\$ 1.00$.

Anthony waterer. A dwarf, bushy type with rosy crimson flowers. Fach 75c and $\$ 1.00$

Prunifolia fl. pl. (Bridal Wreath). Plum leaved foliage; tall growing, but will prune to any desired height. Blooms early, and is very effective with its long gracefully curving branches covered their whole length with small, double white flowers. 2 to $3 \mathrm{ft}$. $75 \mathrm{c}$ and $\$ 1.00$.

van Foutti. The grandest of all the Spireas. Completely covered with pure white bloom early in June. Each, $75 \mathrm{c}$ to $\$ 1.00$. 


\section{HARDY FLOWERING SHRUBS}

SYMPHORICARPUS. Highly valued for use in shaded situations and for the beauty of their bright, persistent fruits.

Racemosus. Snowberry. Rose colored flowers followed by large clusters of milkwhite fruit which last well into the winter. Each, $75 \mathrm{c}$.

vulgaris. Indian Currant. Similar to the Snowberry except that the berries are red and are borne in thick ropes about the stems. Each, 75c.

TAMARIX. Strong, slender, tall-growing shrubs with feathery foliage and delicate flowers, borne profusely on gracefully bending branches. Each, $\$ 1.00$ to $\$ 2.00$.
SUMAC.

Rhus Copallina. Tall growing with glossy foliage. Blooms late; flowers large, greenish-white followed by large, red fruit. Foliage colors wonderfully in the fall. Each, $75 \mathrm{c}$.

Rhus Typhina Iaciniata. Delicate, fern-like foliage with brilliant red fruit in the fall. Each, $\$ 1.00$.

WEIGELA. Beautiful shrubs that bloom in June and July. Blooms in great profusion, in fact, the flowers almost entirely hide the foliago. Candida. White. Each, 75c.

Eva Rathke. Deep red. Each, $\$ 1.00$ to $\$ 1.50$. variegated. Each, $75 \mathrm{c}$ to $\$ 1.00$.

\section{EVERGREEN SHRUBS}

AUCUBA. A palm-like plant with broad, shiny green leaves thickly spotted with gold. Variegated and green varieties. 12 in., each $\$ 1.50 ; 1 \frac{1}{2}$ to $2 \mathrm{ft}$., each, $\$ 3.00 ; 2$ to $3 \mathrm{ft}$., $\$ 5.03$.

BOXWOOD. Most extensively used of the Evergreen shrubs, for indoor, porch and lawn decoration

Plants suitable for hedging. Each, $25 \mathrm{c} 4 \mathrm{oz}$.

Untrimmed. Each, $\$ 1.00$ to $\$ 2.00$.

Ball-shaped. Each, $\$ 2.50$ to $\$ 10.00$

Pyramidal. Each, $\$ 2.50$ to $\$ 10.00$.

COTONBASTER. A dwarf trailing evergreen which during the autumn and winter is covered with brilliant berries. Splendid for rockeries.

Horozantalis. Red berries. $\bar{\jmath} \mathrm{c}$ $\$ 1.00$.

Francheti Orange. Yellow berries. Each,
HEATHER CAIIUNA. Low evergreen shrubs cultivated chiefly for their bright, rosy-pink flowers, appearing late in summer. A number of varieties. Each, $50 \mathrm{c}, \$ 1.00$, and $\$ 2.00$.

JASMINE (Bush). A beautiful evergreen shrub, bearing great numbers of waxy, pure white flowers, exquisitely scented. Each, \$1.00.

IAUREI. English. $\$ 1.00$ to $\$ 5.00 ;$ standard, from $\$ 4.50$ to $\$ 7.50$.

IAURUSTINUS. Each, $\$ 1.00$ to $\$ 2.50$

PRIVIT. Besides being one of our best hedge plants, the various species form interesting groups on the la $\pi^{n} \mathrm{n}$. The flowers are fragrant. $1 \mathrm{ft} ., \$ 5.00$ per $100 ; 11 / 2$ to $2 \mathrm{ft}$., $\$ 7.50$ per $100 ; 2$ to $3 \mathrm{ft}$. $\$ 10.00$ per 100

Golden. $1 \mathrm{ft}$, $50 \mathrm{c}$; 2 to $3 \mathrm{ft}$, $\$ 1.50$.

VERONICA. A silver-leaved, evergreen shrub with long, feathery foliage; very effective in groups or rockery.

Buxifolia. Dwarf. Each, $30 \mathrm{c}$ and $50 \mathrm{c}$.

Traversi. Tall. Each, $50 \mathrm{c}$ to $\$ 2.00$.

\section{SHADE AND ORNAMENTAL TREES}

AIIAMTHUS (Tree of Heaven). Of very rapid growth. Thrives in city lots where many other trees will perish. 6 to $8 \mathrm{ft}$, each, $\$ 1.25$.

ALDER (Cut reaved). A very graceful tree for the la $\pi_{n}$, a quick grower. 10 feet, $\$ 1.25$.

ASH (Mountain). A large spreading tree of rapid growth. $\$ 1.50$ to $\$ 2.00$.

BEECH (Purple Ieaved). A beautiful mediumsized tree for the lawn. 7 to $8 \mathrm{ft}$. Each, $\$ 2.50$.

CATAIPA (Speciosa). Very ornamental and one of the most rapid growers. Each, $\$ 1.50$ to $\$ 2.00$.

Bungei. Very hardy and with its umbrellashaped top makes a splendid tree for the lawn. Each, $\$ 2.50$ to $\$ 5.00$.

ELM (American). A large and noble tree, unequaled for park or street planting. S to $10 \mathrm{ft}$ Each. $\$ 1.50$ to $\$ 2.50$.

Red. 6 to $7 \mathrm{ft}$., each $\$ 1.25$; extra large, $\$ 2.00$ Pink. 6 to $\tau$ ft., Extra large. Each, $\$ 2.00$ white. 6 to $7 \mathrm{ft}$, each, $\$ 1.50$.

HAWTHORN. Very desirable for the lawn both for their foliage and flowers.

Red, 6 to $7 \mathrm{ft}$, each, $\$ 1.50$ to $\$ 3.00$

Pink. 6 to $7 \mathrm{ft}$ each $\$ 1.50$ to $\$ 3.0$.

White. 6 to $7 \mathrm{ft}$., each, $\$ 1.50$ to $\$ 3.00$.

HORSE CHISTMUT. A very handsome tree for lawn or street planting. S to $1.3 \mathrm{ft}$.. $\$ 2.0 n$.
IINDEN (European). A pyramidal shaped tree with fragrant flowers. $\&$ to $10 \mathrm{ft}$, eacl, $\$ 1.50$ to $\$ 2.50$

Silver Ieaved. Its beautiful foliage makes it one of the finest of ornamental trees. S to $10 \mathrm{ft}$. each, $\$ 1.75$.

IOCUST (Black). A large tree of rapid growth, bears long racemes of fragrant, white flowers. $\mathrm{S}$ to $10 \mathrm{ft}$., each, $\$ 1.50$ to $\$ 2.00$.

HONEY. A large, wide-spreading tree, feathery foliage, flowers are very fragrant, long sharp thorns. \& to $10 \mathrm{ft}$., each, $\$ 1.50$ to $\$ 2.50$.

MAPLES.

Sugar or Rock Maple. The grandest of all shade trees. Of large proportions, it does well in all except damp soils. 8 to $10 \mathrm{ft}$, $\$ 1 . \overline{0} 0$ to $\$ 2.0)$

Silver. A hardy rapid-growing tree. 10 to $\mathrm{s}$ to $10 \mathrm{ft}$, each, $\$ 1.50$ to $\$ 2.00$.

Norway. A native of Europe; very desirable for láwn, park or street planting.

ft. $\$ 1.50$ to $\$ 2.00$.

POPIAR (Iombardy). Remarkable for its tall, stately form. \& to $10 \mathrm{ft.}$, each, $\$ 1.50$

Carolina. A vigorous, hardy tree of rapid srowth. S to $10 \mathrm{ft}$., each, $\$ 1.50$

PRUNUS (Pissardi or Japanese Purple Ieaved Plum). A small tree; its purplish foliage and white flowers make it a unique ornament for the la $\pi n$. \& to $10 \mathrm{ft}$., each, $\$ 2.00$. 


\section{SHADE AND ORNAMENTAL TREES}

SYCAMORE (European or Oriental Plane). A lofty wide-spreading tree with handsome foliage. 10 to $12 \mathrm{ft}$., each, $\$ 1.50$ to $\$ 2.50$.

TUIIP TREE or WHITEWOOD. A tall pyramid-shaped tree with broad gIossy leaves and tulip-shaped flowers. 8 to $10 \mathrm{ft}$., each, $\$ 2.00$.

\section{WEEPING TREES}

BIRCH (Cut Ieaved). The most beautiful of all the weeping or pendulous trees. Its graceful appearance, silvery bark and delicately cut foliage make it a singularly attractive ornament for the lawn 6 to $8 \mathrm{ft}$., each, $\$ 2.50$.

WIIIOWS, Very graceful and ornamental. A valuable tree for park or lawn. 6 to $8 \mathrm{ft}$., each, 1 to $5 \mathrm{ft}$., each $\$ 1.00$ to $\$ 5.00$.

\section{IVERGREEN TREES}

ARBOR VITAT (Chinese Golden). Very compact and regular in habit; the foliage assumes a beautiful golden tint in the spring. Choice plants, $\$ 2.00$ and $\$ 4.00$.

ARAUCARIA, IMRBRICATA (Chile Pine or Monkey Tree). Each, $\$ 2.50$ to $\$ 15.00$.

CAMIIIIA (Japonica). Very beautiful, winter flowering evergreen; the handsome, shining dark green foliage and magnificent, wax-like flowers of various colors render them indispensable for the conservatory, and are well adapted for parlor or window culture; perfectly hardy in this climate, in the open ground, but should be planted in a shady place and protected first year. We have these in three colors-double white, pink and red; $11 / 2$ to $2 \mathrm{ft}$, each, $\$ 3.00$ to $\$ 4.00$; large plants.

CYPREsS. (Lawsoniana) Erecte Viridis. 11/2 to $2 \mathrm{ft}$., $\$ 2.50$. 2 to $4 \mathrm{ft}$., $\$ 5.00$. 4 to $6 \mathrm{ft}$., $\$ 10.00$ to $\$ 15.00$.

CYPRESS (Lawsoniana). A beautiful tree, native of this state, with elegant drooping branches and very slender, feathery branchlets; 2 to $3 \mathrm{ft}$., each, $\$ 2.50 ; 4$ to $5 \mathrm{ft}$., $\$ 5.00$.
CRYPTOMIFRIA. One of the finest evergreens of Japan; of both upright and drooping habit; foliage most needle-like, end of branches soft and flexible; $\$ 2.50$ to $\$ 4.00$.

DAPENE (Odora). A very pretty early flowering shrub, producing pink flowers in March; $2 \mathrm{ft}$., each, $\$ 2.50$.

HOIIY. English. (Ilex aquifolium.) Our plants are carefully trimmed specimens and berry bearing. Each, $\$ 2.50$ to $\$ 6.00$. Fine specimens. $\$ 7.50$ to $\$ 20.00$.

GOLDFN MARGINIFD. Leaves splashed with pale green, narrow but irregular, golden edge, $\$ 2.0$ J to $\$ 5.00$.

STIVER MARGINFD. Leaves long, dark green, slightly mottled and with an irregular, narrowish silvery margin Fer ft., $\$ 2.00$

JUNIPER, COMPACTA. A dense, green, evergrowing shrub; may be trimmed into most any shape; grows about 6 to $7 \mathrm{ft}$. high; $\$ 3.50$ to $\$ 5.00$.

IrISEI. A distinct and beautiful variety of erect, dense, conical outline and upright growth; short, glaucous green foliage; $\$ 2.00$ to $\$ 5.00$.

RETINOSPORA (Plumosa Aurea). A most beautiful variety; greenish golden yellow all through the year; compact; makes the most beautiful show of any evergreen. $10 \mathrm{ft}$., $\$ 2.00, \$ 3.00$ and $\$ 5.00$.

SPRUCE (Colorado Blue). No evergreen can excel the true blue spruce. It is very hardy and will grow where other evergreens will fail. $1 \frac{1}{2} \mathrm{ft}$. to $2 \mathrm{ft}$., $\$ 2.50$ to $\$ 3.50$ choice specimens, $\$ 5.00$ and $\$ 10.00$ each.

YHW, TRISH (Texas Hibernica). Upright in form, foliage deep green; very compact; one of the most wonderful evergreens for lawns or groups. $1 \frac{1 / 2}{2}$ to $2 \mathrm{ft}$., $\$ 3.00 ; 2$ to $3 \mathrm{ft} ., \$ 5.00 ; 3$ to $4 \mathrm{ft}$., $\$ 5.00$ to $\$ 7.50$.

\section{GUARANTEE}

OUR STOCK of high grade, hardy, guarantee field-grown shrubs, plants and trees is exceptionally good this year, and we feel that we are in a better position than ever before to take care of your wants and furnish planting stock of quality which will please and give highest satisfaction. Questions as to selections of varieties and general advice upon matters horticultural will be cheerfully answered at any time.

GUARANTEE. The living of trees and shrubbery is, largely dependant upon conditions of soil weather and aftercare beyound the nurseryman's control; therefore we do not guarantee any stack to live after leaving the nursery promptly on receipt of stock order. After it is received and planted the purchaser can have no reason for complaint to the grower.

We do, however, warrant stock true to name and will replace any that may prove otherwise, or will refund the original purichase price, but will not be responsible for more than price paid for stock, and all sales are made with this understanding.

Do you know the secret of growing big crops of large, luscious fruit? To be successful you must above all things, start right. Get large, strong, healthy, standard-sized stock. This applies to small fruits, just as much as it does to Apple. Cherry, Peach. Pear. Plum Trees, etc. Our principal stocks of fruit trees, small fruits, etc., embrace only those varieties which have been well proved. and can be recommended as the best for this country now in cultivation. We cannot attempt to give complete directions on all points connected with tree planting, but simply a few hints on the more important operations. Transplanting to be considered under the following heads: 


\section{THE PREPARATION OF THE SOIL}

For fruit trees soil should be dry, either natural or made so by thorough drainage, as they will not live or thrive on a soil constantly saturated with stagnant moisture. It should also be well prepared. On new, fresh lands, manuring will be unnecessary, but on land exhausted by cropping fertilizers must be applied, either by turning in heavy crops of clover, or well decomposed manure or compost. To insure a good growth of fruit trees, land should be in as good condition as for a crop of wheat, corn or potatoes.

\section{THE PREPARATION OF THE TREES}

In regard to this important operation, there are more fatal errors committed than in any other. As a general thing trees are planted in the ground precisely as they are sent from the nursery. In moving a tree, no matter how carefully it may be done, a portion of the roots are broken and destroyed and consequently the balance that existed in the structure of the tree deranged. This must be restored by proper pruning, adapted to the size, form and condition of the tree as follows:

\section{STANDARD ORCHARD TREES}

These, as sent from the nursery, vary from 4 to 6 feet in height, with naked stems or trunks and a number of branches at the top forming a head. These branches should all be cut back to within three or four buds of their base. This lessens the demand upon the roots, and enables the remaining buds to push with vigor. Cut off smoothly all bruised or broken roots up to the sound wood. In case of older trees of extra size, the pruning must be in proportion; as a general thing it will be safe to shorten all the previous year's shoots to three or four buds at their base, and where the branches are very numerous some may be cut entirely.

STAKIIG. If trees are tall and much exposed to the wind, a stake should be planted with the tree to which it should be tied in such a manner as to avoid chafing. A piece of matting or cloth may be put between the tree and the stake.

MUICEnTG. When the tree is planted, throw around it as far as the roots extend, and a 100 t beyond, five or six inches deep, rough manure or litter. This is particularly necessary in dry ground and is highly advantageous everywhere, both in spring and fall planting. It prevents the ground from baking or cracking, and maintains an equal temperature about the roots.

AFTIR-CUITURI. The grass should not be allowed to grow around young trees after being planted, as it stunts their growth. The ground should be kept loose and clean around them until, at least, they are of bearing size.

\section{SELECT APPLE TREES}

Price 2 years old, each, $\$ 1.00$. Selected 2 to 3 years old, each, $\$ 1.50$.

\section{SUMIMIER VARIETIES}

RED ASTRACHAN. Large, deep crimson, flesh white, moderately juicy with an agreeable rich acid flavor; very productive.

YEIIOW TRANSPARINT. Medium size, roundish, slightly conical; skin pale yellow; flesh tender, juicy, sub-acid; good.

RבD JUNE. Very similar to the Red Astrachan; ripens about the same time.

\section{FALL VARIETIES}

BEIIFIOWRR. Large, yellow, fine flavor.

DUCHESS OF OIDENBURG. Red and yellow streaked, very desirable.

GRAVENSTIIN. Large, beautifully dashed with deep red orange; tender and crisp, with a highly aromatic flavor; tree very vigorous.

MAIDEN BIUSH. Medium; well shaped. Yellow with red on sunny side. Flesh white. Pleasant sub-acid flavor.

WEAITHY. Yellow, shaded deep red. Tree vigorous and fruit of fine quality.

\section{WINTER VARIETIES}

ARKANSAS BIACK, Excellent flavor, fine.

DErICrous. Red shaded, yellow, and as the name implies.

GRIMTS GOIDEx. A late yellow apple; a good keeper.

JONATHAN. Medium conical; brilliant, covered with red stripes; tender and juicy; excellent for table or market.
KING OF TOMPKINS COUNTY. Very large, globular; yellowish, shaded with red; flesh yellow, rather coarse, juicy; rich flavor.

NORTHERX SPY. Large, round greenish yellow, stripes of purplish red; Mesh white, juicy, brisk sub-acid; valuable for market and cooking.

SPITZINBERG. Large, oblong; yellowish ground with broken stripes of bright red; flesh yellow, juicy with a delicious, rich flavor.

STAYMAN WINESAP. Medium; yellow ground, streaked with red; flesh yellow with rich, high flavor; excellent for table and making cider.

WAGNER. A good keeping late variety; one of the best for this locality.

WINTER BANANA. Winter; yellow, blush cheek; sub-acid: medium size.

\section{CRAB APPLES}

\section{PRICE, EACH $\$ 1.00$ TO $\$ 1.50$.}

Very desirable for jellies and preserves. Some of the newer varieties are delightful table eruits; all are unequaled for cider or vinegar. The trees are very hardy and usually bear the second season after planting.

FLORENCE. Large red. One of the most beautiful of the Crabs, very popular.

HYSIOP. Deep crimson.

TRANSCENDENT. Very productive; bright red, one of the most popular.

RED SIBERIAN. Red cheek on a yellow ground.

TrLLOW STBRRAN. Beautiful golden-yellow. 

Tested Seeds are worth more
Ours are tested

PEARS

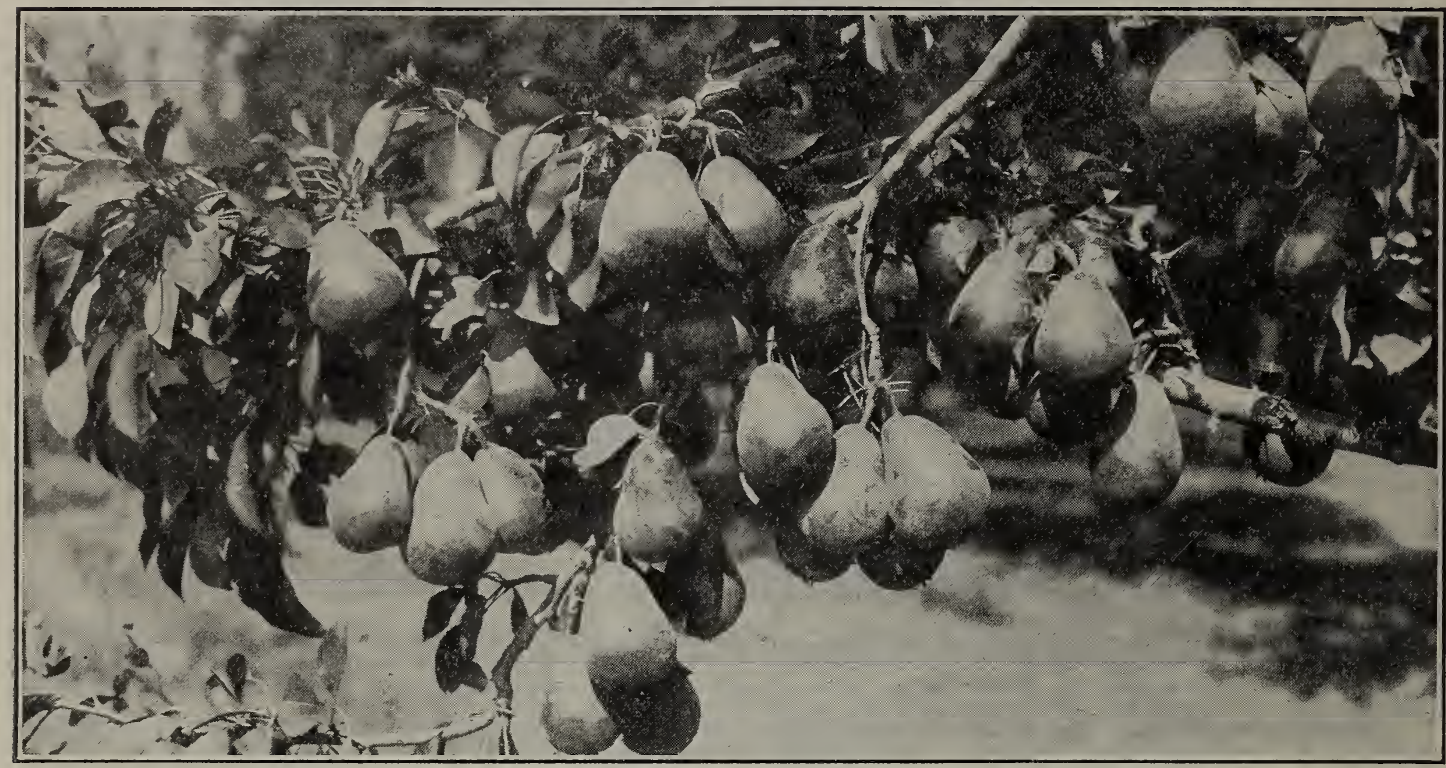

ZUER

Price, 2 years old, $\$ 1.00$ each. Selected, 2 to 3 years old, $\$ 1.50$.

\section{SUMMER VARIETIES}

BARTLETT. The best Summer Pear. Large, buttery, highly flavored and very prolific. It has long been the favorite both for eating out of hand and for canning.

CIAPPS FAVORITE. Very large. Yellow and dull red, with russet specks. Rich, August.

FALL AND WINTER VARIETIES

BEURRE DE ANJOU. Best Winter Pear. Large, fine flavor; tree vigorous and very prolific. Fruit will keep until Christmas.

FIEMIST⿱ BEAUTY. Fruit large, pale yellow. Flesh melting. tender and of high quality. September.

COMICE. Yellow large quality. fine.

WINTER INEIIIS. Medium size, of good quality; very late and a good lieeper.

WIITER BARMIETT. Large, good quality fine grained.

\section{CHERRIES SWEET}

Price, 2 years old, each, $\$ 1.00 .2$ to 3 years old, selected, each, $\$ 1.50$ to $\$ 2.00$.

BING. Very large, color dark brown-almost black; flesh firm, sweet and delicious. One of the most profitable varieties.

IAMIEERT. Fruit of largest size and of fine quality; color deep, rich red; flesh firm and of fine flavor; a fine market variety; ripens two weeks earlier than Royal Anne.

ROYAL ANN. Sweet: light red; June and July. BIACK REPUEIICAN. Very early; fine flavor, and good producer.

\section{CHERRIES SOUR}

EARIY RICHMOND. The finest sour pie cherry grown

ENGIISR IMORELIO. The old flavored English pie cherry; best for preserves.

MAY DUKE.' Large, rich, dark red; flesh tender, juicy and sub-acid; an excellent variety and one of the earliest of its class.

MONTMORENCY. Large red, a very satisfactory variety for this locality, best for canning.

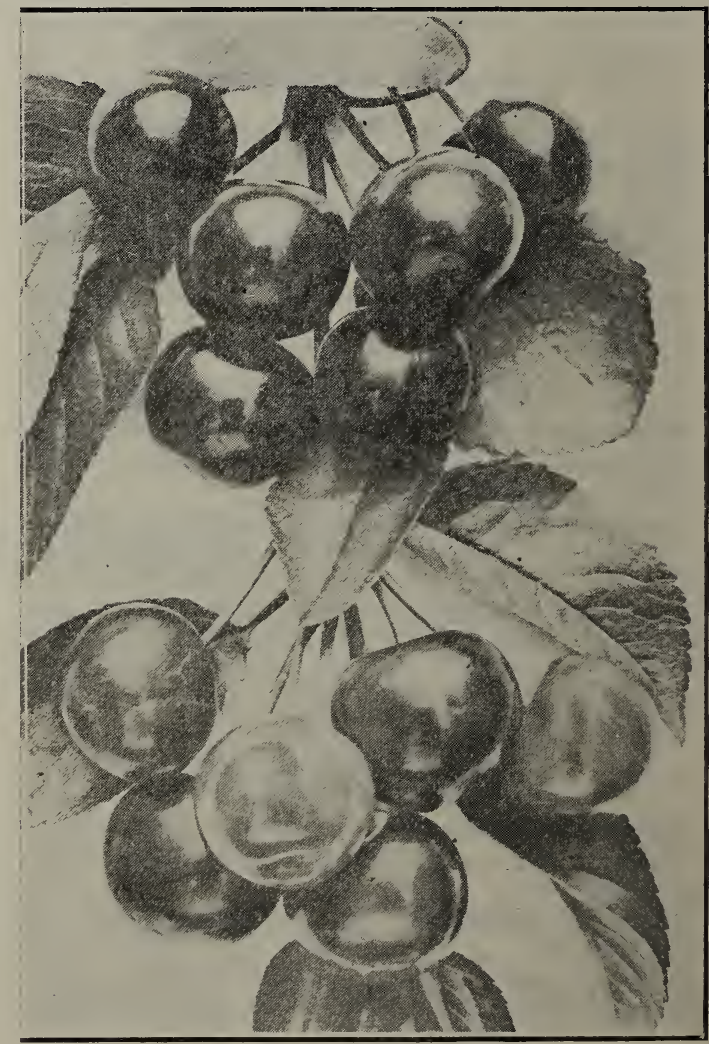




Hoover says "Eat lots of vegetables"
They'll save the meat

\section{STRAWBERRY PLANTS}

CULTIVATION. When the plants begin to spread and the roots to extend, care should be taken that the roots be not injured by the cultivator, and our plan is to shorten the cultivator teeth that run next the plants by about two inches. When thus shortened the teeth will go sufficiently deep to breali the crust near the plants without danger of cutting the roots of the plants. About two times a month we run the five-tooth cultivator through the center of the space between the rows, stirring the soil to a depth of four or five inches. This loosens up the soil where the horse has tramped it down when doing the shallow cultivation.

One very important practice you should adopt whether your last cultivation be early or late; be sure before stopping the work to make a furrow four or five inches deep down the center of the space between the rows of plants, so that, all surplus water from rains or melting snows may have immediate outlet. This will prevent its settling about the crowns.

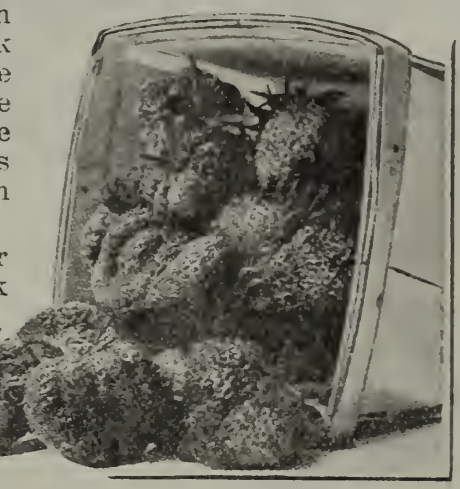

PRICE LIST OF PLANTS

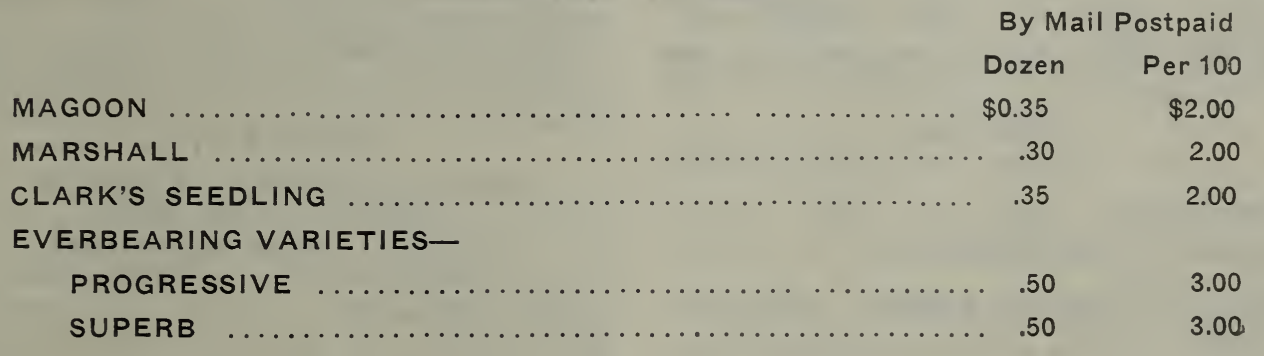

MAGOON. A large, dark red berry, very prolific and ripens early in the season, being the first on the market in this vicinity. A splendid berry for the table.

MARSFAII. A very handsome, large, bright red berry that ripens just a little later than the Magoon. A good canning and table berry and a good shipper.

CIARK'S SEEDINGG. Follows after the Marshall and is not quite so large. Bright red and of exceptionally fine flavor; an excellent berry for canning and a good shipper, it is rapidly becoming the most popular Strawberry.

\section{FALL-FRUITING STRAWBERRY}

While they will produce fruit at the same season as the ordinary strawberries and keep on bearing until frost, yet to get the best results the blossoms should be kept cut off until August 1 st so as to conserve the energies of the plants for the fall crop. Treated in that way ripe fruit will be borne in about three weeks after that date and continuously until frost. One grower by that method gathered nearly 400 quarts from 500 plants set out in the spring; a splendid demonstration of their productive power. The quality is superb, the size is good, but not up to the late June berries, because of the season at which they are borne. The plants must not be allowed to suffer for water in the frulting season and a mulch will be found to be of great advantage. High cultivation is essential for the best rerults in all crops and in growing these strawberries a little extra attention will pay well. There is no more trouble to grow them than the ordinary strawberries, but they have to be attended to in proper season.

PROGRESSIVE. A splendid grower, healthy and hardy, very productive. The plant is of medium size, the blossom strongly staminate and very resistant to heat. Both blossoms and fruit are well protected by the strong, healthy foliage. The fruit is rich and sweet; a deep red inside and out: of good medium size with a slight neck and quite firm. Plants set in August and September fruit the next spring and on the new runners from July until frost. Spring set plants fruit the same year they are set out.

SUPERB. One of the best and most profitable of the fall bearing sorts, also yielding good crops in June, on the same plants that produced fruit the previous fall. Plants are strong and stand the winter well after producing a heavy crop of fruit from about August 15 until November 15 , according to season. Fruit is very large, round, rich, dark colored, glossy, attractive and smooth. Each berry Is of good shape and ripens all over at once. 


\section{APRICOTS \\ PRICE, SELECTED 2-YEAR-OLD STOCK, EACH $\$ 1.50$}

IEWIS. Probably of Russian origin, a hardy, vigorous tree, regular and abundant producer. Fruit large, roundish but considerably compressed or flattened on its sides. Handsome orange color with flushed cheeks; flesh juicy, sprightly flavor, very firm, making it an ideal market variety

MOORPARK. Very large yellowish-green, brownish-red on sunny side; flesh bright orange; fine for canning or drying; free-stone.

ROYAI. Above medium size; sweet, rich and juicy.

\section{PLUIMS}

PRICE, SELECTED 1-YEAR-OLD \$1.00, 2 TO 3 YEARS OLD $\$ 1.50$ TO $\$ 2.00$

BURBANK. Red cheek on yellow ground, prolific.

BRADSFAW. Reddish purple, juicy and pleas. ant; adheres partially to the stone.

CoIUMBIA. Large size, nearly globular; brownish purple; rich, sugary, freestone.

DAMson. Small, oval; skin purple; flesh melting, rather tart.

GREEN GAGE. Small, rouna; flesh pale green, melting and juicy; freestone.

PEACF. Very large; skin brownish red; slightly coarse grained but juicy; freestone; very popular.

YEIIOW EGG. Very large; skin of a deep golden color, but rather acid; excellent for cooking; very showy.

\section{PRUNES}

Price. 1 year old, each $\$ 1.00$. Strong selected, each, $\$ 1.50$

HUNGARIAN. Very large, bright red; rich and juicy; fine for eating.

ITAIIAN. Dark purple, sweet; fine for canning or drying.

FETITE or FRENCH PRUNE. Medium size, reddish-purple; very sweet. ing.

SIIVER. A large sweet Prune; good for dry-

\section{PEACHES \\ PRICE, SELECTED 2-YEAR-OLD TREES, EACH $\$ 1.00$ TO $\$ 1.50$}

FARIY CRAWFORD. Very large yellow, with red cheek; flesh sweet and excellent; our most popular peach for table and canning; freestone.

ELBERTA. Very large, bright, yellow, red cheek; flesh yellow, juicy, sweet, regular bearer; ruit very showy and perfect; freestone.

IATE CRAWTORD. A superb, large yellow Peach: freestone

HAIES EARIY. A rather new variety but rapidly coming into favor. A good Peach for this locality.

\section{QUINCES}

PRICE, 2-YEAR-OLD STOCK, EACH

$\$ 1.50$ TO $\$ 2.00$

CHAMPION. A prolific and constant bearer; fruit of good quality and keeps well.

ORANGF. Fruit large, bright yellow and of good flavor.

\section{SMALL TRUCKS AND BERRIES GOOSEBERRIES \\ PRICE, TWO YEARS OLD, EACH 35c; DOZ. $\$ 3.50$ \\ EXTRA LARGE SELECTED}

PLANTS, EACH 50c; 10 FOR $\$ 5.00$

OREGON CHAMPION. Berries very large, pale green color; very sweet and fine for table use and pies; bush strong, not very thorny; very prolific bearer; most popular sort we have.
RED JACKET JOSSEIYN. Of large size, smooth, prolific and hardy; of best quality; a wonderful cropper, with bright, clean, healthy foliage.

INDUSTRY. Large oval; dark red, hairy; rich and agreeable; vigorous and productive.

PEARL. Very large yellowish green. One of the finest European berries. For eating ripe they are delicious. No garden should be without a few bushes.

\section{GRAPFS}

PRICE, EXTRA LARGE, STRONG ROOTS, EACH 50c; DOZEN, $\$ 5.00$

CAMPBEII'S EARIY. Black, large and very fine quality.

Grapes can be grown successfully in this 10cality if care is used in selecting a suitable spot. A slope with a southerly or south-westerly exposure is the best.

NIAGARA. Fruit large, pale yellow when ripe; quality much like the Concord.

DEIAWARE. A small compact, light red grape; flavor sweet and spicy, very delicious.

CONCORD. Large, purple, bright bunches, very long; an erect grower; late, productive and very valuable.

MOORE'S DIAMOND. Delicate, greenishwhite, with rich yellow tinge. Prolific, early and hardy. Of fine quality.

MOORE'S FARIY. Bunch medium; berry large, resembling Concord, but more pulp, and is arlier.

\section{CURRANTS}

PRICE, ONE-YEAR-OLD PLAN'TS, EACH 35c; DOZ. $\$ 3.50$

EXTRA LARGE SELECTED

PLANTS, EACH 50C; DOZ. $\$ 5.00$

FAY'S PROIIFIC. A new currant which has well sustained the claims of its disseminator; it is larger than the cherry, has less acid and is much more prolific.

BIACI NAPIES. Very large, black; valuable for jams and jellies.

CHIRRY. Very large; deep red; fine for preserving; valuable market variety.

PEREFCTION. Large, red, prolific and of finest quality.

WHITE GRAPE. Best white variety.

\section{BLACKBERRIES}

PRICE, EACH 20c; DOZ., $\$ 2.00$

IAWTON. A splendid bush berry.

EVERGRㅗㅛN. Very prolific, of good size and appearance; they stand up well for shipping. Splendid for canning.

FIMAIAYA, or EVER-BEARING. A remarkable berry, producing immense crops of exceedingly large, sweet, juicy berries, with a delicious aromatic flavor. The plant is a rampant grower single canes often making a growth of fifty feet in one season. The berries are produced in immense clusters, beginning to ripen in July and continuing until winter. The original plants were brought from the Himalaya Mountains, where they have been grown for many centuries. and the severe climate has made them - unusually hardy, enabling them to withstand extremes of cold, heat and drought. Each, $25 \mathrm{c} ; 13$ for $\$ 2.00$.

NEW MAIMMOTH. A very choice new variety,

SNYDER. Very productive, medium sweet without a hard, sour core. It is extremely hardy and ripens early.

DEWBERRY (Iucretia). A low-growing trailing blackberry Very large, sweet berries of good firm quality; perfectly hardy. 


\section{HYBRIDS}

\section{BURBANK'S PHENOMENAL}

A NEW BERRY. Mr. Burbank's latest triumph. It is a cross between the "Improved California Dewberry" and the "Cuthbert Raspberry." Takes its color and flavor from the latter and size and shape from the former. Price, 2 year old, each, 35c; doz. $\$ 3.50$.

\section{LOGANBERRY}

(Raspberry - Blackberry). This comparatively new berry is becoming more popular each year. An exceedingly strong grower and an enormous bearer. Price, 2 year old vines, each, 50c; doz. $\$ 5.00$. Tips, each $25 \mathrm{c} ;$ doz. $\$ 2.50$.

\section{RASPBERRIES}

\section{PRICE, EACH 20c; DOZ., $\$ 2.00$}

GREGG (Black). Best late black-cap, market favorite. Canes strong, productive; berries large, covered with bloom; firm, meaty and fine flavor.

MARIBORO. Fruit of largest size, bright scarlet, excellent flavor. Good shipper, heavy canes, early and hardy.

ST. REGIS. A genuine, practical, profitable, continuous-to-fall bearing red raspberry. Fruit commences to ripen with the earliest and continues on young canes until October. Berries bright crimson, large size, rich, sugary, with full raspberry flavor. Flesh firm and meaty, a good shipper. Wonderfully prolific. Canes stocky, of strong growth, with abundance of dark green feathery foliage.

CUTHBERT, or QUEEN OF THE MARKET. A remarkably strong, hardy red variety. Berries large, conical, rich crimson; flavor sweet, rich and delicious.

\section{WALNUT (English)}

WAINUT. (English). A lofty tree with a spreading head, producing delicious, thin-shelled nuts. Does well in this locality. Each, $\$ 1.5 \mathrm{~J}$ to

FRANQUETTE. Nut is quite large, elongated oval shape, very handsome with heavy, wellsealed shell. Kernel full fleshed, sweet and rich. Very desirable as a market variety. $4 \mathrm{ft}$. to $6 \mathrm{ft}$., each, $\$ 1.50$ to $\$ 2.00$. (Grafted) 6 to $8 \mathrm{ft}$., each, $\$ 3.00$. 3 to $4 \mathrm{ft}$., each, $\$ 1.00$ to $\$ 1.50$.

\section{FILBERTS}

BARCELONA. A magnificent variety of Spanish origin; nut large, round, first quality. Very productive; trained as a low standard tree or a bush.

DU CHIILY. The largest filbert fruited on the Pacific Coast. Elongated oval, very broad; often more than an inch long by three-quarters of an inch wide. Nuts uniformly large, well formed, full fleshed and sweet.

\section{CHESTNUTS}

AMrRICAN SWRET. The fruit is very sweet and fine flavor, rather small, but prolific and profitable.

ITALIAN of SPANISH. Large, good flavored nut: tree strong grower and productive; valuable for ornament and fruit. Strong trees, $35 \mathrm{c}$ a: $1 \mathrm{~d}$ $50 \mathrm{c}$; large specimens, 4 to $6 \mathrm{ft}$, each, $\$ 1.50$.

\section{I M E}

Gardeners are generally familiar with the litmus paper test to ascertain if soil is in need of lime.

The same is not true of the muriatic acid test $w$ hich is as follows. Place a drop of muriatic acid diluted four or five times, on the soil. If any perceptible bubbling or effervescense shows, it indicates the presence of sufficient lime. The best proof of the need of lime is the type of plant growth that the soil bears. The vigorous growth of lime loving plants, such as alfalfa or clover growth that the soil bears. The vigorous growth of lime loving plants, such as alfalfor or the presence of sufficient lime; weak growth of plants of this kind and the predominance of such plants as red-top, horse sorrel or white daisy show the soil is in an acid condition needing lime. Any tuber such as the potato that develops scab shows soil contains plenty of lime an additional supply will increase the growth of the fungus which is a serious trouble in this section. It is best not to plant potato seed on land which has grown scabby tubers. PIANT CLEAN SEED-if only scabby seed can be obained soak the uncut tubers in a solution of formalin, 1 pint to 30 gallons of water, for two hours. Drain, cut and plant in clean soil free from scab. Beet fields will often develop the same trouble consequently should not be planted after potatoes or on soil that has developed potato scab. Under present conditions commercial fertilizers must form the basis of fertilizer applications because the average farmer or gardener does not observe what the soil needs; shown through the medium of plant growth. Potash is now obtainable in various forms consequently manufacturers are able to supply complete mixtures that will give definite and satisconsequently manufacturers are able to supply complete mix
factory results-SUPERIOR-brands will prove profitable.

Provided a grower wishes to obtain the different ingredients and make a special mixture suited to peculiar soil needs we will gladly furnish the separate products to mix the desired formula. 


\section{LIME}

\section{GROUND LIME ROCK}

(Ground to 100 mesh fine). (90\% Calcium Carbonate). Especially prepared for use on the lawn and garden. Based on chemical analysis, it may safely be said that practically all the soil in the Puget Sound district is in need of lime. Different sections require different amounts, but from wide experiments it has been shown that practically all the land needs at least 2,000 pounds per acre. This applies to gardens and farms; for lawns a fair application is 100 pounds to 2,000 square feet. After wide experiments it has been found that the Lime Rock is much superior to other forms of lime, as it is not caustic and will not destroy the humus in the soil. It can be applied to a growing crop without any chance of injury.

\begin{tabular}{|c|c|}
\hline $\begin{array}{l}\text { 5-1b. pkg. } \\
100-1 b . \text { sack }\end{array}$ & 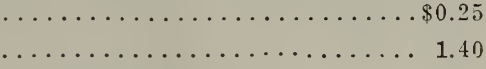 \\
\hline $2,000-1 b$. sack & 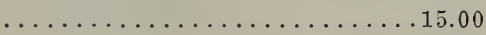 \\
\hline
\end{tabular}

This price is for delivery any place in the city and to docks and depots.

\section{HYDRATED LIME}

Many prefer Hydrated Lime to Lime Rock, claiming that it acts sooner in liberating plant food for consumption. Hydrated Lime is ground as fine as flour, rendering it available as soon as applied.

Hydrated Lime is especially valuable for lawns, as it not only sweetens the soil, unlocks valuable plant food, but kills out weeds and moss without injuring the grass in the least, giving your lawn that rich green color so much desired.

It will give deeper color to roses and other flowers and more strength to resist the hot rays of the sun.

Applied to the garden it wrill increase the yield $25 \%$ and will improve the quality of the vegetables.

Hydrated Lime can be used on the Lawn the same as Lime Rock, but must be used with more caution on the garden, as too strong an application might destroy the humus to some extent.

For lawns, use $100 \mathrm{lbs}$. to $2,000 \mathrm{sq}$. $\mathrm{ft}$. 100 lbs., $\$ 2.00$.

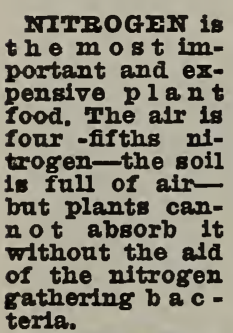
terla.

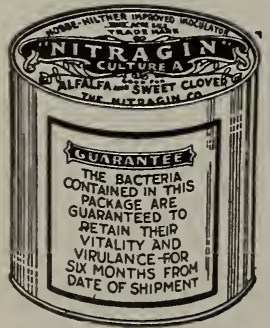

One-Acre Size

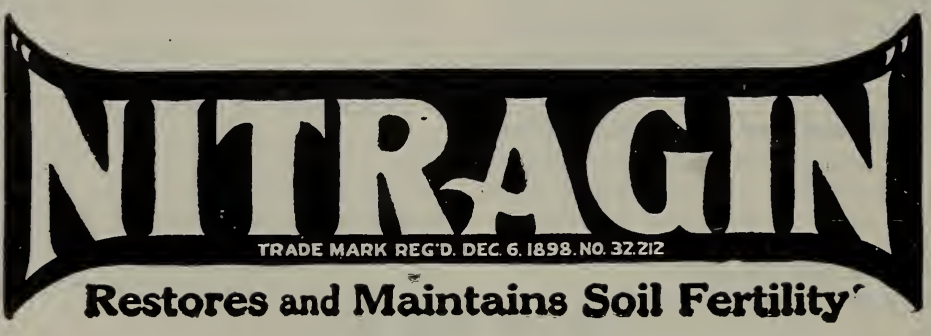

To Insure a stand-increase the yield-build up your mollalways 1 n o c ulate CIOVIRs, AIFATFA. VFTCHMS PFAS, BDAxS, SOYA BMANS, COW PEAS with

NITRAGIT

There has been no discovery in recent years so valuable to agriculture as the discovery of "NITRAGIN."

NITRAGIN is the trade name applied to NITROGEN GATHFRING BACTERIA, and will enable almost any soil to produce leguminous crops in abundance.

It is of two-fold value, as it insures a catch of any legume on worn-out or poor soil; at the same time that legume is a sturdy deep-rooted soil renovator.

By plowing under the green crop you will add humus and fertilizer that makes the land available for other crops.

Price-Garden size, 35c; $1 / 2$-acre size, 50c; 1 -acre size, $\$ 1.00$.

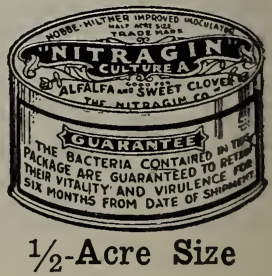


STUDY THE NEEDS OF YOUR SOIL AND FEED IT SCIENTIFICALIY; IT IS JUST AS IMPORTANT AND TIELDS THE SAME RESULTS AS FEEDING YOUR STOCK.

\section{SUPERIOR LAWN AND ROSE FERTILIZER}

The constant mowing of the lawn and removing of the cuttings removes large quantities of the nourishment of the soil. This has to be replaced. If you desire the lawn to have the rich green coloring and assure yourself of a lawn the year around our Superior Lawn Fertilizer should be used at least once a year. It should be scattered broadcast during the early spring, to obtain the best results, although it can be used during the fall or winter. About 50 lbs. to 1,000 square feet. It is odorless and there is no possibility of putting weed seed into your lawn.

VERY QUICK ACTING. TESTED BY THE STATE CHEMIST. PRICE:

5-lb. pkg. $\$ 0.40$

10-1b. sack

25-lb. sack

50-1b. sack

2.50

100-1b. sack

\section{SUPERIOR VEGETABLE FERTILIZER}

If you are to obtain satisfactory yields from your garden you must put back the elements which the plants are constantly taking from the soil. Superior Vegetable Fertilizer is especially designed to replace those elements most needed in the garden. It is absolutely free from reed seeds.

Use about $100 \mathrm{lbs}$. to $2,000 \mathrm{sq}$. ft.

\section{PRICE:}

5-lb. pkg. $\$ 0.40$

10-1b. sack

25-lb. sack

50-1b. sack

100-Ib. sack

\section{BONE MEAL}

\section{BONE MEAL. (Nitrogen, 3\%, Phosphoric Acid 15\%)}

Decomposes slowly in the soil and is therefore an excellent permanent fertilizer. Fine for top dressing on lawns on account of its lasting qualities. Five pounds placed whole before planting rose bushes will produce great results. Cur bone meal is made from fresh bones, and has lost any of its value. The quantity to use depends entirely upon the purpose for which it is used. Iight applications are beneficial, but for permanent work, such as forming soil for lawns, rose beds, etc., it should be used in very large quantities, the more the better. 5-1b. pkg., $40 \mathrm{c} ; 25$ lbs.., \$1.50; 1001lb. sack, \$4.J0. 


\begin{tabular}{|c|c|c|}
\hline $\begin{array}{l}\text { We want your trade } \\
\text { W' } \text { w }^{\prime} \text { surely please you }\end{array}$ & WOODRUFF & $\begin{array}{l}\text { It always pays to use } \\
\text { fertilizer on your garden }\end{array}$ \\
\hline
\end{tabular}

\section{WHALE FERTILIZER}

\section{ALASKA WHALE FERTILIZER. (Nitrogen 8.96\% Phosphoric Acid 28.23\%)}

A balanced fertilizer especially adapted for vegetable and flower gardens. It is made from the entire carcass of the Alaska whale after the oil has been extracted and is far superior to any other fish fertilizer. It produces wonderful results when used in the orchard or around berry bushes. From 6 to 10 pounds applied to a bearing fruit tree is sufficient and the results produced are marvelous.

10-lb. sack, 75c; 25-1b. sack, $\$ 2.25 ; 100-1 b$. sack, $\$ 5.50$.

\section{BLOOD AND BONE \\ BLOOD AND BONE. (Nitrogen 4\%, Phosphoric Acid 12\%)}

Is quick acting and on account of its richness in nitrogen and phosphate is a very desirable fertilizer. Best used around roses just before exhibiting time. An animal fertilizer, rich in nitrogen and phosphoric acid, and having additional value on account of a certain warmen and vitality which it imparts to the soil. It is a quick acting fertilizer, and for that reason it is for some purposes more valuable than bone meal, although the effect is not so lasting. It should not be applied a great length of time before the seed is planted, and may be used as a top-dressing. It is usually applied at the rate of 500 to $1,000 \mathrm{lbs}$. per acre. $100 \mathrm{lbs}$., $\$ 4.00$.

\section{NITRATE OF SILVER NITRATE OF SODA. (Nitrogen 19\%)}

Contains $13 \%$ or more of nitrogen in quickly available form, and is generally used as a top-dressing. It is seldom advisable to apply it on the soil before the seed is sown, for the reason that all the benefits will be had from it within two or three weeks, and if the plants are not ready to make use of all the plant food, some of it will be lost.

It is best applied in several light applications of about $150 \mathrm{lbs}$. each per acre, at intervals of two or three weeks, during the early growing season. If applied too late, the plants will continue to grow foliage, and maturity will be retarded. It is used for forcing such crops as lettuce, celery, radishes, etc., requiring a quick growth, and produces wonderful results. $1 \mathrm{lb} ., 10 \mathrm{c} ; 100 \mathrm{lbs} ., \$ 6.00$.

\section{ROCK PHOSPHATE \\ GROUND ROCK PHOSPHATE}

Raw phosphate rock finely ground. It is slower acting than superphosphate, and is recommended by many manufacturers as the most economical form of phosphoric acid. $100 \mathrm{lbs}$. $\$ 2.00$.

On account of the war we are unable to supply any potash as the supply all comes from Europe, and it is impossible to import any at this time.

\section{SUPERPHOSPHATE}

\section{SUPERPHOSPHATE. (Guaranteed Analysis, Phosphoric Acid 17\%)}

This is what is known as Acid Phosphate, being phosphate rock treated with acid to make the phosphoric acid available. While the phosphoric acid in this is not so valuable as that in bone meal, it is more quickly available, and in some cases more useful.

Superphosphate is recommended as a top-dressing for grass lands and for grain. It is generally used at the rate of 500 to $1,000 \mathrm{lbs}$., per acre. $100 \mathrm{lbs} ., \$ 2.50$. 


\section{SPRAYING CALENDAR AND FORMULAE}

There is no spraying that will cure everything. Use the one that fits your case. Spraying, to bo effective. must be well done.

\begin{tabular}{|c|c|c|c|}
\hline Whon to Epray & What to Vse & What to Spray For & Notes \\
\hline $\begin{array}{l}\text { FALL } \\
\text { Just after the } \\
\text { leaves fall. } \\
\text { Especially for } \\
\text { Western } \\
\text { Washingten. }\end{array}$ & Sulphur-lime & $\begin{array}{l}\text { Apple cankers. } \\
\text { Scale insects. } \\
\text { Eggs of green aphis and red } \\
\quad \text { spider. } \\
\text { Pear leaf blister mite. } \\
\text { Woolly aphis. } \\
\text { Eggs of tent caterpillar. } \\
\text { Moss and lichens. } \\
\text { Rabbits and field mice. } \\
\end{array}$ & $\begin{array}{l}\text { This spraying may be preceded by a spray- } \\
\text { ing of bordeaux as soon as crop is } \\
\text { picked; for canker only. } \\
\text { Write for bulletin on sulphur-lime spray- } \\
\text { ing. }\end{array}$ \\
\hline $\begin{array}{l}\text { WINTER } \\
\text { While buds are } \\
\text { awelling. } \\
\text { Usual praying } \\
\text { where there is } \\
\text { no canker. }\end{array}$ & Sulphur-lime & $\begin{array}{l}\text { Bud moth; twig borer; } \\
\text { peach-leaf curl. } \\
\text { Scale insects. } \\
\text { Eggs of green aphis and red } \\
\text { spider. } \\
\text { Woolly aphis. } \\
\text { Rabbits and field mice. } \\
\text { Mildew. }\end{array}$ & $\begin{array}{l}\text { Too early spraying will miss these. } \\
\text { Write for bulletin on sulphur-lime spray- } \\
\text { ing. }\end{array}$ \\
\hline $\begin{array}{l}\text { SPRING } \\
\text { (1) When flower } \\
\text { buds are ready } \\
\text { to open. } \\
\text { (8) While last } \\
\text { blossome are } \\
\text { falling. }\end{array}$ & $\begin{array}{l}\text { Sulphur-lime } \\
\text { Lead arsenate } \\
1 \text { lb. to } 50 \\
\text { gallons. }\end{array}$ & $\begin{array}{l}\text { Apple scab. } \\
\text { New York apple canker. } \\
\text { Prune brown rot or fruit } \\
\text { mold. } \\
\text { Codling moth. } \\
\text { Bud moth; twig borer. } \\
\text { Caterpillars. }\end{array}$ & $\begin{array}{l}\text { Spray when central flower of cluster is } \\
\text { about to open. } \\
\text { Use a bordeaux nozzle with a crook and } \\
\text { spray with force from raised platform } \\
\text { directly into every flower. Repeat im- } \\
\text { mediately. If so applied, these sprayings } \\
\text { are sufficient. Keep a few trees banded. } \\
\text { If many worms are trapped, spray. } \\
\text { Write for codling moth bulletin. } \\
\text { Not advisable to mix with arsenate of lead. } \\
\text { Omit if there is little scab. }\end{array}$ \\
\hline $\begin{array}{l}\text { SUMMFLR } \\
\text { When the pest } \\
\text { appears. }\end{array}$ & $\begin{array}{l}\text { Tobacco (or } \\
\text { kerosene } \\
\text { ernulsion). }\end{array}$ & $\begin{array}{l}\text { Aphis (cherry aphis, etc.) } \\
\text { WVolly aphis on branches. } \\
\text { Red spider. } \\
\text { Oyster shell bark louse. } \\
\text { Leaf hopper. } \\
\text { Pear and cherry slug. } \\
\text { Caterpillars. } \\
\text { Colorado potato beetle. } \\
\text { Fruit spot (Baldwin spot; } \\
\text { punk rot). } \\
\text { Mildew. } \\
\text { Red spider; young of oyster } \\
\text { shell louse. } \\
\text { Trunk borer; flat head borer. } \\
\text { Flea beetles. } \\
\text { Cutworms. } \\
\text { Grasshoppers. } \\
\text { Potato blight. }\end{array}$ & $\begin{array}{l}\text { About June } 15 \text { for newly hatched young. } \\
\text { Spray early before they acquire wings. } \\
\text { Use } 1 \text { pound to } 75 \text { gallons. Or dust witb } \\
\text { lime, ashes or road dust. } \\
\text { Use } 1 \text { pound to } 40 \text { gallons. } \\
\text { Early in July. (Treatment in the experi- } \\
\text { mental stage.) } \\
\text { Keep trunk coated all summer; best to add } \\
\text { excess slime. } \\
\text { As a repellant. } \\
\text { July } 1 \text { to } 15 \text {; repeat in two weeks. If much } \\
\text { blight near by, give third application } \\
\text { two or three weeks later. }\end{array}$ \\
\hline
\end{tabular}

\section{SPRAYS}

\section{INSECTICIDES AND REMEDIES FOR FUNGUS}

Most of the following articles being poisonous, cannot be shipped by mail:

\section{ARSENATE OF LEAD

$$
1 / 2 \text { lb., 40c; } 1 \text { lb., } 75 \mathrm{c}
$$

Dry Arsenate of Iead is rapidly gaining in favor over the paste. It has none of the disadvantages of the paste form and many advantages that the older form does not possess..

Dry Powdered Arsenate of Iead is an exceedingly finely divided, fluffy powder which is much easier to get into suspension in the spray tank than is any other form of Arsenate of Lead.

Use 1 to $1 \frac{1}{2} \mathrm{lbs}$. to 50 gals. of water.

\section{DRY POWDERED FUNGI-BORDO}

$$
\text { I/2 Ib., 40c; } 1 \text { Ib., } 75 \mathrm{c}
$$

Fungi-Bordo is a dry powder Bordeaux put up in sift-proof impervious packages. It is easily held in suspenston and can be used with excellent results in combination with Paris Green, Arsenate of Lead or other insecticides. You pay no freight on water when you buy Dry Powdered Bordo.

Usually $8 \mathrm{lbs}$. to $50 \mathrm{gals}$. of water wll prove very effective. 
Do not trust to luck in ordering seeds-Ours are tested

\section{SPRAYS-Continued}

\section{BLUE STONE}

\section{PER LB., 30c}

Blue Vitriol or Copper Sulphate. Used in making Bordeaux Mixture.

\section{DRY LIME SULPHUR}

1. LB. $30 \mathrm{c}, 5$ LBS. $\$ 1.00 .10$ LBS. $\$ 1.75$, 100 LBS. $\$ 10.50$

For many years growers have been using liquid Lime Sulphur Solution. They are thoroughly familiar with its use and the results it will accomplish, and there is no question whatever regarding its efficiency as a spraying material. It is a conceded fact, however, that the use of Lime Sulphur Solution carries with it many disadvantages. For instance; it weighs approximately six hundred pounds to the barrel; it is very disagreeable to handle; there is considerable waste when using it, and it cannot be carried over safely on account of leakage, danger of freezing, etc.

Dry Iime-Sulphur enters into solution in water almost instantly and spraying operations can be started immediately.

Packages should be stored in a dry place and kept tightly sealed at all times.

$80 \mathrm{lbs}$. of Dry Iime-Sulphur will produce 400 gals. of spray for dormant work.

\section{LIME AND SULPHUR SOLUTION} PRICE-QT. 30c, 1 GAL. 75c, 5 GALS. $\$ 2.50$, 1 BBL. $\$ 13.00$

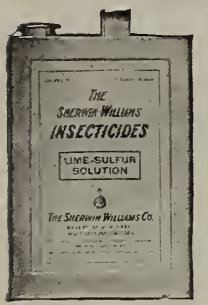

For those who still prefer the old style sulphur spray we can still furnish Lime and Sulphur Solution. This has been used by the orchardists of the Northwest for many years, and has long been the standard sulphur spray. We recommend Soluble Sulphur Compound as being just as effective, more convenient and less expensive, but some who have used Lime and Sulphur Solution with entire satisfaction will no doubt be averse to changing.

It is a clear, cherry-red solution, free from sediment, and tests 33 degrees Baume, which is as concentrated as it is possible to make a lime and sulphur solution which will remain in solution.

For winter or early spring spraying, before buds are open, it is used at the rate of one gallon of solution to eleven gallons of water. For summer spraying it is diluted with about twentyeight parts water.

\section{HELLEBORE}

PRICE-1 $/ 4$ LB. 25c, 1 LB. 90c

Pure Powdered White Hellebore is one of the best insecticides for general use on plants and vegetable foliage. Destroys insects that eat the leaves and flowers, such as Slugs, Caterpillars, Currant Worms, Cutworms, and if mixed with bran, Rose Bugs, and, in fact, most all the eating insects that pester the gardener and grower of plants. When used with water, $1 \mathrm{oz}$. to 2 gals. is the usual proportion. If used dry apply by dusting.

\section{PARIS GREEN}

\section{$1 / 4$ LB. 40 c, $1 / 2$ LB. $75 c, 1$ LB. $\$ 1.25$}

For all leaf-eating insects. The standard arsenical poison killing all leaf-eating insects, worms, slugs, etc. Cheaper than Lead Arsenate, but does not cling to the foliage so long. If used too strong will burn the foliage.

\section{TUBER-TONIC}

\author{
PRICE-1/2 LB. $40 \mathrm{c} ; 1$ LB., $75 \mathrm{c}$
}

This material is a very finely divided powder which is unaffected by heat or cold, and which reaches the consumer in perfect condition for use under any and all conditions, and which eliminates excessive freight charges, such as paste materials necessarily carry with them.

It stays in suspension well and sticks to the leaf almost indefinitely. Combining both insecticidal and fungicidal qualities, it simplifies spraying operations for the farmer and grower.

In the past, Paris Green has been recognized as the standard and most efficient potato spray for killing potato bugs, flea beetles, etc. Bordeaux Mixture has long been in use, as a reliable fungicide for controlling blight, scab and other potato diseases.

Both materials, however, have decided disadvantages. For instance, Paris Green does not stick to the foliage any great length of time, and is readily washed off by heavy dew or rains. Paste Bordeaux Mixture, either home-made or commercial, when sprayed separately has its disadvantages, and when combined with Paris Green it requires considerable time and labor to get them into thorough combination.

All of these disadvantages are overcome by the use of DRY TUBER TONIC. For general use $1 \frac{1 / 2}{2}$ lbs. to $3 \mathrm{lbs}$. to 50 gals. of water will prove effective.

\section{KEROSENE EIMULSION}

\section{PRICE-PINTS 45c, QUARTS 75c}

A safe and sure remedy for all Lice and Flies that infest plants and trees at times. It will destroy the Squash Bug, Oyster Shell Scale and all insects that take their nourishment through a proboscis. It is put up in a concentrated form, and dilutes with water from 10 to 30 times its bulk, according to the amount of insects on the plant. It is also used on the San Jose Scale a great deal when it is in the early stages. Apply with a vaporizer or with a pump the same as our other remedies. For plum curculio, spray just before the blossom buds open, and the second time two weeks after the petals fall. Adding a little Paris Green at this time will kill the leaf lice, aphides, bugs and other insects injurious to fruit and foliage. Spray the third time, about June 10th, with the plain Emulsion. Woolly Aphis of the Apple.-Same treatment as for the Plum Curculio.

\section{WHALE OIL SOAP PRICE-PER LB. 20c}

For Aphis, Plant Lice, etc. Is also useful for keeping the bark free from scale.

\section{NICO-FUIME LIQUID}

$1 / 4$ LB. $65 c, 1$ LB. $\$ 2.00,4$ LBS. $\$ 7.50$, 10 LBS. $\$ 14.50$

\section{NICO-FUIME PAPER}

24 SHEETS $\$ 1.25,144$ SHEETS $\$ 5.00$, 288 SHEETS $\$ 9.50$ 
Order early-All stock will bo short this year

\section{SPRAYS - Continued}

\section{"BLACK LEAF 40"}

Nicotine Sulphate- $40 \%$ Nicotine

This is the insecticide that is so highly recommended by Experiment Stations. It destroys Aphis (plant lice), Thrips, Leaf-hopper's on all tree, bush and vine fruits, vegetables, field crops, flowers and shrubs; also Apple Red Bug, Pear Psylla and similar soft-bodied sucking insects-all without injury to foliage.

May be combined with other sprays. Highly concentrated. Soluble in water-easy to mix-does not clog nozzles.

You can not go wrong by ordering "Black Leaf 40" for sucking insects.

\section{PRICES:}

1-oz. $\$ 0,25$-makes 6 gallons spray 1 -lb. 1.00 -makes 40 to $120 \mathrm{~g}$. spray 2-1b. 3.25 - makes 160 to $500 \mathrm{~g}$ spray $10-1$ b. 13.2 -makes $S 00$ to $2500 \mathrm{~g}$. spray

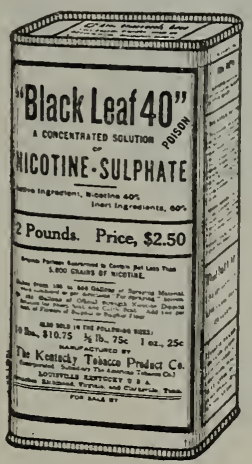

\section{CAR C O}

(Can be shipped parcel post)

Price- $\frac{1}{2}$ pts. $20 \mathrm{c}$, pts. $30 \mathrm{c}$, qts. $50 \mathrm{c}$, gals. $\$ 1.75$

\section{CARCO ROOT MAGGOT SPRAY}

The only remedy yet discovered that has proven effective against the Root Maggot. This spray has been used very extensively by truck gardeners during the past season on cauliflower, cabbage, onions and turnips, and they all report that it has real merit and does better work than any spray they have ever used to abate this nuisance. One user reports that on plants that were sprayed the loss was $15 \%$, while on those not sprayed the loss was about $22 \%$. It is diluted 100 parts, so there is very little chance of injury to the plants.
GRAPE DUST

PRICE-PER LB. 50c

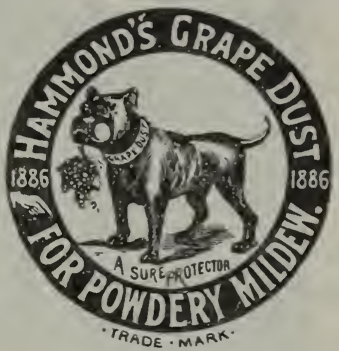

A powdered fungicide very efficient in destroying mildews and preventing blight.

SLUG-SHOT

PRICE-PER LB. 25c, 5 LBS. $75 \mathrm{c}$

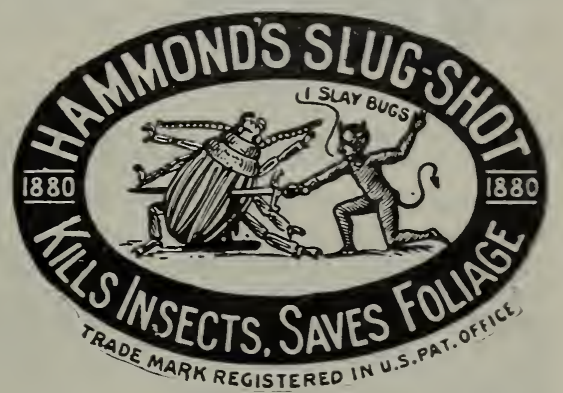

A non-poisonous powder and very popular insecticide. It requires no further mixing or preparation, easily applied and not injurious or angerous to anlmals, the person applying it, or fruits or vegetables treated. Destroys potato bugs, beetles, green and black fly, slugs, caterpillars, worms, etc. Very effective for cabbage lice and worms.

\section{TREE TANGLEFOOT}

\section{PRICE-PER LB. 40c}

For caterpillars, moths and worms. Protects against all climbing insects. One pound makes a band 9 feet long.

\section{GRAFTING WAX}

PRICE-1/4 LB. $20 c-1 / 2$ LB., $35 c$;

$$
\text { I LB., } 60 \text { c. }
$$

It is important that the wax should not soften and run after having been applied to the graft. Ours is made with this particular feature in view. It will not soften in the sun so as to run. It is, however, easily worked with the hand when being applied. If used in very cool weather, it may be more quickly softened by holding it over the stove for few moments. Besides its use for graft. ing, it is excellent if applied to young trees and shrubs if barked, and will re main on and prevent rot until the wound is covered with new bark. 


Our experience is at your servioe
Write us

\section{SPRAY PUMPS AND FITTINGS}

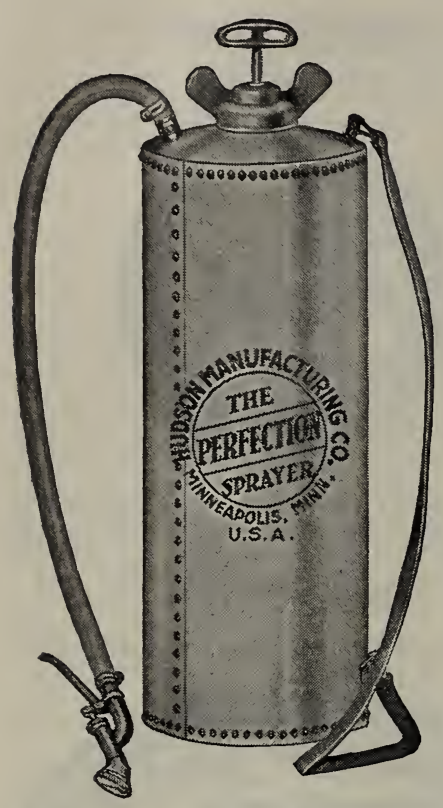

\section{PERFECTION SPRAYER}

The sprayer with a tank made like a steam boiler.

We carry these in both galvanized and solid brass.

The tanks are very strongly riveted and soldered from the inside. The air pump is placed inside, out of the way, and where it is not liable to damage.

The upper end is fitted with a casting, threaded to screw onto a cast brass ring brazed to the top head of the tank. Only one gasket is used. The joint is always tight and the pump is easily removed for filling the tank or for inspection. Capacity, 4 gallons.

Galvinized Tank....\$6.25

All Brass Tan $<. . . .10 .50$

\section{FAVORITE SPRAYER}

In this sprayer we have a moderate priced machine that will meet every requirement and give the best satisfaction.

It has many of the best features of the Perfection, but the pump is outside the tank. It is strong, well made and carefully finished. The tank is strong enough so that it is not necessary to equip it with a pop valve.

Capacity, $31 / 2$ gals. Price................... $\$ 6.00$.

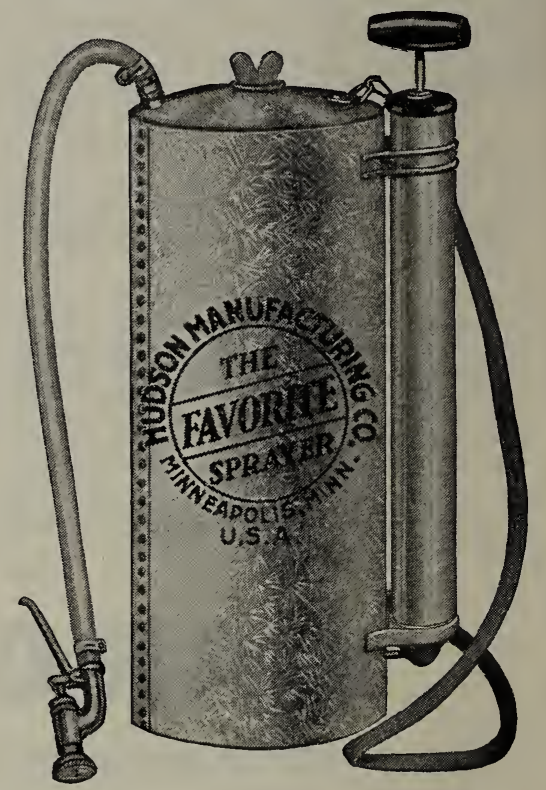

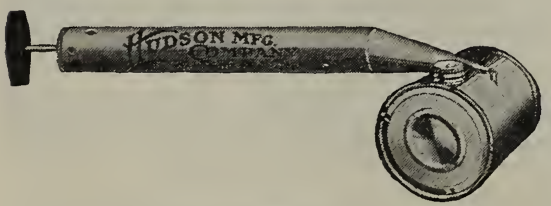

\section{NEW MISTY}

A good, strong, reliable sprayer, carefully made from good material. Every one is tested and will give satisfaction. Made with a lock seam without solder. Capacity, 1 full qt. Price..........50c

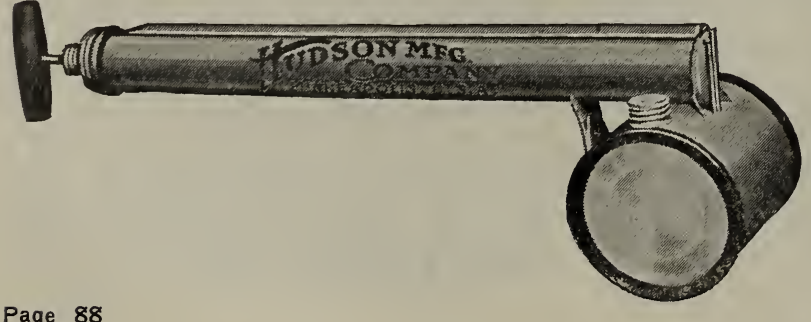

\section{DAISY}

A double-acting valveless sprayer. It will do twice the work of an ordinary sprayer, as it sprays on both strokes of the pump. Made with a galvanized tank and tin pump. They are carefully tested. Capacity, 1 full quart. Prlce.......75c
A small, well-made sprayer for household use. Will handle all kinds of liquids perfectly. The pointed nose of the pump passing through the tank makes it a very strong sprayer.
Capacity of tank about $3 / 4$ pt. Price............. 35 c 


\section{SPRAY PUMPS - Continued}

\section{MAGIC BUCKET PUIIP}

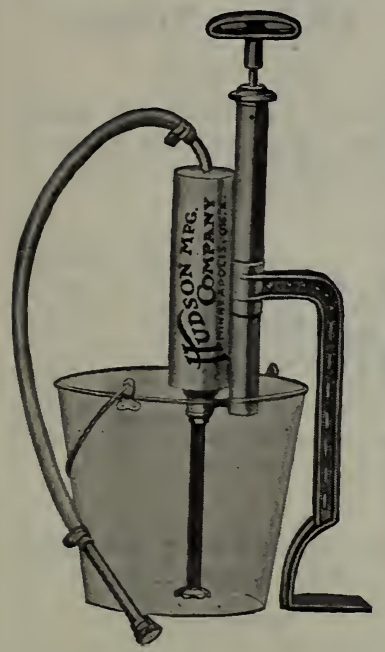

The only bucket $\mathrm{pump}$ in which both intake and outlet valves are mounted in one cage and easily removable. This pum p a s a large capacity, and all work being done on down stroke it is very easy to o perat e. All a rts except handle and foot rest are of brass.

Price, $\$ 6.50$

\section{AUTO-SPRAY, 40-B}

An effective. pump for general use. Galvanized tank, brass valves and plunger. Capacity, 8 gals.

Price $\$ 15.00$
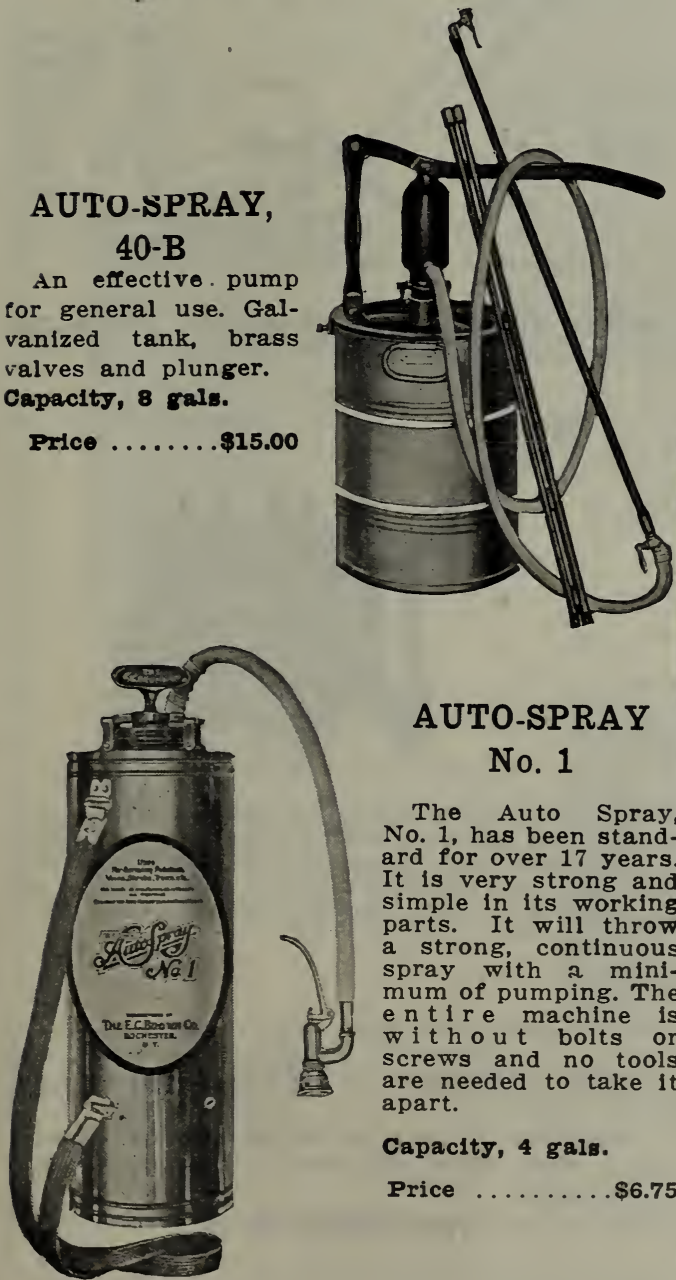

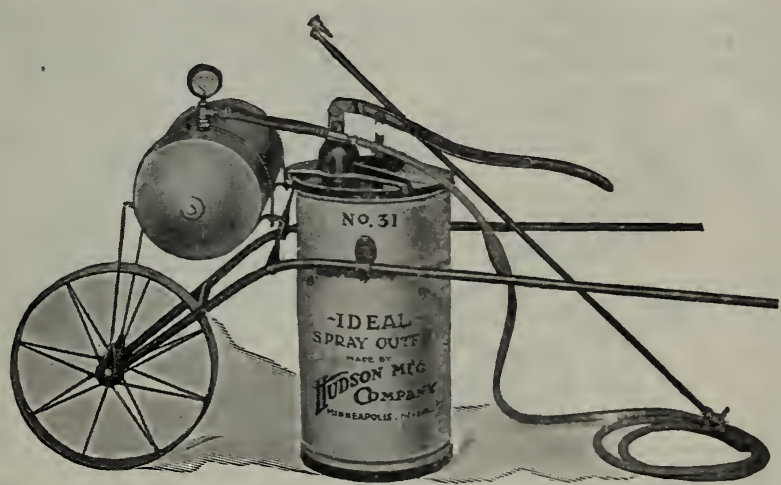

No. 31 IDEAL

This makes a splendid "one-man" outfit. By pumping up about $150 \mathrm{lbs}$. pressure the machine will operate about 5 minutes without further pumping. All parts coming in contact with the liquid are made of brass, the pump being a seamless brass cylinder. The entire machine is made from the best material and varefully tested.

Capacity, 15 gals. Price.............\$48.50

No. 30 IDEAL

This is the same as No. 31, with the exception of not having the air tank and pressure gauge attachments. It is a splendid pump for the price and will do excellent work.

Capacity, 15 gals. Price..............\$31.75

\section{THE STANDARD SPRAY PUMP}

The Standard is the busy man's sprayer. Always ready; saves half the time doing the work. This is, without doubt, the best Spray Pump that has ever been offered to the buying public. It is simple. durable and powerful, and is equally good for field, garden or orchard work. It is made of brass, with two solid brass ball valves; it is pro-
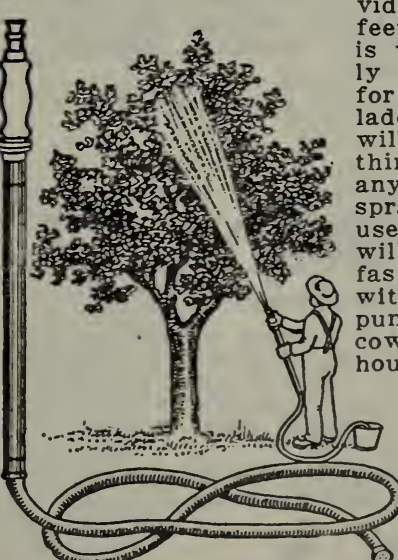
vided with two nozzles, 31 feet of hose and strainer. It is warranted unconditional $1 y$ for five years. No need for unwieldy extension rods, ladders or platforms. It will do the work in onethird the time required by any other sprayer. It will apray a large orchard when used with barrel. One man will do better work and faster work than two men with an ordinary barre It will whitewash cow stables and chicken es, spray cattledip and disinfectants. Owing to the construction of the Standard Spray Pump. the force is sufficient to cover the highest fruit tree and penetrate the thickest foliage reaching the vital parts of the tree. Used with a knapsack potato attachment it will spray a field of potatoes, one row at a time, as fast as 8 man can waik. Everyone who has used this pump or seen it used is an enthusiastic booster for 1t, and we like to sell 1t, for it always makes a satisfled customer of the person who buys it No man with a spot of ground to call his own can afford to be without this pump. The price is reasonable that it is within the reach of all. Weight, 6 pounds

Standard spray Pamp ...............85.50 
By the use of fertilizers you ian
produoe a surplus-Try it

\section{GROW YOUR OWN VEGETABLES}

Cut down your living expenses. You'll be astonished how easy it is to save time, labor, and money, and get bigger and better crops when you un:

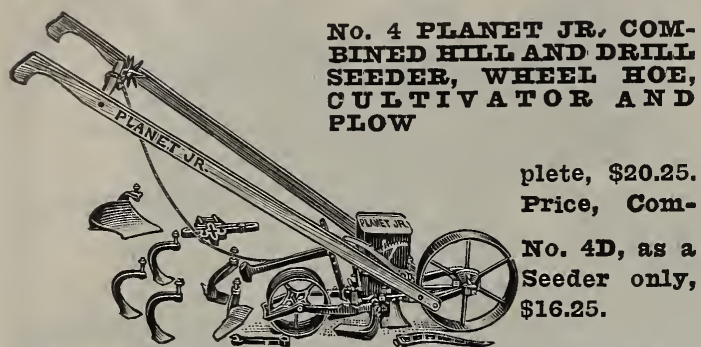

Pays for itself in a single season and lasts a lifetime. Sows all garden seeds (in drills or hills), plows, opens furrows and covers them, hoes and cultivates easily and thoroughly all through the season.

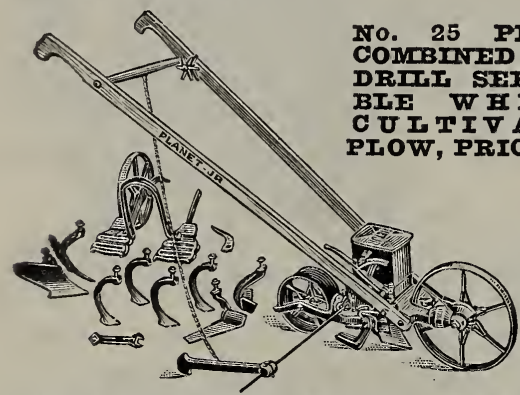

NO. 25 PI.ANET JR. COMIITD FIIT AND W $\mathbf{F}$ 표 I C UITIVATOT AND PIOW, PRICE, \$23.75.

Irames and cultivating attachments as the ran J.. No. 12 Double wheel Foe.

Two acres a day can easily be worked, and when it is done, it will be a better job than several men could have done in the same time with hand hoes.

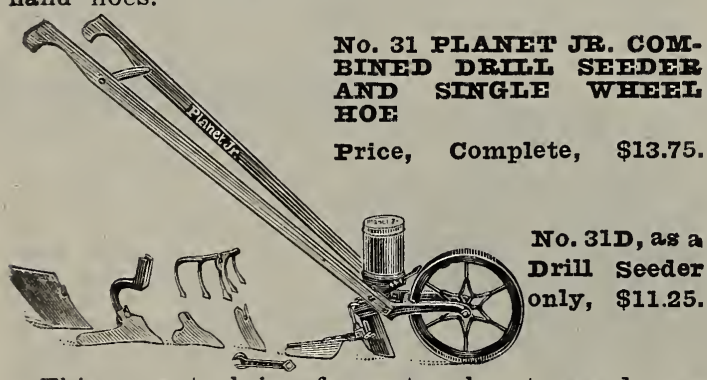

This new tool is of great value to gardeners who have never felt able to own either a seed drill or a wheel hoe. It will sow even a small packet of garden seed with great precision. Quickly changed to a splendid wheel hoe. A special machine for the small gardener.

SO. 33 PI.ANIT JR. SINGIY WHFET HOI

(The No. 31 without Seeder), Price, $\$ 7.50$.

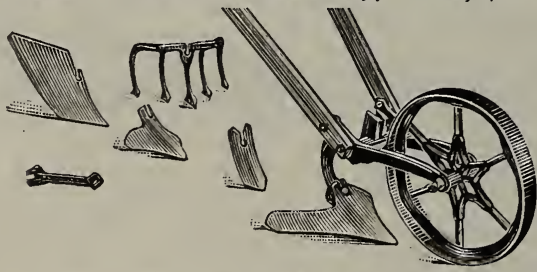

This combination will delight the suburbanite, the srowing boy, women younger or older who will find it a light running wheel hoo that will save them hard work and help much to supply the table with fine vegetables.

Page 90
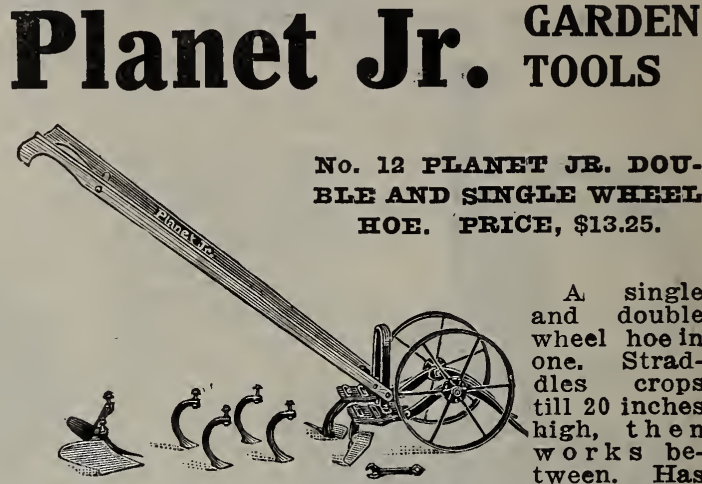

A single and double wheel hoo in one. Straddles crops till 20 inches high, $t h \in n$ works be-

steel frames and 14-inch steel wheels. The greatest hand-cultivating tool in the world.

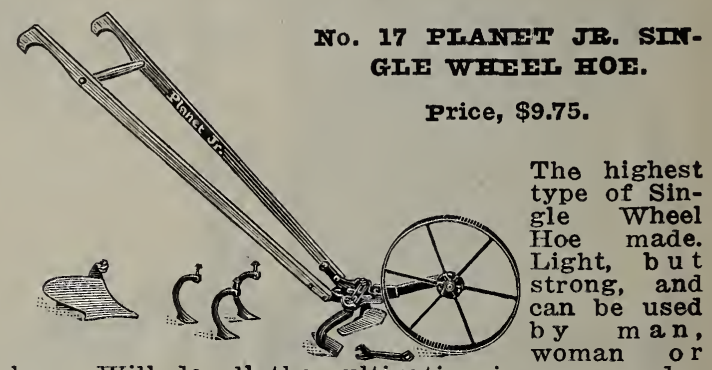

boy. Will do all the cultivation in your garden in the easiest, quickest, and best way.

PIANET JR. STAR PUIVTRIZFR, IFVIIFR AND WFEDFR.

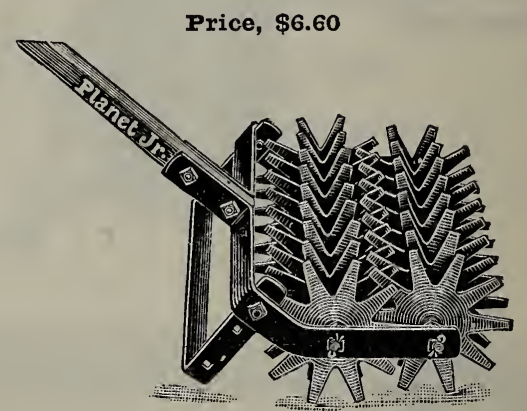

This new tool is especially adapted for preparing the seed bed, and will be found of great value in smoothing and fining the soil surface. The rear blade is $13 \frac{1 / 2}{2}$ inches wide. After the crops are started, it may be used between rows as a weeder or as a crust breaker.

\section{2-PAGE PLANET JR. CATALOGUE FREE}

Describes 70 tools, including Seeders, Wheel Hoes, Horse Hoes, Harrows, Orchard and Beet Cul tivators.

Write Postal for it 


\section{GALVANIZED CHICKEN UTENSILS}

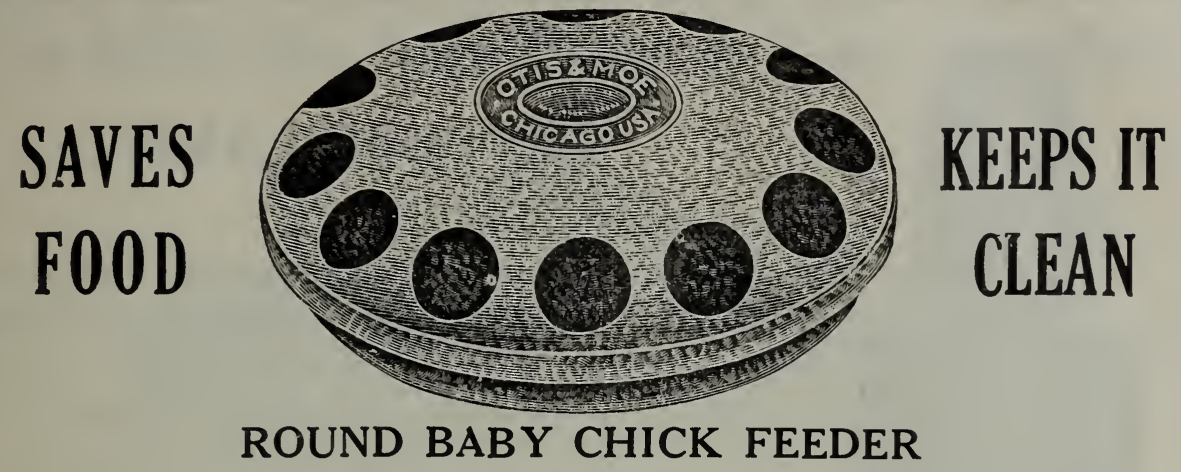

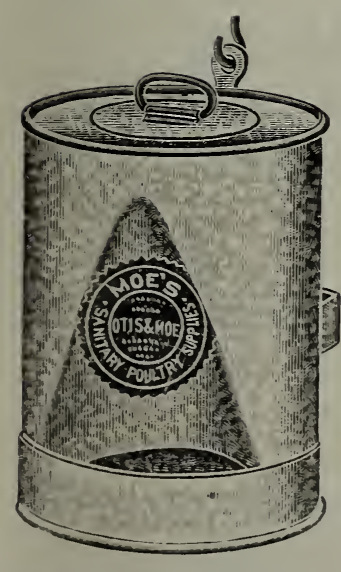

6 in. diameter, each $\ldots \ldots \ldots \ldots \ldots \ldots \ldots .25 c$

8 in. diameter, each $\ldots \ldots \ldots \ldots \ldots \ldots \ldots 40 \mathrm{c}$

\section{WALL DRINK FOUNTAIN}

Style "A" made with removable bottom so that all parts can be easily cleaned. Greatly adding to their sanitation and durability. Easily filled. Manufactured of galvanized iron.

1-gal., capacity, each .....85c

\section{KEEPS CHIX} HEALTHY
Grit and Shell Boxes

3 Compt. Rd. Btm., each ...\$1.15

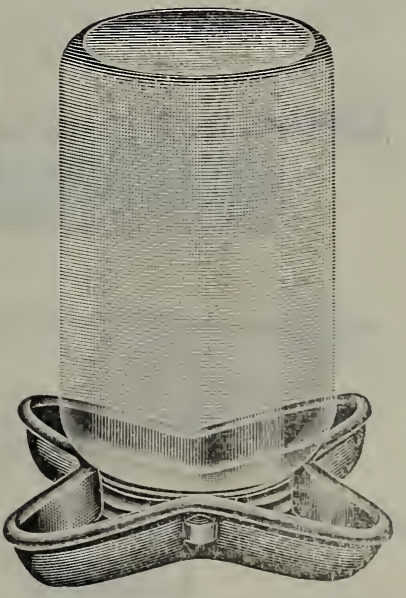

STAR FOUNT and FEEDER

Will fit pint, quart or half-galIon Mason jars. Manufactured of one piece nonrusting metal. No parts to come unsoldered. Little chicks cannot get drowned. Can be used for feed as well as water Without jar, each ........20c 


\section{INCUBATOR AND BROODER SUPPLIES}

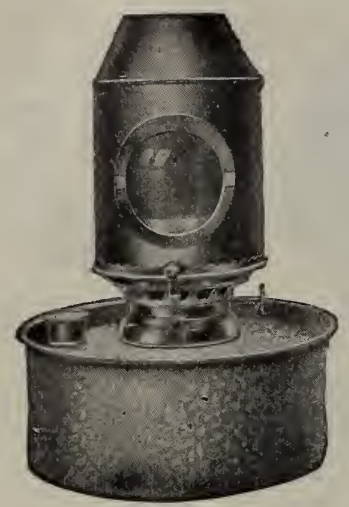

\section{BROODER LAMP}

\section{Improved Safety}

With No. 35 burner with removable gauge, 1-inch wick, $83 / 4$ inches over all. Price, postpaid, lamp complete $\$ 1.75$.

Same with No. 30 burner $1 \frac{1}{2}$ inch wick $\$ 1.75$.

\section{THERMOMETERS}

Queen Incubator Thermometers sent postpaid at our risk $\$ 1.25$.

Tycos Incubator Thermometer a most popular instrument made in Mercury tubes only, each $\$ 1.00$
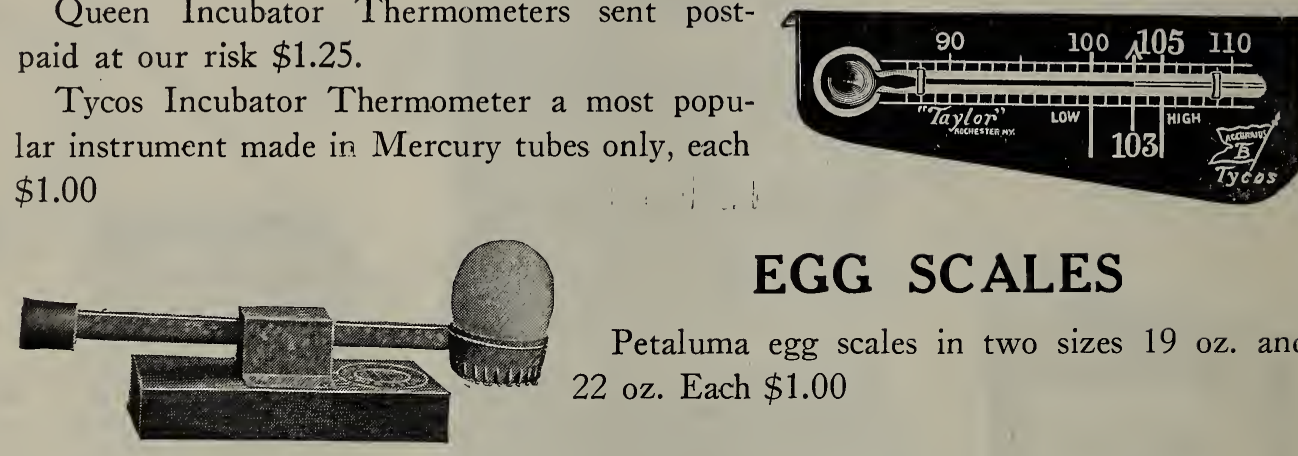

EGG SCALES

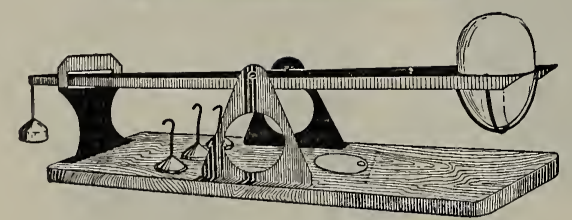

Petaluma egg scales in two sizes 19 oz. and 22 oz. Each $\$ 1.00$

\section{CHICK FEEDERS}

THE McCANDLISH IMPROVED CHICK FEEDER is made of the best quality galvanized sheet metal. Furnished in three lengths $12-20$ and 30 inch. Price $30 \mathrm{c}, 50 \mathrm{c}$ and 75 cents.

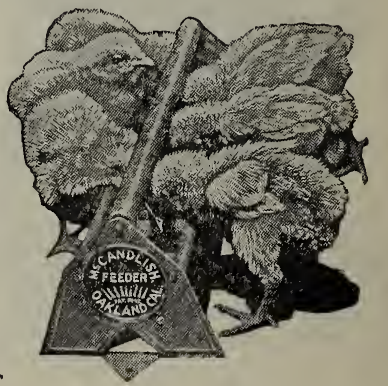

\section{QUEEN HATCHERY}

JAY TODD, Manager 


\section{RAISE YOUR CHICKS IN THE RELIABLE BLUE FLAME HOVER.}

\section{The Reliable Blue Flame Wickless Oil Heated Colony Hover}

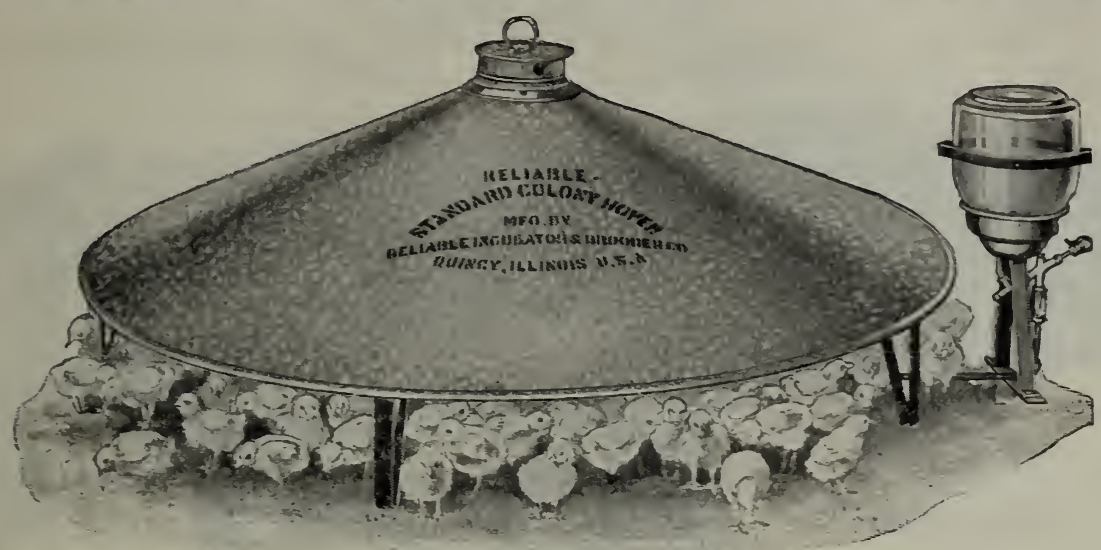

This Hover Represents Our 30 Inch, 42 Inch, and 52 Inch Sizes.

\section{THE MODERN HOVER}

This hover has the same chick capacity as the coal burning brooder.

They are made in four sizes, 18 inch, $30 \mathrm{inch}, 42$ inch and 52 inch hover. A few of the special points on this oil heated hover are as follows:

BURNS COAL OIL.

STEADY BLUE FLAIME.

COMFORTABLE AND EASY TO OPERATE.

ECONOMY OF OPERATION.

NO WICK TO TRIM.

ABUNDANCE OF HEAT.

NO OIL FUIMES.

VISIBLE OIL FEED.

CONVENIENT AND SAFE.

NO COAL, SMOKE OR GAS.

THE FLOW OF OIL IS REGULATED AUTOMATICALLY.

PRICE OF OUR BLUE FLAIME WICKLESS SELF-FEEDING COAL OIL HEATED HOVER COMPLETE

\begin{tabular}{|c|c|c|c|c|c|}
\hline No. & Size & $\begin{array}{c}\text { Weight } \\
\text { Comp. } \\
\text { Hover }\end{array}$ & $\begin{array}{l}\text { Price of } \\
\text { Heater } \\
\text { Only }\end{array}$ & $\begin{array}{l}\text { Price of } \\
\text { Canopy } \\
\text { Only }\end{array}$ & $\begin{array}{r}\text { Price of } \\
\text { Comp. } \\
\text { Heater }\end{array}$ \\
\hline 0 & 30 inch & 40 lbs. & 12.00 & 13.50 & 19.00 \\
\hline 1 & 42 inch & $45 \mathrm{lbs}$ & 13.50 & 10.50 & 21.00 \\
\hline 2 & 52 inch & 55 lbs. & 15.00 & 14.50 & 25.00 \\
\hline & 18 & FO & BY & $2 \Omega$ & ח 0 ח \\
\hline
\end{tabular}

89 Pike Street

\section{QUEEN HATCHERY}

SEATTLE, WASH. 


\section{Queen Incubators}

Queen Incubators are too well known to require any special praise from us. We use them Exclusively, beliere in them implicitly, advertise them that poultrymen may know where to get them and guarantee them to give satisfaction.

We carry the largest stock in the North West and can give you the best service. We carry a full line of parts.
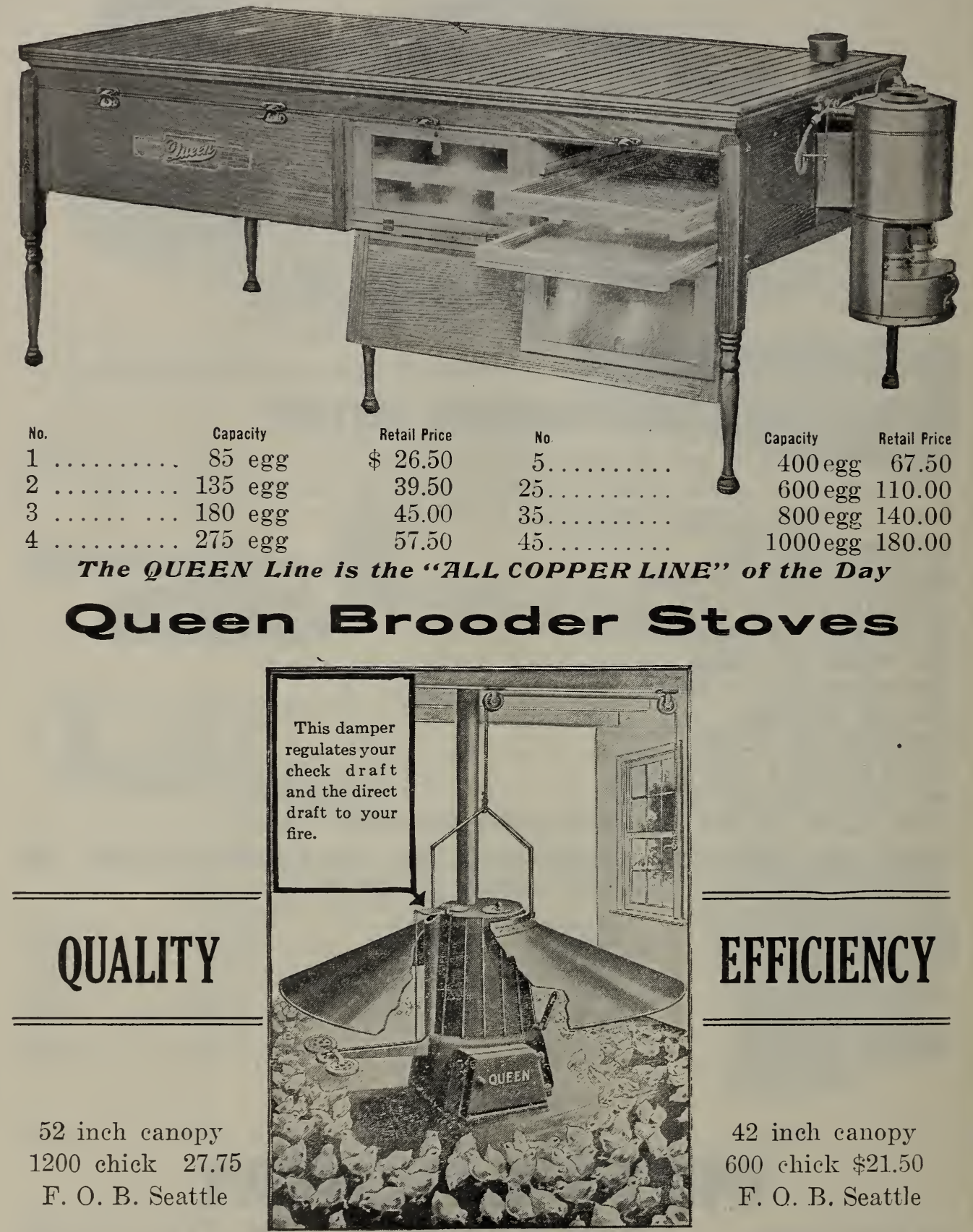

\section{EFFICIENCY}

THE QUEEN STOVE IN OPERATION

42 inch canopy 600 chick $\$ 21.50$

F. O. B. Seattle 


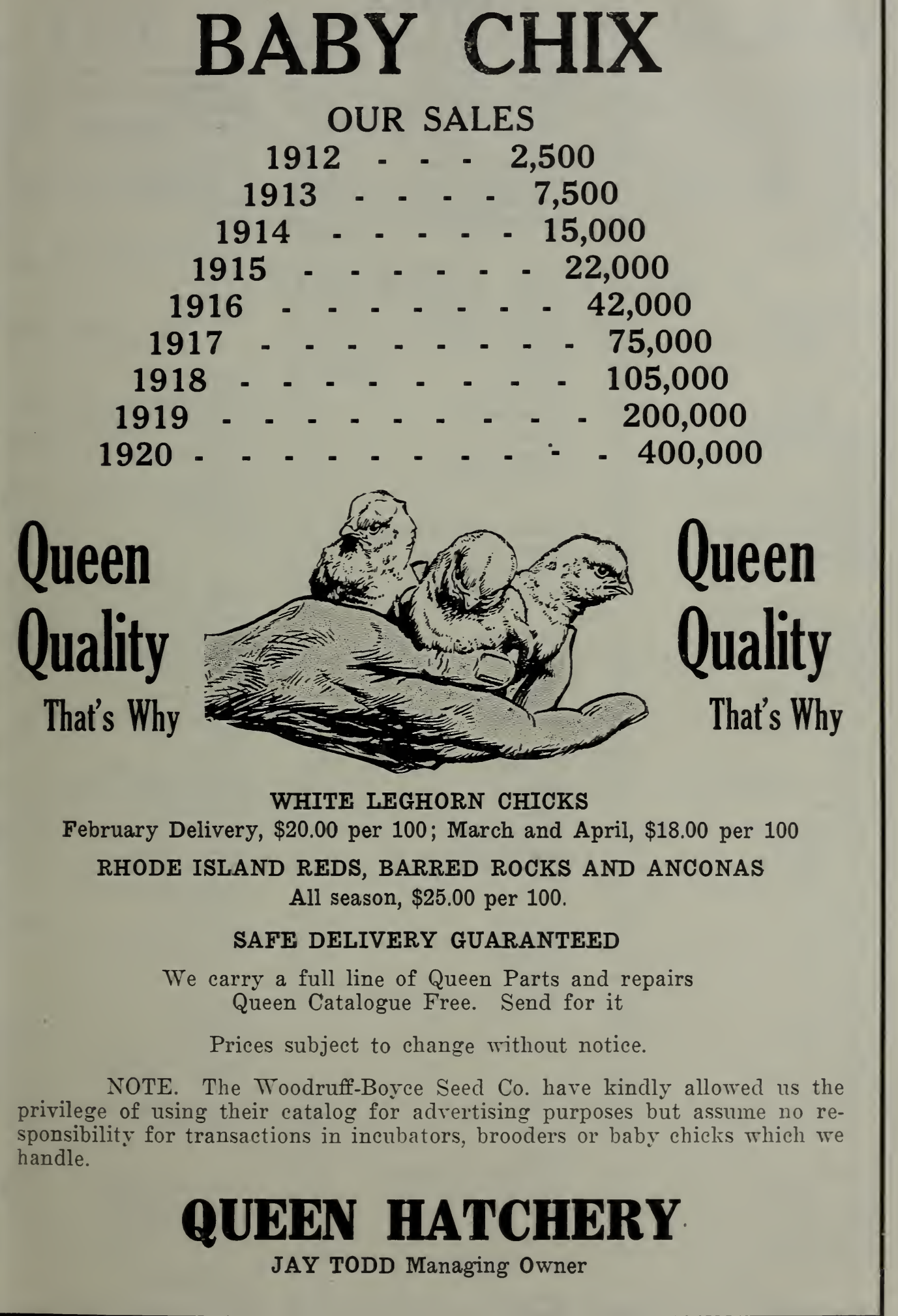


Flower Specials

Artichoke .............11

Asparagus . ........2-11-32

Asparagus, Roots .......11

Asters ...........4.42-60

Apples, Trees ...........77

Crab ….......77

Apricots $\ldots . \ldots \ldots \ldots .680$

Alfalfa ...................

Antirrhinums $\ldots \ldots \ldots \ldots 43$

\section{B}

Beans, Dwarf ........2-13

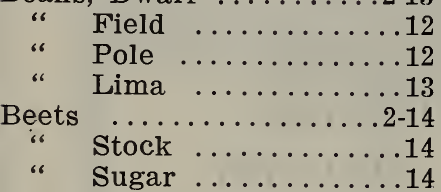

Brussels Sprouts ........15

Broccoli ...............15

Barley ................ 38

Buckwheat ...........38

Brooders .............93

Brooder Supplies .......92

Blackberries ...........80

Black Leaf $40 \ldots \ldots \ldots .87$

Carnations .............45

Chives ............19-32

Cabbage ..............

“ Plants ..........32

Cauliflower .............

“ Plants .........32

Celery $\quad \ldots \ldots \ldots \ldots \ldots \ldots \ldots 4-17$

" Plants ............

Celeriac ................15

Chestnuts ............81

Corn, Sweet …....... 5-18

Field $\ldots \ldots \ldots \ldots \ldots 40$

Corn Salad ............19

Clovers .................35-37

Climbers .........69-72

Cherries …..........78

Cheveril .............19

Currants $\ldots \ldots \ldots \ldots \ldots 80$

Chicks ...............95

Cucumbers ......... 5-6-19

Cut Flowers ….........70

Chicory ...............19

" Witloof .........20

Collards ................ 19

Chrysanthemums $\ldots \ldots \ldots 45$

\section{E}

Endive $\ldots \ldots \ldots \ldots \ldots 20$

" French .........20

Egg Plant ............20

Erfurt $\ldots \ldots \ldots \ldots \ldots \ldots \ldots \ldots$

Evergreens $\ldots \ldots \ldots \ldots \ldots 76$

\section{$\mathbf{F}$}

Field Grasses . . . . . . 35-36 Seeds ........ 38-39-40

Filberts $\ldots \ldots \ldots \ldots \ldots \ldots .61$
Flower Seeds . ....42 to 59

Flower Seeds, Wild......56

Flower Seeds, Treatment

of $\ldots \ldots \ldots \ldots \ldots \ldots$........

Flowers, Plants ......60-61

Fertilizers ........82 to 84

Flowering Shrubs...73 to 75

Formaldehyde ........38

Fruit Trees .........77-78-80

\section{G}

Garden Calendar ..._.....34

Garden Specials .....2 to 10

Garden Tools ...........90

Garlic ................20

Grasses …......35-36-37-49

Gilliflower ..............55

Gooseberries ..........80

Grapes $\ldots \ldots \ldots \ldots \ldots .680$

Grape Dust ............87

Grafting Wax..........87

\section{$\mathrm{H}$}

Hardy Perennials .......71

Herbs ..................11

Horseradish $\ldots \ldots \ldots \ldots . . .32$

House Plants $\ldots \ldots \ldots \ldots 60-61$ I

Incubators $\ldots \ldots \ldots \ldots .94$

Incubator, Supplies.......92

$$
\mathrm{K}
$$

Kale $\ldots \ldots \ldots \ldots \ldots 20$

Kohl Rabi ............20

Lavender ............11

Lettuce .............6.

Leek .................20

Lawn Grass ............37

Loganberries .........81

Lime and Sulphur ......86 $M$

Mangels ............14-39

Melons $\ldots \ldots \ldots \ldots \ldots \ldots 21$

Mustard $\ldots \ldots \ldots \ldots \ldots .20$

Millet ................. 40

Mushroom Spawn ......22

$\mathrm{N}$

Nasturtiums

\section{o}

Onions $\ldots \ldots \ldots \ldots \ldots, \ldots 6-23$

" Sets $\ldots \ldots \ldots \ldots 6-23$

Oats ....................

Okra $\ldots \ldots \ldots \ldots \ldots \ldots \ldots \ldots \ldots 22$

Ornamental Grasses ......71

Ornamental Trees .....75-76

Peas, Sweet ......57-58-59

“" Garden …..... 7-24-25

“ Field ............

Peanuts .............27

Parsley ................

Pepper $\ldots \ldots \ldots \ldots \ldots \ldots 22$

Plants ............32
Parsnips . . . . .

Pumpkins $\ldots \ldots \ldots \ldots \ldots .9 .27$

Potatoes .......... 8-26-27

Plants, Vegetables .....32-33

".. Flower .......60-61

Pansies ................

" Plants $\ldots \ldots \ldots \ldots \ldots 61$

Pears ................

Plums .............. 80

Peaches $\ldots \ldots \ldots \ldots \ldots \ldots . . .60$

Poultry Supplies 91-92-93-94-95

Prunes . . . . . . . . . . . 80

Peonies ..............

Poppies $\ldots \ldots \ldots \ldots \ldots \ldots \ldots \ldots \ldots \ldots 45$

$\mathbf{R}$

Radish ............9-28

Rape $\ldots \ldots \ldots \ldots \ldots \ldots . \ldots . \ldots$

Roses, Culture ........662

Roses .........6. 63 to 69

Raspberries ..........81

Roots $\ldots \ldots \ldots \ldots \ldots \ldots, 82-33$

Rutabaga ............-9-31

Rhubarb …........9-29-33

Rye $\ldots \ldots \ldots \ldots \ldots \ldots . . .69$

\section{S}

Sage $\ldots \ldots \ldots \ldots \ldots \ldots 11-33$

Salsify $\ldots \ldots \ldots \ldots \ldots \ldots \ldots \ldots \ldots \ldots+29$

Sweet Peas ….....57-58-59

Swiss Chard ...........15

Soya Bean ............40

Spinach ...............10-29

Stock Beets ............14

Sugar Beets ...........14

Squash .............. 10-30

Strawberry Plants .......79

Shade Trees ...........75-76

Slug Shot $\ldots \ldots \ldots \ldots \ldots .87$

Sprays ...........85-86-87

Spray, Pumps .........88-89

Spraying Calender ......85

Sudan Grass ............36

Sunflower .............

Shrubs ..............73-74-75

Sweet Potato .........27

Tobacco $\ldots . . \ldots \ldots \ldots . . .31$

Turnips $\quad \ldots \ldots \ldots \ldots \ldots$ 10-30-31

Tomato ............10-31

Tables, Planting ............

Trees, Fruit ….....77-78-80

Trees, Shade and Orna-

mental ............75-76

\section{V}

Vegetable Seeds ....12 to 31 Plants ......32-33

Vetch, Spring ............

\section{W}

Wild Rice ............40

Wheat $\ldots . \ldots \ldots \ldots \ldots \ldots . \cdots 38$

Water Cress .............

Walnuts $\ldots \ldots \ldots \ldots \ldots .61$ 


\section{USE THIS ORDER BLANK}

Woodruff-Boyce Seed Co. give no warranty, express or implied, as to description, quality, productiveness. or any other matter of any seeds, bulbs, plants or trees they send out, and will be in no way responsible for the crop. If the purchaser does not accept seeds on these terms, they are at once to be returned.

\section{WOODRUFF - BOYCE SEED CO.

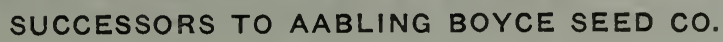

TESTED SEEDS

89 Pike St.

SEATTLE, WASH.

Near Pike Market

Your Name (MR., MISS)

191

Street Address or

No. Rural Delivery

\section{Post Office}

County

State

Forward this Order iy

Station or Express Office

(Only if different from P.O.

\section{Date}

Amount Enclosed

P.O. Order \$

Postage Stamps \$

Draft or Check \$

Coin - $\$$

Our Order No.

No matter how often you write us, always be careful to give full name and address. Write name VERY PLAINLY. State how to forward-whether by freight, express or mail.

\section{SEEDS POST PAID BY MAIL}

We mail and pay postage on all seeds in PACKETS, OLNCES and $1 / 4$ POUNDS purchased from this Catalog. Kindly include postage to cover on other orders.

\begin{tabular}{l|l|l|l|l|l}
\hline QUANTITY & ARTICLES WANTED & PRICE \\
\hline & & & \\
\hline & & & & \\
\hline & & & & \\
\hline & & & & \\
\hline & & & & \\
\hline
\end{tabular}




\section{ORDER FOR SEEDS (Continued)}

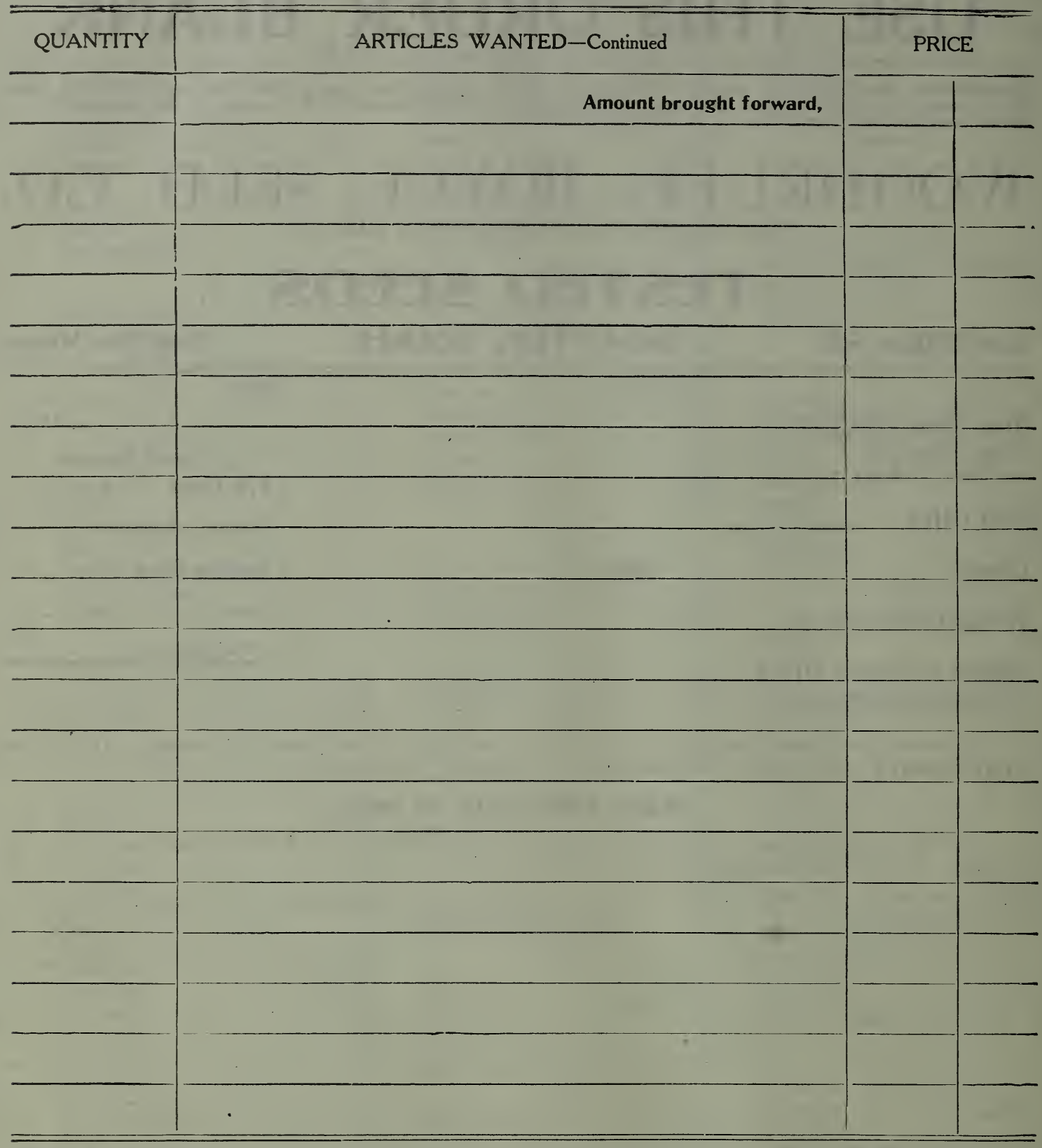

SPECIAL NOTICE: We shall esteem it a great favor if you will give us below, the NAMES and ADDRESSES of any of your friends that are interested in gardening. We wish to send them our CATALOGUE

NAME

POST OFFICE

STATE 


\section{GENUINE \\ HOLLAND BULBS TULIPS HYACINTHS CROCUS \\ DAFFODILS}

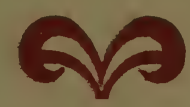

EARLY TULIPS Red, White, Pink, Yellow Per Doz. 35c

DARWIN TULIPS Red Lavender Pink. Purple Per Doz. for

HYACNTHS Red, Pink, White, Blue - Per Doz. \$1.00

\section{CROCUS White, Yellow, blue striped Fer Doz. \$I.}

These are special prices and will remain in effect as long as our present stock lasts. Order early and you will have beautiful blooms early in the spring. 


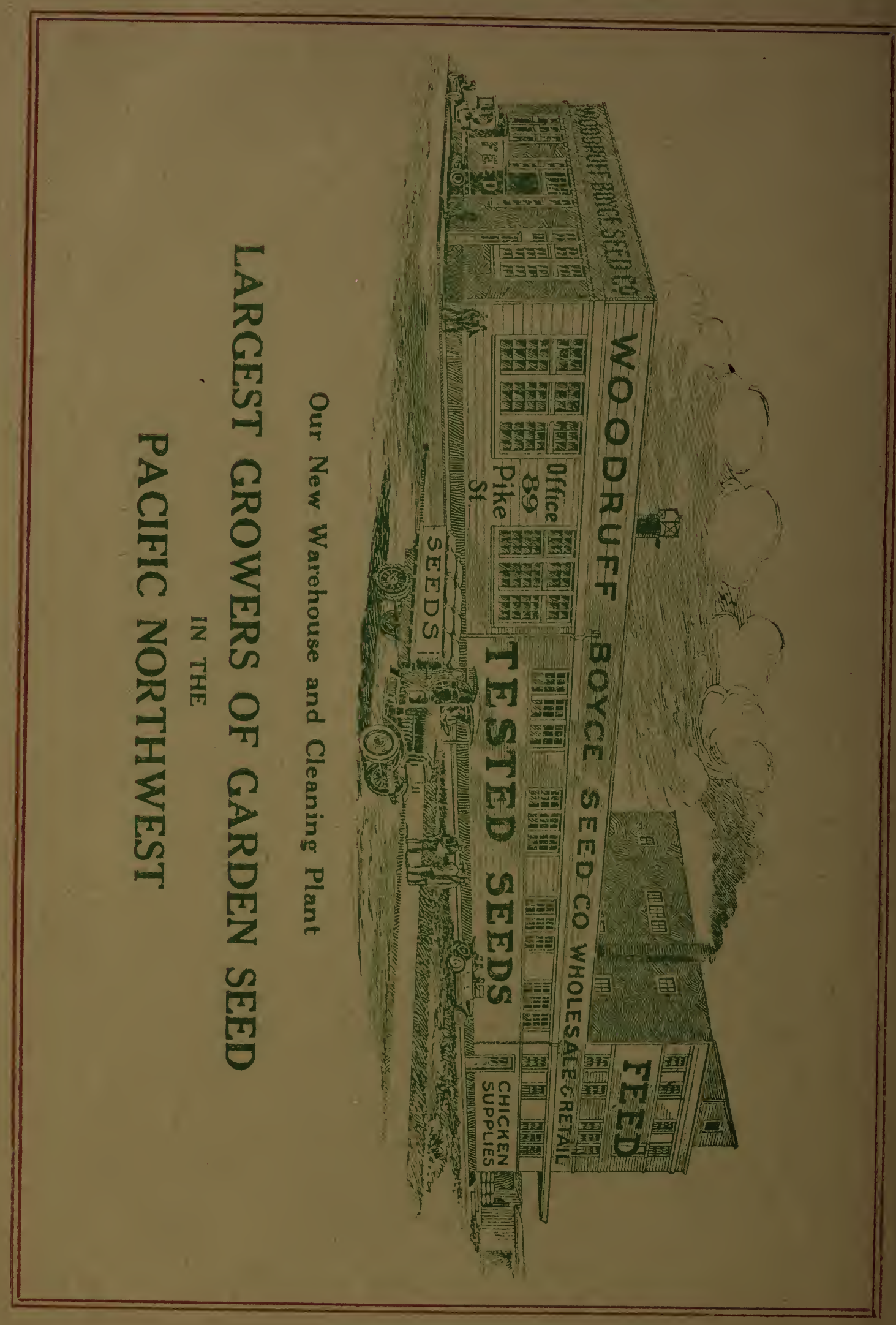

